

$$
\begin{gathered}
\text { G5918 } 7.5 \% \\
\text { CANADA }
\end{gathered}
$$



Digitized by the Internet Archive in 2007 with funding from Microsoft Corporation 
SIXTY YEARS OF PROTECTION

IN CANADA 


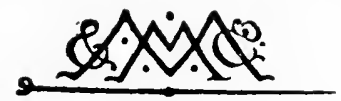

MACMILLAN AND CO., LIMTED

LONDON - BOMBAY - CALCCTTA MELBOURNE

THE MACMILLAN COMPANY

NEW YORK - BOSTON - CHICAGO

ATLANTA - SAN FRANCISCO

THE-JIACMILLAN CO. OF CANADA, LTD.

TORONTO 


\section{SIXTY YEARS}

OF

\section{PROTECTION IN CANADA}

1846-1907

WHERE INDUSTRY LEANS ON THE POLITICIAN

BY

EDWARD PORRITT

SOMETIME LONDON EDITOR 'MANCHESTER EXAMINER'

AUTHOR OF 'THE ENOLISHMAN AT HOME,' 'THE UNREFORMED HOUSE OF COMMONS,'

'A CENTURY AND A HALF OF ENGLISH JOURNALISM IN CANADA'

AND 'IRON AND STEEL BOUNTIES IN CANADA'

'There is no policy more consistent with what we call the Dark Ages of the world than that of protection as a principle. There is no principle more consonant with the advance of human freedom, no principle more in accordance with the great prosperity that prevails in our time, than that of absolute freedom of commerce. -ALEXANDER Mackevzie, Premier of Canada, 1874.78.

'If the National Policy had any basis at all it was that the bread of the people should be taxed. It was an inhuman policy that would make bread and fuel dearer.

'It is alway's easy to increase the tariff, because by so doing you increase the private fortunes of certain individuals.'-Sir WILFRID Lavrier, Premier of Canada.

\section{MACMILLAN AND CO., LIMITED}

ST. MARTIN'S STREET, LONDON 
'The policy of the Laurier Government in refusing to spend money to bring skilled mechanics to Canada has been assailed and attacked by the Manufacturers' Association. . . . The manufacturers frankly claim the right to buy labour at the lowest competitive level. The open shop, with its free competition in the cutting down of wages, is their strongest and most insistent demand, pressed with thoroughly organised force. If they can get Yankees, Italians, Japs, or Chinamen to work cheaper than Canadians they claim the right to turn away their own fellow-citizens. They claim the right to do this on every possible occasion. They are quite within their rights in this respect, provided their workmen are free to employ themselves, and are not taxed for the benefit of any other class.

'Turning to the men with labour to sell and goods to buy, their case is entirely different. When they want to buy the goods which they may be helping to make in the factories they have no such freedom as is enjoyed by the manufacturers in bnying labour. They must pay their protected employers from 10 per cent to 25 per cent and 50 per cent more than the market price. The law which prevents them from taking advantage of a free market, as their employers do in buying labour, cannot be evaded. If they buy foreign goods they must pay to the public treasury, and if they buy domestic they must pay to their protected employers. The tariff law is so designed that the selling or employing class can levy tribute on the buying or work. ing class at every turn. In every one of the multitude of articles that lnake up the year's domestic and personal supplies the employees are made to contribute artificially enhanced prices to their employers. 'Globe, Toronto, September 30, 1907. 


\section{TO THE WITNESS OF MONTREAL}

Some twelve years ago, when I was beginning to take a close and continuous interest in Canadian politics, I inquired of a journalist who is now the doyen of the Press Gallery at Ottawa, what was the daily newspaper from which I could best obtain Canadian news and Canadian political and social opinion. His answer was the Montreal Witness. Since then the Witness has never failed to come to hand in my daily mail-bag. My friend of the Press Gallery was not then, and never has been, connected with the Witness. I am personally unknown either to the editor of the Witness or to a single member of its staff in Montreal ; and without even asking permission, I am dedicating this history of Protection in Canada to the Witness as a tribute of $\mathrm{my}$ admiration of its long and consistent maintenance of the best traditions of English journalism; of my admiration of the fight it has so long and pluckily waged for good municipal government and civic ideals in the city of Montreal, against forces, political, financial, and social, that have seemed at times to have overwhelmed its contemporaries in 


\section{vi PROTECTION IN CANADA}

that city; and finally, as a tribute of my admiration for its fifty years' adherence to Liberalism, and to the principles, political, economic, and ethical which, until the betrayal of 1897 , were vigorously and eloquently advocated by the two men who, by reason of their services of a lifetime, are to-day the most prominent in the Liberal party in the eyes of the people of the Dominion. 


\section{PREFACE}

Although I have travelled much in Canada, and have often stayed there for months at a time, I have never lived in Canada. I am not associated in the slightest degree with any political party there. Had it not been my lot to travel for six or seven weeks with the Tariff Commission in 1905-6, I should have been utterly unknown to a single politician in Canada. My interest in Canadian politics is exclusively that of a student of political science and of industrial and economic development; and it is from this point of view that I have written this history of Sixty Years of Protection in Canada.

I have been outspoken as to political conditions at Ottawa; but nowhere in these pages will there be found a word of disparagement of Canada. I have had too many pleasant days in Canada; and no one can be more confident of its great future than I. It is impossible to travel through Ontario, to stay at 


\section{viii PROTECTION IN CANADA}

Port Arthur and Fort William, and to journey on through Winnipeg, without realising that the twentieth century, as is so often claimed, has great things in store for the Dominion. Canada's possibilities have seldom been overstated, even in these early days of the nation's consciousness and of youthful national assertiveness. Existing political conditions which, it is hoped, may be temporary, are largely accounted for by the fact that neither party in Dominion politics stands to-day for any definite political principles. This lack of political principles and of ideals at Ottawaso discouraging to those who believe in democracy-is, I am convinced, principally due to the hold that the protectionist movement-in which little more than two thousand manufacturers are aggressively engaged-has obtained over both political parties, and especially, since 1897 , over the leaders of what was once the Liberal party of the Dominion.

Four years ago, when my History of the Unreformed House of Commons was published, many reviewers commented with surprise on the fact that such a work could be written in New England. Lest similar surprise should be expressed that a book on Canada could be written outside the Dominion, I may explain that for fifteen years past it has been my good 
fortune to have my home in or near the city of Hartford.

Hartford is famous the world over as the most beautiful city in the United States-as a city of parks, of tree-lined avenues, of spacious open lawns, situated on a majestic river. It is not equally well known as a city of books-as a city with eight public or semipublic libraries. Five of these libraries-the Watkinson Reference Library, the Hartford Public Library, the Library of the Connecticut Historical Society, and the Libraries of Trinity College and of the Theological Seminary-are rich in material for English history-historical manuscript reports, pamphlets, biography, memoirs, letters, and monographs; while as regards the State Library, I know of no library in the United Kingdom outside London and Edinburgh where any phase of British constitutional history, home or colonial, can be pursued with greater ease than at the State House in Hartford. I have used it for many years; but the extent of its treasures came on me as a surprise when I turned to this phase of Canadian history. Canadian Hansards, Dominion and Provincial statutes, Parliamentary papers, and memoirs of Canadian statesmen were all to hand; as were the British Hansards, British statutes 
and treaties; as well as the United States laws, the Congressional Records, and all Government documents from Washington necessary to an understanding of the political and trade relations which have existed between Canada and the United States from the earliest days of the Republic.

For the helpful use of all this material I am much indebted to Mr. George S. Godard, State Librarian, and to Mr. Charles R. Green, his colleague on the State Library staff. I am also indebted for much help to Mr. Avern Pardoe, of the Legislative Library at Toronto; to Dr. James Bain, of the Public Library at Toronto; and to Professor James Mavor, of Toronto University, for the use of many rare pamphlets and much material in manuscript concerning the beginnings of the iron and the woollen industries in Canada.

Hartford, Connecticut, U.S.A., .

November 1907. 


\section{CONTENT'S}

\section{CHAPTER I}

INTRODUCTORY

The Grip of the Protected Interests on the Government and the Press . . . . . 1

\section{CHAPTER II}

The Repeal of the Corn laws and Fiscal Freedom FOR CANADA . . . . . . 43

\section{CHAPTER III}

The Movements for Free Trade and Anjexation 66

\section{CHAPTER IV}

Reciprocity : The Movement for the ElgiNMarcy Treaty 1846-1854 . . . . . 79

\section{CHAPTER V}

Reciprocity: The Abrogation of the Treaty. 1854-1866 . . . . . . . . 119

\section{CHAPTER VI}

Reciprocity : Overtures by CANada SINCE $1866 \quad 159$ $\mathbf{x i}$ 


\section{xii PROTECTION IN CANADA}

\section{CHAPTER VII}

PAGE

The Beginning of the Movement for a National PoLICY

\section{CHAPTER VIII}

The First National Polict Tariffs-1858 to 1870

\section{CHAPTER IX}

Tre National Polict as a Measure of RetaliaTION-1870 то 1874 .

CHAPTER $\mathrm{X}$

The Fight in Parliament and in the ConStituencies for the National Policy. 18741878 . . . . . . . . . 281

\section{CHAPTER XI}

The National Policy in Operation. 1879-1896. The Era of the Red Parlour . . . 315

\section{CHAPTER XII}

The Liberals adopt and extend the National POLICY. 1896-1904 . . . . . 362

\section{CHAPTER XIII}

The Tariff Revision of 1906 . . . . . 421

\section{CHAPTER XIV}

Politics and the Tariff . . . . . 455 


\section{CHAPTER I}

\section{INTRODUCTORY}

THE GRIP OF THE PROTECTED INTERESTS ON THE GOVERNMENT AND THE PRESS

The moment you introduce the protective system you create a class whose interests are essentially different from those of the people at large, and who become the ready contributors to corruption funds, sharing with their masters the plunder which they have been enabled to take from the people.Sir Richard Cartwright.

As the result of the revision of the Dominion tariff which was completed on April.11, 1907, protection to home industries is to-day more firmly entrenched in Canada than in any other country in the Anglo-Saxon world. Protective duties are much higher in the Dingley tariff of 1897 than they are in the Canadian tariff of 1907 ; and in the Dingley Act protection is not tempered, as it is in Canada, by any such expedient as the preferential tariff for Great Britain. But the higher duties in the United States tariff do not invalidate my assertion

1 Cf. Senate Debates, April 11, 1907. 
that protection in Canada is to-day more firmly entrenched in the political system of the Dominion-federal, provincial, and municipalthan in that of any other Anglo-Saxon country. The United States has the highest tariff of the English-speaking world, but there are no federal bounties to industry; the several States bestow upon it no such largesse as is bestowed by the Provinces of Nova Scotia and Ontario; and bonuses, free sites, loans, tax exemptions, and fixed assessments for taxation, such as for thirty years past have been granted by Canadian municipalities to industrial enterprises, are unknown in the United States. They are unknown because in most of the state constitutions there are clauses which directly prohibit bounties or subsidies to industry, as well as other forms of largesse that are to-day so common in Canada.

The Canadian tariff, even when it is borne in mind that the tariff legislation now includes the Acts under which in 1905-6 federal bounties to the amount of more than three million dollars were given to the iron and steel industry, the lead and petroleum industries, ${ }^{1}$ is not a full measure of the protection which is afforded to manufacturing by the Dominion Parliament. It is a measure of the protection given through the agency

1 Iron and steel and steel products, $\$ 2,400,773$; lead, $\$ 90,197$; binder-twine, $\$ 15,079$; and petroleum, $\$ 291,157$ - total for the year ending June $30,1906, \$ 3,088,407$; an increase of $\$ 229,056$ over the bounty payments for the year ending June 30, 1905.Ottawa Correspondence of the Globe, Toronto, August 27, 1906. 
of the customs-houses and of that given direct from the Dominion Treasury. But in addition to the tariff there have been clauses in all the Railway Subsidies Acts since 1900 providing that in the construction and equipment of railways subsidised by the Dominion Government, steel rails, bridge material, and rolling stock made in Canada must be used $;^{1}$ the patent laws were so amended in 1903 as to add to the protection which the tariff is intended to afford to manufacturers; and in 1907 postal rates were revised to exclude advertisements in American periodicals. ${ }^{2}$

Nowhere in the Anglo-Saxon world does industry lean more on the politician than in Canada; and nowhere has protection become a greater menace to good government, central or municipal, or a greater burden to the individual. ${ }^{3}$ The individual burden of protection in Canada is greater than it is in the United States, in spite of the higher duties in the Dingley Act; because notwithstanding the fact that trusts and combinations are numerous in the United States, and their evils admitted, there is infinitely more free trade within the United States than there is in Canada. Manufacturing industries are geo-

${ }^{1}$ Cf. Resolutions $r e$ Railway Subsidies, House of Commons Debates, April 19, 1907.

2 Cf. New Postal Treaty, Globe, Nlay 8, 1907.

3 Cf. The Tariff on Trial, Sir Richard Cartwright (now Minister of Trade and Commerce in the Laurier Government), North Ameriean Review, vol. cl., January to June 1890, pp. 638-646; Honse of Commons Debates (Ottawa), March 22, 1892; and Official Report of Liberal Convention, Ottawa, June 20, 21, 1893, pp. 40-44. 
graphically more evenly distributed over the United States than they are over Canada. The cost of railway communication between centres of manufacture and of distribution is consequently less burdensome; and, moreover, there is much more competition between manufacturers in the United States than there is in Canada. 'Trusts and combinations in Canada control trade much more completely than these organisations have ever been able to do in the United States; and as the result of these conditions, of the fact that there is scarcely a manufacturing industry in Canada that is not dominated by a trust or combine, Canadian manufacturers uniformly live up more closely to the limit of their tariff protection than is feasible in most lines of industry in the United States.

It is an accepted fact at Ottawa, by the Government and by Parliament, that Canadian manufacturers and all other tariff beneficiaries, such as the coal interests of Nova Scotia, exact to the full every cent of protection that the tariff affords them. Just as soon as additional protection is granted, price lists are revised, and prices are advanced. When, in July 1905 , the duties on white leads were increased from five to thirty and thirty-five per cent, the manufacturers of these highly-protected products were so eager to begin levying statutory toll on their customers that telegrams were sent to their commercial travellers instructing them to add these percentages immediately to 
their price lists. I was shown one of these telegrams by a fellow-passenger in a train in New Brunswick. I wish it were practicable to reproduce it in these pages as a contribution to the controversy-always more interesting in a free trade than in a protectionist country -as to who pays the tariff duty. The new tariff of 1906-7 went into operation on November 30, 1906. Within a week the manufacturers of print cloths, who had been given increased protection, advanced prices; and while the Customs Act was still awaiting the royal assent there was a paragraph in the weekly review of the Canadian dry goods trade in the Globe of Toronto, ${ }^{1}$ which illustrates the conditions prevailing at the time the increase was made, and also the extent to which the consumers of cotton goods are coralled by Parliament for the benefit of the three combinations which control the industry in the Dominion. "With regard to the ability of the mills to keep up with the demand," it reads, "wholesalers declare that in the case of Canadian prints and domestic cottons, the situation is growing worse instead of improring, and that, with prices steadily advancing, it is becoming harder than ever to get deliveries."

Were it necessary I could quote numerous other instances of Canadian manufacturers living up to the limit of their protection. I could cite statements that this is uniformly

1 April 20, 1907. 
their practice, made in and out of the House of Commons during the last eighteen months by Mr. H. S. Fielding, who has been Minister of Finance since 1896, and who is primarily responsible for the tariffs of 1897 and 1907 and for the lavish bounty legislation that has been enacted since the Liberal party came into power in 1896. I could also quote many admissions to the same effect by manufacturers who appeared before the Dominion Tariff Commission of 1905-6; who came before Messrs. Fielding, Paterson, and Brodeur to plead for more protection than was accorded them by the tariff of 1897 .

As a result of these conditions-conditions concerning which there is no dispute among men who know the facts-and of the completeness with which the tariff enables most lines of industry to be controlled by trusts and combinations, it is now conceded that living in Canada is no longer cheaper than it is in the United States. ${ }^{1}$ In the early seventies it was the policy of the Government to make Canada a cheap country to live in. ${ }^{2}$ Twenty years ago, even fifteen years ago, the purchasing power of a dollar in Canada was greater than in the United States. 'To-day it is extremely doubtful whether it is equal to

${ }^{1}$ Cf. Gazelte, Montreal, November 29, 1906 ; also letter from R. C. Edwards, late Chairmau of Calgary Advertising Committee, on high cost of living in Alberta, Evening Telegram, Toronto, March 20, 1907 ; and Report of Select Committee of House of Commons on Lumber Combine in the West, Witness, Montreal, April 19, 1907.

${ }_{2}$ Cf. Executive Documents, Washington, 1871, No.94, pp. 24-28. 
that of a dollar on the American side of the boundary line. In most Canadian cities rents are fully as high as they are in cities of a corresponding size in the United States; household supplies are as costly; while as regards furnishings and wearing apparel, if Canada has still any advantage in the price of these, it is limited exclusively to imported British textiles, and Canada owes the advantage to the preferential tariff. I am familiar with economic conditions north and south of the boundary line. I have been familiar with Canadian conditions since 1896, and with those in the United States since 1892; and my conviction, based on long observation and much study, is that a five-pound note can be laid out to better advantage in all lines of manufactures not imported in Boston or Providence than in Toronto or Hamilton.

Nor does the Canadian obtain as good value for money in many lines of domestic manufacture as the American. There is an almost complete absence of competition among manufacturers in Canada, due to the tariff and also to the potent control exercised by trusts, or, where trusts do not exist, to agreements as to selling prices widely common among manufacturers. Thirty-nine trusts or combines were unearthed in a single week at Toronto in November 1905, by the Crown Prosecutor of the Province of Ontario. With only two or three exceptions every one of these trusts controlled manu- 
factures which were protected by the tariff of 1897 ; and at the very time that the Crown Prosecutor was accumulating evidence as to these thirty-nine trusts, ${ }^{1}$ the Tariff Commission, which it was my fortune to be accompanying, was holding its sessions in Toronto, London, Windsor, and Hamilton; sessions at which the manufacturers pressed, usually with success, for increased duties in the tariff on the output of their factories.

Combines and trusts were developed in Canada within a few years of the enactment of the first National Policy tariff in 1879. The cotton industry, in which in 1884 dividends averaged as high as thirty per cent, ${ }^{2}$ first came into complete combination in August $1886 ;^{3}$ and between 1886 and 1906 there was scarcely a manufacturing industry in Ontario and Quebec in which there was any competition, as competition is understood in England and in many lines of industry in the United States.

With a protective tariff, most of whose schedules are framed at the dictation of the protected interests, and with trusts and combinations firmly entrenched, it is plain that there can be little or no competition; and obviously there need be no great effort on the part of manufacturers for excellence, because whether the output is excellent or otherwise,

1 Cf. Globe, April 18, 1907.

2 Cf. House of Commons Debates, February 26, 1884.

${ }^{3}$ Cauadian Annual Register, 1886, p. 314. 
the market for it is secured by the tariff. ${ }^{1}$ Customers are stockaded for the manufacturers. As the representatives of the farmers' associations of Ontario complained to the Tariff Commission at Toronto, London, and Chatham, in November 1905, the consumers are coralled in a stockade or compound erected by Parliament for the manufacturers since 1879, and made additionally secure and difficult to scale by numerous tariff Acts which have been put on the Dominion statute books by both Conservative and Liberal Governments.

In some lines of manufacturc, notably in boots and textiles, it is not denied that the output of Canadian factories has not reached the standard of excellence reached by American manufacturers of the same kind of goods. This inferiority was admitted, and the admission was put on record, in the winter of 1905-6, when the Canadian manufacturers of boots and print cloths appeared before the Tariff Commission at. Montreal and Quebec to ask for more protection-when they preferred requests which were acceded to in the revised tariff of 1907 -in order that they might be enabled to specialise according to the methods of the manufacturers of boots and print cloths

1 Cf. Canada: The New Nation, H. R. Whates; Nationality and Fiscal Freedom, p. 245, where Mr. Whates comments on the "exorbitant profits" which the protected manufacturers "are now" (1906) able to extract from the consumers of their protected shoddy." Mr. Whates's characterisation is far too general and sweeping. I feel that it is unjust to Canadian manufacturers, with whose constant clamour for protection, after my experience with the Tariff Commission, l have no more sympathy than my fricud of Fleet Street days. 
in New England. The Laurier Government readily accepted these pleas for the promotion of specialisation by Canadian manufacturers. They even permitted the shoe manufacturers of Quebec to frame the clause by which these increased duties were levied ; ${ }^{1}$ and the Government, as is its wont, threw the burden of this specialisation on the people of Canada. In 1906 and 1907 the Government was not in a mood to refuse pleas for more protection that were advanced before the 'Tariff Commission, no matter on what pretext. The next general election was ever in mind; and no opportunity could safely be given to the Conservative Opposition at Ottawa, which is even more protectionist than the Laurier Government; although when the Tariff Bill was before the House of Commons the increases in duties and the extension of the iron and steel bounties were defended by Mr. Fielding with as much fervour and zeal for protection as characterised the utterances of M'Kinley or Dingley in 1890 and 1897.

The Liberal Government at Ottawa, notwithstanding the vigorous and continuous onslaughts of the Liberals on the National Policy when they were in opposition from 1878 to 1896 , was from 1905 to 1907 intent on conciliating every interest that has ever had

1 Cf. item 611 in Tariff Bill, introdneed November 29, 1906, and items 611 and $611 a$ in amendments to tariff, House of Commons Debates, February 14, 190 7 ; and reports of Tariff Commission proceedings at Quebec, Transcript, Boston, Mass., December 28 and $29,1906$. 
any protection in the tariff. For consumers the Government had little or no eare. ${ }^{1}$ It acceded to the demands of the shoe manufacturers and the cotton men for more protection in order that they might specialise; overlooking the fact that specialisation is practicable for manufacturers in the United States, because within the confines of their own country they have a population of eighty millions, while specialisation for a country with a population that at most does not exceed six-and-a-half millions, is only possible by such tariff protection as must add seriously to the burden of the consumers.

Even with duties in the Dominion tariff lower than in the United States, protection now costs the individual in Canada more than it does the individual in the United States, for other reasons besides those I have already outlined. In Canada the individual must earry the cost of the Dominion bounties to industries-a cost that in 1907 averaged over fifty cents a year for every man, woman, and ehild in the Dominion. On the individual also is ultimately thrown the cost of the largesse of the Provincial Government to industry, as well as the burden of the bonuses, free sites, tax exemptions and fixed assessments which are bestowed by municipalities on local industrial enterprises.

${ }^{1}$ Cf. Speech from the Throne, House of Commons Debates, April 27, 1907: "The recent revision of the tariff will, it is believed, mest with the general approval of the trade, removing as it does many inequalities heretofore existing." 
The geographical grouping of manufacturing industries in Canada-a few of them in Nova Scotia, but most in the territory which lies between the City of Quebec and the Great Lakes - also necessarily adds to the burden of protection. It adds appreciably to the constantly increasing burden borme by the farming, fishing, and lumbering populations of Nova Scotia, New Brunswick, and Prince Edward Island in the east, and in the stretch of country from the Great Lakes to the Pacific Coast on the west. Sir Richard Cartwright, Minister of Trade and Commerce in the Liberal Governments which have been in power at Ottawa since 1896, seventeen years ago strongly emphasised the geographical burden of protection in the Dominion. "In forming an opinion of the effects of protection in Canada," he wrote in 1890, when he and Messrs. Laurier, Paterson and Mulock and their colleagues of the Front Opposition Bench had not yet betrayed the Liberal party in the constituencies on the question of protection, and while Sir Richard Cartwright was still the hope of the opponents of the National Policy, "it is necessary to remember that Canada is a country which is by nature and circumstances singularly ill-fitted for the successful operation of a protective system; presenting therein a most complete contrast to the United States, in the case of which the conditions are literally and exactly reversed. The most hasty glance 
at the map of North America, and the most superficial acquaintance with the circumstances of the two countries, will suffice to establish this point. Canada is a very thinly-peopled country, extending, it is true, over an immense area and possessing great latent resources; but it is also one in which the several groups of fertile and inhabited or habitable country all lie substantially within the same zone (i.e. the northern part of the north temperate zone); all produce much the same articles; all need to import many things from abroad; all are separated from each other by great tracts of barren and worthless territory; all are rather competitor's than customers of each other; and all would naturally prefer to trade with their neighbour to the south, or with countries across the ocean, than with their own people. To this must be added the fact that the population, besides being so scattered, is so small that . it is quite impossible to carry on many lines of manufacture (except at a ruinous cost to the consumer) in so contracted a market." 1

Canada has added nearly a million and threequarters to her population since $1890,{ }^{2}$ when Sir Richard Cartwright thus dilated on the

1 Sir Richard Cartwright, North American Review, January to June 1890, vol. cl. p. 639 ; see also Sir Wilfrid Laurier's speech, Official Report, National Liberal Convention, 1893, p. 32.

${ }^{2}$ In 1891 the population was 4,833,239; in 1901, 5,371,315 (Canadian Year Book, 1905, p. 2); in 1906, 6,504,000 (Globe, July 11, 1907). 


\section{4 \\ CH.}

unfavourable conditions for protection in the Dominion, when the present Minister of Trade and Commerce wrote the most scathing criticism of protection in Canada that ever appeared in print. But the inflow of population from Great Britain and Continental Europe, for which Canada has been expending seven or eight hundred thousand dollars a year for the last ten years, has not altered for the better the conditions which Sir Richard so forcefully described. It has made them worse. It has made more obvious the burden which protection in Canada imposes on its farming, lumbering, and fishing population; for while this great tide of immigration has gone, and is still going, into the prairie country which lies between Lake Superior and the Rocky Mountains, manufacturing, except for the development of the iron and steel industry in Cape Breton, has become more and more concentrated in the regions of the Provinces of Quebec and Ontario which lie between the Isle of Orleans in the St. Lawrence, and the eastern shores of Lake Huron and Georgian Bay. Not a trickle of this great stream of immigration has found its way into Prince Edward Island, New Brunswick, Nova Scotia, or rural Quebec. Since Confederation the population of the Maritime Provinces has, to say the least, been stationary.

Most of the immigration since 1896 has 
gone westward beyond Ontario. It must go westward; for it is the free Government lands beyond Lake Superior, now chiefly west of Winnipeg, that are attracting immigration from the old World and from the United States. It is these easily acquired virgin lands, together with the aggressive immigration policy of the Ottawa Government, that are adding annually in this first decade of the twentieth century a quarter of a million to the population of the Dominion, and some twelve thousand square miles to the area under cultivation in the graingrowing Provinces of Manitoba, Alberta, and Saskatchewan. It is this vast stream of immigration that is creating at Winnipeg the third largest city in Canada, and building up the greatest railway and distributing centre north of the international boundary line.

There is no manufacturing west of Winnipeg. Farming, lumbering, fishing, mining, and the business of distributing are the occupations west of North Bay. But while conditions as regards the geographical burden of protection are now worse than when Sir $R$. Cartwright described them in 1890, in 1907 it is still the manufacturers of Ontario and Quebec who, through the power conferred on them by Conservative Governments, and continued since 1897 by the Liberals, levy toll to the full statutory limit on this population west of the Lakes; and likewise 
on the rural populations in Ontario and Quebec and the Maritime Provinces of Nora Scotia, New Brunswick, and Prince Edward Islaud. Except as regards the coal industry, which for thirty years has been protected by the tariff, and the iron and steel industry of Nova Scotia, which, besides its protection, has since 1883 been further buttressed by bounties, and except for some small cotton and woollen industries in Nova Scotia and New Brunswick, not one of the Maritime Provinces, and not one of the four provinces west of Ontario, derives any advantage from the tariff.

The Dominion tariff, while it enriches the exploiters of coal lands in Nova Scotia and British Columbia, affords no protection to the lumber industry, to the fishing industry, or to agriculture, either east of Montreal or west of Lake Superior. There are duties in the tariff which the politicians at Ottawa for nearly thirty years past have sought to persuade the farmers are for their protection. These duties were first introduced in the National Policy tariffs which date from 1879 ; and they have been continued in every tariff since then, whether enacted by a Conservative or a Liberal Government. For seventeen years it was the contention of Macdonald and his colleagues in National Policy administrations, that the farmers by patiently carrying the burden of high protective duties were building up a home market, and hastening 
the time when prices for Canadian grain, bacon, eggs, cheese, butter, and apples would no longer be made in Liverpool or Mark Lane.

After nearly thirty years of protection, after protective tariffs, for which both Conservative and Liberal Governments have been responsible, have been in operation for a generation, the argument of Macdonald and the originators of the policy of 1879 has not even yet been abandoned. It was taken up after 1896 by the Liberal leaders - the men who from 1879 to 1896 were foremost in Parliament and in the constituencies, in insisting on the manifest uselessness of protection in the agricultural schedules of the tariff to the great mass of the farmers in the Dominion. These schedules were re-enacted by the Laurier Government. They were re-enacted in the tariff of 1897, the first tariff framed by a Liberal Government since Sir Richard Cartwright revised the tariff in 1876 .

The Laurier Government in 1907 went through the form of increasing the protection supposed to be accorded to the farmers by these agricultural schedules; notwithstanding the fact, brought out again and again before the Tariff Commission of 1905-6, that these schedules had long ceased to hoodwink the general farming community of Canada. They were solemnly reinserted in the new tariff, in spite of the fact that the representatives of the Dominion Grange, the Ontario Farmers' 
Association, and the Manitoba Grain-Growers' Association, first by memorial, and a few days later by deputation to Ottawa, assured the Government that the farmers of Canada were convinced that it was not possible to devise agricultural schedules in the tariff that could do them any service. "We have to-day," read the memorial, which these three organisations of farmers and grain-growers submitted to the Government, "a surplus of one hundred and twenty million dollars of farm produce for export. That surplus is constantly increasing; and so long as these conditions continue the foreign price must control the home price of farm products. While a protective tariff can and does limit our purchasing power, it cannot and does not enhance the price of articles we have to sell." I

Messrs. Fielding and Paterson, and Mr. Fisher, Minister of Agriculture, were the members of the Cabinet to whom this memorial was submitted. Sir R. Cartwright was not of the ministers who received the deputation; for he needed no convincing on this elementary question of economics. The Dominion Grange, the Ontario Farmers' Association, and the Manitoba Grain-Growers' Association were aware that he did not stand in need of conviction; for not one of the Parliamentary leaders of the old Liberal party had striven more strenuously than Sir Richard to free the

1 Memorial re Tariff, Sun, Toronto, November 21, 1906 ; ef. Ottawa Correspondence, Globe, December 19, 1906. 
farming communities of the National Policycreated delusion that protection could be of advantage to the mass of Canadian farmers.

From 1879 to 1896 Sir Richard Cartwright was the Cobden of the Dominion ; and in those days he obviously delighted in being so considered. He was the thorn in the flesh of every National Policy Minister of Finance, from Sir Leonard Tilley to Mr. Foster. Every year from 1880 to 1896 , when the Minister of Finance submitted his Budget statements to the House of Commons, Sir Richard was the Liberal leader whom he had to confront. He was the political economist par excellence of the Liberal party during its long period in opposition; and in the sixteen years from 1880 to 1896 Liberals in and out of Parliament, from the Bay of Fundy on the Atlantic to Vancouver Island on the Pacific, looked to him for relentlessly logical and slashing criticism of the Conservative policy of protection, and in later years - from 1883 onwards - of the associated policy of direct largesse from the Dominion Treasury for the bolstering up of industry.

In those years Sir Richard Cartwright never failed to realise the expectations of the Liberals in and out of Parliament. $\mathrm{He}$ responded to what he knew were the expectations of his political friends. He was generous in his response; for it was his wont to make his onslaughts on the protective system early 
in the debate on the Address in answer to the Speech from the Throne at the opening of each session, as well as to bring out the rod he had in pickle for the National Policy Minister of Finance when the Budget was brought down.

Were the Parliamentary system of Canada like that of England, which, so far as the personnel of the Cabinet is concerned, takes little cognisance of geographical divisions, Sir Richard Cartwright might have been Premier when the Liberals were at last returned to power in 1896. He had earned the office and the distinction. But Canada is essentially Conservative in its political leanings. Its Conservatism goes back to the days of the United Empire Loyalists, the days when every province had its family compact. It was only the scandals associated with the construction and financing of the Canadian Pacific Railway ${ }^{1}$ that gave Mackenzie and the Liberals their lease of power from 1874 to 1878 , and for four years thrust Macdonald into the background.

Early in the nineties, both the Conservative and the Liberal politicians at Ottawa discerned that the constituencies were growing weary of Conservative rule. These signs were as apparent as were the obvious signs of similar weariness in England in the eighteen months which preceded the general election of 1906. Liberal politicians in Ottawa

1 Cf. J. R. Long, Canadian Politics, pp. 161-163. 
welcomed them. But the more astute Liberals realised that reaction against Conservative rule was most manifest in the Province of Quebec; that protection had too strong a hold in urban Ontario to admit of the Liberals making gains in the larger cities of that province; and they foresaw that if they were to succeed at the general election in 1896 the Liberal party must be sure of the Province of Quebec; and for this it was essential that the Liberal party should have a French Canadian leader.

Mr. Laurier had been in Parliament since 1874. He was of the Mackenzie Administration of 1874-78. While the Liberals were in opposition he had developed the qualities which since 1896 have so largely contributed to his success as Premier, and have made him an outstanding figure in the colonial world of the British Empire. While Liberals were still in opposition, and after Mr. Edward Blake, who had succeeded Mackenzie as. leader of the Liberals in 1880, had retired from Canadian politics and gone from Ottawa to Westminster, Mr. Laurier was easily the foremost orator in the Dominion. As years went on he maintained and increased this reputation as much by his speeches in the constituencies as by those which he made from 1878 to 1896 from the Front Opposition Bench in the House of Commons. His grace of style; his tact and demeanour in the 
House of Commons; and above all the apparent sincerity of his convictions concerning protection - the convictions which he developed between the speech of 1876 , when he expressed himself in Parliament in favour of protection, and the National Liberal Convention at Ottawa in 1893-all appealed as much to the Liberals of Ontario, of the Maritime Provinces, and of Manitoba, as they did to the French Canadian Liberals of the Province of Quebec.

It thus easily came about that when $\mathrm{Mr}$. Blake retired in 1892, Mr. Laurier was chosen leader by the unanimous vote of the Parliamentary Liberal caucus at Ottawa-a choice which was enthusiastically ratified by the Liberals in the constituencies at the general election of 1896 , when the Conservatives were defeated, and when for the first time since 1878 a Liberal leader found himself supported by a majority in the Dominion House of Commons.

What might have happened; how different might have been the course of the fiscal history of Canada during the last ten or eleven years, had it been expedient that Sir Richard Cartwright should have succeeded as Liberal leader in 1892, it is now idle to speculate. Sir Richard's admirers, and he still has admirers in spite of the betrayal of Liberalism by the tariffs of 1897 and 1907, like to think that there might have been, by 1907, a tariff for revenue only. They like to think that, instead of a continuance and prodigal extension of 
the bounty system, bounties might have been abolished. It was not, however, his fate to be Premier of the Liberal Government which came into power in 1896 . It was not his fortune to be leader of the Government, which by his exposures of the burden which protection threw on the individual Canadian, and of the corruption that had attended protection between 1879 and 1896, he had been so instrumental in bringing into power. It was not his fortune to be even Minister of Finance, to hold once more the portfolio which he had held when the Liberals were in office from 1874 to 1878. The portfolio of the Minister of Finance had come to be regarded as a prize that must be assigned to a leader from the Maritime Provinces; and in 1896 it went to Mr. Fielding, who was then a newcomer at Ottawa, and who prior to the Liberal Convention of 1893 had been known only as Premier of the Province of Nova Scotia. Much to the relief of the protected interests, who were uneasy after the political overturn in 1896, Sir Richard was made Minister of Trade and Commercea department in which he could have little direct influence on the fiscal policy of the new Government, although, of course, he was of the Cabinet.

With this relegation of Sir Richard, with the new predominance of Mr. Fielding as the financier and economist of the Liberal party, and with the re-enactment of the protective tariff in 1897, and the prompt re-enactment 


\section{PROTECTION IN CANADA cr.}

in the same year of the bounty legislation associated since 1883 with the National Policy, Sir Richard lost his old position as the Cobden of Canadian Liberalism; and in the decade that has intervened since the Liberals came into power, in the quiet seclusion of the Department of Trade and Commerce, he has disappeared as a prominent figure in the national life of the Dominion. He has fallen completely into the background, not only by reason of advancing years, but because as a member of an avowedly protectionist Government, and also as the political head of a Department which is paying out three million dollars annually in bounties, he has ceased to write free trade articles for the North American Review. As a member of the Senate he has now no constituents who expect him to come into their midst with stirring political speeches, like those in which he was accustomed to denounce the National Policy of Conservative Governments. As for his utterances in the Senate, whether in support of the tariff or of bounty legislation, the Dominion seldom hears of these. Most Canadians regard the Senate as a useless institution, ${ }^{1}$ except as adding to the political patronage of the

1 Cf. Address by J. S. Willison at Toronto, Globe, April 30, 1907: "The Senate was the absolute creation of party, existed by the party and for the party. 'So far as I know,' said Mr. Willison, 'it performs no service on earth, except to act as the agent of the party in power. Nothing nearer the abode of everlasting rest can be found this side of the grave. The first issue in civil service reform is the Senate. I am satisfied that if the people could understand the uselessness of that body it would be abolished." 
Government; and they take infinitely less interest in what is said there than Free Churchmen in England take in what goes on in Convocation. Hence the daily newspapers humour their reading constituencies by practically ignoring the speeches that are made in the Senate; or at least, to use a newspaper world phrase, they "bottle them up" in the fewest possible lines.

In 1897, when for the first time for twenty years it fell to the lot of a Liberal Government to revise the tariff, the Government unexpectedly broke new ground. It enacted the preferential tariff for Great Britain, adopting an idea which had been suggested by Sir Charles Tupper in 1878. ${ }^{1}$ But this done, Sir Wilfrid Laurier ignored the speeches in which he had likened the protective system of Canada to the old slavery system of the cotton States of the South. ${ }^{2}$ Sir R. Cartwright dismissed from his mind his article of 1890 in the North American Review, and the scores of scathing attacks which he had made on the National Policy, in and out of Parliament, from 1879 to $1896 .^{3}$ Mr. Fielding like wise turned his back on the conspicuous part which, as Chairman of the Committee on Resolutions, he had taken in the Liberal National Convention at Ottawa in 1893-the Convention at which it was

1 Cf. House of Commons Debates, February 22, 1878.

2 Cf. Speech at Brydon Rink, Winnipeg, Manitoba Free Press, September 3, 1904.

${ }^{3}$ For good examples of these speeches, see Official Report, Liberal Convention, Ottawa, June 1893, pp. 40 to 50. 
declared by two thousand representatives of the Liberal Associations of Canada that "the principle of protection is radically unsound and unjust to the masses of the people." I

The net result of this abandonment in 1897 of the position which the Liberals had so long held with regard to protection was, that neither the privileged manufacturers nor the beneficiaries of the bounty system lost much by the overturn of the National Policy Government in 1896. The exploiters of the ore lands of Belle Isle, Newfoundland, and of the coal of Nova Scotia, who through company-promoting and stock-jobbing have drawn to themselves the lion's share of the ten million dollars that have been dispensed from the Dominion Treasury in iron and steel bounties since $1896,{ }^{2}$ certainly have done as well under a Liberal Government as they could have hoped to do had there been no break in the rule of National Policy Governments. As regards the preferential tariff for Great Britain, and the comparatively slight inroad it made on the protective system of Canada, the woollen industry was the only interest that suffered from this fiscal departure of the Laurier Government in 1897. It appears to have lacked political friends when the tariff was then revised; and in this respect it was obviously at a disadvantage as compared with the cotton

${ }^{1}$ Cf. Official Report, p. 71 ; Federal Elections, 1905; The Issues of the Campaign, p. 4.

2 Cf. House of Commons Debates, February 14, 1907. 
industry, which had been well organised commercially and politically since 1886 . However, the tariff was specially readjusted in the interest of the woollen industry in $1904 ;^{1}$ and between 1897 and April 1907 protection open and avowed, with the most generous largesse for the iron and steel interests, became as much a part of the policy of the Laurier Governments as it had been of the National Policy administrations of which Macdonald was Premier.

Landmarks in the progress away from the principles that the Liberals had so zealously professed during their seventeen years in the wilderness are numerous. Bounties were continued by legislation in 1897 and 1899 ; and the system was greatly extended in 1901 and 1903. In 1900, at the instigation of an American company promoter engaged in the exploitation of the iron ore and timber resources of Western Ontario, ${ }^{2}$ the clause was inserted in the Railway Act which makes it incumbent on companies receiving subsidies from the Federal T'reasury to lay the roads with rails made in Canada. ${ }^{3}$ The surtax on imports from Germany was enacted in $1903 ;^{4}$ and in the same Act, amending the Customs Tariff of 1897, power was given to the Government to impose by order-in-council

1 Cf. 4 Ed. VII. c. 2, sections 16 and 17.

2 Cf. Interview with F. I. Clergue, of Sault Ste Marie, Star, Montreal, April 27, 1901.

3 Cf. 63-64 Vict. c. 8.

${ }^{4} 3$ Ed. VII. c. 15 , sec. 5 . 
a duty of seven dollars a ton on steel rails, for the benefit of rail mills which at this time were being installed at Sydney and Sault Ste Marie. The Dumping Act was passed in $1904 ;^{1}$ and in 1904 also the Canadian Manufacturers' Association achieved its first open victory since 1896 by compelling the Government to revise the tariff. Finally, in 1906-7, came the revision of the tariff, at which the Government dropped all pretence of any regard for the Ottawa Programme of 1893, of any adhesion to the principles enunciated in the speeches of Sir Wilfrid Laurier and Sir R. Cartwright and Mr. Paterson at the Ottawa Convention, and went on record as a protectionist administration.

What influences brought about the betrayal of 1897 ; what influences were responsible for the abandonment of the old hostility of the Liberals to bounties, and what influences brought about the Dumping Act, and the "Made in Canada" amendment to the Railway Act, will be examined in later chapters. All that remains to be said here is that the most striking proof of the extent to which the various privileged interests have captured the Government-of the completeness with which the Liberals in office have turned their backs on every economic and fiscal principle which they advocated in opposition-is to be found in the fact that when the tariff was revised in 1906-7 most manufacturing 
interests-coffin-makers and the stove-makers being the only noteworthy exceptions-were granted additional protection ranging from two-and-a-half to seven-and-a-half per cent, and various new interests were brought under the protection of the tariff.

These new concessions to established industries were made in spite of the fact which was made evident when the Tariff Commission was on its rounds-a fact which was of common knowledge long before the Tariff Commission was organised-that between 1899 and 1905 Canada had been enjoying unexampled prosperity. All the world knew of Canada's great prosperity ; for Canada was participating to the full in the commercial and industrial prosperity of her great neighbour, and in that of the Old Country. But on this question the Tariff Commission started out with an open mind. At Montreal and Quebec, at Toronto, London, Hamilton, and Brantford, all centres of manufacturing in Ontario; and at St. John and Fredericton, New Brunswick; and Halifax and Truro, in Nova Scotia, almost every manufacturer who attended the sessions to petition for more protection on his output, or lower duties on his raw material, was met by the question, "Are you prospering?" and, except in the case of the manufacturers of blankets in Ontario, who at Windsor insisted that the preference was ruining their industry - the answer was invariably in the affirmative. Many manufacturers admitted that their pros- 
perity was without precedent in the industrial history of Canada, and that profits were on a corresponding scale. It was with these statements on the official record of the Tariff Conmission of 1905-6 that the Government increased the protection in the tariff schedules, and thereby the privileged interests of Canada scored a victory that must have surprised the protected interests in the United States; for times were bad when the Dingley Act was passed in 1897, and even in the United States the privileged classes do not agitate nowadays for more protection in an era of prosperity.

The concessions made to the protected interests and to the beneficiaries of the bounty legislation of 1907, taken in conjunction with provincial largesse, and the largesse that is bestowed on industries by the municipalities, all support my assertion at the outset of this chapter that protection and Government stimulus to industry are much more closely interwoven into the political system of Canada than into the political system of any other English-speaking country.

'The interweaving of protection into the political system of Canada has been enormously costly for the people of the Dominion. Through the tariff and through the trusts and combines, which, except in the case of lumber, could not exist if there were no tariff, the money cost alone has been stupendous. Its cost between 1879 and 1893 -after only 
thirteen years of the National Policy - was computed by Sir R. Cartwright in 1893 at " hardly less than a thousand million dollars." "When Germany levied her enormous war indemnity upon France, twenty years ago," continued Sir Richard, "the total sum which the victors dared exact from the vanquished country hardly amounted to the sum which has been levied from you, and taken out of your pockets, for the purpose of entrenching your oppressors in power, and enabling them to defeat the wishes of the people." 1

All over the Dominion Sir R. Cartwright is accepted as an authority on the statistics of trade. Assuming that his estimate of the money cost of protection between 1879 and 1893 is correct, it is safe to assume that the cost in the period between the first National Policy tariff of 1879 and the second Fielding tariff of 1907 , is not less than two thousand million dollars. This estimate must be well within the mark; for Canada since 1893 has had fourteen more years of protection; its population has increased a million and a half ; and the protective system has been made more comprehensive, as may be judged by the fact that while in the National Policy tariff of 1879 the dutiable items numbered three hundred and forty, those in the tariff of 1907 number four hundred and eighty. ${ }^{2}$ In the fourteen years which have intervened since

1 Official Report, Ottawa Convention, 1893, p. 42.

2 Dutiable items, 480 ; free, 231. 
Sir R. Cartwright declared that protection had already cost Canada more than the indemnity levied by Germany on France in 1870, the system of aid from the Provincial Legislatures, such aid as Nova Scotia gave to the promoters of the Dominion Iron and Steel Company, and Ontario bestowed on the similar industrial enterprise at Sault Ste Marie, has come into existence; and in these fourteen years there has been a vast extension of the largesse which the municipalities-especially those of Ontario-have long bestowed on industry.

Nor has the moral cost been less between 1897 and 1907 than it was between 1879 and 1896. In the speech from which I have taken the computation of the money cost up to 1893, Sir R. Cartwright declared that " it must be obvious to every one who will give the slightest attentive consideration to the working of the protective system in this country or elsewhere, that the moment you introduce that system you make legal provision for corruption on a most extensive scale. The moment you introduce the protective system you create a class whose interests are essentially different from those of the people at large, and who become the ready contributors to corruption funds, sharing with their masters the plunder which they have been enabled to take from the people." 1 The Liberal Governments which have been in power since 1896 did not intro-

1 Official Report, Ottawa Convention, 1893, p. 43. 
duce the system which Sir R. Cartwright thus denounced. But since 1896 Liberal Governments have continued it, and greatly extended it. With the exception of tinplate, every new manufacturing industry which has been developed in Canada since 1896 has been brought under the protection of the tariff; and as a result of enactments for which Liberal Governments are responsible, the bounty system has been continued and extended, until to-day it is a charge on the revenue of the Dominion not even dreamed of when a Conservative Government first enacted bounties for the iron and steel industries in 1883.

Even Sir R. Cartwright will not deny that the class of privileged interests which he denounced in 1893-the "class whose interests are essentially different from those of the people at large, and who become the ready contributors to corruption funds," is stronger and more powerful to-day than it was fourteen years ago; nor can any man who knows conditions at Ottawa deny that the privileged class has taken the same attitude towards Liberal Governments that it held towards Conservative Governments between 1879 and 1896. In every country these privileged classes know no politics but the "politics of business." Principles and ideals in politics are regarded as an irridescent dream by tariff and bounty beneficiaries; and since the Liberal Government at Ottawa has come under the influence of these business politicians Liberal- 
ism as a force in Dominion politics has been strangled out of existence.

These privileged classes of the New World support a political party while it is in power so long as it does their bidding. But when the country tires of the party in power, and the constituencies give a majority to the opposition party, the privileged classes immediately transfer their support to the newcomers, without, however, entirely cutting loose from their former allegiance; for it is never the policy of these classes to break with either party. This is what happened at Ottawa in 1896. As soon as the general election was over, the protected interests were the friends of the Liberal Government. With the extension of the protective and bounty system, which has gone on since 1897, the Liberals have had a constantly increasing number of these interested friends ; and the Government has come so completely under the powerful and pervading influence of these exclusively business politicians, that Liberalism as a vital principle in the Dominion Parliament was extinguished before the turn of the new century; although, as the Tariff Commission discovered at Montreal, Toronto, London, Chatham, and Brantford, Liberalism still survives in the eastern townships of Quebec and in Ontario, much as it existed there from the union of the provinces in 1841 to the great betrayal of 1897 .

At Ottawa, although nominally Liberal Governments have now been in office for 
eleven years, Liberalism is only a memory. There is no survival on Parliament Hill-in the Cabinet or in the House of Commons-of the Liberalism that in Ontario dislodged and ended the Family Compact ; fought the battle for a democratic Parliamentary franchise; made an end of the Clergy Reserves and other special privileges of the Episcopal Church; and for years waged the battle of equal privileges for all and special privileges for none.

Liberalism at Ottawa, for the time being, has been completely superseded by politics designed to keep a nominally Liberal Government in office; chiefly, if not exclusively, the politics of business, which are even more rampant at Ottawa to-day than they were at Washington in 1894, when Mr. Cleveland was manfully fighting for the popular cause, as that cause was embodied in the Wilson Actthe Act which was intended to loosen the hold that the protected interests had obtained over the wages and earnings of the people of the United States by the M'Kinley Act of 1890 .

The politics of business were more dominant at Ottawa in the winter of 1906-7 than they were at Washington in 1894; because there was a considerable group of members of the House of Representatives, and a smaller group in the Senate, who were with Mr. Cleveland in the fight against what he himself described as the "communism of pelf." 1 At Ottawa,

1 Cf. President Cleveland's Letter to Mr. Catchings, Washington, August 27, 1894. 
in the winter of 1906-7, Sir Wilfrid Laurier and Mr. Fielding, and all the other members of the Administration, were with the protected interests; and in caucus the rank and file of the so-called Liberal members were kept absolutely in line with the Government. As for the Opposition-an Opposition which, since 1896, has come to stand for nothing but an opportunist policy on the tariff, and is nowadays as useless as a Parliamentary institution as the Senate-the only criticism it offered in the House of Commons on the tariff was that the increases did not make the tariff wall so high that nothing could be got over it; and that the small aperture made in the wall in 1897 by the preferential tariff should have been completely closed until Parliament at Westminster should set up a protective tariff in order to make concessions for the benefit of the lumbermen, the grain-growers and the flour-mill men, the stock-raisers and the pork-packing companies of Canada.

Mr. Fielding piloted the tariff bill through the House of Commons in the spirit of Dingley or M'Kinley. The Premier was significantly silent. Although the bill was before the House of Commons from November 29 until the end of April, when it went to the Senate for its purely formal stages there, it had no outspoken support from the Prime Minister. What adverse criticism there was from the supporters of the Government in the House of Commons was made in caucus behind closed 
doors. There was no serious opposition either to increased duties or to the extension of the bounty system by Liberal members from their seats in the Commons Chamber; while as regards the Liberal press - the daily newspapers in the larger cities between the Atlantic Ocean and the Great Lakes-the only genuine opposition came from the Witness of Montreal. This is the one important daily journal, east of Lake Huron and Georgian Bay, among the newspapers that supported Alexander Mackenzie and Sir Wilfrid Laurier, from Confederation in 1867 to 1896 , which has remained steadfastly loyal to the principles of Liberalism as they were so long enunciated by these Parliamentary leaders, and as they were embodied in the programme of the National Liberal Convention, which the present Minister of Finance was so instrumental in drafting, and which was endorsed by the assembled representatives of Liberal associations from the Atlantic Ocean to the Rocky Mountains. ${ }^{1}$

Liberalism at Ottawa, as I have said, is nowadays only a memory; and it is mostly a memory with the Liberal press of Canada, for most of the Liberal newspapers, which in days gone by reported verbatim the denunciations of protection-Sir Wilfrid Laurier's speeches in which he described protection as slavery, and Sir Richard Cartwright's exposures of the cost in money and political morality-have 1893.

1 British Columbia was not represented at the Convention of 
gone over with the Liberal Government to the politics of business. Some of the Liberal newspapers are now under the proprietory control of men who have accumulated fortunes from their association with the politics of business. The editors of these papers in Halifax, Montreal, Toronto, and Hamilton are not publicists of the school of Howe,. Dougall, and Brown. Conditions are not nearly so favourable for present-day editors in Canada as they were for these men; for where newspapers are controlled, as they are in Halifax, St. John, Montreal, Toronto, and Hamilton, by beneficiaries of the tariff and bounty system, expression of Liberalism, especially as regards the tariff, is necessarily denied. Other Liberal newspapers have gone over to the politics of business because they are controlled by men who are of the Government, or by senators who owe their places to the Government; others because of their large receipts from Government advertising and printing. Some of the Conservative newspapers, like the Opposition at Ottawa, complain that the Government does not go far enough in its adoption and extension of the National Policy. Thus it comes about that to-day the politics of business are dominant in a so-called Liberal Cabinet; that in the House of Commons the caucus has silenced criticism of the protective policy of the Laurier Government from the rank and file of the Liberals; and also that, as regards the tariff, Canada is practically without a free press. 
Isaac Buchanan, who, my reading of the economic and fiscal history of Canada has convinced me, was the father of the National Policy, who certainly was the first man in Canadian politics to adrocate protection in the press, on the platform, and in Parliament, estimated in 1858 that there were in Ontario and Quebec from five to seven thousand men engaged in manufacturing industries who could be protected by a tariff. ${ }^{1}$ The President of the Canadian Manufacturers' Association asserted at Montreal in 1901 that 575,000 men were then employed in manufacturing plants in the Dominion. ${ }^{2}$ I have made no attempt to check either of these figures. Without any assumption that they are correct, I quote them as a measure of the material success that has attended protection in Canada since 1858. They form the credit side of the account.

As for the debit side-the cost in money and in political morality to the people of Canada, I refer my readers back a page or two to Sir R. Cartwright's estimate of 1893 , that up to that time protection had cost more than the indemnity paid by France to Germany in 1870 , and to his description of conditions as they existed in Dominion politics between 1879 and 1893; and I will add as my own comment that since 1894 the money cost must have been much greater than it was between 1879 and 1894, and that as regards political

2 Monetary Times, Toronto November 8, 1901. 
morality there has been no change for the better since 1894. At that time there existed a vigilant Liberal Opposition, as yet unsmirched by the politics of business; and the Liberal press was unshackled. To-day both parties are under the demoralising and corrupting influences of the protective system created by the Conservatives; and the masses of the people, who are the prey of the communism of pelf, have no advocate or champion in Parliament, and few among the more important daily newspapers.

The concomitants of protection that work against wholesome political conditions-that in the United States produced the " fat-frying" process of extracting political campaign contributions, and that between 1879 and 1896 gave Canada the Red Parlour as an extraconstitutional institution-these concomitants are unchanging. They must remain constant as long as they bring advantage to both the politicians and the protected manufacturers. Manufacturing in Canada was on a much larger scale between 1896 and 1907 than between 1879 and 1896. But industries in a protected state never become full grown. The Tariff Cominission of 1905-6 abundantly proved the truth of the assertion as to the determination of industry to lean everlastingly on the politician which was made at the Liberal Convention of 1893. "These industries," said Mr. Gillmor of New Brunswick, "are like the fatted calf, always sucking, and they will never 
get weaned. These infants are never ready to have their protective tariff taken off. You suggest a reduction of tariff to them, and they will look so lean and miserable that you would pity them from the bottom of your heart. But when they feel that the tariff is safe for them, they swell to enormous proportions, and display their carriages and footmen, and their eyes stick out with fatness." 1

With the end of the era of infant industries, and with the capitalisation of aforetime infant industries on a large scale, there has come no change in the attitude of the men behind them towards the Government. They still lean on the politician. The concomitants of protection and of the bounty system are still what they were in $1893,{ }^{2}$ when Sir W. Laurier, in

1 Official Repart, Liberal Convention, 1893, p. 53.

2 Cf. Dominion Election in West Hastings Riding of Ontario; Those Ballot Boxes : Some Decidedly Sensational Evidence-Witness, November 20, 1904 ; Bogus Ballot Boxes in West Hastings (with diagrams to illustrate ballot switching methods)-Witness, November 22, 1904 ; West Hastings Scandal: Reilly admits Guilt -Witness, November 22; Alleged Political Depravity, editorial article-Witness, November 22, 1904; Canada's Voting Frauds, E. W. Thomson, Transcript, Boston, January 11, 1905; The Scandal of the Senate of Canada-News, Toronto, December 14, 1905; Verbatim report of judgments by Chief-Justice Weatherbe and Justice Rnssell at Liverpool, N.S., August 17, 1906, in election case of Cowie $v$. Fielding, which unseated the Minister of Finance as member for Queen's-Shelborne, N.S. - Weekly Herald, Halifax, September 7, 1906 ; Election Scoundrels, editorial article-Witness, August 18; Election Funds, editorial article-News, Toronto, August 20 ; Narrative of Queen's-Shelborne petition and nine other petitions against Liberal members from Nova Scotia arising out of Dominion General Election, 1904, Ottawa Correspondence-News, Toronto, Altgust 29, 1906; Principal Gordon on the Prevailing Corruption in Politics-Queen's University Quarterly, October 1906; A Combine of Grafters, editorial article-Globe, October 3, 1906; House-Cleaning Needed, editorial article-Witness, October 9, 1906 ; Scandals of Session of 1906-News, Toronto, August 10, 
tones no less certain than those of Sir R. Cartwright, denounced the corruption due to the tariff, and from the same platform asserted that "one of the evils of the National Policy and the system of protection has been here, as everywhere else, to lower the moral level of public life"; and further assured the Convention that "if you want to purify the political atmosphere, not a cent is to be levied except what is necessary to carry on the legitimate expenses of the Government economically administered." 1

1906. Newspaper reports of investigations of Committee of Public Accounts, Ottawa, sessions 1906 and 1906-7 ; magisterial investigations of conspiracy charges arising out of London (Ontario) byelection, at which C. S. Hyman, Minister of Public Works, and prominent member of tauners' combine, was returned-evidence given in detail, House of Commons Debates, April 16, 1907; Corruption of Members, editorial article-Witness, November 8, 1906. A Cure for Corruption, editorial article,- "It is to be hoped that they (Toronto Conference on Political and Business Immorality) will give us no such academic cure-all as compulsory voting, but will strive to get at the sources of corruption, which lie not very far from the people who are willing to subscribe to campaign funds with the hope of getting legislative favours "- Star, Montreal, January 9, 1907 ; Report of Conference on Political and Business Immorality at Victoria University, Toronto, January 10, Dr. Burwash, Chancellor of the University, in the chair-Sun, January 16, 1907 ; Professor Leacock, of McGill University, on The Sordid Traffic of a Tolerated Jobbery, at the Empire Clnb, 'Toronto - World, Toronto, March 20, 1907 ; presentment of Grand Jury at Toronto Assizes, re perjury cases arising out of London electionGlobe, Toronto, March 12, 1907 ; Government Officials and Elections, House of Conmons Debates, April 15, 1907 ; affidavit of James Farr, Town Clerk of Goderich, Huron County, Ontario, dated December 8, 1906, re ballot switching in Dominion election of February 21, 1899, for West Riding of County of Huron, cited in full in House of Commons Debates, April 16, 1907 ; Address by George T. Blackstock, K.C., before Canadian Club, Toronto, on Some Tendencies-Globe, April 22, 1907 ; verbatim report of trial of libel suit of R. T. MacIlreith $v$. Herald, Halifax-Herald, ApriI $17,18,19,20,22,1907$.

1 Official Report, Liberal Convention, 1893, p. 36. 


\section{CHAPTER II}

THE REPEAL OF THE CORN LAWS AND FISCAL FREEDOM FOR CANADA

THE consequence of the withdrawal of the protection formerly enjoyed by the colonies has been that they have been left to buy and sell in the markets of the world just as the United States or any other foreign nation.-Sir Francis Hrvcks.

The protectionist movement in Canada is often dated from the general election of 1878 , when Macdonald and the Conservatives, then in opposition, committed themselves to protection. It is sometimes dated from the Cayley Tariff of 1858 , the first tariff in which concessions were made to the Association for the Promotion of Canadian. Industries, the league organised in that year at Toronto by Isaac Buchanan. It actually began on February 6, 1846; and not in Toronto, Montreal, or Hamilton, but in London. It began with the publication by Buchanan-who was in London, when, on January 27, Peel announced in the House of Commons that free trade was henceforward to be the policy of Great Britain - of a letter of protest in the Times, in which he declared that the ending of the old prefer- 
ence in British markets for Canadian grain and lumber must inevitably sever the tie between the British North American colonies and the Mother-country.

Buchanan predicted the loss of the colonies, the bankruptcy of England, the downfall of the monarchy, and the repeal of the Canadian Act of Parliament that gave protection to British manufactures in Quebec and Ontario. He also predicted that the overburdened people of England would soon begin to feel that they were at the expense of defending colonies which were of no use to the Empire for consuming its manufactures or employing its shipping and sailors, and that at a word from England Canada would end the Imperial connection. "Any hint from England of a desire for separation," wrote Buchanan, "will be cheerfully responded to by the people of Canada, who will be writhing under the feeling that England has dishonourably broken the promise of protection to Canadian wheat and lumber made by every Ministry from the timber panic of 1806 downward; and will have got their eyes open to the fact that as there remains no longer any but the slightest bond of interest between Canada and the Mothercountry, no reason can be given why Canadians should risk their lives and property in defending nothing, or should allow Canada to be any longer used as the battlefield of European and American squabbles." 1

1 The Times, February 6, 1846. 
The first plea for the continuance of the preferences, and the first prediction of a National Policy for Canada was thus made by Buchanan, because he happened to be in London when Peel's policy was announced. It thus fell to the publicist, who afterwards became the most vigorous advocate of his day of a National Policy for Canada, to plead for the maintenance of the old statutes which regulated the commercial connection of England and the colonies - the refusal of which immediately led in Canada to the movement for reciprocity with the United States - which resulted in the Elgin-Marcy Treaty of 1854-66-and also to the movement for protection for Canadian industries.

Áberdeen told Delane on December 3, 1845 , that the corn laws were to be repealed. The news was published in the Times on December 4. The announcement was a little premature, for the decision of the Cabinet had not actually been formed; and the manner of the announcement was mainly, if not entirely, a piece of strategy on the part of Aberdeen, who, in the negotiations then pending over the Oregon boundary, wished to soothe the Government at Washington by this indirect intimation of the market which was open for American food stuffs. ${ }^{1}$

The date of the publication of the announce-

1 Laughton, Life and Correspondence of Heury Reeve, i. 175 ; Parker, Sir Robert Peel, iii. 324 ; Stanmore, Memoir of Sidney Herbert, Lord Herbert of Lea, i. 49, 50 . 
ment was determined by the sailing of the American mail, ${ }^{1}$ and the steamer that carried the news for Washington also carried it for Canada. For shipping men and merchants in Philadelphia, New York, Boston, and Portland it was perhaps the most welcome intelligence that ever came westward across the Atlantic between the peace of Paris after the war of the Revolution and the era of ocean cables. It had a contrary significance for the lumbermen of St. John, Halifax, Sydney, and Quebec, and for the grain and flour merchants of Montreal. The news which the Times had given to the world came as a shock to the maritime and commercial interests of the St. Lawrence ports, for it meant a dislocation of trade conditions which had existed since 1806, and which, as regards the grain and flour business, had been of greater value since 1843; and the steamer which carried the newspapers with the reports of Peel's statement of his policy in the House of Commons must have passed the steamer which carried the Earl of Cathcart's urgent appeal for a reconsideration of that part of Peel's scheme which affected British North America.

Cathcart was Governor-General, and in the winter of 1845-46 the seat of government of the United Provinces was at Montreal. Cathcart's case for a continuance of the preferences was that their withdrawal would so seriously cripple commerce that the United Provinces

${ }^{1}$ Cf. Greville Memoirs, part ii. 311-315. 
might be reduced to repudiating the debt guaranteed by the British Government, which they had incurred in constructing the St. Lawrence canals; that under free trade the grain of Ontario would reach England by way of the Erie Canal and New York; that thus the St. Lawrence canals would be rendered comparatively worthless; that the ocean carrying trade out of Montreal would be injured; and that a change in the corn laws which would diminish the price Canadian farmers had been obtaining for their grain since the Act of 1843 would greatly affect the consumption of British manufactures in the provinces. "Even if a relaxation of the system of protection to the colonies is to be adopted," Cathcart pleaded, "it is of infinite consequence that it should not be too sudden. The ruin such a proceeding would cause is incalculable." 1

Communication between Montreal and London in those days was slow; especially in the winter, when navigation was closed and letters had to be sent by Portland, Boston, or New York. But before the end of February Montreal and Toronto were in receipt of newspapers with Peel's speech of January $17,{ }^{2}$ so that the full extent of Peel's proposals was known in Canada six weeks before Gladstone's letter in reply to Cathcart was published in the Canadian press. $^{3}$

1 Cathcart to Gladstone, January 28, 1846.

2 Cf. Globe, March 31, 1846.

3 It was published in the Globe, April 7, 1846. 
Gladstone had joined Peel's administration, December 22, as Secretary of State for the Colonies; and one of his first despatches to Montreal was that of March 3, 1846, in which, while assuring Cathcart that the interests of Canada had not been out of mind in the deliberations of the Cabinet, he reminded the Governor-General that there were matters in which considerations immediately connected with the supply of food for the people of Great Britain and with their employment must be paramount. Gladstone did not share the apprehensions of Cathcart's political advisers that Peel's policy must ruin the trade in corn and flour, for he was confident that in the new competition between Canada and the United States in British markets, Canada had obvious advantages. Taxation in Canada was light; British credit was behind her; there already existed a regular and steady trade between Great Britain and Canada; the tariff of Canada was low, and "on that account powerfully tending to encourage her reciprocal commerce outwards"; and Canada had also some advantages of proximity as compared with the grain-growing States. "She will likewise," continued Gladstone, "have this in her favour, that her corn trade will have become a settled one of some standing, with all its arrangements made and in full operation, while any regular commerce in that article from the United States must be a new creation, and must go through the processes 
attending its self-adjustment to circumstances yet untried."

Canada, Gladstone conceded, had felt a very invigorating influence from the augmented facility of access to British markets which she had enjoyed since the readjustment of the corn laws in her favour in 1843, and this change had perceptibly stimulated the extension of agriculture in Ontario. But he reminded Cathcart that the average prices of wheat during the years 1843-44-45 had been only fifty shillings and tenpence, fifty-one shillings and threepence, and fifty shillings and a penny respectively; and while not presuming to anticipate the ruling prices of wheat after free trade should be established, he thought that they would not exhibit any reduction greatly below these prices; and he was hopeful that grain merchants in Montreal might look forward to a reduction in the cost of conveyance of wheat from Ontario to the St. Lawrence ports.

Gladstone was convinced also that the apprehensions of loss of the Canadian lumbermen were not well founded; that the lumbermen were overlooking the increased demand for timber in England due to the great activity in railway building, which not only in itself called for large supplies of timber, but had the effect of decreasing the cost of conveying timber inland from the ports. These conditions in Great Britain, Gladstone urged, promised a considerable and permanent exten- 
sion of the market for timber. He emphasised the fact that timber from the Baltic did not necessarily come into competition with timber from Canada. "The description of wood which is supplied by the British North American colonies, the yellow pine," he wrote, "is not chiefly to be regarded as competing with the wood of the Baltic, but rather as available for different though concurrent uses. For example, the increase of Baltic timber tending to encourage the construction of new buildings, gives use for Canadian timber for insides." "Her Majesty's Government," he continued, "propose to retain a duty of fifteen shillings a load upon foreign lumber, which I apprehend may be considered as on the average nearly covering the difference between freights from the Baltic and from British North America to the United Kingdom ; and not only are they free from apprebension that the proposed remission of ten shillings per load on foreign timber and twelve shillings on foreign deals will cause a contraction of the trade from British North America, but they are sanguine that the trade will nevertheless continue to extend itself." Finally, Gladstone recalled the fact that the reduction of the duty on colonial lumber to a nominal amount in 1842-one shilling a load on timber and deals, as compared with fifty-five shillings before and twenty-five shillings after 1843 on lumber and deals from non-British sources of supply -had involved the sacrifice of a considerable 
revenue. But it was done to convince Canada of the goodwill of the British Government towards her; and in view of these concessions of 1842 Gladstone appealed to Canada for support and co-operation in the policy that Peel was adopting for the benefit of the Mother-country. ${ }^{1}$

Great depression prevailed at the commercial centres of Quebec and Ontario in the winter of 1845-46. ${ }^{2}$ Local commercial conditions consequently aggravated the unrest and the apprehensions as to the disastrous effects that might follow from the radical change in the fiscal policy of the United Kingdom. Among men engaged in trade at Montreal there was a feeling that a blow was about to be struck that nothing could remedy. ${ }^{3}$

Full details of Peel's proposals reached Canada at the end of February. The Legislature was not to convene until March 20, but the Board of Trade of Montreal (what in England would be termed the Chamber of Commerce) was not disposed to await the action of the Legislature. Quebec was then the great lumber port of the St. Lawrence. Grain and flour were shipped from Montreal. It was with these shipments that most of the members of the Board of Trade were concerned;

I Cf. Gladstone to Catheart, March 3, 1846; Dalhousie's Speech on the Customs Duties Bill, House of Lords, Hansard, series iii. vol. lxxxvii. pp. $16,17$.

2 Globe, November 9, 1852.

3 Cf. Legislative Reports, Globe, November 9, 1852. 
CH.

and it was to appeal for a continuance of the preferences on these that the Board of Trade, on February 25, drew up its memorial to the Secretary of State for the Colonies. In this Gladstone was informed that under the conditions proposed in Peel's measure Canadian grain shippers could not compete with those of the United States; that a protection of even a shilling a quarter, small as it might appear, would aid in securing to Canada a share of the grain trade of the Western States, to the encouragement of British shipping; and that unless some protection was given to produce imported from the United States the St. Lawrence canals, instead of being a source of revenue, would become a burden on the province. For these reasons the Board of Trade petitioned that so much of the Imperial Act of $1842^{1}$ as imposed a duty of three shillings a barrel on foreign flour imported into Canada be repealed $;^{2}$ and that grain, flour, and meal from Canada, from whatever source, be allowed to be imported into the United Kingdom duty free, and not charged with a registration fee of one shilling a quarter or barrel, as proposed in the bill which was at this time before Parliament at Westminster. ${ }^{3}$

The Board of Trade at Quebec took similar action on March 25. In the Quebec petition attention was called to the operation of the

1 Cf. 5 \& 6 Vict. c. 49. 2 Cf. $9 \& 10$ Vict. c. 94. 3 Colonial Correspondence, 1846. 
draw-back law of the United States of 1845 , which allowed a remission of duties on goods arriving at Portland, Boston, New York, Philadelphia, and other American ports for trans-shipment to Canada, and to a bill then pending at Washington according Canadian goods free entry for re-export from United States ports. It was pointed out that the law of 1845 had greatly increased importations into Canada viô the Atlantic ports of the United States, and had decreased trade at the St. Lawrence ports in tea, sugar, fruits, and wine. The petitioners therefore urged that the Imperial duties under the Act of 1842 on flour and provisions imported into Canada by inland navigation should be repealed; and that all such goods from the United States conveycd over the St. Lawrence route to a Canadian port should acquire a colonial character, and be admitted into the United Kingdom on the same terms as produce from Canada, and that Imperial duties on all importations into Canada by sea be also repealed.

As to the lumber business, in which Quebec was more concerned than Montreal, it was complained in this petition of March 25 that if the differential duties existing in the United Kingdom in 1846 were reduced from twentyfive shillings to fifteen shillings a load, such a reduction would be equivalent to five shillings a load in favour of timber from the Baltic, as the difference in shipment charges to the 
United Kingdom between British North American ports and Baltic ports was twenty shillings a load. It was pleaded that the timber-carrying trade over-sea was of great importance to the Empire as a nursery of British seamen; and on this ground it was urged that instead of the duties on Baltic timber being reduced five shillings in 1847 and five shillings in 1848, as proposed in the bill before the Imperial Parliament, the reductions should be two-and-sixpence at each date, and that the reductions on sawn lumber from non-British sources of supply should be lessened proportionately. ${ }^{1}$ With respect to the political effect of the fiscal changes, and especially as regarded the attitude of Canadians towards Great Britain, it was urged in the Quebec petition that the ending of the preferences would "gradually, silently, and imperceptibly" wean Canadians from their true allegiance to Great Britain, and bias their minds in favour of a closer connection with the United States, through which the transport of their merchandise and produce was encouraged, and a consequent more frequent intercourse with the people of the United States brought about. ${ }^{2}$

At Toronto the Board of Trade also protested against the legislation at Westminster. There, as at Montreal, there was much un-

1 Colonial Office Correspondence, 1846.

2 Colonial Correspondence, 1846; cf. Hansard, series iii. vol. Ixxxvi. p. 562. 
easiness as to what would become of the public debt of the province-which in 1846 stood at three millions sterling - a large part of it incurred in building the Welland and St. Lawrence canals. "The proposed measure of Sir Robert Peel," said George S. Workman, who was President of the Board of Trade in 1846, "has taken many of the community with surprise. We are in the same condition as a man suddenly precipitated from a lofty eminence. We are labouring under concussion of the brain." Another member of the Board suggested that Great Britain should at least make Canada a present of the canals and other public works. "This," he said, having in mind the fact that the British Government had guaranteed the loan, "would be no more than justice, after the Home Government has deprived us of the power of obtaining a protected revenue," ${ }^{1}$ - the revenue which Canada had derived on imports from the United States transported over the St. Lawrence waterways for shipment from Montreal to the United Kingdom.

The agitation at Quebec, Montreal, and Toronto went on between the date when the statement in the Times of December 4, 1845, was published in the newspapers of these cities, and the assembling of the Legislature on March 20, 1846. The boards of trade were the centres of most of the agitation; for the lumbermen, merchants, millers, and

1 Cf. Hansard, series iii. vol. Ixxxvi. p. 555. 
shipping men who had derived advantage from the preferences, were of these permanent commercial organisations, and through them had a ready channel of communication with the Colonial and British Governments.

It is not possible to trace that the farmers of Ontario, who raised the grain that had been exported to the United Kingdom under the old preference, or the men who went into the lumber camps of Ontario and Quebec to hew the timber exported from the port of Quebec, took any part in these protests or in the protest which at a later date was made by the Legislature of the provinces. Much of the flour that had gone to British ports was from grain grown in Ohio and Illinois. Between 1843 and 1846 a large proportion of the grain that had been exported from Canada was from south of the boundary line; and when the statistics of this transatlantic grain and flour trade between 1830 and 1846 are examined, ${ }^{1}$ it seems doubtful whether much advantage had accrued to the farmers of Ontario from the preference.

It is not necessary even to summarise all the replies from Downing Street to these memorials from the boards of trade. Gladstone's answer to that from Montreal will suffice. In a despatch dated April 1, 1846, the Secretary for the Colonies, who had the more leisure for this important correspondence

${ }^{1}$ Cf. Hansard, series iii. vol. lxix. p. 991. 
as he was from December 1845 to July 1846 without a seat in the House of Commons, reminded Cathcart that in his despatch of March 3 he had indicated the policy which the Government intended to pursue. "But," he continued, "as it is necessary that I should return a direct answer to the memorial which I have now before me, I have to instruct your lordship to acquaint the memorialists that if Parliament shall adopt the changes in the corn laws of this country which have been submitted to their deliberations, ${ }^{1} \mathrm{Her}$ Majesty's Government will regard the local duty of three shillings on corn as an exclusively provincial question; and if the Legislature of Canada shall think it expedient to pass an Act for the repeal of that duty, Her Majesty will not be advised to disallow that measure." With respect to the plea of the memorialists at Montreal - a plea that was also embodied in the Quebec memorialthat grain, flour, and meal of American origin should be admitted free of all duty at British ports when exported from Canada, Gladstone intimated to Cathcart that the Government regretted that they did not think it " entirely compatible with the spirit of the commercial treaties between Great Britain and other Powers to revive the system, ${ }^{2}$ which once prevailed, of allowing the introduction of

1 The bill had been read a second time on March 22, and was at committee stage in the House of Commons until May 8.

${ }^{2}$ Cf. Hansard, series iii. vol. lxvii. pp. 1319, 1320. 
goods from colonies at colonial duties with reference not to their origin, but solely to their place of export."

In the speech from the throne at the opening of the Legislature on March 20, 1846, Cathcart briefly announced the changes that were making in England, and informed the Legislature of his appeal of January 28, to Downing Street, for a due consideration of the effect that any contemplated alterations might have on the interests of Canada. No action was taken by the Legislature on the 20th, although there was a brief discussion of the new departure in England in the House of Assembly, on the motion for the address in reply to the speech from the throne. ${ }^{2}$ But on the 26th the House of Assembly, on the motion of Cayley, who was Inspector-General, ${ }^{3}$ agreed to an address to the Queen in which the Commons of Canada reiterated Cathcart's plea that the claims of the province be not overlooked, and advanced a new and more definite plea. The Commons petitioned that Her Majesty be graciously pleased to recommend to Parliament at Westminster that "wheat-flour, wheat, peas, and all grain and

1 Colonial Office Correspondence, 1846.

2 Cf. Globe, March 31, 1846.

3 The office of Inspector-General was created by a British statute. It antedated the union of the Provinces in 1841, when it was the duty of the Inspector-General to supervise the collection of import duties at the St. Lawrence ports, and apportion them between Upper and Lower Canada. In 1859 the Inspector General became Minister of Finance. Sir Alexander T. Galt was the first to hold the new office, and the change in termiuology is in itself a landmark in the history of Canada's political and fiscal freedom. 
meal from any description of grain and pulse, imported into the United Kingdom, might be admitted on the payment of the smallest possible specific duty, not exceeding a penny the quarter."

Gladstone, in the third of his answers to appeals for a continuance of preferences-an answer dated April 18-assured the Commons that it was Her Majesty's desire and intention to pay every regard to the commercial interests of Canada-"even in the consideration of measures which must be regarded as mainly and properly appertaining to the internal condition of this country-which may be compatible with justice to other classes of Her Majesty's subjects." "Her Majesty's Government," he proceeded, "are of opinion that the reduction of the duty on Canadian wheat from one shilling to one penny would fail to have the effect which the Assembly have, it is probable, anticipated and desired. Use and convention, rather than abstract principle, have established the rule that in the customs laws of this country one shilling per quarter shall be regarded as the standard of a nominal or register duty upon corn. To reduce the charge upon foreign corn to a rate corresponding with this description, Her Majesty's Government stands pledged to Parliament; and if Her Majesty's Government were to concede the request which is preferred, the effect would not be the establishment of a

1 Colonial Correspondence, 1846 ; cf. Globe, April 7, 1846. 
minute preference amounting to elevenpence per quarter in favour of Canadian grain as against the foreign article, but it would without doubt be this-that the same reduction would be applied by Parliament to foreign grain also; and an entire equality between the two would thus be still maintained. For this reason Her Majesty's Government are of opinion that it would not be expedient to propose to Parliament the alteration which it is the object of the address to recommend." 1

Five distinct pleas were made by Canada to the British Government in these early months of 1846, when the fiscal system of the Empire was being recast. One originated with the Legislature of Canada; four with the Boards of Trade of Montreal and Quebec. These five pleas were (1) that the preference should be continued on lumber from British North America; (2) that a nominal registry fee of only one penny should be charged at British ports on grain and flour from Canada, as against the registry fee of one shilling on these products from foreign ports; (3) that grain and flour from the United States, reexported from Canada to the United Kingdom, should be treated as colonial produce; (4) that the British Act of 1842 imposing duties on American grain and flour imported into Canada should be repealed; and (5) - the plea of the Quebec Board of Trade-that Imperial

1 Colonial Office Correspondence, 1846. 
duties on all over-sea importations into Canada ${ }^{1}$ should cease.

Only the last two of these pleas were . acceded to. The British Government had no option but to accede to these, as the new fiscal system of necessity ended the system established in Canada by the Act of 1842; and with the great changes made in the United Kingdom it would not have been practicable or expedient to fetter a colony with representative institutions, and in which responsible government was gradually being secured, by legislation enacted at Westminster in the spirit of the British Possessions Acts.

The year of the adoption of free trade in England saw also the beginning of the era of fiscal freedom for Canada; for in 1846 there was an amending Act (9 and 10 Vict. c. 94 ), which gave to the British North American colonies power, with the assent of the sovereign in council, to reduce or repeal all or any of the duties in the British Possessions Acts. In a word, with the adoption of free trade in England, power was given by Parliament at Westminster to the Legislatures of British North America to pass such enactments with regard to duties and trade as might be found suited to the needs and geographical position of the several provinces, and also such enactments as would enable the provinces to meet on terms of friendly

${ }^{1}$ Under the British Possessions Acts of 1833 and 1845, 3 \& 4 W. IV. c. $39 ; 8 \& 9$ Vict. c. 9 . 
reciprocity any advances which the Government of the United States might be disposed to make for the mutual encouragement of industry and trade, and for the development - undisturbed by artificial influences-of the resources of each country. ${ }^{1}$

Canadian fiscal freedom, so far as it is governed by enactments made at Westminster, dates from 1846 ; although it was not until forty years after the adoption of free trade in England that Canada was permitted to enact her tariffs without remonstrance from the Colonial Office, or without criticism by chambers of commerce in England and Scotland, or in both Houses of Parliament. The price that Canada unwillingly paid for this freedom was the denial of three of the five pleas which in 1846 she so strongly urged on the Imperial Government. Under the new fiscal system of the United Kingdom, as it was developed after 1846, gradually diminishing preferences were retained for a while on Canadian lumber. But the preferences for grain and flour which began in $1828^{2}$ came to an end in 1846 . The old navigation laws, which had been of much advantage to shipowners and shipbuilders of Quebec, Nova Scotia, and New Brunswick, were repealed in $1849 ;^{3}$ and by

${ }^{1}$ Cf. Memorandum of Inspector-General Cayley, March 24, 1847.

2 Cf. Hansard, series iii. vol. lxix. p. 704.

8 Cf. Petition to Her Majesty from St. John, New Brunswick, Colonial Correspondence, 1848 ; Buchanan, The Country and the Empire, p. 245. 
$1860^{1}$ not a vestige was left of the preferences which Canadian products had enjoyed at British ports since the Act of $1806,{ }^{2}$ admitting free of duty timber from British North. American possessions suitable for the British Navy, and the Act of $1810,{ }^{3}$ which doubled the duties on timber, but exempted from this additional impost lumber imported direct from British North America. ${ }^{4}$

Canada unwillingly let go the old statuteregulated commercial connection with Great Britain. Over the severance of this tie there was much irritation; and also complaints that in adopting free trade-particularly in freely opening the markets of Great Britain to the United States - the British Government had shown a lack of watchfulness for other Canadian interests besides those directly affected by the withdrawal of the preferences which the provinces had enjoyed since 1806 . It was long a complaint in the Maritime Provinces that the British Government, when it was opening the ports of the United Kingdom to the United States, had failed to secure for Canadian shipping any advantages in the carrying trade. For equally long it was a grievance with Canadians that Peel in 1846 did not secure from the United States the free admission of Canadian pro-

1 Cf. Willison, Life of Sir Wilfrid Laurier, ii. 59, 60.

246 G. III. c. 117.

350 G. III. c. 77.

4 Cf. Thoughts on the Impolicy of Altering the Present Rate of Duty on Foreign Timber and Deals, London, 1817, pp. 3-5. 
ducts, ${ }^{1}$ and as long after the fiscal reforms of 1846 as 1863, Canadian protectionists of the Buchanan school were condemning Peel for the severance of the commercial ties which attended the adoption of free trade in England.

Buchanan, in 1863, was even more bitter than when he wrote his letters of 1846 to the Times. "England herself," he declared at a National Policy meeting in Toronto, "has succumbed to a faction whose cry was, perish the colonies rather than our theory. The adoption by England for herself of this transcendental principle has all but lost the colonies, and her madly attempting to make it the principle of the British Empire would entirely alienate the colonies. Though pretending to unusual intelligence, the Manchester school, like our Clear Grits, ${ }^{2}$ are as a class as void of knowledge of the world as of patriotic principle. They do not know that free trade is the contrary principle to that of Empire. They do not know that if you take every dirty child off the street and treat him like your own child, your own child will very soon come to see that he is treated only like the dirty child, and very soon be unable to feel differently from the dirty child. Your own child will soon experience that it is a levelling down, not a levelling up." "As left by the free trade measures of England," he finally

1 Cf. Globe, September 30, 1852.

2 The advanced group of the Liberal party. 
declared, "it was the interest of Canada to be annexed to the United States." 1

Buchanan was neither a manufacturer nor a farmer. He was a newspaper editor and a member of the Legislature. But by 1863 the Association for the Promotion of Industry in Canada, of which he was the most active and prominent member, had secured a significant protectionist victory in the tariff of 1858 ; and Buchanan's speech at Toronto is of value as showing the soreness which was left in Canada by the severance of the commercial tie to Great Britain, which had existed almost unthreatened until 1846.

1 Buchanan's Speech at Toronto, December 1863. 


\section{CHAPTER III}

THE MOVEMENTS FOR FREE TRADE AND ANNEXATION

ALL protection is morally as well as economically bad. It is of the tendencies of a system that I speak, which operate variously, upon most men unconsciously, upon some men not at all ; and surely that system cannot be good which makes an individual or a set of individuals live on the resources of the community and causes him relatively to diminish that store, which duty to his fellow-citizens and to their equal rights should teach him by his contributions to augment.-GLADSTONE.

Four distinct and easily traceable movements in Canada followed from the fiscal revolution of 1846. A free trade league was organised in Montreal as soon as the news was received that free trade was to be adopted in England. ${ }^{1}$ The movement for a reciprocity treaty with the United States-a movement in which the Maritime Provinces as well as Quebec and Ontario had their part-was begun even before Peel's measures were through committee stage in the House of Commons. ${ }^{2}$ The movement

1 Cf. Globe, April 7, 1846.

2 Cf. Globe, March 31 and May 12, 1846; and Report of Reciprocity Meeting, St. John, New Brunswick, May 31, 1848, in Colonial Correspondence, 1848. 
for a National Policy - the movement which has so greatly affected Canadian politics for the last thirty years - had its beginnings simultaneously with the movement for reciprocity $;^{1}$ and finally out of the fiscal changes in England came the agitation for annexation to the United States. This was the short-lived movement that culminated in the manifestoes published at Montreal, Quebec, and Toronto in October $1849 ;^{2}$ the manifestoes attributing all the depression existing at that time to the "reversal of the ancient policy of Great Britain, whereby she withdrew from her colonies their wonted protection in her markets." In these manifestoes it was also declared that by the changes which had been made in England, Canada had been crippled and checked in the full career of private and public enterprise, and stood before the world in " humiliating contrast with its immediate neighbour, exhibiting every symptom of a nation fast sinking to decay." "

Taking these movements according to their effect on political thought and action in Canada, first place must be given to the movement for a National Policy. Next comes the movement for reciprocity; and after these the movements for free trade and for annexation to the United States.

1 Report of Legislature, Globe, May 12, 1846 ; Judge Sullivan's Lecture at Hamilton, November 17, 1847 .

2 Cf. Willison's Life of Laurier, ii. p. 181.

3 There were 325 signatures to the manifesto that was published at Montreal. - Willison, Life of Laurier, ii. p. 181. 
The National Policy movement, which really had beginnings in $1845,{ }^{1}$ will require most attention in this History of Protection in Canada, because within seven or eight years of its inception it had succeeded in impressing itself on fiscal legislation. ${ }^{2}$ By 1858 tariff ehanges were being made at the instigation of the Association for the Promotion of Canadian Industry ${ }^{3}$ - the forerunner of the National Policy League of the seventies and the eighties, and of the Canadian Manufacturers' Association of to-day. By 1859 the protectionist movement had so far affected fiscal legislation as to provoke strong remonstrances from chambers of commerce in Glasgow and Sheffield, ${ }^{4}$ and to endanger the reciprocity treaty with the United States; ${ }^{5}$ and by 1859 Canada was well started on that line of tariff policy of which there were frequent complaints to Downing Street by British manufacturers and in Parliament until as late as $1887 .{ }^{6}$ In short, it is this movement, begun in 1845, and stimulated by events in England in 1846, that has given to Canada the outstanding place she occupies in 1907 among countries which have adopted high tariffs for the protection of industry.

1 Cf. Debate on Budget, Mirror of Parliament, March 3, 1845.

2 Cf. Hincks, Tariff, 1853 ; Globe, September 25, 1852; April $14,1853$.

3 Cf. Buchanan, Britain the Country versus Britain the Empire, 1p. 128-130.

4 Cf. Colonial Corlespondence, 1859.

5 Cf. Congressional Globe (Washington), February 5, 1862.

6 Cf. Hansard, series iii. vol. ccexviii. p. 913. 
Beginning, however, with the movement of least importance-that for annexationthis movement came to a head at Montreal, in 1849 ; and was at most only an episode in the readjustments of 1846 . There were British statesmen between the rebellion of 1837 and Confederation who were not unwilling that Canada should, if she so desired, end the political connection with Great Britain. ${ }^{1}$ But in Canada there has never been any general desire for annexation to the United States; and so long as there are in Canada ten cabinets and ten premiers, with the prestige and patronage of premiers, it is not likely that any movement for annexation can have a more practical outcome than that of 1849 . The political, social, and economic forces that centre about Ottawa and about the capitals of the various provinces, constitute so many barriers against any movement in the direction of annexation; and as population and material wealth increases these barriers will become insurmountable.

There are, in fact, three great barriers against any such movement. The forces I have described constitute the first line of defence against movements like that which came to so little in 1849 . The second line is popular national feeling and aspirations towards nationality; and the third barrier is

${ }^{1}$ Cf. Melbourne to Durham, July 22, 1837; Reid, "Life and Letters of the First Earl of Durhan," ii. pp. 137, 138 ; Peel to Aberdeen, October 25, 184 ; Parker, "Sir Robert Peel," ii. 1p. 388-390. 
the peculiar privileges which the Catholic Church in Quebec and the French-speaking population of that province have enjoyed for a century and a half under British ruleprivileges which must come to an end if ever the provinces of Canada become states in the Federal Union. It is true that annexation was talked about in Canada later than 1849. It was an expedient that was sometimes mooted even after Confederation. ${ }^{2}$ But in these days of widespread prosperity, self-confidence, and hopefulness in Canada, all such talk is of the past. To-day there is absolutely no question affecting the relations of the Dominion to the United States to which less thought is given either north or south of the boundary line. Since Blaine died, and Charles A. Dana ceased to edit the New York Sun, annexation is seldom mentioned on the platform or in the press of the United States. It is even less in the public mind in Canada. It is a question that receded completely into the background in the United States ten or fifteen years ago. In Canada it has been an absolutely dead question for a much longer period; and nowadays it is brought into daylight by Canadian editors and publicists only to refute uninformed references to it that occasionally find their way into Imperialist journals in London.

Since the soreness arising out of the civil

1 Larned's Report on State of Trade with Canada, Executive Documents (Washington), 1870-71. 
war disappeared in the United States, since the Republican party tacitly agreed that it was time to cease waving the "bloody shirt" in presidential election campaigns, the United States and Canada have come to a better mutual understanding of each other's conditions than they had twenty or even fifteen years ago. The feeling of good neighbourliness has also increased, notwithstanding that the Dingley Act and the alien immigration laws are still on the United States statute books, and are a constant source of irritation to Canada. ${ }^{1}$ But Canadians now understand almost as well as Americans that these irritating statutes are the work of politicians at Washington, urged on by protectionists and extreme trade union leaders, and not of the people of the United States. With this constantly improving knowledge on both sides of conditions in the two countries, the feeling has grown up in the United States that not a finger should be lifted to hinder Canada's development under the political system which she regards as best suited to the temperament of her people and to her conditions; while Canada, in these growing years of the new century - the century which she claims as essentially her own ${ }^{2}$ - there has come a new attitude towards both Great Britain and the United States, in fact towards the world at

${ }^{1}$ Cf. Porritt, "Is the United States a Good Neighbour to Canada," New England Magazine, August 1899, pp. 731-736.

2 "The Twentieth Century belongs to Canada."-Sir Wilfrid Laurier, Massey Hall, Toronto, May 20, 1902. 
large, ${ }^{1}$ that has pushed all idea of annexation completely into the background. The idea is now so entirely in the background that the question has ceased to have even an academic interest. There may be an interest in the question as to how long Canada will care to maintain her political tie with Great Britain; but among those who give any thought to this question-whether in the United States or in Canada-there is a growing feeling that when the tie shall be severed the severance will not be due to any desire of the Canadian people to be of the American Republic, but rather to a desire to create a nationality of their own, to repeat the great experiment which the United States have thus far since the Revolution of 1776 made so successfully.

John Young, an Ayrshire man, who came out to Canada in 1825, who was a merchant at Quebec and Montreal for twenty years, and who has a place in the annals of Canadian politics as Commissioner of Public Works in the Hincks-Morin Ministry of 1848$52,{ }^{2}$ was the organiser of the Free Trade Association which came into existence in March 1846. It was Young who wrote the manifesto of the Association which was published at the time that the Legislature and the Boards of Trade of Montreal, Quebec, and Toronto were urging on Downing Street a continuance of

${ }^{1}$ Cf. Whates, Canada : the New Nation, pp. 234-242.

2 Cf. Dict. of Nat. Biog., lxiii. p. 382. 
the old preferences. ${ }^{1}$ Young's argument was that the prosperity of Canada could only be maintained by its trade being rendered free; and by industry and capital being allowed to seek their natural distribution and employment.

"But," continued Young, " apprehensive at the same time that our Legislature is not prepared to give effect by law to these liberal views, we have deemed it prudent and expedient to form ourselves into an association for the purpose of collecting into one body all who agree in opinion with us. United on the basis of free trade, we shall respectfully but firmly demand, in the first place, the removal of all Imperial Acts imposing discriminating or regulating duties; in the second place, the repeal of all duties, Imperial and local, levied on American wheat, provisions, or corn of any kind whatsoever; and lastly, we pledge ourselves to resist, by every lawful means, the future enactment of any protective, prohibitive, or merely regulating duties whatever, believing such to be detrimental to the general interests of society, and at variance with sound policy. We further avow that we entertain the opinion that duties should be levied solely for the purpose of creating revenue to provide for the necessities of the Government and the extension of internal improvements; and that for these objects such articles only should be selected for duty as

${ }^{1}$ Cf. Globe, April 17, 1846. 


\section{PROTECTION IN CANADA сн.}

will afford it without restricting or fettering the general commerce, the carrying trade, or the agriculture of the country."

How long this free trade association survived, I have not traced. Before Confederation, when there were not the present facilities for communication, it must have been more difficult to keep such an association active and vigorous than it is to-day to organise, outside the ranks of farmers and grain-growers, a popular movement against the aggression of the Canadian Manufacturers' Association, and against the spirit of ready acquiescence in which the claims of this protectionist association are met by Governments at Ottawa, whether Liberal or Conservative. Among the newspapers of 1846 the Globe gave the new propaganda its whole-hearted support, and steadfastly adhered to the principles of this Montreal manifesto until the Liberals came into power in 1896 . The free trade movement had also the support of the Pilot of Montreal, of which Francis Hincks was editor from 1844 to 1848 , when he became Inspector-General in the Baldwin Administration of 1848-51. ${ }^{2}$

Young must have had other support in his propaganda, for after 1846 he was of the Legislature. He held office in the HincksMorin Administration of 1851-54, and retired in September 1852, because of his opposition

1 Cf. Globe, April 7, 1846.

2 Cf. Dict. Nat. Biog., xxvi. p. 439 ; Buchanan's Speech at Toronto, 1863, Globe, September 25, 1852. 
to the protectionist tendencies of Hincks, which by this time were well developed, and proclaimed in the Legislature. ${ }^{1}$ Every success of the protectionist movement, begun in 1845 , can be traced on the statute books from 1852 to 1907 . There are no such landmarks of the achievement of the free trade movement. There can be none; for except for the repeal of the duty on coal for a brief period in the early years of the National Policy Governments of Macdonald, and except for the preference for Great Britain enacted in 1897, there was no turning back between 1852 and 1907 in the protectionist measures adopted by the Legislature of Ontario and Quebec, or after 1867 by the Parliament of the Dominion. But this much the manifesto which Young published in 1846 did do. From that time until 1896, as can be learned from the debates in the House of Commons, from speeches in the constituencies, from the editorial utterances of such Liberal newspapers as the Globe and the Witness, and above all from the official verbatim report of the National Liberal Convention at Ottawa, in June 1893, it determined the attitude of the Liberal party towards protection.

Sir W. Laurier and Sir R. Cartwright never made a speech in or out of Parliament against the National Policy without reiterating and emphasising the principle laid down in the manifesto of 1846, that "duties should be

1 Cf. Legislative Reports, Globe, September 25 and 30, 1852. 
levied only for the purpose of creating revenue to provide for the necessities of the Government." There was never a party for absolute free trade in Canada. The Dominion, like the United States, must raise the larger part of its revenue through customs duties. ${ }^{1}$ But from 1846, when Canada obtained her fiscal freedom, until the Laurier Government came into power in 1896-just half a century-it was the constant and unchanging contention of the Liberal party that the revenues of the Government should be raised in accordance with the principles first enunciated in Canada in the manifesto of the Free Trade Association of March 1846. 'These principles for half a century constituted the economic creed of Canadian Liberalism; and there is no better way of showing how continuously and potently they influenced economic thought and Liberalism in Canada until the betrayal of 1897 than by quoting in parallel columns the concluding paragraph of Young's manifesto, and the resolutions on the tariff that were adopted at the National Liberal Convention at Ottawa in 1893.

Montreal Manifesto, 1846.

We further avow that we entertain the opinion that duties should be levied solely for the purpose of creating revenue to provide
Platform of Liberal PARTy, 1893.

We, the Liberal Party of Canada, in convention assembled, declare-That the customs tariff of the Dominion should be based,

1 Cf. Laurier at Imperial Conference, London, May 7, 1907. 
for the necessities of the Government and the extension of internal improvements; and that for these objects such articles only should be selected for duty as will afford it without restricting or fettering the general commerce, the carrying trade, or the agricultural industry of this country.-Globe, April 7, 1846. not as it is now upon the protective principle, but upon the requirements of the public service; that the tariff should be redinced to the needs of honest, economical, and efficient government; and that it should be so adjusted as to make free, or to bear as lightly as possible upon, the necessaries of life; and should be so arranged as to promote freer trade with the whole world, more particularly with Great Britain and the United States. - Official Report, National Liberal Convention, 1893 , p. 71.

Baldwin, who was the leader of the Liberals before Confederation, had advocated these principles even before the Free Trade Association of Montreal published its manifesto. $\mathrm{He}$ gave expression to them in the debate on the address - the address in which Cathcart informed the Legislature of the changes that were making in England in 1846. ${ }^{1}$ Mackenzie, who was Premier of a Liberal Government from 1874 to 1878 , and leader of the Liberal Opposition at Ottawa until 1880, also upheld these principles. So did Mr. Blake and Sir W. Laurier, who succeeded Mackenzie as Liberal leaders; and these principles had fore-

1 Cf. Legislative Reports, Globe, March 31, 1846. 


\section{PROTECTION IN CANADA сн. пI}

most place in the creed of Liberalism until the tariff revisions of 1897 and 1907, when the Liberal leaders went over as absolutely to protection as did Hincks in 1852, when Young retired from his administration, or as Macdonald did on the eve of the general election of 1878 . 


\section{CHAPTER IV}

RECIPROCITY : THE MOVEMENT FOR THE ELGIN-MARCY TREATY. 1846-1854

Since the Maritime Provinces were peopled there never was a decade when prosperity was so marked among all classes, when land rose in value so quickly, when the wharves were so lined with shipping, when the workmen had such steady employment, when the farmers had as good a market, as between 1854 and 1866 , when we had reciprocal trade with the United States of America. - Sir Louis Davies.

THE movement for reciprocity with the United States, which began as soon as it was realised that with the end of the old commercial tie there was to open an era of fiscal freedom for Canada, produced more tangible results than the movement for free trade. It resulted in the Elgin-Marcy Treaty, which was operative from 1854 to 1866 ; and from 1866 to 1899 there was never a time when there was not in Canada a movement for a new reciprocity treaty, or when the Government at Ottawa was not prepared to negotiate through the British Foreign Office with the Government at Washington for a renewal of the treaty 
which was so beneficial to both countries from 1854 to 1866.

Tariffs were a cause of friction between the Canadian provinces and the United States from as early as 1806 . Canadian merchants then complained to the British Government that they were made to pay higher duties on goods carried across the border than were paid by citizens of the United States on goods imported from other foreign countries that were entered at the Atlantic ports; and also that when they carried their goods into the United States by the waterways, they were compelled to discharge their boatmen and hire American boatmen as soon as they arrived in the territory of the United States. ${ }^{1}$ Trade conditions between the two countries were on a better basis after the Treaty of 1815 ; for this treaty provided that the inhabitants of Canada and the United States should have liberty freely and securely to come with their ships and cargoes to all places, ports, and rivers in their respective territories, and to hire and occupy warehouses, and enjoy the most complete protection and security for the purpose of their commerce. ${ }^{2}$

The treaty of 1815 affected only the conditions under which Canadian merchants and traders did business in the United States. It secured for them no advantage under United

1 Cf. Hodgins, British and American Diplomacy affecting Canada, 1782-1899, p. 70.

${ }^{2}$ Cf. Hodgins, p. 75. 
States tariffs; and from 1832 the duties on farm produce such as Canadian farmers had for export were increased so much that by 1846 they ranged from twenty to thirty per cent, and constituted a serious barrier against trade with the United States. These duties were imposed by an Act of Congress which went into operation in the year ${ }^{2}$ when the old preferences on Canadian products at British ports began to come to an end; so that in 1846 two forces-one British and the other American-were impelling Canadians to move for reciprocity with the United States.

As soon as it was known in Montreal and Toronto that fiscal freedom for Canada must result from the changes of 1846, the idea took root that the British Government must permit the Provinces to enter into reciprocal trade with the United States; and, as I have already shown, some soreness was engendered by the fact that the British Government did not insist on reciprocity for Canada when it was throwing open the ports of Great Britain to imports from the United States.

Before expression could be given in the Legislature to this popular desire for reciprocity, the question was discussed in the Globe, then edited by George Brown, and already the most influential newspaper in the provinces of Ontario and Quebec." "If trade

1 Cf. Comparative Tables of Present and Past Tariff, Washington, 1884 , pp. $132,133$.

2 July $30,1846$. 
is to be free," urged the Globe, on March 31, 1846 , "it must be equally free between British colonies and foreign countries. A free intercourse with the United States, and the use of her ports for the export of Canadian produce to European markets should form an indispensable part of the new arrangements, and also the supply of manufactured goods from the cheapest market. If these, with cheap postage and other arrangements, are completed, the friends of Canada have nothing to fear on her account."

In the Legislature at Quebec, the question came up for the first time after it was known that the old preferences were to come to an end, on May 4, when Merritt proposed an address to Her Majesty, asking, among other requests, that the British Government would open negotiations with the Government at Washington to secure free access for the products of Canada into the United States on the same terms as American products were to be admitted into the markets of Great Britain and Canada ; ${ }^{1}$ and from May 1846 , until the treaty was in sight in 1854 , reciprocity was the foremost question in Canadian politics.

By 1848 New Brunswick was as eager for reciprocity as Ontario and Quebec. Meetings in support of it were held at St. John and Fredericton in May and June of that year, at which resolutions were adopted, copies of which were ordered by the St. John meeting

${ }^{1}$ Cf. Globe, May 12, 1846. 
to be "communicated to influential members of the United States Congress, urging the inclusion of New Brunswick in the Act now before that body to regulate the interchange of certain articles between Canada and the United States." 1 The repeal of the navigation laws, which had been of much advantage to St. John, gave an added impetus to the reciprocity movement in New Brunswick-the province which is divided from Maine only by the St. Croix river. As soon as news was received that changes were being made in the navigation laws at Westminster, there was another public meeting at St. John. It was then complained that Great Britain had been neglectful of colonial interests when she abandoned protection without securing reciprocity for Canada; and it was also declared that the pending repeal of the navigation laws would be a calamity for New Brunswick, unless it were attended with the opening of other markets for New Brunswick produce. ${ }^{2}$

As early as May 1848, Elgin, who in 1847 had succeeded Cathcart as Governor-General, was urging on the British Government the importance to Canada of reciprocity with the United States. "The advantages to the colonists in the British market afforded them

1 Sir Edward Head, who was Governor of the province, in forwarding the reports of the meetings to Grey, who at this time was Secretary for the Colonies, informed him that "the trade of this province is at the present moment in a most depressed state." -Colonial Correspondence, 1848.

${ }^{2}$ Colonial Correspondence, 1848. 
by means of protecting duties generally enabled them," he wrote, " to overlook the disadrantage of having the markets of the United States closed to them by duties levied in that country in favour of native productions"; ${ }^{1}$ and in March 1849 , Elgin again returned to the subject in a letter to Grey, Secretary for the Colonies. "There has been," he wrote, with reference to the agitation that resulted in the annexation manifestoes at Montreal and Toronto, "a vast deal of talk about annexation, as is unfortunately always the case when there is anything to agitate the public mind. A great deal of this talk is, however, bravado, and a great deal the mere product of thoughtlessness. Undoubtedly it is in some quarters the utterance of very serious conviction ; and if England will not make the sacrifices which are absolutely necessary to put the colonists here in as good a position commercially as the citizens of the States-in order to which free navigation and reciprocal trade with the States are indispensable; if not only the organs of the league ${ }^{2}$ but those of the Government and of the Peel party are always writing as if it were an admitted fact that colonies, and more especially Canada, are a burden to be endured only because they cannot be got rid of, the end may be nearer than we wot of." 3 Elgin wrote again in November 1849, of the political unrest

1 Cf. Elgin Despatches, May 12, 1848, Hansard, series iii. vol. cvi. p. 602 .

2 The Corn Law League.

3 Walrond, Letters and Journals of Lord Elgin, pp. 100-102. 
in Canada. "I much fear," he then informed the Colonial Office, "that no measure but the establishment of reciprocal trade between Canada and the United States, or the imposition of a duty on the produce of the States when imported into England, will remove it." 1

As far back as June 1846, the British Government had returned a favourable answer to the address to the Crown from the Legislature of the United Provinces ; and in accordance with this answer, Pakenham, the British Minister at Washington, in December 1846, broached the subject of reciprocity to Walker, Secretary of the United States Treasury-the department which had charge of Federal matters affecting trade and commerce. The United States Government was well disposed towards the movement, and it was agreed to proceed by means of concurrent legislation by the United States and Canada. ${ }^{2}$ In June 1849, Herries, President of the British Board of 'Trade, informed the House of Commons that the Government would be glad to cooperate in bringing about the arrangement with the United States that was then so much desired by all the provinces of Canada. "The price of wheat and flour in the eastern states, intended for home consumption," said Herries, in explaining to the House the object for which Elgin was working, "is often much higher

1 Walrond, Letters and Journals of Lord Elgin, pp. 100-102.

2 Cf. Haynes, The Reciprocity Treaty with Canada of $1854,11$. 
than the price in Canada for exportation. When this happens to be the case, it would be an immense advantage to the Canadian agriculturalist could he export his produce for consumption in the United States. This, however, he is prevented from doing by a protecting duty of a quarter of a dollar a bushel upon wheat." Herries further informed the House of Commons that a reciprocity bill had been introduced in Congress at Washington, but had not been proceeded with on account of the lateness of the session. "The American Government," he added, "would be advised in every way of the disposition of the British Government to facilitate the important object of establishing a free intercourse for articles of produce across the border." 1

In the middle years of the nineteenth century reciprocity was of vital importance to all the British North American colonies. It gave a value to the farm lands of Ontario and Quebec equal to that of farm lands in New York, Ohio, Indiana, Iowa, Illinois, and Wisconsin. For New Brunswick, Nova Scotia, and Prince Edward Island it opened a large, adjacent, and natural market for lumber and fish ; and it found employment for shipping ; all of which was of enormous value to the Maritime Provinces. For the United States reciprocity was then at most only of sectional value. It had great advantages for the manufacturing industries of New England, chiefly

${ }^{2}$ Hansard, iii. vol. cvi. pp. 602-604. 
as regards their supplies of coal and of raw material. It also conferred benefits on the New England fishing industry; while the opening of the St. Lawrence and its canals to American shipping was of much value to the state of New York and to the grain-growing states of what is now the Middle West.

It consequently followed that when reciprocity first began to be discussed in 1846 there was much more eagerness for it in British North America than there was in the United States, and that much work in the education of public opinion had to be done by Americans favourable to reciprocity before success finally attended the movement. But from the outset, notwithstanding that protection in the United States had by 1846 strongly impressed itself on legislation at Washington, Canada had good grounds for hoping that the United States would not be unwilling to come into closer trade relations; for Jefferson, Clay, and Van Buren had long ago urged a liberal trade policy towards the British North American Provinces. ${ }^{1}$

The first overtures were from the United Provinces-Ontario and Quebec-and it was not until 1848, when the first of the series of reciprocity bills was before Congress, that New Brunswick and the other Maritime Provinces came fully into the reciprocity movement. It was the original intention of the United Pro-

${ }^{3}$ Executive Documents, House of Representatives, No. 96, 36th Congress, First Session. 
vinces to make their own terms with Washington, and to leave the sister provinces of New Brunswick, Nova Scotia, and Prince Edward Island to look to themselves if they also desired reciprocity with their neighbours of the Republic. In May 1846, as has already been stated, there was an appeal from the United Provinces to the British Government to use its good offices in securing reciprocity for them ; and in the first session of the Legislature the Government of the Canadas itself gave notice to Washington that they were anxious to establish improved trade relations, to be based not on a treaty but on concurrent legislation enacted by the Canadian Parliament and by Congress.

A treaty did not really become necessary until a much later stage-until the Maritime Provinces were eager to come into the movement, and were willing to make concessions to the fishermen of New England which would involve an easier intexpretation of the conditions of the treaty of 1818. The first direct intimation to Washington of the eagerness of the United Provinces for reciprocity took a practical form. There was embodied in the first Tariff Acts passed by the Legislature since its new powers had been conferred on it by the British Act of 1846, not only clauses which admitted American manufactures on the same terms as manufactures from Great Britain, but also a clause setting forth that if the Government at Washington would admit free of 
customs duties certain of the natural products of Canada, the Legislature of Canada would grant free admission to similar products from the United States. ${ }^{1}$

Two years elapsed before any sign of interest in the new movement was shown at Washington. But in July 1848, the Committee on Commerce of the House of Representatives presented a reciprocity bill to the House much on the lines of the resolution that had been before the Canadian Legislature in 1846. The bill was promptly accepted by the Lower House, ${ }^{2}$ and on the same day it went to the Senate, where immediate consideration was asked for it by Dix, Senator from the State of New York. ${ }^{3}$ It was obviously a measure in which the State of New York was much concerned, for in the House one of its strongest advocates was McClelland of New York; and in this session and in the session of 1849 reciprocity and Canada generally had no warmer friend at Washington than the Senator from New York, who is known in United States political and military history as General Dix. In later years Hale, of New Hampshire, was an excellent friend of Canada, and he amply demonstrated his friendship when the reciprocity treaty was successfully assailed in the Senate in 1865. But in the Senate or the House no man stands out more prominently in the annals of

1 Cf. Statutes of Canada, 11 Vict. c. 1 ; 12 Vict. c. 3.

2 Congressional Globe, July 20, $1848 .{ }^{3}$ Ibid. 
Washington as a friend to Canada than the Senator from New York, who, on July 20, 1848, pleaded with his colleagues of the branch of Congress proverbial for dilatory Parliamentary procedure, to give immediate consideration to the reciprocity bill that had come up from the House of Representatives. Dix's plea was unavailing, and the reciprocity bill went over until the next session of Congress. $^{1}$

On December 18, 1848, within a few days after the beginning of the new session, Dix gave notice that on the 19th he would call up the bill; and on the 19th he again made his plea of urgency - this time on the ground that the session of the Canadian Parliament was about to open, and that it was essential that it should be known what action Congress was likely to take. An adverse vote-seventeen ayes to twenty-six noes-was the response of the Senate to the plea of the Senator from New York that this bill should be made a special order and be immediately proceeded with $;^{2}$ and it was January 8, 1849, before Dix addressed the Senate on the merits of the bill, and urged that the United States should respond to the overtures of Canada to get rid of the embarrassments that attended commerce between the two countries. ${ }^{3}$

Great Britain, in the meantime, had made

1 Cf. Congressional Globe, July 20 and December 18, 1848.

2 Ibid. December 19, 1848

${ }^{3}$ Ibid. Jantary 8, 1849. 
it known at Washington that she was desirous for reciprocal trade between the United States and Canada. ${ }^{1}$ Elgin, the Governor-General, was exerting himself to the same end; and at the time that the bill of 1849 was before Congress Elgin had commissioned Merritt, who had moved the reciprocity resolution in the Canadian Parliament in 1846 , to visit Washington in the interest of the bill. ${ }^{2}$ While in Washington, according to American authorities, Merritt is stated to have promised that an extension of the principle of reciprocity to manufactures of the United States and Canada could be obtained at any future time if deemed desirable by the United States. ${ }^{3}$

In speaking to the bill on January 8, Dix urged immediate action, again on the ground that the Parliament of Canada was anxious to know the fate of the measure. One of the most important objections raised against the bill came from Pearce of Maryland, who insisted that Canada was a foreign country, and that free trade in natural products between the United States and Canada, based on reciprocal legislation, must result in free trade in bread stuffs, and might endanger reciprocity treaties then in existence between the United States and Russia, Austria, Portugal, Sardinia, several of the German Principalities, and some of the countries of South America. Pearce

1 Cf. Hansard, series iii. vol. cvi. pp. 602-604.

2 Haynes, Reciprocity Treaty with Canada of 1854, p. 12.

3 Cf. Larned Report, Executive Documents, 1870-71, p. 35. 
regarded the bill as an inroad on the protection enjoyed by grain growers in the United States under the tariff of 1846-a protection of twenty per cent ad valorem-and objected to the inroad because all the advantages of reciprocity would accrue to the railway companies and millers of New York, and to the shippers and manufacturers of New England.

Other objections were that the bill must be partial and unequal in its operation; that it was a quasi-annexation bill; that the United States could market no natural products in Canada because the products of the two countries were so similar; that it did not offer any advantages to the manufacturers of the United States; that it would confuse the revenue system of the Government; and that it was to some extent a sectional as distinct from a national measure, because only the northern states could derive any advantage from it. Douglas of Illinois supported the bill because of its advantages to American coastwise and lake shipping, and to American railways and canals ; and Westcott of Florida, because he looked upon it as a measure in the direction of free trade. "It is because I am uncompromising in my support of that principle," he said, "that I shall vote ifor this bill -because it maintains the doctrine of free trade." 1

The greatest effort in support of the bill was made by Dix, on January 29. He recalled

${ }^{1}$ Cf. Congressional Globe, January 8, 1849. 
the Act of the Canadian Parliament of 1846 , and the advantages it afforded the United States in its provisions for the admission of manufactures from the United States at the same customs rates as manufactures from Great Britain. "For two years," he proceeded, "we have had this advantage, and now the people of Canada are asking for equality in the exchange of a few agricultural products common to both countries. I should deeply regret that the United States, powerful and prosperous as they are, should withhold from a comparatively weak and dependent neighbour a privilege claimed on grounds so fair in themselves, and so entirely in accordance with the liberal principles by which we profess to be governed. It would be a poor encouragement to a country adopting our political maxims to some extent, and carrying them into the administration of her own commercial affairs, to be driven from the liberal system she has espoused into the old system of exclusion; to be thus checked in the very outset in her attempt to cast off the shackles which she has regarded as the greatest impediment to her prosperity; to be driven to this alternative too by us - the country above all others most interested in the establishment and maintenance of an enlightened policy in government and commerce."

Dix's stirring appeal was unavailing. No

1 Congressional Globs, January 23, 1849; and Speeches and Occasional Addresses, by John D. Dix, pp. 383-412. 
progress was made with the measure in 1849 ; and it was May 1850 before it was again discussed in Congress. In the meantime the two Governments had been in correspondence ; and in June 1849 the British Government had been informed that the United States Government did not regard the offer of Canada of free admission of natural products of the United States as an equivalent for the free admission of these products of Canada into the United States. The British Government was asked what other concessions would be made, and in particular whether the navigation of the St. Lawrence would be opened to American shipping. It was March 1850 before the Washington Government was officially informed that the British and Canadian Governments were ready to make this concession; and on the basis of this information the Committee on Commerce extended the reciprocity bill, and a new appeal was made to the grain-growing states of the Middle West.'

The bills of 1848 and 1849 had provided only for the free admission into the United States of "grain and bread stuffs of all kinds; fruit, animals, hides, wool, tallow, horns, salted and fresh meats; ores of all kinds of metals ; timber, staves, wood, and lumber of all kinds." In May 1850 the House Committee on Foreign Affairs presented a report asserting the natural right of great inland communities situated upon the sources of a

${ }^{1}$ Cf. Congressional Globe, January 11, 1865. 
navigable river to pursue its channel to the ocean without material obstruction from any community organised over the mouth or the lower section of the stream, and asking that the application of this principle to the St. Lawrence might be the subject of concurrent legislation, or of a treaty between the United States and Great Britain, thus transforming a natural right to an international obligation. ${ }^{3}$

A few days later-May 15, 1850-President Taylor transmitted to Congress the correspondence in which Great Britain expressed her readiness to concede the navigation of the St. Lawrence; and in the accompanying message the President asked Congress to determine whether it regarded the two concessions - free admission of the natural products of the United States into Canada and the opening of the canals and the St. Lawrence-as an equivalent for the market which would be conceded to Canada by the United States. ${ }^{2}$

The fugitive slave law and other questions arising out of the extension of slavery into the new territories were at this time engaging attention at Washington. There was no strong popular impulse behind the reciprocity measure; and consequently no definite action was taken by Congress in 1850 ; and in the history of the reciprocity treaty which was agreed upon in 1854 , the year 1850 is chiefly

1 Congressional Globe, Jamuary 11, 1865.

${ }^{2}$ Richardson, Messages and Papers of the Presidents, v. 44, 45. 
memorable for the advance that the movement made in the United States - for the wider form it assumed-after it was known that Canada was willing to open the Welland and St. Lawrence canals and the St. Lawrence river to American shipping.

President Taylor died in July 1850. Fillmore, who had been Vice-President, was his successor ; and in his message of December 2,1850 , he recommended reciprocity legislation to Congress. The outlook for reciprocity had never been more hopeful than it was in the winter of 1850-51. The movement had assumed a new importance to the United States when it became known in New York and in the other states bordering on the Great Lakes that Canada would open the St. Lawrence and its connecting canals. It had gained much by Fillmore's endorsement; and in January 1851, Hincks, InspectorGeneral in the Canadian Government, was at Washington-as Merritt had been in 1849and was in direct communication with the Committee of the House which was concerned with reciprocity legislation. On January 6, 1851 - three days before the bill came up again in the Senate-Hincks wrote a long letter to the Chairman of the House Committee on Commerce, recounting the history of the movement in Canada, and answering objections which had been made to the reciprocity bills when they were before Congress in 1848 and 1849. 
"The consequence of the withdrawal of the protection formerly enjoyed by the colonies," he wrote in reference to the fiscal reforms in England in 1846, "has been that they have been left to buy and sell in the markets of the world just as the United States or any other foreign nation. In 1846 the Canadian Legislature, having been authorised by an Act of the Imperial Government to regulate their own tariff, and being anxious to cultivate a free commercial intercourse with their powerful and enterprising neighbours, removed the existing duties and admitted American manufactures and foreign goods purchased in the American market on the same terms as those from Great Britain. Had Canada at that time stipulated with the United States that in return for her admission of American manufactures the duties should be remored from her products, it would obviously have been the interest of the United States to agree to such an arrangement. No such proposition, however, was made; and this very important concession to the United States seems scarcely to have attracted the attention of your Federal Government; and so little was it understood that when General Dix urged it as an argument in favour of the reciprocity bill in the Senate, the fact was disputed."

Hincks, in this letter of January 6, next called attention to the increase of Canadian imports from the United States since 1846- 
an increase which had swelled the customs receipts at Toronto from $\$ 30,000$ to nearly $\$ 400,000$-and urged that the consequence of this trade had been that "the Canadians had been led to export their raw products to the same markets from which they had drawn their supplies." "Here," he continued, "they are met by a heavy American duty on their staple commodities-lumber and bread stuffs." $\mathrm{He}$ denied that all the gain of reciprocity would accrue to Canada; and intimated that if no reciprocity bill were enacted at Washington, Canada might be compelled to retaliate. "It is assumed by the opponents of the bill," he wrote, "that in the event of the bill being rejected by the American Congress, Canada will maintain her present commercial policy, and continue to foster the import trade from the United States. But I have no hesitation in stating that the advocates of a retaliation policy are rapidly gaining ground. The reimposition of the differential duties against the United States has been strongly urged. Such a measure would be most acceptable to the commercial interests of Montreal, whose trade was seriously injured by their repeal. At the close of the last session of our Parliament an influential member of the Opposition, a gentleman who held under a former administration the office which I have now the honour to fill, gave notice of his intention to introduce a bill during next session to 
reimpose these duties. Leading organs of the Opposition have strongly advocated such a measure, and no doubt can be entertained that it will engage the attention of Parliament at an early day. Should it be adopted, the United States will have no just cause of complaint. They never invited Canada to repeal the differential duties, and their rejection of the reciprocity bill would, of course, be looked upon as a deliberate rejection of the Canadian trade. In England the reimposition of the differential duties by Canada would be viewed most favourably, and there can be no doubt that the effect would be to stimulate the efforts of those who are seeking to obtain some modification of the present corn laws."

Hincks also hinted that as another measure of retaliation Canada might completely close the canals to American shipping. At this time they were partially closed, and American vessels were admitted to their use only on special application to the Government. Such a course, he urged, would inflict serious harm on the trade of Chicago, Cleveland, and other lake ports; and on New England railway interests and the New York northern canals. It would involve some loss of tolls for Canada; "but," added Hincks, "as that revenue forms an insignificant portion of the resources of the province the loss would form no inconvenience." What action the Government of Canada would take in the 
event of the rejection of the reciprocity bill Hincks was not authorised to state. "Indeed," he added, "its policy has not yet been determined upon." "Since the accession of the present administration to office in 1848," he continued, "they have been watching with anxiety the proceedings of Congress regarding the reciprocity bill; and my object in visiting Washington at this time was to ascertain if possible the probable fate of that measure, as the Government must be prepared at the approaching session to meet Parliament with a definite policy regarding our commercial relations with the United States." 1

Douglas of Illinois, who had taken the place of $\operatorname{Dix}^{2}$ as sponsor for reciprocity measures in the Senate, succeeded, on May 9, 1851, in getting the bill into committee of the whole ${ }^{3}$ but again, as in previous sessions, it made no headway; and in June 1851, Bulwer, who at this time was British Minister at Washington, was in correspondence with Webster, Secretary of State in Fillmore's cabinet. Earlier than this, in March 1851, Bulwer had transmitted to Webster a copy of Hincks' letter of January 6 ; recalled the fact that at the time Hincks addressed the Chairman of the House Committee on Commerce it was hoped that Congress would enact a reciprocity bill; and added that in

1 Cf. Hincks to M'Lane, Chairman of Committee of Commerce, House of Representatives, Executive Documents, 1850-51.

2 Dix's term as Senator expired March 3, 1849.

3 Cf. Congressional Globe, May 9, 1851. 
March, when these expectations had not been realised, Canadians seemed to believe that their only mode of obtaining adequate attention was to place themselves in the situation in which they had stood before 1846-before they repealed the differential duties. ' Writing to Webster again on June 24, Bulwer reiterated his expressions of disappointment at the failure of the bill, and informed the Secretary of State that unless he could hold out some hope that the United States would come into the movement, "the Canadian Government and Legislature is likely forthwith to take certain measures which will effect a considerable change in the commercial intercourse between the Canadas and the United States."

Bulwer's letter was accompanied by a letter from the Governor-General of Canada to Bulwer, dated Toronto, June 7 , in which Elgin told Bulwer that he could not conceal from him his belief that, unless "you are enabled to give me some assurance that negotiations with the Government of the United States are in progress which are likely to result in placing the commercial relations between the provinces and the United States on a more satisfactory basis, it will not be in my power any longer to refrain from adopting the steps which the Inspector-General suggests, and which may, I think, very probably be followed by others

1 Executive Documents, Senate 1851-52. 
calculated to check trade between British North America and the United States."

What steps Hincks was urging on Elgin at this time can be learned from a memorandum that accompanied the Governor-General's letter to Bulwer. This shows that Hincks was recommending the closing of the canals to American shipping; that Robinson, a member of the Legislature, had on the order paper a resolution calling for the imposition of a duty of twenty per cent on imports from the United States and the re-enactment of differential duties to encourage importers to bring their goods into Canada by way of the St. Lawrence instead of through the United States; and that Merritt was proposing a petition to the Queen, praying Her Majesty to recommend the Imperial Parliament to enact that similar duties be imposed on foreign produce of the kinds for which Canada was seeking free entry into the United States as were levied on similar British produce in foreign countries. $^{1}$

These communications from Bulwer, Elgin, and Hincks to Webster of June 24, 1851, were all preliminary to an inquiry as to whether the United States Government was disposed to open negotiations for a treaty; and they mark the third distinct stage in the movement by Canada for reciprocity. The first of these stages was the movement for

1 Cf. Executive Documents, Senate 1851-52, vol. i. pt. i. pp. 87-91. 
reciprocity based on concurrent legislationthe stage at which Canada offered free trade in natural products in return for similar favours from the United States. The second stage was reached in March 1849, when, as a make-weight to offset the contention at Washington that most of the advantage of reciprocity must accrue to Canada, it was proposed to open the canals and the St. Lawrence to American shipping. The third stage was reached in June 1851. By this time the reciprocity movement was no longer confined to the Canadas. The Maritime Provinces were now as eager for reciprocity as Ontario and Quebec; and with the incoming of New Brunswick and Nova Scotia into the movement there was introduced for the first time the question of the difficulties which from time to time had arisen under the fisheries article of the treaty of 1818 .

The fisheries question had been the subject of diplomatic interchanges between Washington and London as recently as 1845 . Some concession was then made to the United States, and in particular to the fishermen of Gloucester and other New England ports, in the interpretation of the treaty of 1818 ; but only in so far as affected the rights of American fishermen in the Bay of Fundy. The whole question, as it concerned the Maritime Provinces and Nerwfoundland, came up again between 1851 and 1854. It was at an acute stage in 1853 . 
It may have been only a coincidence that trouble arising out of the British interpretation of the treaty of 1818 broke out anew when the Canadas and the Maritime Provinces were literally begging for reciprocity. It may have been only a coincidence that the British Government in 1853 deemed it necessary to send cruisers to the waters of British North America to enforce its interpretation of the treaty. But there can, I think, be no doubt that Elgin used the recrudescence of the fisheries trouble as a means of exercising strong and continuous pressure on the Government at Washington to make the trade concessions for which Canada had been agitating since 1846.

Four measures of retaliation were threatened in the communications from Toronto, dated June 7, 1851, which Elgin forwarded to Bulwer for submission to Webster. These were (1) the closing of the canals; (2) the imposition of duties of twenty per cent on imports from the United States; (3) the reenactment of differential duties to draw trade to Quebec and Montreal; and (4) the appeal through the Queen to the British Parliament to re-enact duties on the natural products of the United States imported into Great Britain.

Only two of these measures were within the power of the Legislature of the Provinces. It could close the canals. It could also add to the tariff wall against the United States; but even if Ontario had not objected to the 
differential duties in favour of Montrealduties which would have much embarrassed merchants and importers in Toronto, Hamilton, and London in the winter season, when the St. Lawrence is closed with ice-it is exceedingly probable that the British Government would have disallowed a differential duties bill. It is certain that Great Britain in 1852 or 1853 would not have reversed her commercial policy of 1846 merely to punish the United States for their refusal to take down the tariff wall against the farm products, the lumber, and the fish of the British North American Provinces. Elgin must have known that at most only two of these four threatened retaliatory measures were within the powers of the Canadian Parliament; and clearly he had the treaty of 1818 in mind when he wrote that the measures under discussion at Toronto in 1851 might "very probably be followed by others calculated to check trade between British North America and the United States."

The difficulties under the treaty of 1818 arose out of the British contention as to the measurement of the three-mile limit. As the treaty stood at this time New England fishermen had the right to go into the bays and harbours of British North America only for four purposes-shelter, repairs, for the purchase of wood, and to obtain water, "and for no other purpose whatever." ${ }^{1}$ The position of

1 Article I. treaty of 1818. 


\section{PROTECTION IN CANADA сн.}

the British Government was that the measurement must be taken from the headlands at the entrance to the bays; and under this interpretation American fishermen were excluded from George Bay, the Bay of Miramichi, the Straits of Northumberland, and the Bay of Chaleurs.

At one time the British Government was inclined to exclude them from the Bay of Fundy; but a more liberal construction was adopted with regard to these waters, and exclusion from them came to an end in $1845 .^{1}$ The contention of the United States Government was that American fishermen had the right to enter and fish in any of the bays that indent the shore, provided they did not approach for the purpose of taking fish within three marine miles of the coast by which such bays were encompassed. ${ }^{2}$

From about 1830 New England fishermen had been pursuing the mackerel fishery in the waters of the Maritime Provinces; and as Webster was from Massachusetts, and was alive to the inconveniences that might result to New England fishermen under the British interpretation of the treaty, and as he was also anxious to avoid any friction with Great Britain, he readily gave his support to the reciprocity movement, when he was approached

1 Cf. Lord Aberdeen to Mr. Everett, 1845, quoted in Instruction to Commodore Shubrick, July 14, 1853, Executive Documents, 1854.

${ }^{2}$ Cf. Instructions to Commodore Shubrick, Congressional Globe, January 13, 1865. 
by Bulwer in June 1851. Little, however, was accomplished in Congress in that year. The House Committee on Commerce in 1852 again favourably reported a reciprocity bill ; but perplexing territorial questions were at this time engaging attention, and 1852-the fourth year of the movement-came to an end without Douglas and Amos Tuck, now the foremost advocates of reciprocity in the Senate and the House, being able to report much progress.

The failure of the movement in 1852 to make progress at Washington had an irritating effect in Canada. Hincks went so far in the direction of tariff war as to obtain power from Parliament to impose higher duties on American imports by order in council. ${ }^{1} \quad$ At these seasons of irritation and despair there was a recrudescence of the old feeling that Canadian interests had been neglected by Great Britain. Twice in the Parliamentary session of 1852-53 Hincks bitterly complained that Great Britain, when repealing the corn laws, had not availed herself of that opportunity for obtaining reciprocity for Canada ; ${ }^{2}$ and in the budget debate of 1853 Merritt brought forward the retaliatory proposal adverted to in the correspondence between Elgin and Bulwer in June 1851urged that Great Britain should reverse her free trade policy of 1846 to compel the United States to come to terms with Canada. ${ }^{3}$

1 Legislative Reports, Globe, September 30, 1852.

2 Ibid. September 30 and November 9, 1852.

3 Ibid. April 21, 1853. 
Reciprocity for Canada was a great and absorbing question. For the United States it was not a question of much moment; for in the form in which it was sought by Canada it was not to include a free exchange of manufactures. Canada had no manufactures for export. Manufacturing had scarcely begun there in the early fifties of the nineteenth century; and while free trade in manufactures would have opened no market in the United States for Canadian manufacturers, the free admission of American manufactures would have interfered with the revenue system of the provinces, and would also have set up discriminations against Great Britain. That free trade in manufactures was not offered by Canada accounts in some degree for the lack of popular interest in the United States in the reciprocity movement between 1848 and 1852 . The movement would have been still longer in making headway at Washington had it not been for the introduction of the questions of the canals and the St. Lawrence in 1849, and the fisheries in 1851. The fisheries question gave reciprocity a new importance. It was this phase of the movement that Webster emphasised at Marshfield, Massachusetts, in the autumn of 1852; and it was to this aspect that Amos Tuck directed the attention of the House of Representatives when reciprocity was again discussed in February 1853. "Our people," said Tuck, speaking for the fishermen of New England, 
" cannot go through another summer without involving themselves with the people of the provinces. Mackerel-fishing cannot be pursued without going inshore; and there is a danger of bloodshed." I

President Franklin Pierce also called attention to this aspect of the question in his first annual message to Congress on December 5 , 1853. "Our diplomatic relations with foreign powers," wrote Pierce, "have undergone no essential changes since the adjournment of the last Congress. With some of them questions of a disturbing character are still pending; but there are good reasons to believe that these may be amicably adjusted." $\mathrm{He}$ called attention to Great Britain's construction of the Convention of 1818; assured Congress that the United States had never acquiesced in that construction, but had "always claimed for their fishermen all the rights which they have so long enjoyed without molestation." "With a view to remove all difficulties on the subject, to extend the rights of our fishermen beyond the limits fixed by the Convention of 1818, and to regulate trade between the United States and the British North American Provinces," continued the President, "a negotiation has been opened with a fair prospect of a favourable result. To protect our fishermen in the enjoyment of their rights, and to prevent collision between them and the British fishermen, I deemed it expedient

1 Congressional Globe, February 23, 1853. 
to station a naval force in that quarter during the fishing season." 1

Hincks told the Canadian Parliament in April 1853 that since September 1852, when there appeared little prospect of Canada obtaining reciprocity, the British Government had threatened the United States with stringent regulations regarding the fisheries of the Maritime Provinces. ${ }^{2}$ A British naval force had subsequently taken over the work of fishery patrol; and the United States naval force, to which President Pierce referred, consisted of four vessels, which, from July to September 1853, were in British North American waters, discharging what the Secretary of the Navy described, in his instructions to Commodore Shubrick, as "delicate and responsible duties." In his instructions Shubrick was told that the British forces under Sir George Seymour were fully armed and manned; that in consequence it was felt by the American fishermen that "there is a settled purpose to disturb them in the enjoyment of their fishing privileges." Armed fishing vessels had gone out from the New England ports - so it was understood at Washington-prepared to take the defence of their rights into their own hands; and while the President entertained the opinion that American fishermen had the right to enter the bays and harbours and to take fish

1 Executive Documents, No. 4, 1853.

${ }^{2}$ Cf. Globe, April 14, 1853. 
there provided they did not approach within three marine miles of the shore, Shubrick was instructed to "warn fishermen never to venture where treaty stipulations do not strictly authorise them"; and himself never to resort to violence except in self-defence and of necessity.

There was no serious trouble during the fishing season of 1853. On August 13, the schooner Starlight of Gloucester was seized by a vessel of Seymour's command, and sent to Charlottetown, for flagrant violation of the terms of the treaty. But the schooner was released on August 15, on the master admitting that he had broken the law, and undertaking to act within its provisions in the future. Shubrick ascertained at the New England ports that no vessels had gone out armed or looking for trouble; and from the United States consuls at the Maritime Province ports he found that there had been no complaints of transgression by the New England fishermen; and he sailed for Charlottetown "thoroughly convinced that so far from any obstruction being thrown in the way of American fishermen" during the season of 1853 , "they are rather invited and welcome in the provinces." Watson, who commanded the U.S.S. Fulton, passed between five and six hundred fishermenProvincial and American-in the early days of September, and reported to Shubrick that there appeared to be the greatest harmony 
between the New Englanders and the inhabitants; and that the New Englanders were welcomed on the coast. Seymour, the British admiral, told Shubrick at Halifax, on August 7, that there was to be no deviation from the British interpretation of the treaty of 1818 ; but that his instructions were to "carry out the views of the Government in the mildest manner; and not to make any seizures except in case of undoubted infraction of the treaty." No seizure had then been made; and Seymour anticipated no trouble, except from the imprudence of individuals, arising from an attempt to take the law into their own hands.

Seymour's communication to Shubrick at Halifax was in line with what was understood at Washington to be his instructions. "Admiral Seymour," wrote Secretary Doblin to Shubrick, July 23, "will not resort to violence even if our fishermen do venture to fish in the bays, unless it is indulged in with display of arms, and in a manner and spirit of defiance, calculated to irritate and offend, which I do not allow myself to suppose will occur." 1

Had it been practicable to examine the instructions to Seymour, and the communications that passed between the British Admiral and his commanders, and also to search the files of the St. John, Halifax, and Charlottetown newspapers for 1852

1 Executive Documents, No. 21, 1853. 
and 1853 , it is possible that some traces of irritation among the Provincial fisher-folk might have come to light. But a study of the instructions to Shubrick, and his reports, leaves the impression that the trouble that was expected between the Provincial and the New England fishermen was political and factitious, and that bad there been no treaty pending, there would have been no expectation of trouble either in London or Washington.

Polk, Taylor and Fillmore, and Pierceevery President from 1846, when Canada began to move for reciprocity, until 1853was in favour of some trade arrangement with the British North American Provinces. So were Clay and Webster, who were at the State Department in these years. But an administration at Washington has not the advantage that an administration at St. Stephen's or at Ottawa enjoys in the enactment of legislation. All that a President can do is to recommend legislation to Congress and to rely on his political party to carry out his recommendations. Neither the President nor any member of his Cabinet has the right of addressing the House or the Senate in support of a measure to which the administration may be pledged -a constitutional difference-disadvantage it sometimes seems, as contrasted with British government-which must be kept in mind when it is recalled that it took six years of effort at Washington to carry the reciprocity measures of 1854 . 
But Pierce's message to the new Congress, which assembled in December 1853, at last brought the end in sight. Even in the former Congress some little progress had been made. ${ }^{1}$ A resolution had also been reported from one of the House committees requesting the President to arrange by treaty the questions connected with the fisheries on the coasts of British North America; the free navigation of the St. Lawrence and the St. John rivers; the export duty on American lumber in the Province of New Brunswick; and reciprocal trade with British North America, according to the principles of liberal commercial intercourse. Breckinridge, who reported this resolution to the House, unsuccessfully appealed for the suspension of the rules in order that immediate action might be taken on it. ${ }^{2}$ In the session of 1853, again, nothing definite was accomplished. The report from the committee, however, had the effect of bringing the question in all its bearingstrade, canals, free use of the St. John river to American lumbermen, and the fisheriesbefore the people of the United States; and when Pierce, in his message of December 5, 1853, reported that negotiations had been opened with Great Britain, with a fair prospect of a favourable result, it was well and generally known what lines the proposed treaty was to follow.

1 Cf. Congressional Globe, February 22, 24, 1853.

2 Ibid. March 3, 1853. 
Following Pierce's message, a joint resolution similar in terms to that which Breckinridge had reported to the House in March 1853 was introduced in the House and the Senate. The arguments for and against were on the lines of those in previous sessions; especially those in 1853 , when much stress was laid on the difficulties due to Great Britain's attitude towards the fisheries. In the House the resolution was adopted with but little delay. Progress was much slower in the Senate; but in the end the resolution was adopted. Among the influences that led to its adoption was the desire to avoid trouble over the fisheries; the advantages offered to the New England states in which there were manufacturing industries; to the state of New York, with its interest in lake and St. Lawrence navigation; and to the grain-growing states of the Middle West. Southern senators who, in 1853, constituted the pivotal section of the Democratic party which was then dominant at Washington, ${ }^{1}$ were by this time in favour of reciprocity, because they feared that unless trade conditions were improved in Canada the annexation movement of 1849 might become serious. If the British North American Provinces should come into the Union they feared that the balance of power at Washington between the slave states and the free states would be jeopardised.

Between 1854 and the outbreak of the War

1 Cf. Stanwood, American Tariff Controversies, i. p. 135. 


\section{PROTECTION IN CANADA сн.}

of the Rebellion in 1861, Toombs of Georgia admitted that this was one of the motives that induced senators from the South to vote for the treaty in 1854. Collamer of Vermont, in assailing the treaty in 1865 , told the Senate that he had publicly charged the southern senators with this motive. "I plainly stated," he said, "that this was the motive with which the treaty was made-with a view to quiet the people of Canada, and prevent their annexation to the North, which might disturb the balance of power of our southern friends; and Mr. Toombs, then sitting on the other side of the chamber, bowed very low to me, and said, "We have got the treaty. They have been quieted." "This," added Collamer, "was never denied. Indeed, they thought the ingenuity with which they concocted it was rather a feather in their caps."

Southern senators were also conciliated in the session of 1853-54 by the inclusion of cotton, rice, tobacco, turpentine, tar, and pitch ${ }^{2}$ in the schedule of articles that were to be admitted duty free. The treaty also gained some support in Congress from the fact that in 1853-54 protection in the United States was almost extinct as a political force, and that there was a well-nigh universal expectation that the arrangement for reciprocal trade with Canada was to be a first step towards free trade-that the tariff barrier along the

1 Congressional Globe, January 11, 1865.

${ }^{2}$ Cf. Stanwood, ii. p. 134. 
northern line of the country was soon to be broken down. ${ }^{1}$

Mr. Stanwood, the sympathetic historian of protection in the United States and the biographer of Blaine, concedes that this was the position at that time $;^{2}$ and notwithstanding occasional speeches like that of Fuller of Maine, who objected to the inroad that reciprocity would make in the protection accorded by the tariff of 1846 to the lumber industry, ${ }^{3}$ a study of the Congressional Globe from 1848 to 1854 brings out the temporary weakness of the protectionist movement emphasised by Stanwood in the chapter on the reciprocity treaty.

In surveying the influences that finally brought about the adoption of the joint resolution by the Senate, something must be allowed for the effect of the concession made to the lumbermen of Maine in connection with the export of logs from St. John, New Brunswick. Some of the streams of Maine fall into the magnificent St. John river, which, with its beautiful estuary, is wholly in British territory. Logs are floated down the Maine rivers into the St. John. There is no other practicable way of getting them out of the forests of Maine, which lie within the St. John watershed; and the provision in the treaty that logs belonging to American lumbermen should no longer be liable to an export duty imposed by New Brunswick, was one of much value

1 Cf. Stanwood, ii. p. 136.

3 Cf. Congressional Globe, February 22, 1853. 
to the Maine lumbermen, and to some extent offset the new competition which they anticipated in their home market from the Maritime Provinces.

The treaty, which was signed on June 5, 1854 , proved to be of great advantage to all the British North American Provinces. But the combination of circumstances that had secured its adoption-and in particular the pressure brought to bear on Washington in connection with the fisheries and the attitude of the southern senators-gave no guarantee of permanence beyond the ten years for which the treaty was to last; and in later years: in the seventies, when Canada again asked for reciprocity, when the South was no longer in the saddle, when the influence of New England and the Middle West was dominant at Washington, the fisheries episode, the protectionist and National Policy legislation of Cayley and Galt between 1854 and 1859, and the attitude of England, Canada, and Cape Colony during the Civil War,-all rankled in the minds of the American people, and told against a renewal of the neighbourly and beneficial trade relations which existed between the two countries from 1854 to $1866 .^{1}$

1 Cf. Larned, Report on the State of Trade, 1871, p. 29 ; Stanwood, ii. pp. 134-138 ; Blaine, Twenty Years of Congress, ii. pp. 620, 621 ; Lincoln's Message to Congress, December 6, 1864 ; Memoirs of John A. Dix, ii. pp. 108-116 ; Hatch, Report on Reciprocity, Executive Documents, H. of R., 1859-60, No.96, pp. 5-10. 


\section{CHAPTER V}

\section{RECIPROCITY : THE ABROGATION OF THE TREATY. $1854-1866$}

I was one of those who, at the time this treaty was adopted, looked upon it as one of those healthful indications of the application of Christian principles to the legislation and diplomacy of nations. I believed it was an onward path in the march of national morals-indicative of a better, a purer, and a higher state of things than had heretofore prevailed.Senator HALE of New Hampshire.

BY the treaty of 1854 inhabitants of the United States had, in common with British subjects, liberty to take fish of every kind, except shell-fish, on the sea coasts and shores, and in the bays, harbours, and creeks of Canada, New Brunswick, Nova Scotia, and Prince Edward Island, without being restricted to any distance from the shores, with permission to land for the purpose of drying their nets and curing their fish. The new privileges in extension of the rights of American fishermen under the treaty of 1818 were restricted to sea fisheries; salmon and shad being reserved for British fishermen. 
The navigation of the St. Lawrence and the Canadian canals was open to American shipping, subject to the same tolls as were levied on Canadian shipping. No export duties were to be levied on American lumber floated down the St. John river when it was shipped to the United States; and, finally, there was a list of articles which were to be free of custom duties in both countries. ${ }^{1}$

Since this list was first embodied in the reciprocity bill, which Dix advocated in the Senate in $1848,{ }^{2}$ it had been greatly extended. Several of the additions-for instance, cotton and turpentine and unmanufactured tobacco-were made at Washington for the benefit of southern interests; but most of them, and especially coal and fish, were due to the decision that reciprocity should apply not only to Ontario and Quebec, but to all the British North American colonies, including Newfoundland. Accordingly, while the treaty was in operation it established free trade between the United States and British North America in the following specified articles, and in these only: grain, flour, and bread-stuffs ; animals of all kind ; ashes ; fresh and salted meats; timber and lumber of all kinds, round, bent, sawed, and unmanufactured; cotton-wool; seeds and vegetables;

1 H. Hertslet, Treaties and Conventions, ix. pp. 998-1002.

2 The original list was : grain and bread-stuffs of all kinds; fruit, animals, hides, wool, tallow, horns, salted and fresh meats ; ores of all kinds of metal ; timber, staves, wood, and lumber of all kinàs. 
undried and dried fruits; fish of all kinds; products of fish and of all creatures living in the water; poultry, eggs; hides, furs, skins or tails, undressed; stone or marble in its crude and unwrought state; slate; butter, cheese, and tallow; ores of metals of all kinds; coal; unmanufactured tobacco; pitch, tar, and turpentine; firewood; plants, shrubs, and trees; pelts; wool; rice and broom corn; barks; gypsum, ground and unground; wrought and unwrought burr and grindstones; dye-stuffs ; flax, hemp, and tow, unmanufactured, and rags. ${ }^{1}$

Beyond all doubt, reciprocity was of great advantage to both countries during the twelve years while the treaty was in operation. On both sides of the border line this has always been admitted. ${ }^{2}$ It is equally certain, however, that most advantage accrued to the British North American colonies. This followed from the fact that the treaty admitted a country with a population of not more than three millions, chiefly engaged in agriculture, fishing, mining, and lumbering, to a free market in a country with thirty-three or thirty-four millions, a considerable proportion of whom were engaged in commerce and industry, and in which the per capita purchasing power was larger than in the British colonies. So far as natural products were concerned, the Elgin-Marcy Treaty gave Canada all the

1 Hertslet, Treaties and Conventions, ix. p. 1000.

2 Cf. Haynes, Reciprocity Treaty with Canada of 1854-56, p. 56. 
сн.

advantages of commercial union ; while Canadians were free from the heavier fiscal burdens of the United States-burdens which were onerous indeed during the last four or five years of the treaty, when the Government at Washington was engaged in the tremendous task of suppressing the rebellion in the revolted southern states, and hundreds of thousands of men were being drafted for the war.

It is not my purpose to go into statistical details of the trade under the treaty. The interpretation of these statistics has long been a matter of much controversy. The Canadian point of view of the figures can best be studied in the correspondence that passed between Thornton, British Minister at Washington, and Derby, Secretary of State for the Colonies in Gladstone's 1868-74 administration, when Thornton and George Brown, during the Mackenzie régime at Ottawa, were negotiating another treaty in 1874 . This treaty was accepted by the Governments of Great Britain and Canada and of the United States, but was refused ratification by the Senate at Washington. The same statistics, with lucid explanations by the foremost expert on this subject in Canada, can also be found in Mr. John Charlton's "Trade Relations with the States," a well and clearly-written series of articles tracing the history of Canadian trade with the United States from the treaty of 1854 to the abortive Joint High Commission of 1898-99, 
which was published in the Globe of Toronto in $1906 .^{1}$

The American view of the statistics of exports and imports under theElgin-Marcy Treaty is given in much detail in Larned's report of 1871 - the report in which Larned insisted that, under the arrangement of 1854-66, there was a large excess of liberality on the side of the United States in the terms of trade; and "that in return for this liberality the Canadian tariff, as it was from time to time amended between 1854 and 1864, grew steadily more illiberal and non-reciprocal."

Only a few figures need be cited to show how enormously the treaty stimulated exports from Canada to the United States. In 1854 the exports of lumber were of the value of $\$ 753,000$; in 1865 the value was $\$ 4,887,000$. Live stock exports in 1854 were $\$ 73,000$; in $1865, \$ 5,503,000$. The exports of flour in 1854 were $\$ 1,792,000$; in $1865, \$ 2,970,000$. Exports of barley increased from $\$ 55,000$ to $\$ 4,093,000$; and of oats from $\$ 37,000$ to $\$ 2,216,000$ in the same time. The increase in the exports of fish and fish products was from $\$ 1,004,000$ in 1854 to $\$ 2,213,384$ in 1865. The export of coal from Nova Scotia increased with the general increase of trade

1 Charlton on Trade Relations, Globe, June 2; The Forgotteu High Commission, June 23; and Trade Relations with the United States, June 30, 1906. Mr. Charlton, at the time of writing (July 1907), is at work on an autobiography in which the valuable articles that appeared in the Globe in June 1906 are to be given a more permanent form.

${ }^{2}$ Cf. Larned, Report on Canadian Trade, pp. 12.14. 
124 PROTECTION IN CANADA сн.

between the two countries; and in 1865 the value of coal exported, chiefly from Pictou, Liverpool, and Sydney, was $\$ 1,223,000$, as compared with $\$ 254,000$ in 1854 . Exports of butter in 1854 were $\$ 126,000$; in 1865 , $\$ 668,000$. In 1854 exports of wool were $\$ 69,000$; in $1865, \$ 1,527,000$. Hides and skins in 1854 were $\$ 34,000$; in 1865 , $\$ 228,000$. Furs and fur skins in 1854 were $\$ 13,900$; in $1865, \$ 214,000$. Potatoes in 1854 were $\$ 88,000$; in $1865, \$ 147,380$. Provisions in 1854 were $\$ 4400$; in 1865 , $\$ 851,000$. $^{1}$

The last six years of the treaty were by no means normal. During four of them war prevailed in the United States; two or three million men were withdrawn from productive work for service with the armies, and prices were greatly inflated owing to the war, and owing to the use of paper currency. These conditions make it difficult to determine what the value of the treaty would have been to Canada had there been no Civil War. But when all allowance has been made for the abnormal conditions of 1860-65, the statistics of trade for 1854-66 abundantly justified all the efforts that the Governments of Canada and of Great Britain made between 1846 and 1854 to secure reciprocity; and the recollection of the effects of reciprocity has also fully warranted all the efforts which were made by Canada and Great Britain between 1870 and

${ }^{1}$ Cf. Larned, Report on Canadian Trade, p. 14. 
1899 to bring about a return to some such conditions as those under the Elgin-Marcy Treaty, which were so abundantly beneficial to the British North American Provinces. Even to-day, when, owing to conditions which will be discussed later, reciprocity between Canada and the United States is more remote than at any time since 1866 ; when it is almost as remote as annexation, and quite as remote as any tariff concessions to Great Britain beyond those of the preference enactment of 1897 , reciprocity is still a pleasant tradition, a reminiscence of prosperity, with the farmers of Quebec and Ontario, as was frequently brought to the notice of the Tariff Commission at Montreal and Toronto, and especially at the smaller cities of Ontario, between Hamilton and Windsor, on the Detroit river.

Mr. Stanwood, who is no friend of the reciprocity arrangement of 1854-66, ungrudgingly concedes that "access to the inshore fisheries of British North America was a valuable privilege to New England." "It was a privilege," he writes, "of which the fishermen made light ; for they had always declared that they asked nothing more than security in the international right to fish at a distance of a marine league from the shore. It may be that the fishermen would have been satisfied with such rights as were theirs by the law of nations as interpreted by American Secretaries of State; yet it is to be conceded that whenever the greater privileges have been 
theirs, they have taken full advantage of them." 1

It is of record also that another New England industry gained enormously by the treaty; for in 1866, when, as a result of its denunciation by the United States, the tariff bars at the American customs-houses had again been put up against imports from Canada, a return to the old condition was strongly pressed at Washington by the woollen manufacturers of New England. The United States Government and Congress was then informed by the woollen men-whose trade organisation, the Association of Wool Manufacturers of the United States, has long had its headquarters at Boston-that the manufacture of worsted in the United States began with the free importation of Canadian fleece under the treaty of reciprocity. In 1866 it was estimated by experts in the trade that the entire production in the United States of wools suited to the manufacture of worsted goods was not more than a hundred and forty thousand pounds; while in Canada, at this time, the production of these wools was estimated at about six million pounds. The call for wool at the worsted mills in the United States during these years was two million nine hundred thousand pounds; and when they realised that the old arrangement with Canada had come to an end, the New England woollen men complained that " a duty on Canadian

1 Stanwood, ii. pp. 134-136. 
wools would crush an industry which has already assumed a truly national importance, and has advanced with a rapidity unexampled in any branch of American textile manufactures." 1

With this memorial from the National Association there were affidavits from individual manufacturers, setting out the loss and inconvenience which would result to them from the abrogation of the treaty of 1854 . "Worsted yarns of the finer grades," reads one of these statements, "were made in the United States only to a very limited extent prior to 1860 or 1861, except for delaines, the yarns manufactured prior to that being principally designed for carpets. The introduction of the manufacture of the finer yarns is due to the command of Canadian wools admitted free under the reciprocity treaty. Yarns for the weft of worsted stuffs are made of long lustre combing wools, such as are grown upon sheep known as Leicestershire, Cotswold, and similar breeds raised in England and Canada." ${ }^{2}$ Manufacturers of worsted braids also submitted similar affidavits $;^{3}$ which, with the general memorial of the National Association of Wool Manufacturers, furnish abundant proof that the fishing interests of Gloucester, Portsmouth, Portland, and Lubec were by no means the only New

1 Cf. Memorial from the National Association of Wool Manufacturers in the United States, 1866.

${ }^{2}$ Affidavits made January 13, 1866, State of Massachusetts, county of Suffolk, the county in which Boston is situated.

3 Ibid. 
England industrial interests which profited largely from the neighbourly trade relations with Canada of 1854-66.

Most of the New England states, as well as New York and the other states bordering on the Great Lakes, profited from free lumber from Canada; for after the treaty was at an end these imports paid duty at the rate of twenty per cent. Every New England railway company reaching Portland, Portsmouth, Boston, New Bedford, or New Haven, had the advantage of free coal from Nova Scotia; so had the manufacturing industries in the thickly populated regions of Massachusetts and Connecticut that are near to tide water. The removal of Canadian export duties on American logs brought down the St. John river was also a concession to an important Maine industry; and until the Parliament of the United Provinces in 1859 imposed differential tolls on the Welland and St. Lawrence canals, and allower drawbacks of ninety to ninety-five per cent on American vessels bound to Montreal, as against the dues paid by an American vessel bound from one United States lake port to another American port, the privileges of the Welland and St. Lawrence canals were much valued at American ports on the Great Lakes.

The advantages of reciprocity were not so widespread, not so uniformly and generally shared in the United States as they were in the British provinces; for every province east 
of Lake Huron, that since 1867 has been of the Dominion of Canada, enjoyed enormously increased trading facilities from the wide inlet into the markets of the United States made by the Elgin-Marcy Treaty. Even had there been no civil war to dislocate trade in the United States from 1861 to 1865 , geographical conditions would have prevented nearly twothirds of the states of the Union from obtaining direct and obvious advantages from reciprocity. The advantages of the treaty on the American side of the border were sectional. It was impossible for them to be as general as they were in Canada. But to the sections of the United States that came within the area of direct advantage-New England, New York, and the other states that border on the Great Lakes-there is no lack of proof that there were advantages of easier trade and transport conditions, and larger opportunities for the fishery industry of New England, in return for the tariff concessions which admitted the natural products of Canada duty free into the United States.

Not infrequently has it been asserted that the United States in 1865 denounced the treaty of 1854 in a mood of irritation at the attitude of England and Canada towards Lincoln and his Government during the War of the Rebellion. ${ }^{1}$ The mood of the United

1 "To the anger which the behaviour of a party in England had excited in America, Canada owes the loss of the reciprocity treaty, and the bitter proof which she has since had of Lord Elgin's saying, that free navigation and reciprocal trade with the States are indis- 
States towards England and Canada at this time undoubtedly seriously influenced the movement against reciprocity when it reached its final stages in Congress. But almost as many causes led to the ending of the treaty, just as soon as the United States was free to act, as had led to Elgin's triumph in 1854 . Some of these causes were inherent in the treaty itself. Others lay in the circumstances which attended its acceptance by the United States.

Canadians were early alive to the adverse conditions which deprived the treaty of any guarantee of permanence. In Ontario it was soon realised that the great lack from the American point of view was that the treaty did not provide for the free admission of American manufactures. Isaac Buchanan, as early as 1859 , admitted the danger from this lack. Only a year before, Buchanan, as the dominating influence in the Association for the Promotion of Canadian Industry, had induced Cayley, Inspector-General in 1858, to give protection in the Canadian tariff to several manufacturing industries. ${ }^{1}$ This was one of the Canadian National Policy and protectionist pinpricks of which the United States

pensable to put her people in as good a position as their neighbours. If Great Britain can with justice say that she has paid heavily for the defence of Canada, Canada can with equal justice say that she has paid heavily in the way of commercial sacrifice to the policy of Great Britain."-Goldwin Smith, Canada and the Canadian Question, p. 141. Cf. also Haynes, Reciprocity Treaty with Canada of 1854, p. 57 .

1 Cf. Buchanan, Britain the Country versus Britain the Empire, p. 35 ; Globe, April 15, 1858. 
complained when the fate of the treaty was in the balance in 1864 and 1865. Buchanan was largely responsible for it. After the enactment of the tariff of 1858 he prided himself on the fact that the protectionist movement in Canada was making headway; yet in 1859, in addressing his constituents at Hamilton, he advocated the extension of the reciprocity treaty to manufactures, and declared himself in favour of carrying reciprocity further, so as to establish between the provinces and the United States an American Zollverein-" each country adopting the policy of unlimited free trade with each other, and the same protection to domestic manufactures." 1

Notwithstanding concessions to the protectionists which were made in the Canadian tariffs of 1858 and 1859-concessions which in 1859 brought Galt, who was then InspectorGeneral, into an acrimonious correspondence with Newcastle, then Secretary for the Colonies -it was intimated to the United States Congress in 1863 by the Government of the United Provinces that it was willing to unite in seeking to find means for extending the number of articles for free admission into Canada. $^{2}$ In 1863 also, at a public meeting in Toronto, Buchanan elaborated the scheme for an American Zollverein which he had outlined in his address to the electors of Hamilton

1 Cf. James W. Taylor (St. Paul, Minnesota), Report on Reciprocity, Executive Documents, 1859-60, No. 96, p. 58.

${ }^{2}$ Cf. Congressional Globe, January 12, 1865. 
in 1859. "The preservation of this reciprocity with the United States," said Buchanan, in his speech of December 1863, "is not only to the interest of the farmers, and through them of all others in Canada. It is of interest to the British Government, as without it Canadians are left in a position to be much benefited by annexation to the United States. And this reciprocity treaty can only eventually be secured and rendered permanent by the British Government adopting a policy which would look without jealousy on the decentralisation of the manufacturing power of the Empire."

To preserve the Empire, Buchanan argued, Britain must yield the selfish principle of centralising. England could never hope for free trade in manufactures with the United States ; but no doubt the United States would be prepared to extend the reciprocity treaty with Canada. Then all customs barriers at the border would be thrown down; "which done," continued Buchanan, "the Englishman, by coming to Canada and manufacturing his goods at our endless water-powers, will be able to save the twenty-five per cent charged on the same goods going direct from England to the United States; and hundreds of millowners, now in uneasy circumstances in England, would, under such an arrangement, immediately transfer to Canada their maehinery and hands, to the infinite benefit of the population thus removed and to the aggrandisement of the Empire." 
"The natural policy of Canada," Buchanan further argued, "is clearly seen, therefore, to be the establishment of an American Zollverein such as exists in the German States. Under this the United States and Canada would neither of them levy any customs taxes on their frontiers, but only at the seaports from Labrador to Mexico-the same duties being levied, and each country getting its share in proportion of its population. Let it therefore be resolved that, for our commercial system, this principle should be adopted by Canada of an American Zollverein ; or in other words, free trade with the United States, but not with Europe." "Why," asked Buchanan, "should England be jealous or oppose such a policy? Is not Canada just England in America? If Canadians get an advantage, they wish no monopoly of it. Every Old Countryman is welcome to come and share it."

The reciprocity treaty had been a relief to Canada; but Buchanan foresaw that it might be only a temporary one; for by December 1863 the treaty was being much assailed in the United States as a one-sided bargain, and a bargain the spirit of which had not been faithfully observed by Canada; and Buchanan's final plea at this Toronto meeting was that, as a necessary consequence of the free trade legislation in England in 1846, Canada would be compelled to require England to assent to the establishment of an American Zollverein, and to Canada being made neutral territory 


\section{PROTECTION IN CANADA сн.}

in the event of a war between England and the United States. ${ }^{1}$

The first discussion of the operation of the treaty of 1854 at Washington was in 1858, when it was proposed that it should be so extended by the joint action of the United States and Great Britain as to include hay and hops in the list of duty-free articles. ${ }^{2}$ Nothing resulted from this movement, which was distinctly friendly to reciprocity; but after the Cayley and Galt tariffs of 1858 and 1859 had gone into effect in Canada, the United States Government instituted an inquiry to ascertain how reciprocity was working from an American point of view. Two commissioners-Israel T. Hatch of Buffalo, New York, and James W. Taylor of St. Paul, Minnesota-were appointed, and in May 1860 their reports were submitted to Congress.

Hatch's report, which was the more detailed and searching, was distinctly unfavourable. $\mathrm{He}$ asserted that the spirit of the treaty had been perverted by Canada, and cited schedules from the Canadian tariffs in proof of his statement that every year since 1854 "a new tariff has been enacted, and each of them has inflicted higher duties on the products of American labour." The schedules quoted by Hatch showed that while in 1855 the Canadian duty on molasses was 16 per cent, in 1859-

1 Buchanan's Speech at Toronto, 1863, edited by H. T. Morgan, pp. 19-21.

2 Cf. Congressional Globe, June 12, 1858. 
after the enactment of the Galt tariff-the duty was 30 per cent. In these four years, 1855-59, the duty on refined sugar had been advanced from 32 to 40 per cent; on boots and shoes from $12 \frac{1}{2}$ to 25 per cent; on harness from $12 \frac{1}{2}$ to 20 per cent; on cotton goods, iron and manufactures of iron, and silk goods, from $12 \frac{1}{2}$ to 20 per cent; and on woollen goods the duty had also been increased from $12 \frac{1}{2}$ per cent to 20 per cent.

"The tariff of 1859," Hatch maintained, "was avowedly based on an isolating and exclusive policy. It was supported on this ground alike by the ministerial organs in the press, by petitions in its favour, and by members of the Colonial Parliament. After securing our free market for all Canadian productions, the advocates of the tariff of 1859 argued that it was the interest of Canada to become independent of all other countries, and to employ their own ships and their own people, thus keeping in the country all that is now paid to the United States."

Great pains were taken by Hatch to ascertain how Canadians, and especially the people of Ontario, regarded Galt's protectionist tariff. He reported that "the Canadian people do not feel very easy under their recent legislation, as to its effect on the United States; and many of their public men, and some journals, speak of it as furnishing just grounds to the United States for annulling the treaty." The boards of trade in the chief Canadian 
Сн.

cities, he stated, had protested against Galt's tariff, and condemned it as " uncalled for and unwise," and as "calculated to affect the existing pleasant commercial relations between Canada and the United States."

Hatch also complained that Canada was taxing manufactures from the United States to pay for canals and railways which were to come into competition with American railways and canals; and he asserted that when the Canadian Government established a system of ad valorem duties, levied in such a manner as to discriminate against the commercial and shipping interests of the United States, and advanced the duties on American manufactures by the tariff of 1859 " to an almost prohibitory degree," it "must have known that if such Canadian duties had existed, or been expected, at the time the treaty was made it could never have obtained the assent of Congress." He was convinced that the change from specific to ad valorem duties recently made in the Canadian tariff-a change by which duties were charged on the value of goods at the place of purchase-was intended to divert trade from New York and Boston to Montreal ; and after emphasising the advantages that were accruing to Canada under the treatyhow it had ended the movement for annexation, and made farms in Ontario and Quebec as valuable as farms in the United Stateshe asserted in most unequivocal terms that Canada was not giving the United States what 
would nowadays be described as a square deal.

"Viewed as a question of national integrity," Hatch wrote, on this aspect of Canadian policy, "the conduct of the Canadian Parliament in thus taxing the products of American industry almost to their exclusion from the province must be pronounced to be a violation not only of the letter and the spirit of the treaty, but of the amity and good faith in which it was conceived, and without which all international obligations are unavailing." Hatch was so strongly impressed with the lack of good faith towards the United States shown in Galt's protectionist policy, so confident that the United States was not getting a square deal, and that Canada would not concede a fair deal, that he regretted that the Elgin-Marcy Treaty had still five years to run, and that it could not be abrogated by some quicker method than that of waiting until 1864 for its denunciation by the United States. ${ }^{1}$

Taylor of St. Paul, whose report embodied the opinion as to the treaty in the states at the head of the Great Lakes, admitted defects from an American point of view, but was in favour of amending rather than ending the arrangement with Canada. He reported that west of Buffalo, on the line of the Lakes, there was only one sentiment, and that was

I Cf. Hatch, Report on Reciprocity, Exccutive Documents, H. of R., No. 96, pp. 5-25. 
CH.

of hostility to the abrogation of the treaty. He looked ahead to the filling up of the Canadian west-to trade which the states of Minnesota and Michigan might do with what are now the provinces of Manitoba, Alberta, and Saskatchewan-and urged the enlargement of the treaty as soon as possible, so that it might " merit the designation of a Zollverein or customs union." Taylor quoted an editorial article from the Tribune of Detroit, in which it was asserted that the increased Canadian duties had driven no manufacturers from Michigan into Ontario ; that these duties up to that time had not injuriously affected manufacturers in Michigan; that reciprocity had found employment for a large number of vessels of the port of Detroit; and that trade under the treaty was mutually beneficial, with a balance between 1854 and 1859 of over seven and a half million dollars in favour of the state of Michigan.

From the proceedings of the Board of Trade of Chicago, Taylor quoted a resolution in which surprise and alarm were expressed at the movement for the abrogation of the treaty; and the burden of his report was that if there was a necessity for a revision of the treaty, the revision should be in accordance with " the principle which the United States has always advanced - freedom and not restriction of commercial intercourse." 1

1 Cf. Taylor, Report on Reciprocity, Executive Documents, $\mathrm{H}$. of R., 1859-60, No. 9, pp. 47-58. 
By 1860 the movement for protection in the United States was no longer in the dormant condition described by Mr. Stanwood when he is explaining how it was that the reciprocity treaty was accepted by Congress in 1854. The Republican party was by this time in existence. Its organisation and strength brought about the election of Lincoln, in November 1860 . The party had by this time committed itself to the policy which it pursued from 1861 to the Dingley Act of 1897the most protectionist tariff ever enacted at Washington-and these two reports to Congress in May 1860, the one from Buffalo, already a centre of manufacturing, and the other from St. Paul, where, in 1860, there was little or no manufacturing, indicated the popular attitude towards protection in these two widely-separated sections of the United States in the last year of Buchanan's term as President.

No definite action was taken by Congress in 1860 on the Hatch-Taylor reports. Their widespread publication, however, soon began to have an influence on public opinion, especially in the State of New York, where trade relations with Canada were dislocated by the higher duties in the Canadian tariff, by the change from specific to ad valorem duties, and by the system of differential tolls on the Canadian canals. Dix and $\mathrm{M}^{\circ}$ Clelland, who had worked so strenuously in Congress for the reciprocity bills of 1848 and 1849, were both, it will be 
remembered, from the State of New York. But by 1860 it was being realised in that State that reciprocity was not meeting expectations which had been entertained between 1848 and 1854. The centres of trade and transport in Northern New York-Albany, Rouse's Point, Ogdensburg, Oswego, Rochester, Lewiston, Buffalo, and Dunkirk-are nearer to the centres of trade and shipping in Ontario and Quebec than similar centres in any other state within the area of advantage from reciprocity.

Boston and the New England centres of trade and manufacturing felt the influence of the higher duties and the change in the mode of levying duties in Canada. But New York State soon felt the influence of all three changes - higher duties, ad valorem duties, and differential canal tolls. Merchants, shippers, and manufacturers were also sufficiently near to Canada to realise what these three changes portended-in sufficiently close and frequent business communication to understand what Cayley and Galt were aiming at when in 1858 and 1859 their governments began to enact National Policy measures. It is not surprising, therefore, that these National Policy pimpricks should more quickly have aroused New York than the states farther from the border which were not interested in Lake and St. Lawrence shipping. Hatch was expressing Northern New York sentiment when he wrote his report of May 1860; and 
it was at the instance of the Legislature of the State of New York that the reciprocity treaty came up again in Congress in April 1862.

American state legislatures, through their Committees on Federal Relations, and by joint resolution, are able quickly to bring matters of moment through the representatives of their state at Washington before Congress, or to the attention of the United States Government. There survives in state legislatures a custom something akin to the old usage in England by which constituencies were wont to instruct their members in the House of Commons $;^{1}$ and in the early months of 1861 this custom was followed by the Legislature at Albany to focus the attention of members of the New York delegation at Washington on the unfair working of the reciprocity treaty with New York's neighbours on the northern shores of Lake Ontario and the St. Lawrence. A joint resolution was adopted by the House and the Senate calling upon the senators and representatives from New York at Washington to urge Congress, either by the appointment of commissioners to confer with persons appointed on behalf of Canada, or by such other means as might seem expedient, to protect the interests of the United States from the unequal and unjust system of commerce then existing, and to regulate commerce and navigation between British North America

${ }^{1}$ Cf. Porritt, Unreformed House of Conmons, i. pp. 263-268. 


\section{PROTECTION IN CANADA сн.}

and the United States in such a manner as to render the same reciprocally beneficial and satisfactory, as was intended and expressed in the treaty of 1854 .

In setting forth the reasons why the treaty was unsatisfactory the Legislature complained of the heary duties imposed on manufactures "with the intention of excluding the United States from the Canadian market"; asserted that Galt, who about this time had taken the official title of Minister of Finance instead of that of Inspector-General, had avowed this as the policy of Canada; complained further that there had been legislation in Canada, with the same official avowal, imposing discriminating tolls on the canals - "all," it was added, "in favour of an isolating and exclusive policy against our merchants and forwarders," and intended to destroy the natural effect of the treaty, and contrary to its spirit. The resolution also recalled Hatch's report of 1860 , and in particular a statement therein that complained of the "gross inequality and injustice existing in our present intercourse with Canada, subversive of the true intent of the treaty, owing to subsequent legislation in Canada."

Retaliatory measures were not asked from Congress by the New York Legislature, because "the first effects of a system of retaliation or reprisal would injure that portion of Canada known as the Upper Province, whose people have never failed in their efforts to secure a 

permanent and just policy for their own
country and ourselves." 1

The last paragraph in the New York resolution, that referring to Upper Canada, is significant. It demonstrates the various influences which led to the abandonment of the treaty in 1865; and also where some of the most important of these irritating influences had their origin. The protectionist movement in Ontario and Quebec, of which at this time Buchanan was the popular leader and Galt the foremost official protagonist, was in part responsible for two of the changes in Canada's trade and fiscal policy of which New York State complained. But it was well known at Albany, in 1861, that Montreal interests - shipping, trading, and manufacturing-were usually dominant in determining trade measures in the Canadian Parliament; and also that unavailing protests were often made from Toronto against the dominance of those Montreal interests. At later stages of the movement in the United States for the mending or ending of the Elgin-Marcy Treaty there were many complaints that Canada had not played the game in the spirit of the treaty. These were, however, usually accompanied by statements that Americans had no grievances against New Brunswick, Nova Scotia, Prince Edward Island, or Newfound-

1 The joint resolution was adopted by the Senate at Albany, on March 1; by the House of Assembly on April 12, 1861.-Laws of the State of New York, 1861, p. 826. 
CH.

land-statements that may be taken as proof that the Maritime Provinces had lived loyally up to their obligations of 1854 in respect of the fisheries and the common use of the St. John river by American and Canadian lumbermen. ${ }^{\mathrm{T}}$

Had there been no war between North and South, with the easy escape of the Alabama from the Mersey in 1862, and the inroad of secessionist raiders from the province of Quebec into St. Albans, Vermont, in December 1864, ---had no bitterness of feeling been aroused between the United States and Great Britain in consequence of these and other episodes of the war, the Elgin-Marcy 'Treaty, in the form in which it was signed in June 1854, would not have survived a day longer than it did. Even before Lincoln had become President, the demand in the United States was that Canada should restore the scale of duties on manufactures existing when the treaty was ratified, on penalty of abrogation $;^{2}$ and all responsibility for this discontent in the United States, up to May 1860, lay with Cayley and Galt - chiefly with Galt, who carried the National Policy in Canada much farther, and gave it more manifold applications than Cayley had done in the tariff which he enacted in 1858 at the instance of the Association for the Promotion of Canadian Industry.

The New York resolution was adopted in

1 Cf. Executive Documents, 1862, No. 22, pp. 18-20.

${ }^{2}$ Cf. Taylor, Report on Reciprocity, p. 53. 
April 1861. It was April 1862 before it came up in Congress. Spaulding of Buffalo then introduced a resolution in the House of Representatives in accordance with the terms of the Albany instructions to the New York State delegation at Washington. It was a joint resolution, which was to be adopted by the House and sent to the Senate for concurrence, as is the usage in matters of this nature in Congress. It called upon and authorised President Lincoln to appoint commissioners "to negotiate a new treaty with the British Provinces based upon the true principles of reciprocity" ; and also authorised the President to give the necessary notice to terminate "the present unsatisfactory treaty." 1 The Spaulding resolution was referred to the House Committee on Commerce, which reported in favour of the appointment of commissioners; on the ground that reciprocity was conducive to the interest of both the United States and Canada, and was the proper basis of intercourse for all time to come. ${ }^{2}$ It was this report that was the basis of all discussion of reciprocity in Congress in 1862, 1863 , and 1864 .

In these years the friends of the treaty in and out of Congress ${ }^{3}$ directed all their efforts to securing amendments in it. They laid

1 Congressional Globe, April 28, 1862.

2 Ibid. January 11, 1865.

3 Outside support of the treaty came chiefly from St. Paul and Detroit Chambers of Commerce.-Cf. Congressional Globe, January 11, 1865 . 
much emphasis on what they regarded as proofs that Canada was willing to give the United States a square deal, and that the British Government would use its influence to this end. They recalled a resolution which had been before the Canadian Parliament in 1858, in favour of the extension of the principle of the treaty to manufactures. They laid mucl stress on a statement, made in 1859 , by Lord Napier, when he was British Minister at Washington, that he was prepared to submit proposals for the confirmation and expansion of free commercial relations between the United States and the British Provinces. ${ }^{1}$ Later on, in 1863, some importance was attached to an offer by the Canadian Minister of Finance of co-operation with the Committees of Commerce of the House of Representatives in finding means for extending the treaty. "The undersigned," the Canadian Minister then wrote, "feels every confidence that much greater scope could be given to the treaty without compromising on the one hand the revenue interests of the United States, or, on the other hand, the just claims to an equality in the Canadian market which belongs both of right and duty to Great Britain."

What the friends of reciprocity at Washington expected from Canada in the event of the treaty being confirmed and extended

1 Cf. Executive Documents, 1862, No. 22, pp. 5-9.

2 Cf. Correspondence quoted in debate in Senate, Congressional Globe, January 12, 1865. 
was set out in a report from the House Committee on Commerce in 1862 . "In admitting Canada to the commercial advantages she would enjoy if she were a state of this Union," reads a paragraph in this report, "we have a right to expect from her in return the same commercial privileges which each state of the Union confers upon the others." ${ }^{1}$

Questions arising out of the war monopolised the attention of Congress in 1862, 1863 , and 1864; and action on the resolution for the appointment of commissioners to amend the treaty was as dilatory as the progress of reciprocity bills through Congress had been from 1848 to 1854 . Between April 1861, when Spaulding urged the amendment of the treaty, and the end of 1864, the attitude of England and Canada towards the Government at Washington and the war had aroused much ill-feeling in the United States; and by few men in American public life was this feeling more strongly, while still calmly, expressed than by General Dix, who as Senator from New York had worked so hard in 1848 and 1849 for reciprocity with Canada.

"The most extraordinary feature in the domestic contest in which we are now engaged," said General Dix, when popular feeling against England was at its height, " is the unfriendly conduct of Great Britain. For the last twenty-five years our sympathies have been on her side in all her foreign and domestic

1 Executive Documents, 1862, No. 22, p. 9. 
dissensions and conflicts. When the Canadian rebellion broke out, the President, Mr. Van Buren, not only issued a proclamation prohibiting all citizens of the United States from taking part in the insurrection against the authority of the Government, but he sent a military force, under General Scott, to the frontier to see that the prohibition was enforced. When the insurrection broke out in India, the sympathy of our people with the British Government was nearly universal. Our press and our public meetings abounded in the most feeling expression of interest in the triumph of her arms. So in the Crimean War, the great mass of our citizens wished her success. What better evidence can be given of the unaffected kindness of feeling which prevailed throughout the northern and middle states than the triumphant passage of the Prince of Wales through them? It was only at Richmond that he met with rudeness and contumelious treatment."

"And yet," continued Dix, "from the very beginning of the domestic affliction which has fallen upon us, she has, secretly and openly, as far as she could venture, taken the side of the insurrectionists, recognising them as belligerents, and giving them moral support through nearly every one of her consulates in the United States. In doing so, she abandons every principle for which she has contended in times past. She gives her countenance and support to every social and 
political wrong which she has resented. What nation has been more steadily opposed to slavery than Great Britain, or has more frequently charged it upon us as a stain upon our national character, or called on us with more impatient earnestness to blot it out? And yet the insurrection comes from the slave states; it was got up for protection and extension of slavery, and because the northern states would not become parties to the dishonour for which we were so loudly denounced. Great Britain thus becomes the advocate of filibusterism, repudiation, slavery, and rebellion. What motive can be found but an unprincipled desire to break up the Union, and a willingness for the purpose of accomplishing that object to give her countenance to the very institution in our history which has given her and other nations of Europe the greatest offence." 1

After the St. Alban's raid and Lincoln's message of December 6, 1864, the discussions in Congress on trade relations with Canada took a new and decidedly unfavourable turn. "In view of the insecurity of life and property in regions adjacent to the Ganadian border by reason of recent assaults and depredations committed by inimical and desperate persons who are harboured there," wrote Lincoln, in reference to the raid of secessionists from Canada into Vermont, "I have thought it proper to give six months' notice that the

1 Morgan Dix, Memoir of John A. Dix, ii. pp. 108-116. 
United States might hold themselves at liberty to increase the armaments on the Lakes if they shall find it necessary." "I desire, however," added Lincoln, " to be understood, while making this statement, that the colonial author"ities of Canada are not deemed to be intentionally unjust or unfriendly towards the United States; but, on the contrary, there is every reason to expect that with the approval of the Imperial Government they will take the necessary steps to prevent new incursions across the border."

'The President's annual message, like the speech from the throne at Westminster, comes at the opening of the session. In 1864 the session opened on December 6, and on December 14 a joint resolution for the mending or ending of the treaty was sent to the Senate from the House for concurrence. It passed two of its stages on the same day. It was then sent to the Committee on Foreign Relations, of which Sumner of Massachusetts was chairman; and from the time Sumner was in charge the ill-feeling due to the attitude of England and Canada during the war came strongly into play. The committee reported against amending the treaty and in favour of its abrogation; and with this report before the Senate the fate of the Elgin-Marcy Treaty was sealed.

One of the warmest debates was on January 11, 1865, when Hale of New Hampshire

${ }^{3}$ Richardson, Messages and Papers of the Presidents, vi. p. 246. 
championed the treaty as vigorously as either Dix or Douglas had done before its adoption in 1854. Hale regarded the attack as highly disastrous to the best interests of the United States. He complained that the resolution before the Senate had not originated with the Committee on Trade or the Committee on Finance. He objected to the characterisation of the treaty as the "so-called reciprocity treaty." $\mathrm{He}$ expressed strong opposition to action by Congress until the commercial world of the United States had been heard from at Washington; and he denied that the extended privileges to New England fishermen were of no value. "I was one of those," said Hale, "who at the time this treaty was adopted looked upon it with great favour. I looked upon it as one of those healthful indications of the application of Christian principles to the legislation and diplomacy of nations. I believed it was an onward path in the march of national morals-indicative of a better, a purer, and a higher state of things than had heretofore prevailed. I believed so then, and I believe so now; and to my mind this proposition to abrogate the reciprocity treaty is a step back from the advancing civilisation of the present age to the dark ages of restriction which so long hampered the progress of nations." "Suppose the treaty is imperfect," continued Hale, "suppose its operation is not everything that we could wish it to be; and I do not contend that it is. I am willing to 
believe that there are some things about it that may be amended, and ought to be amended. Let me ask the Senator from Massachusetts how he proposes to get it amended? Why, sir, by abrogating the whole of it-blotting it out! What do you surrender by that? You surrender your right of fishing. You surrender the right of navigation of the St. Lawrence. You surrender the right of carrying vessels down the Welland Canal. You isolate the Lakes. You surrender all that upon the suggestion that after you have done this you can institute some measure of new diplomacy and inaugurate some new treaty by which everything that is valuable to us may be secured. It is a delusive idea. If you abrogate the treaty it will be looked upon in Canada, it will be looked upon by Great Britain, and it will be looked upon in this country by some certainly, as a measure of retaliation springing out of resentment, which I grant you is just, for some wrongs we have suffered at the hands of these colonies." I Hale held up to scorn an argument in favour of the abrogation of the treaty that had been advanced in the Senate, that such a proceeding would reduce Canada to bankruptcy and pauperism. But he saw and admitted that abrogation was then a foregone conclusion with the Senate.

Sumner assured the Senate that had the treaty related only to the fisheries he would

1 Congressional Globe, January 11, 1865. 
not have been willing to touch it. He quoted figures to show that the St. Lawrence navigation was of little value-that in the first six years of the treaty only fifty-nine American vessels, with an aggregate cargo of 17,950 tons, had used the St. Lawrence waterways, and asserted that the United States revenue had suffered from the excess of imports over exports in the Canadian trade. The arrangement with Canada constituted an inequality which in ordinary times might have escaped observation, but which was too apparent " in the blaze of present responsibility," due to the war. "Something," continued Sumner, "has been said about accompanying the present notice to Great Britain with instructions to negotiate a new treaty. This is entirely unnecessary. A new treaty may not be advisable. It is possible that the whole matter may be settled by Congress under the general laws." 1

Sherman of Ohio, Chairman of the Senate Committee on Finance, intimated that he should vote for the resolution with great pleasure. "We open to them a market of thirty millions: they give us a market of three millions," was one of Collamer of Vermont's arguments for abrogation. "The sentiment of our state," said Foot, also of Vermont, "was against the treaty long before the war. Our state legislature has passed a resolution urging its abrogation." "The

1 Congressional Globe, January 11, 1865. 
Canadians make discriminating duties against us," continued Collamer, after this interjection from his colleague from Vermont. "When in consequence of their increased indebtedness for their internal improvements, Canadians were obliged to raise their duties, and laid them upon British as well as all other goods, and they were asked by Lord John Russell, 'Why is it that you have increased the duties on British goods?' they replied, 'We were obliged to do so; but at the same time we changed them, you know, from specific to ad valorem duties, and gave the advantage by that to Great Britain.' 'Oh well,' Lord Russell replied, 'we are satisfied. You have given us a satisfactory answer."

From Howe of Wisconsin came a plea for the treaty almost as strong as that of Hale. $\mathrm{He}$ admitted, as Hale had done, that the Canadians had given offence during the war. "But," he asked, "who stands here pleading for favours to the Canadian people? I am asking for favour for our own people. It is in the name of American interests that I ask that the treaty shall not be struck down. We need not lose our senses because the Canadians have lost possession of their temper. I have heard, I believe, not of men but of children being mad enough to bite their own noses off. I never saw the duty enforced by statesmen until this debate sprang up." 1

The next day, January 12, the debate was

${ }^{1}$ Congressional Globe, January 11, 1865. 
resumed by Zack Chandler of Michigan, famous for his intemperate advice to Lincoln at the Mason and Slidell crisis at Washington. Taylor was anxious to see the resolution carried without a single dissenting voice. "I was opposed," he said, "to the treaty when it was adopted, and I have been opposed ever since. I hope that at the very first hour, when we can by the terms of the treaty give notice of its abrogation to Great Britain, notice will be given." Conness of California, one of the first Irish-Americans to be of the Senate, urged abrogation "because we have been cheated in this arrangement." "If we feel," he said, referring to the ill-humour against England, "offence at any party in Great Britain -it is not against the enlightened and liberal friends we have there, whom we appreciate, and who have accepted and performed the rule of justice towards us; but it is against the governing power in Great Britain and the provinces-it is against the power that has done acts of injustice towards us."

Wilson, Sumner's colleague from Massachusetts, who had always been in favour of the treaty, admitted that it needed modification, and informed the Senate that this was the opinion of the people of Massachusetts. To secure a more favourable treaty, he proposed an amendment, which was afterwards ruled out of order, providing for the appointment of commissioners by the President, and setting forth in its preamble that it was 
desirable that the existing friendly relations should continue between the United States and the British North American Provinces, and that "commercial intercourse should hereafter be carried on between them upon true principles of reciprocity."

The last word in the Senate debate was from Hendricks of Indiana, who was VicePresident from 1885 to 1889 . His speech ranks with that of Hale in defence of the treaty. Hendricks was certain that no senator desired any embarrassments between the United States and Great Britain. "I have heard of men," he said, "who are very valiant, who say we can fight the world, defy Britain, defy France. But suppose we can. Is it wisdom to do it? I do not suppose that any action we may take on this question will bring about trouble; but it does not increase the securities of peace. No senator claims that. It opens questions up again that for the time being were settled. There are no commercial troubles that can come up between us and Canada while this treaty remains." "There is another feature about this treaty that I like," continued Hendricks, who, as Democratic Vice-Presidential candidate, made the campaign with Cleveland against the Morrill tariff in 1884 : "It provides to a considerable extent for free trade between us and a neighbouring province. I like that. I believe that the civilisation of the world will come up to that standard which will secure free trade the world over. Let 
trade regulate itself. Let each nation support its own revenue from its own people. 'The fact that Canada is a province lying just alongside our territory is a reason why I like free trade between that province and our own country."

The friends of the treaty - those who regarded it as did Hale, Howe, Wilson, and Hendricks-made one last effort. An attempt was made to refer the resolution of which Sumner was in charge to the Committee on Commerce. It failed, as the friends of the treaty had foreseen. By thirty-three yeas to eight nays-with eight senators absentSumner's resolution was adopted. ${ }^{1}$ The House of Representatives agreed to the joint resolution as amended by the Senate. Adams, United States Minister in London, informed Lord John Russell, Secretary for Foreign Affairs in the Palmerston administration of 1859-65, on March 17, 1865, that he was charged to notify the British Government that it was considered no longer for the interest of the United States to continue the Elgin-Marcy Treaty ; ${ }^{2}$ and on March 17, 1866, American fisheries rights reverted to the status of 1818 ; it was again possible for the legislature of New Brunswick to impose export duties on logs from Maine, which were shipped from St. John, and for the legislature of the United

1 Congressional Globe, January 12, 13, 1865.

${ }^{2}$ Cf. Hertzlett's Treaties and Conventions, xii. pp. 938, 939 ; Blaine, Twenty Years of Congress, ii. p. 621. 


\section{PROTECTION IN CANADA сн.}

Provinces to close the canals to American shipping; and from March 17, 1866, also, natural products from British North America, which since 1854 had been admitted into the United States duty free, came under the operation of the tariff which was enacted at Washington during the year. ${ }^{1}$

1 The duties were: wheat, 20 cents a bushel; barley, 15 cents a bushel ; live stock, 20 per cent ad valorem; fresh, smoked, and salted meats, 45 per cent ; timber and lumber of all kinds, 20 per cent ; seeds, 30 per cent; vegetables, 10 per cent; fruits, dried and undried, 10 per cent ; fish of all kinds, $\frac{1}{2}$ cent a pound ; products of fish, 20 to 30 per cent; poultry, 35 per cent; furs and skins, 10 per cent ; stone, crude and unwrought, 20 per cent ; slate, 40 per cent; butter and cheese, 4 cents a pound ; tallow, 1 cent a pound; ores of metals of all kinds, 20 per cent ; coal, $\$ 1.25$ a ton ; plants, shrubs, and trees, 30 per cent; wool, 30 per cent; barks, 10 to 20 per cent; grindstones, 10 per cent; flax, $\$ 15$ a ton; and rags, 10 per cent. 


\section{CHAPTER VI}

RECIPROCITY : OVERTURES BY CANADA SINCE 1866

IT would be well that the people of Canada should bear in mind that Canada is by the necessity of its position an integral part of this continent of North America, and that we have to all intents and purposes no other neighbour than the United States.

-Sir Richard Cartwright.

Canada had been aware since 1861, when the New York Legislature took action, that the reciprocity treaty would have either to be mended or ended. From 1864 Canadians must have been conscious that the United States would abrogate the treaty. Its denunciation in 1865 could not have come as a surprise to any of the British North American Provinces; but from then until 1899 there was always hope in Canada that another reciprocity treaty might be arranged. In these thirty years there was always some more or less intermittent movement to that end; and hope as to its ultimate success was strongest among the farmers of Ontario 
and Quebec, and among the fishermen of the Maritime Provinces-among those who suffered most loss and inconvenience from the abrogation of the treaty, but who were not responsible for any of the causes that brought it to an end.

Almost invariably it is the innocent who suffer in tariff wars. It has been so in the war in which Canada has been engaged since 1904 with Germany. It was eminently so in the tariff war which Cayley and Galt began to wage with the United States after these Canadian Ministers of Finance committed themselves to the National Policy of the Association for Promoting Canadian Industries. The Maritime Provinces had absolutely no responsibility for any of the tariff mancurres which aroused so much hostility to the ElginMarcy Treaty between 1858 and 1860 in New York State and New England. The increases in the duties on manufactures; the change from specific to ad valorem duties; and the differential tolls on the canals were all by virtue of enactments for which the Government and Parliament of the United Provinces were solely responsible. Two of these measures-the increase in the duties and the change to ad valorem duties-penalised the farmers of Ontario and Quebec for the benefit of the manufacturers of these two provinces. Thus these agricultural interests were hit by the duties imposed by the Canadian Parliament, and were still more 
injured by the retaliation which these duties provoked from the United States; for in 1866 Canada marketed twenty-five million dollars' worth of farm products in the United States as compared with three-and-a-half millions exported to Great Britain, ${ }^{1}$ and the farmers of Ontario and Quebec, especially those of Ontario, were never more prosperous between the union of the provinces in 1841 and the end of the nineteenth century, than in the eleven years in which they had free access to their adjacent and natural market in the United States.

Three times, between 1866 and 1874, Canadians were negotiating at Washington for a renewal of the arrangement of 1854-66. ${ }^{2}$ The two earlier efforts to this end, when it was sought to re-establish reciprocity by concurrent legislation, ${ }^{3}$ were quite futile; and it was not until 1874 that the efforts resulted in a draft treaty. In the earlier efforts the United States Government was so far interested as to appoint Mr. Josephus N. Larned of Buffalo, an Ontarian by birth, ${ }^{4}$ to make an exhaustive report on the history and statistics of the trade relations between the two countries. Mr. Larned's report, like that of Hatch of 1860, was dated from Buffalo. It

1 Cf. Charlton, The Forgotten High Commission, Globe, June 23, 1906.

2 Cf. Charlton, Trade Relations, Globe, June 2, 1906.

3 Cf. Haynes, The Reciprocity Treaty with Canada of 1854, p. 30 .

4 Cf. Who's Who in America, 1906-7, p. 1045. 


\section{PROTECTION IN CANADA сн.}

was submitted to Congress in 1871. It is the most exhaustive United States document in print regarding the Elgin-Marcy Treaty. From beginning to end it is a justification of the action taken by Congress in 1865 in bringing about its abrogation. "It was simply impossible," Mr. Larned wrote, "that an arrangement of incomplete free trade so nonreciprocal, so one-sided in its operation, and so provokingly the result, as was the treaty of 1854, of a sharply-forced bargain on the fisheries question, could be allowed to continue beyond the term for which it was contracted. It was justly abrogated ${ }^{1}$ in 1866 by the act of the United States Government, with the very general satisfaction of public opinion in the country; and yet there are probably few among those who opposed the continuation of the reciprocity treaty of 1854 , and who oppose its renewal in any similar form, who are not fully convinced that an intimate unrestricted commerce with the neighbouring communities would be of great

1 A Convention composed of Boards of Trade and Chambers of Commerce of the United States and British North American Provinces met at Detroit, July 11-14, 1865, by invitation of the local Board of Trade, to protest against the abrupt termination of the reciprocity treaty. They came "to substantial unanimity, and united in urging upon the Government at Washington the great importance of immediately opening negotiations with the British Government for a new arrangement, at the least as liberal on both sides as the one about to expire had been, and as much broader as should appear practicable. Their action was approved by every Board of Trade and Commerce in the country taking any interest in the matter; it was disapproved, so far as we have ever heard, by none."-Editorial article by J. C. Bates of Boston, cited by Haynes, The Reciprocity Treaty with Canada of 1854, p. 29. 
benefit to this country, and certainly would be an incalculable stimulant to the growth of those communities."

"The question," continued Mr. Larned, in taking up the future trade relations of the United States and Canada, in this report of 1871, "is one of adjustments. Free trade, or any approach to naturalness of commercial intercourse between these quasi-foreign neighbours and ourselves, is impossible unless the outside conditions and commercial relations of the two countries can be brought into harmony with each other. If the exterior relations of the two countries were so adjusted to one another as not to interfere on either side with a natural circulation of free trade between themselves, probably not one intelligent voice would be raised against the abolition of all customs-houses on our northern frontier." 1

Mr. Larned conceded that reciprocity was desired in the United States as well as in Canada. But he reprinted in his report all the correspondence that in 1859 and 1860 had passed between Galt and the Colonial Office in London concerning the avowedly protectionist tariff of the United Provinces of 1859 . These letters, and other colonial British correspondence, were quoted to prove that while Canada in 1870 was protecting its manufactures by its tariff legislation, it was also seeking to throw what

1 Larned, Report on State of Trade with British North American Provinces, Executive Documents, 1871, No. 94, pp. 5, 6. 


\section{PROTECTION IN CANADA cr.}

trade in manufactures it could not itself supply to Great Britain by the ad valorem system, which was prejudicial to the United States manufacturers in their competition with manufacturers in England. Emphasis was also laid on the fact that had been brought out in the discussions of the Elgin-Marcy Treaty in Congress between 1859 and 1864 , that while the United States was desirous of reciprocity with Canada, they had, to use an Americanism, " no use" for it unless manufactures were included in the duty-free list. " We want," Mr. Larned wrote, in summing up his conclusions on this aspect of reciprocity, "such an adjustment of trade that the provinces shall not sell what they have to sell in the United States, and buy what they have to buy in Great Britain." 1 Mr. Larned was not sanguine in 1871 that reciprocity on the lines he suggested could be secured, because Canada could not discriminate in favour of the United States and against Great Britain. ${ }^{2}$

Mr. Larned's report and the general acceptance of its conclusions as to the impossibility of a treaty that should give any advantage to American manufacturers, was not without its influence in Canada, especially when the Liberal Government of 1874-78 took up the question of reciprocity, and pushed with much vigour for a new treaty. In the first tariff that was enacted after Confederation-the tariff of 
1870, for which the Macdonald Government was responsible, and which was the last tariff enacted by a Conservative Government before the Conservative party committed itself to high protection-there was an offer of reciprocity to the Unitd States, similar in scope and character to the offer that was embodied in the tariff of the United Provinces in $1846 .{ }^{1}$ But the Government at Washington was not in the least drawn to another reciprocity treaty to be applicable only to natural products; and in 1874, within a short time after the Mackenzie Government came into power at Ottawa, Brown of Toronto, who was now of the Dominion Senate, was appointed a commissioner, and was associated with Thornton, the British Minister at Washington, in the negotiations which resulted in the draft treaty of 1874 .

The first movement at Ottawa towards securing a new treaty in 1874 was on February 23. An order in council was then passed in which the belief was affirmed that there was at that time a most favourable opportunity for a renewal of negotiations at Washington. Dufferin, the Goveruor-General, in forwarding the order in council to London, assured Carnarvon, the Colonial Secretary, that the action of Mackenzie and his colleagues of the Ottawa administration would be generally approved throughout the Dominion. "They assure me," he added, "that it will meet with

${ }^{1}$ Cf. Dominion Statutes, 31 Vict. c. 44. 
$\mathrm{CH}$.

the approbation of Parliament." 1 The British Government gave its sanction to the negotiations as promptly as it had done in 1848 , when Herries so cordially endorsed in the House of Commons the movement that the United Provinces and New Brunswick were then making for the first reciprocity treaty. Brown's commission passed the Great Seal on March 21; and early in April the Canadian Commissioner, accompanied by A. J. Smith, Minister of Marine and Fisheries in the Mackenzie administration, was at Washington, and at work with the British Minister on the draft treaty.

In support of the case for Canada a long memorandum was submitted to Fish, Secretary of State at Washington, which covered the history of trade relations between Canada and the United States for fifty years, and in which it was urged that both countries would derive advantages from closer trade relations than those then existing. Statistics were quoted to show that from 1854 to 1866 -the period in which there was freedom of trade in natural products - the balance of trade in favour of the United States was over twenty million dollars. "No doubt," writes Mr. Charlton, " as good a showing was made in the interest of the Canadian contention as the circumstances would admit of." ${ }_{2}$

The system.which exists to-day, under which freight from the American side of the boundary

1 Cf. Charlton, Trade Relations, Globe, June 2, 1906. 
line en route for another point in the United States is carried in bond-as, for instance, that which is carried over the Grand Trunk from Windsor on the Detroit river to railway points on the American side of the Niagara river, or that for Montreal or Toronto which is carried from Portland, Maine, in bond---was first put into service in 1846. Canadian railways derive much advantage from the system. So do Canadian importers and shippers; but from the difference in population of the two countries, and from the greater industrial and commercial activity on the southern side of the border, the bonding system is of far greater importance to the United States, for under it much eastern and western American trade passes through Ontario. Stress was laid on the value of the bonding system to the United States in the Thornton-Brown memorandum of 1874. 'The privileges accorded to American fishermen under the Elgin-Marcy Treaty were also recalled. Regret was expressed at the abrogation of the treaty, and it was contended that the United States was by no means the least sufferer from the ending of the partial system of free trade that came in 1866 . The people of Canada, the memorandum further declared, were not ignorant of the fact that a market near at hand was better than a market at a distance, and good as their present markets were, they would be glad to have the old market in addition.

Galt's tariff of 1859 had given some impetus 
to manufacturing in Canada. Even before the tariff of 1859 several industries had reached the factory stage. As early as 1848 the pioneer cotton mill in British North America was established at Thorold, near St. Catherine's, Ontario.' Another cotton manufacturing company was organised at Collingwood, Ontario, in $1859 ;{ }^{2}$ and between 1861 and 1864, William Parks, who had come from the north of Ireland, had equipped a factory at St. John, New Brunswick, with spindles and looms. ${ }^{3}$ About 1846 a woollen mill was established at Coburg, Ontario. ${ }^{4}$ From 1822 there had been a number of small woollen mills in Nova Scotia, one of which was known beyond the Maritime Provinces for its Halifax tweeds. ${ }^{5}$ There was a soap factory in Montreal as early as 1845 . It was the first Canadian industry in connection with which the cry was raised that Canada was used as a slaughter market for British and American products - the first industry to which tariff protection was granted to safeguard it from what in later years has been known in tariff discussions at Ottawa as dumping. ${ }^{6}$ Papermaking was begun in Ontario in 1846. In 1860 sewing machines were being made at a

1 Cf. Globe, June 10, 1848.

2 Cf. Statutes of Canada, 22 Vict. c. 110.

3 Cf. Duncan Campbell, Nova Scotia in its Historical, Mercantile, and Industrial Relations, p. 509.

${ }^{4}$ Cf. Sullivan, Lecture, Mechanics' Institute, Hamilton, 1847, p. 25 ; Statutes of Canada, 9 Vict. c. 94 ; House of Commons Debates, March 9, 1899.

${ }^{5}$ Cf. Gresner, The Industrial Resources of Nova Scotia, p. 204 ; Canadian Journal of Fabrics, 1885.

${ }^{6}$ Cf. Globe, July 12, 1858. 
factory in Montreal. ${ }^{1}$ 'There was a mill at Toronto in 1860 for rolling railway iron. The first mill for rolling merchant iron was established at Hamilton, Ontario, in 1864; and by 1870 pig-iron was being made at Radnor, Quebec; at Londonderry, Nova Scotia; and at Woodstock, New Brunswick. ${ }^{2}$

None of these industries was on a large scale in 1874, when the Dominion Government was making the most serious effort to secure a new treaty that has been made by any Government at Ottawa since the Elgin-Marcy Treaty came to an end. The cotton industry was perhaps the best developed; but six years after the rejection of the draft reciprocity treaty by the Senate at Washington, the call of Canadian cotton mills for cotton from the United States was only a little under twenty thousand bales, as compared with a hundred and forty thousand bales, the quantity taken in 1906 by the three companies, with headquarters in Montreal, which control the manufacture and marketing of cotton goods in the Dominion. ${ }^{3}$

The output of pig-iron in 1874 , when the draft treaty was in negotiation at Washington, is difficult to ascertain. Ten years later, when the Government first began to pay bounties

1 Cf. Buchanan, Britain the Country versus Britain the Empire, p. 158.

2 Cf. Bartlett, Iron, Steel, and Coal in Canada, pp. 30-35.

3 Cf. Supply and Distribution of Cotton, Bureau of the Census, Washington, 1906, p. 8 ; Herald, Montreal, January 1, 1905; Calladian Trade Index, 1901, p. 16. 
on pig-iron, the output was only 27,960 tons ; ${ }^{1}$ and between 1874 and 1883 , when the iron bounty legislation was enacted, another ironmaking company had been organised, and had installed its plant at Drummondsville, Quebec. In this period, however, the plant at Woodstock, New Brunswick, had been abandoned.

An estimate may thus be made of the state of manufacturing in 1874, when the Mackenzie Government was intent on a new reciprocity treaty. The Ottawa Government had these conditions in mind when, in the memorandum of April 28, it expressed its desire for a freer exchange of commodities, "so long as it was not seriously prejudicial to Canadian industrial interests." It was in the memorandum containing this saving clause that the Canadian Government suggested that the free list in the new treaty should embrace animals and their products; products of the farm; products of the mines ; products of the water ; dye-stuffs ; agricultural implements to be defined; bark; bricks; ochres; hay; lime ; malt ; manufactures of iron or steel ; manufactures of iron or steel and wood jointly; manufactures of wood; mineral or other oils; plaster, raw or calcined; salt; straw ; stone, wrought or unwrought.

The British Government approved the memorandum on May 22; and after many conferences at Washington between Thornton and Brown, representing Great Britain and Canada, and Hamilton Fish, Secretary of State

1 Cf. Auditor-General's Report, 1885. 
in Grant's second administration, the draft treaty was agreed upon, and transmitted to Derby, Secretary of State for Foreign Affairs in the Beaconsfield administration of 1874-81. The draft was promptly approved by the British Government; and after July 3, when Thornton was notified of the Government's approval, the fate of the treaty rested with the Senate of the United States.

The free list which had been approved by the British Government, the Canadian Government, and the United States Secretary of State, showed little trace of anxiety about the Canadian industrial interests, to which reference had been made in the British ThorntonBrown memorandum of April 28. It is obvious that both Mackenzie and Brown fully realised the weakness of the old treaty from an American point of view; and that in working on the draft of the treaty of 1874 they had kept in mind the objections in Congress at Washington between 1859 and 1864, that the Elgin-Marcy Treaty offered no advantages to American manufacturers.

Mackenzie and Brown were free traders. Their free trade principles came fully into play in drafting the new reciprocity treaty, as they did again two years later, when Macdonald and the Conservative Opposition at Ottawa committed themselves to the National Policy. From 1876 to 1878 Mackenzie and Brown faced the risk of defeat at the general election in 1878, and in the end sustained 
CH.

defeat, rather than abandon their political principles.

These men were of the old school of Canadian Liberalism. They were of the school that had been enormously influenced by Liberalism in England. ${ }^{1}$ The Liberalism of Brown and Mackenzie survived in Canada until 1897. It reached its zenith at the Ottawa Convention of 1893, which adopted a programme which embodied all the political principles that Mackenzie and Brown had professed. Outside of the Cabinet, and beyond the walls of the Parliament House at Ottawa, this school of Liberalism still survives. But as a Parliamentary force it came to an end in 1897 , and it may fitly be said that when Mackenzie and Brown agreed to the free list in the draft reciprocity treaty of 1874 , they made the last positive effort of any Liberal leaders in Canada on behalf of the political principles on which the Liberal party was founded.

'The draft treaty provided that the relations which it was to establish-relations affecting the canals and the St. Lawrence navigation, and the registration of ships, as well as international trade-were to continue for twentyone years, and to be determinable only on three years' notice. But the Senate, with which lies the fate of all treaties made by administrations at Washington, refused to ratify it; and to-day about the only value attaching to the draft treaty lies in the schedules of the free

1 Cf. Long, Canadian Politics, pp. 57, 58. 
list, which show how far the Government of Canada, with the approval of a Conservative administration in Downing Street, was prepared to go in 1874 in meeting the objections to the reciprocity treaty of 1854-66.

Three schedules embodied the free list. Schedule A consisted of natural products, and contained a list of articles, sixty in number. Included in the list were animals of all kinds; bread-stuffs of all kinds; cheese ; butter ; eggs; fish; flour and meals of all kinds; ores of all kinds; petroleum, crude and refined; poultry; timber and lumber of all kinds; vegetables; and wool. Schedule B contained a list of agricultural implements, forty in number, which covered the entire list of agricultural implements and tools, from a thrashing machine down. Schedule $\mathrm{C}$ contained a list of manufactures, thirty-seven in number, included in which were boots and shoes; a list of cottons; furniture; carriages ; iron; manufactures of leather ; manufactures of wood ; mill and steamboat engines; locomotives; cars; satinets; tweeds; steel ; paper; and printing presses and material.

Without going so far as commercial union, as it was advocated by Isaac Buchanan between 1859 and 1862 and again in the early eighties in Montreal and Toronto, ${ }^{1}$ it is not conceivable that the Dominion could have offered more to the United States than was offered by the Mackenzie Government. But even after the

1 Cf. Morgan, Dominion Annual Review, 1880, 1881. 


\section{PROTECTION IN CANADA сн.}

rebuff from the Senate at Washington in 1874 , the desire for reciprocity continued until the abortive Joint High Commission of 1898-99, and until the Liberal Governments in power at Ottawa between 1896 and 1907 gave themselves up as regards the tariff to the politics of business, adopted the National Policy of the Conservatives, and extended the application of this policy in new and unlooked-for directions.

The desire for reciprocity has survived with the fishermen and lumbermen of the Maritime Provinces, and with the farmers and lumbermen of Ontario and Quebec. But since 1878 there has never been any sincerity towards reciprocity with politicians in office at Ottawa - whether Conservative or Liberal. The Conservatives, when they enacted their first National Policy tariff in 1879 , included in it a clause similar to that in the tariffs of 1846 and $1870 .^{1}$ Commissioners, appointed by both Conservative and Liberal Governments, have been at Washington in the interest of reciprocity on two occasions since 1879. They were there in 1892, and again in 1898-99; but in each instance the negotiations by these Canadian commissioners were perfunctory fulfilments of election campaign promises - campaign pledges which in each instance had become meaningless before the commissioners left Ottawa for Washington. The negotiations could not be otherwise than perfunctory, because in 1892 and in 1898-99 the Governments at Ottawa

${ }^{3}$ Cf. Morgan, Dominion Annual Review, 1884, p. 89. 
knew that the United States would consider no arrangement for reciprocal trade which was confined to natural products; and both the Macdonald Government in 1892, and the Laurier Government in 1898-99, were too deeply committed to the National Policy to be able to make any tariff concessions to United States manufacturers.

During the Parliament of 1887-91 the Liberal opposition, led by Sir Richard Cartwright, pressed the question of reciprocity on the House of Commons and the country. The attack along these lines was begun in 1888 , when Sir R. Cartwright proposed absolute free trade, both in manufactured goods and natural products. ${ }^{1}$ In the session of 1889 he moved two distinct resolutions in favour of reciprocity. One of these was for an address to the Queen, praying Her Majesty to empower the Canadian Government " to enter, by an agent or representative of Canada, into direct communication with any foreign state for the purpose of negotiating commercial arrangements tending to the advantage of Canada," and sixty-five Liberal members of the House of Commons voted for this resolution. ${ }^{2}$ Sir Richard Cartwright's second resolution immediately followed Mr. Foster's budget speech. It called for a reduction of duties in the tariff, and urged that the negotiations which the Macdonald Government were intending to open at

1 Cf. House of Commons Debates, March 14, 1888.

2 Ibid. February 18, 1889. 


\section{PROTECTION IN CANADA сн.}

Washington should be "conducted upon the basis of the most extended freedom of trade between Canada and the United States, in manufactured as well as natural products." 1

On the eve of the general election of 1891 , and after Parliament had been dissolved, the Government announced that its commissioners were going to Washington to negotiate "along lines of limited reciprocity." Sir C. Tupper, who hurried from London, where he was Canadian High Commissioner, to take part in the campaign, gave the electors to understand that the Canadian commissioners were going to Washington on the initiative of the United States Government; ${ }^{2}$ and the Dominion Government appealed for a large majority at the election, so that the Government at Washington might see that the people of the Dominion were behind the Government in this new movement for reciprocal trade. The response of the Dominion was a majority of thirty-one. An episode of this election was Mr. Blake's farewell address to his constituents in the West Durham Riding of Ontario, in which the late Liberal leader explained why he could not support Sir W. Laurier and Sir R. Cartwright and other of his colleagues, in the Parliament of 1887-91, in their movement for unrestricted reciprocity with the United States. ${ }^{3}$

1 Cf. House of Commons Debates, March 5, 1889.

2 Cf. Speech by Sir Louis Davies, of Prince Edward Island, Ottawa Convention, 1893, Official Report, p. 80.

3 Cf. J. Castell Hopkins, Chronology of Canadian History from Confederation to 1900 , p. xx. 
Macdonald died in June 1891, and was succeeded as Premier by Abbott, who had been Government leader in the Senate. The Government moved with leisure in fulfilling the election pledge of 1891 as to reciprocity. It was February 1892 before there was any news from Sir Mackenzie Bowell, Mr. Foster, and Sir John Thompson, the Canadian commissioners at Washington. It then came in the form of an official report, signed by the commissioners, and endorsed by Lord Pauncefote, the British Minister, to the effect that Blaine, Secretary of State, "refuses to negotiate except on a basis of free trade in natural and manufactured products, and a combined tariff against all other countries." 1 This was the official message to the people of the Dominion. It was ten months later before the result of the negotiations was officially announced to the people of the United States.

"During the past year," wrote President Harrison, in his annual message to Congress, December 6, 1892, " a suggestion was received through the British Minister that the Canadian Government would like to confer as to the possibility of enlarging, upon terms of mutual advantage, the commercial exchanges of Canada and the United States; and a conference was held at Washington, with Mr. Blaine acting for this Government, and the British Minister at this capital and three members of the Dominion Cabinet, acting as commissioners on

1 Chronology of Canadian History, p. xxi. 
the part of Great Britain. The conference developed the fact that the Canadian Government was only prepared to offer to the United States, in exchange for the concessions asked, the admission of natural products. The statement was frankly made that favoured rates could not be given to the United States as against the Mother-country. This admission, which was foreseen, necessarily terminated the conference. The benefits of an exchange of natural products would be almost wholly with the people of Canada."

So long as the Liberals were in opposition they were profuse in their promises to the Canadian people that were they returned to power they would assuredly succeed where the Mackenzie and the Abbott Governments had failed. Half a day was devoted to reciprocity at the Ottawa Convention of 1893 ; and from the Committee on Resolutions, of which Mr. Fielding was chairman, came the reciprocity plank, which, with complete unanimity and much enthusiasm, was made part of the famous Ottawa platform - the platform on which Sir Wilfrid Laurier and the Liberals in every province of the Dominion went into the general election of 1896 . The reciprocity resolutions thus accepted by representative Liberals from every province except'j British Columbia, in convention assembled, on June 21, 1893, were as follows:-

1 Richardson, Messages and Papers of the Presidents, ix. pp. $313,314$. 
That having regard to the prosperity of Canada and the United States as adjoining countries, with many mutual interests, it is desirable that there should be the most friendly relations and broad and liberal trade intercourse between them;

That the interests alike of the Dominion and of the Empire would be materially advanced by the establishing of such relations;

That the period of the old reciprocity treaty was one of marked prosperity to the British North American colonies ;

That the pretext under which the Government appealed to the country in 1891 respecting negotiations for a treaty with the United States was misleading and dishonest, and intended to deceive the electorate;

That no sincere effort has been made by them to obtain a treaty, but that, on the contrary, it is manifest that the present Government, controlled as they are by monopolies and combines, are not desirous of securing such a treaty;

That the first step towards obtaining the end in view, is to place a party in power who are sincerely desirous of promoting a treaty on terms honourable to both countries;

That a fair and liberal reciprocity treaty would develop the great natural resources of Canada; would enormously increase the trade and commerce between the two countries; would tend to encourage friendly relations between the two peoples; would remove many causes which in the past have provoked irritation and trouble to the Governments of both countries; and would promote those kindly relations between the Empire and the Republic which afford the best guarantee of peace and prosperity ;

That the Liberal party is prepared to enter into negotiations with a view to obtaining such a treaty, including a well-considered list of manufactured articles; and we are satisfied that any treaty so arranged will 
receive the assent of Her Majesty's Government, without whose approval no treaty can be made. ${ }^{1}$

The Maritime Provinces, ever since 1848, had been in favour of reciprocity; and accordingly the motion for the adoption of the reciprocity resolutions was entrusted to a member of the House of Commons from "down by the sea"-Sir L. Davies of Prince Edward Island, who was Minister of Marine and Fisheries in the first Laurier Government until his appointment to the bench of the Supreme Court at Ottawa. " "South of you," said Sir L. Davies, warming to his subject, "lies the greatest republic the world has ever seen, people who are sprung from the same stock as yourselves, worshipping before the same altars, speaking the same language, discussing the same questions, and looking forward with almost the same hopes. Can you doubt that the greatest good that any man can confer upon Canada will be to cultivate such friendly relations with that people that war between Great Britain-the Mother-land-and the neighbouring republic would become an impossibility? The resolution expresses the idea that the period of the reciprocity treaty, extending from 1854 to 1866 , was one of marked prosperity. I cannot speak with the same assurance in regard to other parts of the Dominion as I can in regard to that part from which I come; but I say this, that since the Maritime Provinces were peopled, there never was a

1 Report, Ottawa Convention, 1893, p. 81. 
decade when prosperity was so marked among all classes, when land rose in value so quickly, when the wharves were so lined with shipping, when the workmen had such steady employment, when the farmers had as good a market, as between 1854 and 1866, when we had reciprocal trade with the United States of America. We look back with longing eyes to that period of free trade with our neighbours, and we look forward with hope that the Liberal party, coming to their own again, shall bring back the prosperity of that period to us."

Earlier in this survey of the attitude of the politicians at Ottawa towards reciprocity since 1878, it has been suggested that it lacked sincerity. This was the conviction of the Liberals while they were in opposition; and expression was given to this conviction, both in the resolutions of the Ottawa Convention and the speeches in support of them. "This resolution," said Sir L. Davies, "affirms that the Government have been guilty of misleading and dishonest statements, with the deliberate object of deceiving the electorate. They went before you the last time with an official document in their hands, declaring that they had been invited by the United States Government to discuss reciprocity; and thousands of people said, "The Government have now been asked to go there to discuss a treaty; we will give them a chance to do it.' They deceived the people. They made dishonest and misleading statements, and they got thousands of 
votes by it. But when the representative of Canada went to the United States, in pursuance of a resolution which was passed by Parliament, the first thing he had to do, to the humiliation of this land - Sir Charles Tupper had to go in and on bended knees declare to Mr. Blaine, 'I am obliged to say that the statements Sir John Macdonald and I myself made to the effect that the invitation to discuss reciprocity had emanated from the United States were not correct.' Such a spectacle as this, so humiliating to Canada, could never occur under a Liberal Government. They made no sincere effort to obtain reciprocity."

Other international questions ${ }^{2}$ besides reciprocity were before the abortive Joint High Commission of 1898-99, on which Sir Wilfrid Laurier, Sir Richard Cartwright, Sir Louis Davies, and Mr. John Charlton were the Canadian representatives. The LaurierGovernment was undoubtedly sincere in its desire for a settlement of the questions which did not affect trade. On the trade question its attitude was not one whit more sincere than that of the Macdonald and Abbott Governments in 1891-92. It was well aware of the position of the United States Government as to reciprocity, for the American position has undergone no change since 1859. The United

1 Report, Ottawa Convention, p. 79.

2 Atlantic fisheries, protection of seals on the Pacific coast, war vessels on the Great Lakes, the Alaska boundary, fishing in the Great Lakes, and the transportation of merchandise in bond. 
States Government has never varied from the position that if Canada desires reciprocity she must be willing to make concessions to American manufacturers.

While the position of the Washington Government has thus remained unchanged for half a century, the position of the Government at Ottawa has changed enormously since 1879. It is not Great Britain or the reluctance of Canada to make tariff concessions to the United States that would be prejudicial to British manufacturers that is nowadays the chief obstacle to reciprocity, as it might have been in the days when Galt and Howland were Ministers of Finance, and were both eager for freer trade relations with the United States. It is the strongly organised protected manufacturers of the Dominion who have urged each successive Government further and further from the point at which concessions could have been made to the United States.

The process of forcing the Government away from the point where the Mackenzie administration stood at the time of the Thornton-Brown draft treaty of 1874 has been continuous since 1879 , and has met with no real resistance from either Conservative or Liberal administrations at Ottawa. Each new tariff since 1879-every renewal of the bounty legislation which was first enacted in 1883 ; every concession to the "made in Canada" sentiment, which has been systematically worked up by the Canadian Manu- 
facturers' Association since 1900 ; every new concession to protectionist sentiment that has been embodied in the tariff laws, in the railway code of the Dominion, or in the regulations of the post office for the interchange of printed matter with the United States, has increased the distance from the point at which the Mackenzie Government stood when the free list schedules of the draft treaty of 1874 were determined upon by the British commissioners at Washington, and Hamilton Fish, the United States Secretary of State.

Nor can the Ottawa Government begin to return to the position of 1874 so long as politics continue as they are at Ottawa. The constituencies can neither stay the protectionist movement in Canada nor change the attitude of the Dominion Government towards reciprocity. The degeneration of government by party, due almost exclusively to the working of the protectionist system-the degeneration which has been so rapid and so manifest since 1896-has left the constituencies helpless, and has made the politics of business easily dominant in Dominion government. No signs of a change are yet in sight. In a country so thinly peopled as Canada, a country with such widely extended boundaries, it seems impracticable to organise a third political party.

Great obstacles confront any such movement. The Government controls the machinery of the Liberal party and the Liberal organs in the press. It controls all Dominion patronage ; 
and through its close connection with some of the Provincial Governments-for instance with that of Nova Scotia-it indirectly controls much of the patronage of the Provincial Governments. It controls all Dominion expenditures. It is careful that contracts, like offices, go to none but its partisans. Through the caucus it can suppress any tendency towards independence among the rank and file of its supporters in the House of Commons, and penalise any member elected as a Liberal who dares to assert his independence.

At present the organisation of a third party that could exercise a check on the politics of business seems impracticable. No help in effecting a change is to be had from the Conservative Opposition. Its demoralisation is complete; for never since Confederation was there an Opposition less formidable, of less constitutional value to the Dominion, less regarded in the constituencies, with less moral force behind it, or less trusted by the people than the Conservative Opposition which, since the defeat of the Tupper Government in 1896, has raised no standard in Parliament or in the constituencies, except the opportunist cry for more protection. The Opposition is now as useless as the Senate. It occasionally throws a searchlight on a gross and obvious political job. Its members are of the various committees of the House of Commons. Otherwise an Opposition of cigar-store Indians, or one made up from the spoils of a 


\section{PROTECTION IN CANADA $\mathrm{cH.}$ vi}

raid on Madame Tussaud's, would be as serviceable to the Dominion as the wreckage of the party once led by Sir John A. Macdonald and Sir Charles Tupper. ${ }^{1}$

1 Cf. E. W. Thomson, Wanted a Liberal Conservative Policy, Herald, Halifax, April 18, 1907 ; and further correspondence on same subject, Herald (Conservative), April 23, 1907.* 


\section{CHAPTER VII}

THE BEGINNING OF THE MOVEMENT FOR A NATIONAL POLICY

SHovLd this incidental object-protection to Canadian industries - be produced by the operation of the present tariff-1859-and branches of native industry be created which could not have equally prospered without protective duties, it may be found when the financial condition of the province might enable the Government to reduce their import duties that a class of interests will have grown up which will impose a very serious obstacle in the way of a return to a sounder commercial policy, and that a system of taxation adopted for the legitimate object of revenue may be continued for the mischievous purpose of protection.-J -JMES Воотн.

I CALL these protected industries, infant industries, because they always require protection; and the more protection you give them the more protection they want.-Sir WiLfrid LaURIER.

THe critical or epoch-making period in the fiscal history of Canada lies between the adoption of free trade in England in 1846 and Confederation in 1867. It was in 1846 that Canada secured her fiscal freedom. It was in 1858 and 1859 that she freely asserted herself, 
and first enacted tariffs to protect Canadian manufacturers alike against British and American competition. Cayley and Galt were the Finance Ministers responsible for this new attitude towards England. It was Galt who bluntly told the Colonial Office that Canada in her tariff legislation intended to act as she deemed best for her own interests. Macdonald, after Confederation, only carried further the protectionist policy of Galt ; while Sir Wilfrid Laurier, who has been in power since 1896 , is responsible only for the continuance and expansion of the policy which Macdonald had developed, and for the complete abandonment of the old position of the Liberal party towards protection.

The liberalising amendments to the British Possessions Act of 1833, made by Parliament at Westminster in $1846,{ }^{1}$ left the North American colonies free to enact their own tariffs without being obliged to consider how their changes might affect imports from Great Britain. Robinson was Inspector-General in the Administration of the United Provinces that was in power in 1847, when the first tariff under the new conditions was enacted. "The British Possessions Act," he told the Legislature, in explaining to it its new powers, "leaves the province free to pass such enactments with regard to duties and trade as may be found best suited to her wants and position, and to enable her to meet on terms of friendly 
reciprocity any advances which the neighbouring Republic may be disposed to make for the mutual encouragement of industry and trade, and the development-undisturbed by artificial influences-of the resources peculiar to each country." 1

Acting under these powers the Legislature in 1847 revised the enactments under which import duties had hitherto been imposed, and repealed several laws which were not necessary when the fiscal system of Canada was no longer interwoven with that of Great Britain. The new freedom brought a fresh start for the province in fiscal legislation, and without loss of time three new departures were made: (1) The differential duties in favour of Great Britain were repealed, although not without opposition from members of the Legislature, who were afraid that the change would weaken the connection with Great Britain and increase commercial intercourse with the United States $;^{2}$ (2) freedom of trade was made possible between Ontario and Quebec and all the other British North American provinces; and (3) duties, now uniform on imports from Great Britain and non-British countries, were increased. Under the old tariffs duties had been five per cent. Many of these duties were increased from five to seven-and-a-half per cent; in some instances to twelve-and-a half per cent; while on articles of luxury, such as pickles, preserves, and confectionery, there

1 Mirror of Parliament, March 24, 1847.

${ }^{2}$ Cf. ibid. 


\section{PROTECTION IN CANADA сн.}

were duties in the tariff of 1847 as high as fifteen and twenty per cent. ${ }^{1}$

Even before the British North American provinces had secured their fiscal freedom by the legislation at Westminster of 1846 -in the session of the Canadian Legislature that immediately preceded the fiscal changes in England - it had become the policy of the Provincial Government to frame the tariff in the interest of Canadian industry. It was not possible in 1845 to enact protective duties. The British Government would have disallowed any such legislation. But it was possible for the Legislature to reduce the duties on raw materials; and in 1845 the first step was taken in this direction. "Every encouragement," said Robinson, who, as InspectorGeneral, moved the second reading of the tariff bill, "will be given to home manufactures; and for this purpose the duty upon raw materials will be reduced to one per cent, for merely statistical purposes." 2

In this Act of 1845 may be traced the origin of what since 1879 has been known in the Dominion of Canada as the National Policy. But in 1845 there were no manufacturers in Ontario or Quebec, in the presentday acceptance of the word. There was at that time only one blast furnace in Ontario-the Marmora plant at Long Point, with an output of not more than three tons 
a day; and iron was being made on an even smaller scale at Three Rivers in Quebec. ${ }^{1}$ Neither in Ontario nor Quebec was there a single cotton or woollen mill. There was then no organised protectionist movement in or out of the Provincial Legislature; and it is impossible to discover any protective tendency in the increases in duties which were made in the tariff of 1847 . It is the most simple and least complicated tariff on the statute books of Canada. So far as can be traced, it was intended exclusively for the raising of revenue-one of the two or three tariffs enacted between 1846 and 1906 to which that description can be applied. None the less this tariff of 1847 -this first exercise of her fiscal freedom by Canada-at once brought British manufacturers and exporters into antagonism to the government of the province, and elicited the first of a series of British protests against the fiscal policy of Canada. These protests, begun in 1848 , were continued until as late as 1887 . By 1887 , after eight years of the National Policy that is associated with Macdonald and the Conservatives, it had at last come to be realised in England that protests in Parliament-in the House of Lords as well as in the House of Commons - or to the Colonial Office, or directly to ministers at Ottawa, were all unavailing. 1848 .

1 Cf. Sullivan's Lecture at Hamilton, 1847, and Globe, April 19, 
The protests of 1848 were from Glasgow. They were made to Earl Grey, who was then Secretary of State for the Colonies, by the ironfounders and the merchants, manufacturers, and shipowners of the city. The ironfounders complained in their memorial that the increase in duty.on cast-iron from five to twelve-anda-half per cent was intended to exclude British competition; and they urged that if the tariff of 1847 were sanctioned by the British Government it would annihilate the large and increasing trade in castings which Glasgow had so long carried on with Canada; that it would entail a serious loss on the capital which ironfounders had embarked in the trade, and would deprive a numerous body of working men of one of their means of livelihood. The principle of the new Canadian tariff, it was objected, was opposed to the free trade legislation adopted by England. That legislation, Grey was reminded, had for its object the abolition rather than the extension of commercial restrictions; and the Glasgow ironfounders submitted that while the Canadian Act was inconsistent with the British fiscal system, it was also extremely unjust to manufacturers in Great Britain, after they had been deprived of protection at home, that, instead of enjoying increased facilities of trade, they should be excluded by "new and totally prohibitory duties from access to the very markets which had previously been open to them." Grey was asked to 
advise the Home Government to withhold its sanction from the Canadian Act of 1847 so far as the additional duty on cast-iron was concerned.

The merchants, manufacturers, and shipowners of Glasgow, in the second of these memorials of 1848, expressed their regret and alarm at what was described as " the formidable augmentation of import duties on British produce and manufactures." They complained that under the new tariff the average rate of duty was twelve-and-a-half per cent, and they contrasted these duties with those levied on British manufactures in the East and West Indies and in Australia, which were only threeand-a-half per cent. They complained also that by the new tariff Great Britain was placed in a more unfavourable position as regarded trade with Quebec and Ontario than the other British colonies in North AmericaNew Brunswick, Prince Edward Island, Nova Scotia, and Newfoundland. The Canadian Act of 1847 repealed the old differential duties in favour of Great Britain; and it was complained in the second of these memorialsthat from the Glasgow merchants, manufacturers, and shipowners-that this change " proposes to place the mother country in a more unfavourable position than the United States." "We shall deem it a hardship," continued the memorialists, "if, as British subjects paying taxes, a portion of which is expended on the government and defence of 


\section{PROTECTION IN CANADA сн.}

that colony, our goods shall be admitted on less favourable terms than those of the United States manufacturer, who contributes nothing to that expense, and who may thus by unfair competition be enabled to drive the British merchant and manufacturer out of that colonial market." "For these reasons, as well as for the maintenance of the British connection in America," the memorialists prayed that when the Act of 1847 should come under Grey's consideration it might not receive the assent of the Crown.

Both the Glasgow memorials were dated January 29, 1848. Before they were submitted to Grey the Act of 1847 had been confirmed. Grey forwarded the memorials to Elgin, the Governor-General, on February 11, reminding him that they had been submitted after the decision of the Government to advise the Queen to confirm the Act had been taken, and requesting him to bring the complaints of the memorialists under the notice of the Provincial Legislature. In a later despatch, dated March 31, however, Grey returned to the subject, and explained to Elgin the views which Lord John Russell's Government entertained. "In advising the Queen to assent to the Act," he wrote, "the Government were not unmindful of the objections which would probably be urged by the manufacturers and others in this country to the increased rates of import duty to which many articles of British manufacture are made liable. But 
aware of the importance attached by the Provincial Government to an early decision on the Act, and that the revenue of the colony for the present year was in a great measure dependent on the duties to be levied under this tariff, we were unwilling to offer any impediment to the Act receiving Her Majesty's sanction, preferring to leave these objections to be considered and dealt with by the Provincial Legislature. The duties which are more particularly complained of are those imposed on leather, leather manufactures, on cottons, on the staple manufactures of cotton, on linen, woollen, hardware, and on some specific articles, such as silk dresses, scythes, and axes." I

"Her Majesty's Government," continued Grey, in this letter to Elgin of March 31, " readily acknowledge the propriety of leaving to the colonists the task of raising the revenue which they may require by such methods of taxation as may appear to them most expedient; and in the present case we disclaim any wish to interfere with their liberty of action in this respect, for the sake of protecting the exclusive interests of the British manufacturers. But if, as alleged by the complainants and as in some duties would

1 On men's boots the duty was two shillings per pair; on women's boots and shoes, six shillings and sixpence per dozen; on manufactures of leather not otherwise described, ten per cent ad valorem; on cottons, linen, woollens, and silk, seven-and-a-half per cent; on castings, hardware, axes, and scythes, twelve-and-a half per cent.-Statutes of Canada, 10 Vict. c. 31. 


\section{PROTECTION IN CANADA сн.}

appear to be the case, any of the duties comprised in the tariff have been imposed not for the purpose of raising revenue, but with a view to protecting the interests of Canadian manufacturers, Her Majesty's Government are clearly of opinion that such a course is injurious alike to the interests of the Mothercountry and to those of the colony. Canada possesses natural advantages for the production of articles which will always exchange in the markets of this country for those manufactured goods of which she stands in need. By such exchange she will obtain those goods more cheaply than she could manufacture them for herself; and she will secure an advantageous market for the raw produce which she is best able to raise. On the other hand, by closing her markets against British manufactures, or rendering their introduction more costly, she enhances the price to the consumer; and by the imposition of protective duties for the purpose of fostering an unnatural trade, she gives a wrong direction to capital, by withdrawing it from more profitable employment, and causing it to be invested in the manufacture of articles which might be imported at a cost below that of their production in the colony; while at the same time she inflicts a blow on her export trade by rendering her markets loss eligible to the British customer."

"You will," was Grey's final injunction to the Governor-General, "remind the Provincial 
Legislature that the abandonment by this country of her former restrictive system has left the British merchant at liberty to draw his supplies from those markets of the world from whence he can procure them most cheaply. If the merchant finds that by exporting his goods to Canada they produce him in return large quantities of corn, and thus yield a greater profit than they would if exported to any other country, he will, of course, give the preference to Canada. But if by reason of increased import duties these goods produce a diminished return, the result will be either that the Canadian farmer must submit to a proportionate reduction in the price of his produce, or the British manufacturer must resort to another market. It is obvious, therefore, that it is no less the interest of Canada herself than of Great Britain that this tariff of import duties should undergo a careful revision."

'I'he tariff of 1847 underwent no such revision as Grey suggested in his letter of 1848 . There is no evidence that it had been framed in the spirit attributed to it by the Glasgow memorialists. It was re-enacted in April 1849, with duties at twelve-and-a-half per cent as the general scheme, and with duties on raw material at two-and-a-half per cent; and in this year were first embodied in the tariff the clauses in which an offer of reciprocity in

1 Sessional Papers, 1849, Canada ; Appendix to vol. viii., Jouruals of the Legislative Assembly of the Province of Canada. 
natural products was made to the United States. ${ }^{1}$ Previous to the enactment of this second Canadian tariff-that is, up to April 1849-there had been no organised movement for protective duties; but between the cnactment of the tariff of 1847 and Grey's correspondence with Elgin in March 1848, there had occurred an event which is a landmark in the fiscal history of Canada. The first public meeting at which protection was advocated had been held at Hamilton, now a city of sixty thousand inhabitants, and for half a century one of the great strongholds of the protectionist movement in the Dominion. The meeting was convened on November 17, 1847 , to hear a lecture by R. B. Sullivan, afterwards of the Ontario Bench, on the connection between agriculture and manufactures of Canada. Rarely can a lecture have had more influence than this at Hamilton in 1847 . It was published in book form in 1848; and in 1852, when Clark Gamble, of Toronto, was among the foremost advocates of protection in the Provincial Legislature, he quoted in full Sullivan's protectionist arguments, and again reprinted most of the lecture in the report of his speech in the House of Assembly that was circulated in pamphlet form broadcast over the province.

"What I find fault with," said Sullivan, in urging that manufacturing should be en-

1 Cf. Statutes of Canada, 12 Vict. c. 3, and Globe, November 23 1853. 
couraged in Canada as it was in the United States, "is a state of things that leaves this country without moneyed capital of its own. This is produced by our not having manufacturing enterprise and capital here. Our manufacturing towns are in Great Britain and the United States, whither the profits of our industry flow, without our having the benefit of capital in the country, creating, reproducing more capital, as it should be under a better system." "I do not like," he continued, "to see our hatters importing hats, and shoemakers selling foreign shoes, and tanners offering foreign leather as superior articles. We pay freight and duties and profits upon these importations, apparently because it requires less contrivance to buy than to construct."

Sullivan, in 1847, was as little disposed to discriminate in favour of imports from England as were the Canadian manufacturers who complained of British imports to the Tariff Commission of 1905-6. . Like the manufacturers, who between 1904 and 1906 successfully agitated for a whittling down of the British preference of 1897 , he classed everything not made in Canada as foreign, and was just as anxious to exclude imports from England as from the United States. "We walk on carpets and sleep under blankets," he said, "made in distant England, while our farmers sell their wool to American peddlers to pay a heavy duty on being reimported 
here, manufactured into cloths and satinette. The great Lord Chatham, in the fire of his patriotism for England, said he would not have the plantations in America make a hobnail for themselves. What a pattern for a plantation in this country of Canada, where this very figure of exaggerated hyperbole is true to the letter, as we import our hobnails direct from Birmingham and Sheffield."

The tariff of 1847 was ready for the royal assent in July. It seems probable that by November there had been news in Canada of the opposition which the increases in duties had aroused in Glasgow; for Sullivan told his audience at Hamilton that the merchants of Glasgow, Liverpool, and London still regarded Canada as a plantation. "The profits on the manufacture of the goods used by us," he said, " accumulate in Birmingham, Sheffield, Manchester, Glasgow, Boston, and Pittsburgh - to all these places we bear the same relation as the negroes at the Bight of Borneo: we are not colonists. We are not in England nor in an English colony, but in one of $\mathrm{Her}^{\circ}$ Majesty's plantations in America."

Except for the contention that Canada ought not to be a slaughter-market or a dumping-ground for British and American manufactures-a contention which was raised by Canadian manufacturers as long before the National Policy of Macdonald as 1858, Sullivan in this lecture at the Mechanics Institute, 
at Hamilton, in 1847, advanced praetically every argument that has sinee then been in service with Canadian protectionists. To-day the Canadian Manufacturers' Association repudiates the idea that its members have any hostility to British manufacturers. All that they ask of either British or American manufacturers is that they shall establish themselves and their plants in Canada, and compete on even terms with Canadians for the Canadian trade. This plea is not new with the manufacturers of to-day. Sullivan advanced it in 1847, and in the 'fifties and the early 'sixties it was frequently urged by Buchanan, who was then editor of the Spectator of Hamilton, the foremost protectionist newspaper in those days in Ontario. "The English people are wise enough to know," said Sullivan, in urging that if English manufacturers desired Canadian trade they must manufacture in Canada, " that to be good eustomers it is not necessary that we should buy everything we use. They must also see that if they wish to compete with the Americans in this market in many articles it must be by manufacturing here and not in England. They will see that there are fortunes to be made in Canada by manufactures, as well as comfort and independence by agriculture. When they are convinced of this we shall have villages and towns and cities maintained by real, beneficial, and legitimate commerce; when this is the case we shall import more in amount than we do 
now, because we shall be better able to afford it." 1

The history of the protectionist movement between 1846 and Confederation is of necessity confined to the Provinces of Ontario and Quebec. It was only in the decade that witnessed Confederation that manufacturing was begun in Nova Scotia and New Brunswick. There has never been any manufacturing in Prince Edward Island; and until the Laurier Government came into power in 1896, and its bounty legislation galvanised into existence the steel plants at Sydney, Cape Breton, the Maritime Provinces were strongly free trade in sentiment, and sent many men to the House of Commons at Ottawa who were hostile to the National Policy. At Confederation the Maritime Provinces were apprehensive of the protectionist movement in Quebec and Ontario ; and it was to allay this apprehension that promises were made to them by George Brown and other advocates of Confederation, that duties in the Dominion tariff should never exceed fifteen per cent. ${ }^{2}$ When Macdonald adopted the National Policy associated with his name, and made his appeal in 1878 to the electors of the Dominion to return him to power to put that policy into operation,

${ }^{1}$ Lecture delivered before the Mechanics Institute of Hamilton, November 17, 1847, on the Connection between the Agriculture and the Manufactures of Canada, by the Hon. R. B. Sullivan, Hamilton, 1848.

${ }^{2}$ Cf. Speech by Mr. A. H. Gillmor of New Brunswick, House of Commons Debates, April 11, 1890. 
one of the arguments used by Sir Charles Tupper of Nova Scotia, to offset the opposition to protection in the Maritime Provinces, was that it was only by the enactment of a protectionist tariff that the United States could be compelled to renew the treaty of reciprocity, which from 1854 to 1866 had been of such great advantage to Nova Scotia and New Brunswick. ${ }^{1}$

Before 1879 there was no movement for protection in the Maritime Provinces. There was certainly no such organised movement as there was in Ontario ; although in 1849 , when Gesner published his "Industrial Resources of Nova Scotia," he embodied in it a plea for protection. Gesner urged that industry in Nova Scotia must be protected to stay the emigration of the younger men to the New England States. "It is in vain to suppose," he wrote, "that a free-trade system will be beneficial to a new and struggling colony which has nothing to export but raw materials. It is rather calculated to enrich an old commonwealth, whose people by their skill and labour make such raw materials valuable, and then return them for consumption. The result of the system has been that the suppliers of the raw material at last become hewers of wood and drawers of water to the manufacturers." 2

1 Cf. Speech by Mr. Wm. Paterson of Ontario, House of Commons Debates, April 9, 1890 ; and speech by Mr. James Mitchell of New Brunswick, House of Commons Debates, April 11, 1890.

2 Gesner, Industrial Resources of Nova Scotia, p. 218. 
To some extent Gosner was to Nova Scotia what, before Confederation, Sullivan and Buchanan were to Ontario. But until $\mathrm{Mr}$. Fielding converted Nova Scotia to protection by bountiful largesse to the iron and steel industry of Cape Breton, the Maritime Provinces paid little heed to Gesner, or any other advocate of protection. Except as concerns the coal industry, which was first protected in the tariff of 1870 , the protectionist movement secured but slight foothold east of the province of Quebec until the National Policy of Macdonald had been adopted and extended by the Liberal Government. New Brunswick, Nova Scotia, and Prince Edward Island, like the United Provinces, secured their fiscal freedom in 1846; but between then and Confederation in 1867 import duties in the tariffs of these provinces never exceeded twelve-aud-a-half per cent. This was the highest rate of duty levied in New Brunswick. In Nova Scotia duties never exceeded ten per cent; while in Prince Edward Island they were never for long more than seven-and-ahalf per cent. All these duties were for revenue only, and the Maritime Provinces were never in conflict with the Colonial Office as to the aims of their tariff legislation.

Not until 1852 was there any organised movement outside the Legislature of the United Provinces for protection. That year, however, is memorable in the annals of the movement; for in September there was a 
convention of delegates of boards of trade, with Hugh Allan of Montreal as chairman, at which protection for domestic industries was urged on the Government. ${ }^{1}$ There was also a debate in the House of Assembly on the National Policy ; ${ }^{2}$ and in the same session of the Legislature the free list in the tariff was amended on National Policy lines, and Hincks, who was then Inspector-General, and who had been editor of a free-trade newspaper in Montreal, avowed himself a protectionist. ${ }^{3}$

Since 1845 it had been the policy of the Government to admit raw materials for manufacturers at reduced rates. In the tariff of 1849 there was a small list of these articles which were admitted at the rate of two-anda-half per cent. ${ }^{4}$ In 1850 the Government obtained power to add to this list by orders in council. ${ }^{5}$ In 1852 Hincks defended this policy of changes in the tariff by order in council. Its object, he said, was to enable a manufacturer who introduced a new manufacture into the province to make application to the Government for the reduction of the import duty on the raw material, on showing that he was likely to compete successfully with foreign manufacturers. Hincks admitted that tariff changes with this aim were inconsistent with free trade, ${ }^{6}$

1 Cf. Globe, September 15, 1852.

2 Cf. Journals of the Legislative Assembly, October 28, 1852.

3 Cf. Globe, September 25 and November 9, 1852.

412 Vict. c. 1.

${ }^{6}$ Cf. Globe, November 9, 1852. 


\section{PROTECTION IN CANADA сн.}

and told the House that he had abandoned his free-trade views. The Government in which he was Inspector-General also threatened in 1852 a tariff war against the United States if reciprocity were not conceded, $-\mathrm{a}$ threat which drew from the Globe the comment that "Mr. Hincks has jumped Jim Crow; and from being a thorough-paced free trader has gone over to protection and retaliatory principles." Hincks made no changes in the general tariff list in 1852 in the interest of Canadian manufacturers. $\mathrm{He}$ proposed no protectionist duties. Changes in this direction were not avowedly made until 1858, when Cayley was Inspector-General. Hincks, however, was the first Canadian Minister of Finance to avow his abandonment of tariff-forrevenue-only principles; and thus, as early as 1852, to establish a precedent for Mr. Fielding's abandonment of his former political principles when he became Minister of Finance in 1896. The debate of 1852 - the first on the National Policy of which there is any recordwas on a motion by Clark Gamble, a Toronto lawyer, who represented the South Riding of York in the House of Assembly. He moved ${ }^{1}$ that it was expedient to revise the tariff, "in order that the revenue derivable therefrom may be raised in such a manner as to foster and encourage those branches of native industry for which this country possesses natural advantages." Gamble advocated a 
protective tariff which should not be confined in its application to goods imported from the United States only, but made to apply to all imports, "come from where they may, or whatever their place of origin, with the single exception of our sister colonies in America."

Such a revision of the tariff, he urged, naturally suggested itself as wise and proper whenever the interests of Canada, irrespective of those of any other country, were consulted as a paramount consideration. He recalled the British fiscal legislation by which Canada was bound until the amendments to the British Possessions Act of 1846 ; and declared that the sole object of all British legislation, from the early years of George III. down to 1846, was "the promotion of British interests, British manufactures, British commerce, and British shipping - not of Canadian interests, Canadian manufactures, Canadian commerce, and Canadian shipping." Canada's position in 1852 , he contended, was but little different from what it had been before 1846 . "We impose," he said, "high duties on articles we cannot produce, and low duties upon those manufactured articles that we can make for ourselves if we choose to do so."

The duty on tea in 1852 was eighteen-anda-half per cent; on coffee twenty-one-andthree-eighths per cent; on tobacco twentythree-and-one-eighth per cent ; on coarse sugar fifty-one per cent, and on molasses fifty-seven per cent; while on manufactured goods the 
duties were only twelve-and-a-half per cent. Gamble characterised this as British rather than Canadian legislation. "Its object," he went on, "is clearly manifest. It is to compel us to derive our supplies of clothing and other necessaries from them, and thus encourage British manufactures, British carrying trade, and the employment of British capital. Its tendency is evidently to perpetuate the unjust and unreciprocal trade with Great Britain, and our colonial dependence as a consequence."

Gamble quoted from a pamphlet of Joshua Gee, published in 1750, laying much emphasis on Gee's contention that manufactures in the American colonies should be discouraged or prohibited; and declared that Gee-ism still dominated the fiscal policy of Canada. $\mathrm{He}$ asserted that British merchants and exporters considered any of their refuse stock good enough for Canada; and that people in England knew little about Canada, and cared less. "Witness," Gamble continued, "the abandonment of our interest on the repeal of the corn laws. It has been repeatedly stated in this House, and with great truth, that one word previous to that repeal would have insured us free ingress for our raw products into the markets of the United States. One single clause retained in the navigation laws-its repeal of no consequence to Great Britainwould have insured to Quebec the largest shipbuilding trade in the world. Our interests were too contemptible to be remembered. 
That one word was not spoken; that clause was repealed. Twelve months after this repeal of the corn laws we were permitted to repeal the differential duties. Was that overlooked in England? Oh no ; Lord Grey, almost in the words of Joshua Gee, tells us what we should have done." Grey had told them in 1848, continued Gamble, that it was obvious that it was not less the interest of Canada herself than of Great Britain that the tariff of 1847 should undergo revision. ${ }^{1}$ Gamble agreed that the Canadian tariff should be revised. "But," he added, "for a very different purpose, and a very different object from that desired by his lordship, who, with Joshua Gee, was keen for having the raw produce, a large quantity of corn, not onefourth part of which should redound to our profit, because paid for in cheap manufactured articles of any ordinary sort, oldfashioned with people in England, but newfashioned enough for us."

"'The object of all this," continued Gamble, in commenting further on Grey's letter of 1848 , " is manifest. It is to persuade us, now that resort can no longer be had to force, to adopt free-trade theories, and continue the old system of commercial legislation, by which England would retain the more profitable employment of manufacturing for the industry of her people, at the expense of the industry of the people of Canada, who would thus be

1 Grey's letter to Elgin, March 31, 1848. 
CH.

compelled to follow the less profitable business of producing the rough or raw materialbulky articles, bulky in proportion to their value-to be carried in her ships, at the cost of the Canadian farmer and producer. The object of British legislation in our commercial affairs has been to build up British interests and not Canadian, and thus perpetuate our dependence on them for all manufactured articles of first necessity. That object has been fully attained. With every natural facility, and the bounties of nature strewed around us in the utmost profusion, with elements of wealth on every hand, we are still but an agricultural people, and therefore a poor people-without manufactures, without railroads, and without ourselves possessing the means wherewith to build them. No wonder we are obliged to have recourse to English capitalists and English contractors for our contemplated Grand Trunk line; and obliged, if built at all, to construct it at double the expense it would otherwise cost. Those who are dependent upon England for their clothing and knives and forks and spoons, must also necessarily be dependent upon her for their railroads."

The advocates of a National Policy for Canada after 1852 , continually pointed to the industrial progress of the United States, and attributed it to protection. Gamble was one of the earliest, if not the first member of the Legislature to urge Canada to follow the 
example of the United States. "Look," he said, in this speech of October 28, 1852, "at the example of the United States, and behold the effect of American legislation fostering and encouraging American industry. Look at Canada, and behold Canadian legislation fostering and encouraging British industry and not Canadian. That is the whole secret, the reason that Canada is distanced by her better protected neighbour, who understands her true interests, and is governed in accordance therewith; while Canada has been governed for British interests, and British interests only."

The remedy, Gamble insisted, was in Canada's own hands-within her power if she cared to exercise it; and the remedy he urged on the Legislature was "such a revision of the tariff that the revenue raised by import duties might be arranged to foster and encourage our industry." 1 Gamble moved that the House resolve itself into a committee to take into consideration his resolutions. ${ }^{2}$ The motion was given "the three months' hoist"; an equivalent to the adoption of a motion for the previous question. Gamble's speech is, however, another landmark in the fiscal history of Canada; for, as far as I can discover, it was the first earefully elaborated plea for a National Policy made in the Legislature of the United Provinces.

1 Summarised from a reprint of Gamble's speeeh of October 28, 1852 , published at Toronto in 1852 .

2 Cf. Journals of the Legislative Assembly, October 28 and November 4, 1852. 
In the next session of the Legislature-in April 1853-there was another debate on the National Policy. Ridout, who opened it-like Gamble in 1852-adrocated a protectionist tariff, regardless of how it might affect trade with Great Britain. At this time the outlook for reciprocity at Washington was still unpromising; and, as in 1852, expression was given to the soreness left by England's failure to insist on reciprocity for Canada when in 1846 the fiscal system was so amended as to admit grain from the United States at a nominal duty. Gamble again advocated the policy expounded in his speech of October 1852, and declared himself for Canada first; then for Great Britain; and for the United States when he could not help it. Again he pointed to the industrial progress south of the boundary line; and insisted that it was manufacturing that had made New England what it was. Every manufactory, he argued, became a market for the farmer-a market that was constantly increasing. That was why the United States were flourishing; and if Canada desired to benefit her farmers she must ereate a home market, and to that end the tariff must be so revised as to encourage Canadian manufacturers. ${ }^{1}$

Before this time Sullivan and Buchanan had argued that a home market was essential for the prosperity of Canadian agriculture; and as early as this in the debates in Parlia-

$$
{ }^{1} \text { Cf. Globe, April 21, 26, } 1853 .
$$


ment the plea was made that protection would create a home market for the farmer. In the fifty-four years that have elapsed since Gamble introduced the argument in 1853, the same argument has been persistently put forward by protectionists in Canada. It is in service to-day, although since it was first advanced millions of dollars have been spent by Canadian Governments on immigration propaganda in Europe and in the United States; and as a recent result of the propaganda for the filling up of the prairie country west of Lake Superior, the area under grain in the Provinces of Mauitoba, Saskatchewan, and Alberta was increased from three-and-a-half million acres iil 1900 to nearly eight million acres in $1906 .^{1}$

In the fiscal debates of 1852 Hincks recanted the opinions which he had held when he was editor of the Montreal Pilot. He had, he then stated, ${ }^{2}$ formerly been as staunch an advocate of theoretical free trade as Young, who in 1846 organised the Free Trade Association of Montreal; but his views had been changed by experience, and he was now convinced that to legislate irrespective of other nations was a wise course. ${ }^{3}$ This state-

${ }^{1}$ Totals for three Provinces-

$$
\begin{aligned}
& \begin{array}{cccc}
\text { Wheat . } & \multicolumn{1}{c}{1900} & 1906^{\circ} \\
& . & 2,495,467 & 5,063,800
\end{array} \\
& \text { Oats . . . } 883,390 \quad 2,322,646 \\
& \text { Barley . . . . 162,557 } \quad 529,160
\end{aligned}
$$

-Manitoba Free Press, Winnipeg, May 16, 1907.

2 House of Assembly, September 20, 1852.

3 Buchanan, The Relations of the Industry of Canada with the Mother Country and the United States, p. 121. 
ment was made by the Inspector-General at a time when he was urging retaliation against the United States with a view to quickening the negotiations at Washington for reciprocity. But while Hincks had thus abandoned the free-trade convictions of his journalistic days, he was not in 1853 prepared to go as far in the direction of protection as Gamble or Ridout; for in the debate which had been begun by Ridout, he declared his opposition to any duties on British manufactures except for revenue. He complained also that the advocates of a Canadian policy had been most ungenerous to the British statesmen who were responsible for the fiscal measures of 1846 . It was true, he said, that when the corn laws were abolished he thought the British Government failed in not trying to get the advantage of reciprocity not only for the colonies but for Great Britain herself, " but in 1846 there was little time for diplomacy, for a starving people had to be relieved." 1

There was no increase of duties in 1853 . In response, however, to the agitation of the boards of trade of 1852 for discrimination in favour of the St. Lawrence route, ${ }^{2}$ there was inserted in the Tariff Act $^{3}$ a clause by which appraisers were directed to levy duty on the value of the goods in the principal markets of the country from which they last came. In this way British imports that reached Canada

1 Cf. Globe, April 25, 1853.

${ }^{2}$ Ibid. September 15, 1852.

316 Vict. c. 85. 


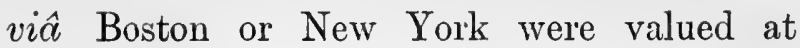
American prices, the object of the clause being to divert trade from United States ports to Quebec and Montreal. This was one of the enactments of which complaints were made at Albany and Washington in the early years of the operation of the Elgin-Marcy Treaty. It aroused the opposition of the Globe-then edited by George Brown,-which characterised it as "the grossest injustice, done in a despicably mean and tricky manner." 1

For importers this new method of computing duties was undoubtedly a hardship, as for four or five months in the winter the St. Lawrence route is closed. It was an enactment that worked even more inconvenience to merchants in Toronto, Hamilton, and London than would result to those cities to-day should success attend the movement which has been on foot in St. John, Halifax, and Montreal since 1898 to induce Parliament to deny the British preference to all imports which do not come direct to a Canadian port. To-day there are railways connecting the Maritime Province ports with Montreal and the cities west of Montreal. In 1853 there was no Intercolonial Railway comnecting New Brunswick and Nova Scotia with the Province of Quebec, and no Canadian Pacific short line from St. John to Montreal. Importers in Montreal and Toronto were consequently compelled, after this enactment was passed, to crowd their warehouses

1 Globe, April 10, 1853. 


\section{PROTECTION IN CANADA сн.}

while the St. Lawrence navigation was open, or submit to penalties if they imported through Boston or New York.

By another clause in the tariff of 1853 it was provided that on packing-cases, on which hitherto in most instances no duties had been charged, ${ }^{1}$ ad valorem duties should be levied at the same rate as on the imports contained in the cases $;^{2}$ and in later years, certainly since 1879, Canadian manufacturers have been careful to secure that duties shall be paid on packing-cases. In 1906, when the British preference clauses were in committee in the House of Commons, the ultra-protectionists, who are outspoken in their opposition to any tariff concessions to British manufacturers, insisted that the cost of packing should not be included as part of the twenty-five per cent of bona fide British labour, which must be added to partly-manufactured goods before they can come in under the British preference.

"To my mind," said one of these opponents of the preference, "the whole idea of the preference is this, that while favouring skilled artisan labour of Great Britain, you should not go beyond that. You should not take into account rough labour, such as the work of making packing-cases, which can be distinguished from the finer work of the artisan. Yet you are placing on the same level the rough labour of the man who handles an axe or a saw and the skilled labour of

1 Cf. 12 Vict. c. 1.

${ }^{2}$ Cf. 16 Vict. c. 85. 
the artisan who is producing the goods. If a large proportion of the cost is run up in that way there is no protection at all to the woollen manufacturer in this country. I think that no computation should be allowed either for the outside wooden boxes or for the interior boxes made of cardboard." 1

The few changes that were made in the tariff schedules in 1853 were with the intention of reducing taxation. The duties on sugar were reduced. The duty on salt was repealed, so that there is ground for assuming that the duties on packing-cases were a protectionist expedient.

The free list in the form in which it now exists in the Canadian tariff-total exemption from duties as distinct from low or nominal duties-dates from 1854. From as early as 1845 it was the policy of the Provincial Government to reduce the rates on raw materials. The rate was then fixed at one per cent, merely, as Robinson, InspectorGeneral in 1845, explained, for statistical purposes. This rate was continued until 1849, when it was advanced to two-and-ahalf per cent. In 1854, however, a free list, in which there were fifty items-mostly raw materials-was enacted. ${ }^{2}$ Year by year since 1854 this list of raw materials or partly manufactured materials, not produced in Canada but used by Canadian manufacturers,

1 House of Commons Debates, December 14, 1906.

218 Vict. c. 5 . 
has been extended, until in the last tariff, ${ }^{1}$ notwithstanding the fact that between 1879 and 1907 numerous articles on the free list were transferred to the dutiable and protected schedules, because they were then made in Canada, the free list contained one hundred and thirty items.

From 1856 to 1862 agriculture and trade in Ontario and Quebec were much depressed, and interest and other charges on the canals and other public works made increasingly large calls on the revenue of the United Provinces. As a result of these conditions duties were increased in the tariff of 1856 from twelve-and-a-half to fifteen per cent. In a few instances, as in the case of manufactures of leather, they were increased to twenty per cent $;^{2}$ and between the enactment of this tariff and that of 1858 , in which duties were again increased, ${ }^{3}$ the Association for the Promotion of Industry - the first protectionist organisation in any of the British North American colonies-had begun its propaganda and achieved its first parliamentary success.

It was in April 1858 that Buchanan, who at this time represented Hamilton in the Provincial Assembly, organised the Association. Since then, for a period that now extends to half a century, Canada has never been without an organisation whose aim is to uphold and extend the protective system. After

1 Customs Tariff of 1907.

${ }^{2}$ Cf. 19 Vict. c. 10.

${ }^{3}$ Cf. 22 Vict. c. 76. 
1876, when Macdonald became a protectionist and carried the Conservative party over to protection, the National Policy League continued the propaganda of the Association for the Promotion of Industry; and when the National Policy League came to an end, its work was taken up in 1886 by the Canadian Manufacturers' Association, and has since been continued with increasing persistence and vigour. ${ }^{1}$ This Association, like the Association for the Promotion of Industry, drew its inspiration from Hamilton, which may be regarded as the Shefficld or Birmingham of Canada. The Manufacturers' Association is the strongest and most permanent of these protectionist organisations; for most of its twenty-two hundred members are directly and pecuniarily interested in the continuance of protection, and in building higher the tariff wall against all outside competition-American or British-and its most active and most powerful standing committee is that to which are delegated all matters directly or indirectly comnected with the protective tariff.

The call for the meeting at which the Association for the Promotion of Industry was organised was issued from Toronto, on March 24,1858 . Sixty-two manufacturers or publicists, such as Isaac Buchanan of Hamilton and Mackenzie Bowell of Belleville, ${ }^{2}$ responded,

1 Cf. Prominent Men in Canada, W. E. Sandford, p. 112.

2 Now Senator Bowell, and for a brief time in 1896 Premier of Canada. 
and were in attendance at St. Lawrence Hall, on April 14. W. B. Jarvis of Toronto, who was in the chair, and Buchanan were the principal speakers. Jarvis reported that he had been in communication with many manufacturers in the province, and had ascertained that there was an almost unanimous opinion among them that it was necessary to make such alterations in the tariff as would protect Canadian industry. These manufacturers had informed him that many articles then imported could be made in Canada, and they complained that if articles made in Canada were sent into the United States they had to pay duties that were almost prohibitive. Buchanan read a letter from a manufacturer at Manchester inquiring as to the resources of Toronto, Kingston, and Montreal for the manufacture of cotton goods; asking also if coal were cheap, if wool was to be obtained, and whether Canadians were disposed to give a preference to Canadian manufactures. There were hundreds of manufacturers in England, added Buchanan's Lancashire correspondent, who only wanted to be assured that there were openings for them in Canada to remove their machinery to Canada. Commenting on this, Buchanan insisted that England must see that centralisation would not stand, and that she must allow any British colony to adopt what economy it might deem proper. ${ }^{1}$

Five resolutions were adopted by the ${ }^{1}$ Cf. Globe, Aprii 15, 1858. 
convention. In the first, acknowledgment was made of "the advantages bestowed on the inhabitants of Canada through the enlightened policy of Her Majesty's Government and Parliament in permitting Her Majesty's subjects in this portion of the British Dominions to deal with every matter touching their material welfare"; but it was asserted that the friends of Canadian industry, from all parts of the province thus assembled, could not shut their eyes to the fact that Canadian legislation hitherto had failed to lay any solid foundation for permanent prosperity in the country. "The prevailing depression of the trade of this province," it was set out in the next resolution, was, in the opinion of the meeting, "greatly owing to the tariff being based on erroneous principles. It admitted the manufactures of other countries that could be made by a class of labour then in Canada, a class of labour that was unfitted for agricultural pursuits, at low rates of duty, while higher rates were charged on articles that could not be produced in Canada, thereby preventing the development of the natural resources of the colony, as well as injuring Canada as a field for immigration."

The third resolution urged that if the tariff were readjusted in accordance with protectionist principles, every class of the community would be materially benefited by the change ; there would be no reduction in the revenue from such a readjusted tariff; while the effect 
of the change would be to "dissipate the despondency perceptible in every quarter; create a feeling of encouragement among capitalists in Canada; draw the attention of foreigners to Canada's magnificent resources for manufacturing, and to the certain improved demand for all kinds of goods made within the colony ; cause a spirit of enterprise to spring up among Canadian artisans; give fresh vigour to the agricultural and labouring population, besides instilling additional confidence in the minds of those who held or were seeking Canadian securities."

By the fourth of these resolutions it was decided to petition the Legislature to remodel the tariff at the session that was then in progress; and by the fifth a general committee, with fifty-five members, was appointed to put themselves in communication with Cayley, the Inspector-General, and the members of both branches of the Legislature who were favourable to the encouragement of home manufactures, "with a view of obtaining a speedy remedy for the grievances under which every department of home industry now suffers."

At this period the Globe was always to the fore in its defence of free trade; and in commenting editorially on the St. Lawrence Hall Convention it dealt with it first from the standpoint of the effect a protectionist tariff would have on the Elgin-Marcy 'Treaty, which had been in operation since 1854, and next 
from the standpoint of Canadian consumersthe standpoint from which between 1858 and 1897 when the Laurier Government adopted the National Policy of Macdonald, the Globe invariably regarded all protectionist inroads on the fiscal system of Canada. "Millions of dollars," it declared, "would not compensate for the loss which would be sustained by Upper Canada should the reciprocity treaty be abrogated." "Manufactured goods," it continued, "have been in demand because the people were rich and could afford to pay for them, yet the manufacturers are now prepared to bring us back to the old condition of things, and hope to recompense themselves by taxes laid on the people for their support. We say they would impoverish the general public by adopting a protective policy, because we have every reason to believe that if we should lay upon American manufactures a duty which should shut them out of our market, the reciprocity treaty would not stand one day longer than would be needful to pass the necessary measure of repeal." 1

Three new departures in the history of the protectionist movement in Canada can be dated from the Toronto Convention of 1858 . In the resolutions then adopted there was advanced a plea that for fifty years has had its place in the protectionist propaganda-a plea that was put forward as recently as the Tariff Commission of 1905-6. It is the plea

1 Globe, April 15, 1858. 
that in Canada there are necessarily increasing numbers of men who are unsuited for farm life - who do not like farming, its toil, its isolation, or who cannot be content with its rewards, - and that it is the duty of the Government to maintain a protective system, that industrial opportunities that shall be certain and remunerative shall be open to the men who prefer life in the cities to life on the farm. "We don't like farming; we prefer industry and business to farm life ; and it is the duty of the Government to see that people on the farms shall be compelled to buy our manufactures and at our price, and thereby keep us profitably employed." This was the attitude that more than once was assumed by manufacturers who appeared before the Commission of 1905-6, to ask that the tariff wall should be built higher than it had been left by the Fielding tariff of 1897 . There was nothing new in this attitude of the Canadian protectionists towards the farmers. It can be traced back at least to the St. Lawrence Hall Convention of fifty years ago.

The beginning of the practice now common at Ottawa of manufacturers waiting on the Minister of Finance-sometimes in public, oftener in private-to urge increases in the tariff can also be dated back to 1858 . In the resolution appointing a committee to wait on the Inspector-General may be discerned the germ of the Red Parlour, the institution in Toronto that was developed by Macdonald, 
and brought into service by the Conservatives between 1879 and 1891 whenever a general election was pending and money was needed for what American political bosses describe as "getting out the vote." I Canvassing members of Parliament in the lobbies and elsewherc to support increases in the tariff also began with the St. Lawrence Hall Convention. From these and other points of view the meeting that Buchanan organised in 1858 stands out prominently in the history of protection in Canada.

The committee that was appointed at the Toronto meeting waited on Cayley on April 16 with a draft tariff. There were seven sections in the draft. In the first it was proposed that all goods, wares, and merchandise not mentioned in the other six sections should remain as they stood in the tariff then in force. In the second section there was a list of articles, thirty-one in number, which it was proposed should be transferred from the free list, or the two-and-a-half per cent or the five per cent list, to lists in which the duties were higher. In the third was an enumeration of raw materials or partly-manufactured materials-thirty-three items in all-which, it was suggested, should go on the free list, or at a rate of duty not to exceed two-and-a-half per cent. Section four was the most significant,

${ }^{1}$ Cf. Sir R. Cartwright's attack on the Red Parlour, and his declaration, in the discussion of its place in Dominion politics, "this whole business of protection is robbery - legalised robbery." -House of Commons Debates, April 11, 1890. 
CH.

as it contained a list of nearly two hundred manufactured articles on which it was urged that the duties should be at the rate of twenty-five per cent-an increase of ten per cent, as most of the articles enumerated were in the fifteen per cent schedules of the tariff of 1856. In the fifth section were books, drawings and engravings, lithographs, music, paintings and prints, on which the duties suggested were ten per cent; cotton manufactures of every description, except yarns and warps; woollen manufactures of all sorts; cordage, lines, twines, hawsers, ropes, and rigging, on which it was suggested that the duties be twenty per cent; and clothing and wearing apparel, made up or partly made, of any material, on which a duty of thirty per cent was recommended. Tea, raw sugar, coffee and molasses were in the sixth section; and the recommendation of the general committee of the Association for the Promotion of Industry was that the duties on them should be reduced to the lowest point that the revenue would permit of. "Other articles now paying specific duties, such as spirits, cordials, wines, and tobacco," reads section seven and last, "might remain as at present, or the duty thereon be increased if necessary." 1

Cayley, to whom belongs the distinction of being the first Canadian Finance Minister to be waited upon by a protectionist deputation,

${ }^{1}$ Cf. Buchanan, The Relations of the Industry of Canada with the Mother Country and the United States, pp. 483-493. 
accorded Jarvis and Buchanan and their colleagues of the committee a sympathetic hearing. His answer to the memorial embodying the resolutions of the convention was that the Government was disposed to carry out the views therein expressed, so far as was consistent with the general interests of the country and the requirements of the revenue. Measures, he added, would be submitted during the session of the Legislature then in progress which, if they did not in all cases meet the views of the deputation, would, he believed, be generally satisfactory. It is Buchanan's chronicle of the proceedings from which I am quoting, ${ }^{1}$ and in this chronicle there is a paragraph which reads curiously like the newspaper paragraphs nowadays sent out from Ottawa after a deputation of protectionists has had an interview with the Minister of Finance. "Several gentlemen present," it reads, "entered into explanations respecting the requirements of their particular branches of trade, and urged upon the Inspector-General and on other members of the Government present the necessity for immediate legislation on this important question."

${ }^{1}$ Cf. Buchanan, Britain the Country versus Britain the Empire, App. B, p. 36 . 


\section{CHAPTER VIII}

THE FIRST NATIONAL POLICY TARIFFS1858 To 1870

Tнв Government is carrying out a scriptural injunction : To him that hath they give, and from him that hath not they are taking away even that which he hath.-David Mills.

IT is the duty, and the sacred duty, of the Government to take from the people only what is necessary to the proper discharge of the public services. Taxation in any other mode is simply robbery-in one shape or another, legalised robbery. - Sir R. Cartwright.

Four months later-in July 1858-when the new tariff was enacted, Buchanan and his associates of the St. Lawrence Hall Convention had the satisfaction of realising that Cayley had kept his promise to the deputation that had waited on him on April 16, and that as a result of the propaganda which was begun at St. Lawrence Hall, and vigorously pushed all over the province in the intervening months, the Association for the Promotion of Industry had achieved an immediate and signal success. Cayley did not accept 
the draft tariff, but he embodied many of the recommendations of the Association in his tariff of 1858, which was carried in the House of Assembly by 68 votes to $28 .^{1}$ In the tariff of 1856 the general range of duties on manufactured goods was fifteen per cent. Only in a few instances were the duties on these imports as high as twenty per cent. In the Cayley tariff the general range of duties was increased to twenty per cent. Duties as high as twenty-five per cent were levied on boots, shoes, harness, and saddlery, and also on leather, clothing, and wearing apparel. Unenumerated goods were made liable to duties at the rate of fifteen per cent. There was a list of partly manufactured goods with duties at five per cent; and in the free list, embracing chiefly raw materials, there were about one hundred and forty items.

The twenty per cent list comprised eighty items - all manufactured articles, most of them of the kind that at this time were imported from England. Among the more important imports on which twenty per cent was levied under the tariff of 1858 were baskets; beads ; blacking; bracelets; candles ; chandeliers and gas-fittings ; cabinet-ware or furniture ; carpets and hearth-rugs; confectionery; chinaware; cutlery; coach and harness furniture; fans and fire-screens; glass ; gilt frames ; guns, rifles, and firearms; jewelry; leather, sole and harness; mattresses; millinery; mowing

${ }^{1}$ Cf. Spectator, Hamilton, July 30, 1858 ; 22 Vict. c. 76. 
and reaping machines; manufactures of cashmere, silk, velvet, and satin ; of brass, copper, leather, and papier-mache; oil-cloths; plated and gilded ware; railway and fencing iron; scales and weights; shawls; spades and shorels; spikes, nails, and locks ; silk, woollen, and cotton embroideries or tambour work; soap; stoves and all other castings; thread, lace, and insertions; and woollen goods.

The debates on the tariff of 1858 are remarkable for the fact that in these first discussions in the Legislature on a protective tariff the argument was raised that protection was necessary to prevent what in later years has been known in Canada as dumping. In recent years the argument has been that it is American manufacturers who dump their wares over the border unless there are enactments to prevent them. The first complaints of dumping - those in 1858-were against English, not American manufacturers. Mathewson, a soap-boiler of Montreal, was prominent at the St. Lawrence Hall Convention, and he was of the general committee then appointed to lobby for protection. By Cayley's tariff duties on perfumed or fancy soap were advanced from fifteen to twenty per cent; and a new duty of a cent and a quarter a pound was imposed on all other soaps. Hitherto the duty had been ad valorem. In justifying the change to a specific duty on the common kinds of soap, Rose, who was then AttorneyGeneral, assured the House that both manu- 
facturers and purchasers of soap had strongly pressed on the Government the necessity of substituting specific for ad valorem duties, because the Canadian market was flooded with the refuse soap of English manufacturers, which had been entered at the customs-houses at prices below those at which soap had ever been sold in England. Rose made this statement in reply to Dorion, one of the Opposition leaders, who had objected to the change in duty; and he wound up his argument by asking Dorion whether, when the manufacturers of Canada were capable of supplying its needs, he was willing that Canada should be made the refuse market of the world. ${ }^{1}$

The phraseology of the protectionist propaganda has changed somewhat since 1858 . During the National Policy era of the Conservatives, high duties were insisted upon by the manufacturers to prevent Canada from being made a "slaughter market." Since the Liberals inherited the National Policy a new phrase has come into service; and there is now a special clause in the tariff, first inserted in $1904,{ }^{2}$ and re-enacted with some amendment in the tariff of 1907, the purpose of which is to prevent Canada from becoming what the protectionists now describe as a dumping-ground for foreign manufacturers.

Mathewson, the soap-boiler of Montreal, is entitled at least to passing mention in a

1 Cf. Globe, July 12, 1858.

24 Edward VII. c. 11, sec. 19. 
history of protection in Canada as the first Canadian manufacturer to raise the cry of dumping; to persuade the Government to adopt his own remedy for dumping; and also as probably the first Canadian manufacturer to derive direct and immediate profit from a tariff which he had been instrumental in inducing the Finance Minister to adopt. ${ }^{1}$

The protectionists were jubilant at their victory of 1858. It showed, declared the Hamilton Spectator, what could be accomplished through determined perseverance and untiring effort. "It will be remembered," it continued, "with what a shout of derision the movement at Toronto was met by a portion of the Opposition press, which attempted to laugh it to scorn, and denounced it as a futile attempt to restore an exploded system of protection, highly detrimental to the best interests of the country. Some three or four journals, among them the Globe and the Leader, laboured most industriously to thwart the aim of the Association. But they soon found that it was useless; for the fecling of the country was with the Association, and the Government wisely yielded to the pressure from without, and conceded the chief demands of the protectionists." "The free traders, so called," continued the Spectator, " have been worsted; and they have probably learned by this time that their nostrums are by no means palatable to the people of this country. What

1 Cf. Globe, July 16, 1858. 
we want is more capital, and a check upon the drainage of money from the province; and this we are in a fair way of obtaining; for the tariff will reduce our importations and retain within the country one-half the amount expended on purchasing goods which we can manufacture ourselves. This is no trivial boon to a country like Canada; besides, our markets will be speedily discovered, and in a full market duties are no taxes. The simple question now is, are we prepared to give up our victory to the political economists? Now we can afford to speak more plainly than men who for a moment would doubt their own loyalty, we being of that class who would stick to the old flag, right or wrong; and we camnot find words sufficiently eloquent to denounce those ignoramuses who would try on old country theories-even if they had been proved in that old and rich state of things - in a new country like Canada. Though this country is not, and we trust never will be, republican, its material interests are the same as those of our republican neighbours. Canada, therefore, wants no untried theory of trade and industry, seeing that we have the actual and dearly-bought experience of the United States." 1

The free-trade view of the Cayley tariff found expression in the Globe as the measure was passing through its several stages in the Legislature. "It is true," it said, at an early

${ }^{1}$ Spectator, Hamilton July $30,1858$. 
stage of the discussions in the House of Assembly, "that some sops are thrown to the protectionists, but they are not judiciously given." " "Mr. Cayley," the Globe commented in its next issue, "has not granted what the protectionists asked for, and has probably disappointed most of those who met recently in convention $;^{2}$ but at the same time he has introduced enough of protection to bring upon himself the condemnation of the advocates of free trade. He said that the new tariff would afford incidental protection, but only a few manufacturers are favoured." ${ }^{3}$ The final comment of the Globe was that Cayley, while professing free-trade principles, "had in fact increased the scale of duties enormously on articles which the poor man uses, for no other purpose than to give a false stimulus to some small branches of manufacturing interest." 4

It is a truism that protectionists are never satisfied. This has been so in the United States; and it has been equally so in Canada. No sooner has one campaign for increased duties been successful than another is begun. It must be so if such organisations as the Association for the Promotion of Industry, the

1 Globe, July 2, 1858.

2 St. Lawrence Hall meeting, April 14, 1858.

${ }^{3}$ Globe, July 3, 1858.

4 Ibid. July 10, 1858. It was at this time, when the first protectionist tariff was before the Legislature, that the Globe published its estimate that in 1858 the number of people engaged in industries which could be benefited by protection was between five and seven thousand. Ninety per cent of the people of Canada, it asserted, lived by tilling the soil ; ten per cent by other pursuits. 
National Policy League, and the Canadian Manufacturers' Association are to live and prosper. It also follows from the fact that when these organisations have discovered that governments are amenable, pressure is brought to bear upou them for fresh concessions.

The demand for more is as old as the first protectionist tariff. Buchanan and his Association began a new campaign as soon as the tariff of 1858 was on the statute book. They issued a manifesto, written by Buchanan, in which he pressed upon Canadians the necessity for continuing the Association for the purpose of defending the ground which had been gained, as well as for obtaining from Parliament the completion of the measures necessary to the promotion of Canadian manufactures. "These," Buchanan continued, "are the abolition at the earliest possible moment of the entire duty on tea and coffee, and such other articles as the United States manufacturers enjoy duty free; and the gradual reduction of the duties on general merchandise which Canada does not produce or manufacture, putting in lieu of these an increase of duty on such goods as are from time to time added to the category of Canadian manufactures." 1

At the St. Lawrence Hall Convention, Buchanan had stated that cotton manufacturers in England were ready to bring their

1 Buchanan, The Relations of the Industry of Canada to the Mother Country and the United States, p. 130. 
machinery to Canada as soon as protection was assured. He returned to this subject in the manifesto that was sent broadcast after the tariff of 1858 had been enacted; and expressed his conviction that coarse cotton fabrics would be included in the category of Canadian manufactures "so soon as manufacturers in England and the United States could be assured of an incidental protection of from five to ten per cent more than the present duty." 1

Students of protectionist legislation cannot fail to have observed that most tariff acts have, somewhere within their four corners, clauses or schedules intended to bestow extra largesse on some favourite industry-on some industry which is able to exercise what in Canada as well as in the United States is described as a political pull. The tariff history of the United States is full of illustrations of the power of men in some particular industry, at some particular time, to obtain pretty much what they asked from Congress. In the early days of American protection, as far back as the 'fifties of last century, coal was one of these political favourites. Iron next came into this position for much the same reason as coal-because with the exception of New York, Pennsylvania has more members in Congress than any other State. Later on wool, woollen manufactures, silk,

1 Buchanan, The Relations of the Industry of Canada to the Mother Country and the United States, p. 130. 
tin-plate, and chinaware had their turns as favourites.

The tariff history of Canada is much the same story, with soap, sugar, coal, rice, coaloil, and cotton manufactures standing out as the favourites. Soap was the prime favourite when the Cayley tariff was enacted. The following year-1859 - when Galt amended the tariff of 1858, sugar was easily in the lead; and there was bestowed on a single refinery in Montreal, and continued to it until 1868, a largesse that was never equalled until after 1897, when the Laurier Government made the iron and steel industry its particular care.

Cayley's second and last term as InspectorGeneral came to an end on August 1, 1858 ; and on August 7 the first protectionist Inspector-General was succeeded by Galt, who has the distinction of having been the first Finance Minister, and who was the last Canadian Minister to whom protests were made from the Colonial Office in London against changes in the Canadian tariffs that were adverse to Great Britain. Trade was still depressed in the province in 1859, and there was no uplift until 1862, when the dislocation in industry in the United States due to the Civil War brought in an era of prosperity for Canada which continued until 1876. It is beyond question that additional revenue was needed in the winter of 1859 , when Galt introduced his memorable tariff. ${ }^{1}$ By this enactment

${ }^{1}$ It received the royal assent on March 26, 1859 ; 22 Vict. c. 2. 
CH.

duties at the rate of a hundred per cent were levied on brandy, gin, cordials, rum, and spirits. Such luxuries as soap, blacking, and starch, spices and dried fruits, and patent medicines were thrown into a class, containing seventeen items, paying duty at the rate of thirty per cent. Boots, shoes, harness, saddles, and wearing apparel were continued where Cayley had grouped them in 1858, at twenty-five per cent; and a new class, with duties at fifteen per cent, was created for books, maps, and printing-papers-obviously a concession to Buntin, a paper-maker at Toronto, who had been prominent in the St. Lawrence Hall Convention of $1858 .^{1}$

In the tariff of 1858 there was a class for iron and manufactures of iron, brass, and copper, in which the duties were five per cent. By the Galt tariff these duties were advanced to ten per cent. All articles not enumerated, including many lines of manufactures which Cayley had grouped in a twenty per cent class, were continued at this rate. The free list, which had been growing as the result of the reciprocity treaty, and of the policy adopted by Hincks in 1853 of admitting shipbuilding materials duty free, ${ }^{2}$ was extended by the tariff of 1859 until it included about a hundred and sixty items.

It was undoubtedly Galt's intention to extend the policy that Cayley had adopted in 1858-to increase import duties on manu-

1 Cf. Buchanan, p. 484.

${ }^{2}$ Cf. Globe, April 14, 1853. 
factures which were being produced in Canada, and to admit raw materials duty free. Only when he was in England did Galt ever deny that his tariff of 1859 was a protectionist measure. He told a meeting of the Chamber of Commerce, in Manchester, in 1862, that the object of the Canadian Government in 1859 "was to obtain the means of keeping. up the credit of the country, and was not intended, as had been stated, to introduce a protective system." He admitted that there were some items in the tariff of 1859 , not of very great importance, that bore a protectionist character; but urged that the best evidence that could be offered against a charge of protection was that the effect of the tariff had not been to encourage manufacturing in Canada. ${ }^{1}$

In Canada there was no doubt as to the policy of Galt's tariff of 1859. It was described by Sir Charles Tupper as a protectionist tariff in the National Policy debates at Ottawa in 1878, when Macdonald and the Conservatives were in opposition, and when they were insisting that more of Galt's policy was necessary to bring to an end the de-

1 Speech of A. T. Galt, at the Chamber of Commerce, Manchester.-Manchester Guardian, September 26, 1862. Galt must lave failed to keep himself well informed of industrial development in Canada; for eighteen months before his speech at Manchester, the New York Scottish American, a journal which in those days had a large circulation in Canada, had reported that several woollen mills were in operation in Ontario, and that joint-stock companies had been organised at Toronto, Dundas, and Sherbrooke -all in Ontario-for the establishment of cotton factories. $-N e w$ York Scottish American, April 7, 1860. 
pression in trade and commerce in the Dominion of Canada of 1877 and 1878. ${ }^{1}$

There could be no doubt as to the intent of the notorious sugar schedules in the tariff of 1859 ; for after the schedules had been amended in 1868, in the interest of sugar consumers and the revenue, the Mackenzic Government was criticised by the protectionists for not aiding what was then described as a declining Canadian industry. Sir C. Tupper voiced this complaint in the budget debates of 1878 , and was answered by Sir R. Cartwright, then Minister of Finance. "We refused," said Sir R. Cartwright, "to aid the great sugar interest of the country; that is to say, we refused to tax the people of Canada $\$ 400,000$ or $\$ 500,000$ or $\$ 600,000$ a year, as was done for a good many years under the tariff of Sir A. Galt, for the benefit of a single, no doubt deserving, but certainly sufficiently wealthy firm of manufacturers. If it be true that there were $\$ 400,000$ invested in this industry-which I do not doubt-all I can say is that during the tariff which prevailed for eight or nine years in Canada, these gentlemen received not cent per cent, but I strongly suspect seven or eight or nine hundred per cent on their investment. The honourable gentleman could not have given a better case in point. He could not have called attention more forcibly to the mischief which arises from regulating these

1 Cf. House of Commons Debates, February 22, 1878. 
tariffs for the benefit of a few individuals. I believe, although these gentlemen keep their business very close, that I am accurate in stating that under the operation of that tariff two or three millions of dollars-I have heard it put as high as five or six millions-were taken out of the pockets of the people of Canada, in order to make the fortunes of two or three wealthy gentlemen, as would be the case, not in the sugar industry alone, but in almost every other industry of a similar kind to which the same beneficient system of protection should be applied." 1

In the electoral campaign of 1878 the protectionists made much political capital out of the fact that at that time the refinery at Montreal was temporarily closed, and that three hundred workpeople, usually employed there, had had to seek work in the United States. "The Redpaths, who had made a large fortune by the business," said Mr. Oliver, an Ontario Liberal member, at a West Middlesex Liberal demonstration, "came to the Finance Minister, and told him that unless one cent a pound additional duty were put on refined sugar they would close their establishment. The Government refused to put such a tax upon the people, and by that refusal the people of Canada had been saved $\$ 1,120,000$. As Mr. Mills had stated in one of his speeches, if those three hundred workpeople at Redpaths were pensioned off by the Government

1 Cf. House of Commons Debates, February 15, 1878. 


\section{PROTECTION IN CANADA сн.}

at the rate of four hundred dollars each, the people of Canada would save a million dollars by the operation; for if the duty asked had been imposed it would have gone into the pockets of the Redpaths."

Sir R. Cartwright was at this Ontario demonstration in July 1878, and he made one of the speeches characteristic of him in the days before he and Sir W. Laurier went over to protection. "We may be mistaken," he then declared, "in the policy we advocate, in thinking that it is not for your interest to put taxes on you except for the purpose of clear general utility, or to redeem your credit; but at least we will abide by the policy we have announced." 1

Galt's tariff of 1859 , well remembered in Canada for its extraordinary largesse to the sugar-refining industry, is equally well remembered in England, and in all England's oversea possessions, for the controversy which it provoked with the Colonial Office; for as a result of the controversy of $1859-60$ colonies with responsible governments have ever since been free to levy what duties they deemed expedient on British imports, and for any reason judged by them sufficient, without interference from the British Government.

Sir Edmund Walker Head was GovernorGeneral in 1859, and the epoch-making correspondence between Canada and the Home Government began with a letter from Head

$$
1 \text { Globe, July 3, } 1878 .
$$


to the Colonial Office-March 29,-in which the Governor-General forwarded a copy of the new tariff. "It is to be regretted," he wrote in the accompanying letter, "that the necessity which exists for meeting the financial engagements of the province, and the depression of last year, have compelled the Government to propose rates of duty so high as these imposed by the present Act. I am aware of the objections which may be offered to the principle of ad valorem duties; but I must necessarily leave the representatives of the people in Parliament to adopt the mode of raising supplies which they believe to be most beneficial to their constituencies. There is nothing in the system adopted which proposes to impose differential duties or to fetter the freedom of trade."

Action in England on the new tariff appears to have been deliberate, probably owing to the fact that many of the new duties did not go into operation until the end of June. It was July before there were any protests from British manufacturers. Deputations from the Chamber of Commerce and manufacturers of Sheffield then waited on the Duke of Newcastle at the Colonial Office, and on August 1 a formal memorial from these Sheffield interests, many of them adversely affected by the increase in the duties, was submitted. In this memorial, which was signed by Charles Atkinson, Mayor of Sheffield, and Robert Jackson, Master Cutler, for John Jobson Smith, President of the 
Chamber of Commerce, the earlier deputation to Newcastle ${ }^{1}$ was recalled, and the memorialists restated the reasons which had led to their first complaint that the Galt tariff was adverse to Sheffield industries. "These reasons," the memorial continued, "may be said to be twofold: (1) those arising from a conviction that it is the deliberate policy of the Government of Canada to foster native manufactures by fiscal protection and every other means in their power; and (2) those arising from a consideration of the fact that there exists close to the Canadian border a body of competing United States mainufacturers, to whom such contiguity more than counterbalances the fact that they have to pay the same duties as ourselves."

"For proof that we are not mistaken about the policy of the Canadian Government," continued the memorial, "we would refer your" Grace to the tone of the whole press of Canada; to the speeches of members of the Canadian Parliament on both sides of the House; and especially to the steady increase of duties levied on Sheffield goods under every successive tariff. It will be sufficient to say on the last point that within eighteen years or less the duty levied on Sheffield goods has been steadily increased from two-and-a-half to twenty per cent. We would remind your Grace, in the second place, that while there is a protection in favour of Canadian manufac- 
turers against Sheffield of from thirty-five to forty per cent-consisting of land carriage, freight, insurance, commission, shipping expenses, and duty - that, owing to the close contiguity of and cheap transport from the competing seats of American industry, similar goods can be sent across the Canadian frontier by United States manufacturers at a cost of from twenty-two-and-a-half to twenty-five per cent. It is therefore plain that the American manufacturer has actually an advantage over the Sheffield manufacturer of from twelveand-a-half to fifteen per cent. As this is a natural protection, however, and consequently one that remains about the same, be the Canadian duty what it may, we only name it to show your Grace how great the obstacles are naturally against which Sheffield has to struggle, and for the purpose of remarking, as another objection to any increase of duty, that it is actually the interest of American manufacturers that the duty should be raised, since any hindrance or confusion caused to Sheffield manufacturers can only tend to divert the demand towards markets easier of access, and with which intercourse is more quickly exchanged than with Sheffield. It is important, too, to remember that the American manufacturer has more than one thousand miles of frontier over which he can smuggle with impunity."

"The merchants and manufacturers of Sheffield," reads the concluding paragraph in 


\section{PROTECTION IN CANADA сн.}

the memorial of August 1859, "have no wish to obtain special exception for themselves, and do not complain that they are called upon to pay the same duty as the American or the German. Neither do they desire to have their goods admitted free of duty. All they ask is that the policy of protection to native manufacturers in Canada should be distinctly discountenanced by Her Majesty's Government as a system condemned by reason and experience; directly contrary to the policy solemnly adopted by the Mother-country, and calculated to breed disunion and distrust between Great Britain and her colonies. It cannot be regarded as less than indecent and a reproach, that while for fifteen years the Government, the greatest statesmen, and the press of this country have been not only advocating but practising the principle of free trade, the goverument of one of Great Britain's most important colonies should have been advocating monopoly and protection. Under the artificial stimulus of this system extensive and numerous hardware manufacturers have sprung up both in Canada East and West; and the adoption of increasing duties has been the signal for more to be commenced."

The Sheffield memorial was transmitted by Newcastle to the Governor-General, with a request that he would lay it before his executive council, and observe to that bodythe cabinet of the province-that he could 
not but feel that there was much force in the argument of the Sheffield manufacturers. "Practically," continued Newcastle in this letter of August 13 to Head, "this heavy duty operates differentially in favour of the United States in consequence of the facility for smuggling which so long a line of frontier affords, and the temptation to embark in it which a duty of twenty per cent offers. Regarded as a fiscal expedient the measure is impolitic; for while any increase of contraband trade must be at the expense of the exchequer, the diminution of foreign importations will probably more than neutralise the additional revenue derived from the higher duty. Whenever the authenticated Act of the Canadian Parliament on this subject arrives, I may probably feel that I can take no other course than signify to you the Queen's assent to it, notwithstanding the objections raised against the law in this country. But I consider it my duty, no less to the colony than to the Mother-country, to express my regret that the experience of England, which has fully proved the injurious effect of the protective system and the advantage of low duties upon manufacturers, both as regards trade and revenue, should be lost sight of, and that such an Act as the present should have been passed." "I much fear," Newcastle added, "the effect of the law will be that the greater part of the new duty will be paid to the Canadian producer by the colonial consumer, 
whose interests, as it seems to me, have not been sufficiently considered on this occasion."

Galt replied to Newcastle's letter and to the Sheffield memorialists on October 25, from the city of Quebec. He first expressed his regret that the Secretary for the Colonies had endorsed the statements of the Sheffield manufacturers, and then set out at length what he held to be the position and rights of the Canadian Parliament in the question at issue. "It is deeply to be regretted," he wrote in the memorandum which he drew up for transmission to London by the Governor-General, " that His Grace should have given to so great a degree the weight of his sanction to the statements in the memorial without having previously afforded the Government of Canada the opportunity of explaining the fiscal policy of the province and the grounds upon which it rests. The representations upon which His Grace appears to have formed his opinions are those of a provincial town in England, professedly actuated by selfish motives; and it may fairly be claimed for Canada that the deliberate acts of the Legislature, representing nearly three millions of people, should not have been condemned by the Imperial Government on such authority until the fullest opportunity of explanation had been afforded. It is believed that nothing in the legislation of Canada warrants the expressions of disapproval which are contained in the despatch of His Grace, but that, on the contrary, due 
regard has been had to the welfare and prosperity of Her Majesty's Canadian suljjects."

"Respect to the Imperial Government," continued Galt, in stating what he held to be the rights of the Colonial Government, " must always dictate the desire to satisfy them that the policy of this country is neither hastily nor unwisely formed, and that due regard is had to the interests of the Mother-country as well as of the Province. But the Government of Canada, acting for its Legislature and people, cannot through those feelings of deference which they owe to the Imperial authorities, in any measure waive or diminish the right of the people of Canada to decide for themselves both as to the mode and extent to which taxation shall be imposed. The Provincial Ministry are at all times ready to afford explanations in regard to acts of the Legislature to which they are party; but subject to their duty and allegiance to $\mathrm{Her}$ Majesty, their responsibility in all general questions of policy must be to the Provincial Parliament, by whose confidence they administer the affairs of the country. And in the imposition of taxation it is so plainly necessary that the administration and the people be in accord, that the former cannot admit responsibility or require approval beyond that of the local Legislature. Selfgovernment would be utterly annihilated if the views of the Imperial Government were to be preferred to those of the people of 
Canada. It is, therefore, the duty of the present Government distinctly to affirm the right of the Canadian Legislature to adjust the taxation of the people in the way they deem best-even if it should unfortunately happen to meet with the disapproval of the Imperial Ministry. Her Majesty cannot be advised to disallow such Acts unless her advisers are prepared to assume the administration of the affairs of the colony, irrespective of the views of its inhabitants."

"The Imperial Government," continued Galt, "are not responsible for the debts and engagements of Canada. They do not maintain its judicial, educational, or civil service. They contribute nothing to the internal government of the country; and the Provincial Legislature, acting through a ministry directly responsible to it, has to make provision for all these wants. They must necessarily claim and exercise the widest latitude as to the nature and extent of the burdens to be placed upon the industry of the people. The Provincial Government believes that His Grace must share their own conviction on this important subject; but as serious evils would have resulted had His Grace taken a different course, it is wiser to prevent future complications by distinctly stating the position that must be maintained by every Canadian administration."

Galt admitted that there existed in Canada "a large and influential party which advocated a protective policy"; "but this policy," he 
continued, "has not been adopted by either the Government or Legislature, although the necessity of increased taxation for the purposes of revenue has to a certain extent compelled action in partial unison with their views, and has caused more attention to be given to the proper adjustment of the duties, so as neither unduly to stimulate nor depress the few branches of manufacture which exist in Canada. The policy of the present Government in readjusting the tariff has been, in the first place, to obtain sufficient revenue for the public wants; and secondly, to do so in such a manner as would most fairly distribute the additional burdens upon the different elasses of the community; and it will undoubtedly be a subject of gratification to the Government if they find that the duties absolutely required to meet their engagements should incidentally benefit and encourage the production in the country of many of those articles which we now import."

"The Government," continued Galt, in enlarging on this phase of its policy, "have no expectation that the moderate duties imposed by Canada can produce any considerable development of manufacturing industry. The utmost that is likely to arise is the establishment of works requiring comparatively unskilled labour, or of those competing with American makers for the production of goods which may equally well be made in Canada, and which a duty of twenty per cent will no 
252 PROTECTION IN CANADA сн.

doubt stimulate. That these results should flow from the necessity of increased taxation is no subject of regret to the Canadian Government; nor can it be alleged as any departure on their part from the recognised sound principles of trade."

It was in this correspondence of AugustOctober 1859, that Galt made the statement as to the device which had been adopted by the Canadian Government to divert Canadian trade from the United States to Great Britain - the statement which was used with so much effect in Congress at Washington between 1861 and 1865, when the reciprocity treaty was assailed. "The Chamber of Commerce at Sheffield," he informed Newcastle, "evidently is quite ignorant of the principle upon which the valuation of goods for duty is made in Canada-which is on the value in the market where bought. The sheffield goods are, therefore, admitted for duty at their price in Sheffield, while the American goods are taken at their value in the United States. This mode of valuation is clearly in favour of the British manufacturer; and is adopted with the deliberate intention of encouraging the direct trade." 1

Another statement by Galt has even more significance to-day than it had in 1859 . "There are," he said, in reference to the apprehensions of the manufacturers of Sheffield

1 This method of valuing imports for duty was continued until 1866. Cf. $29 \& 30$ Vict. c. 7 . 
that the United States would capture trade which had hitherto gone to Sheffield, " certain descriptions of hardware and cutlery which are manufactured in a superior manner by the American and Canadian manufacturers; and these will not under any circumstances be imported from Sheffield." The present-day significance of this frank statement lies in the similarity of the needs of the people of the United States and Canada - a similarity which is due to climate and to many conditions of work-a-day life. In most lines of industry, tools and equipment and materials serve equally in Canada and the United States. Hence the fact that in spite of the tariff preference for British imports American export trade to the Dominion increases more rapidly than the export trade from Great Britain.

Between Newcastle's letter of August 13 and Galt's reply of October 25, the new tariff had been reported on to the Colonial Office by officials of the Committee of Privy Council for Trade-the committee which at this time discharged many of the duties now undertaken by the Board of Trade at Whitehall. "The tariff," reads this report of October 20, "contains modifications of the one established by the Act of 1858, the most striking feature of which is the extension of ad valorem duties to articles which under the latter Act were charged specific and rated duties. The Act is, however, still open to the principal objection to which the former Act is liable, viz. the 


\section{PROTECTION IN CANADA сн.}

augmentation of the duties upon all the most important articles of manufacture from fifteen per cent, which was the rate of duty charged upon them prior to 1858 , to twenty per cent and twenty-five per cent. Among the articles liable under the present tariff to twenty per cent ad valorem are all the leading textile fabrics, such as cottons, linens, woollens, and silks; as well as iron and hardware, earthenware, and unmanufactured leather; while manufactures of leather, viz. harness and saddlery, boots and shoes, are charged with twenty-five per cent."

"Of all these articles," continued the report, " the colony has hitherto drawn the principal supply from the United Kingdom. It is unnecessary to remark that the increased burden thus placed upon a trade of so much importance cannot fail to be severely felt by the exporters of the United Kingdom, as well as by the consumers in the colony; and cannot but be regarded by My Lords with much regret. This regret is increased by the reflection that, owing to the facilities afforded by the extensive inland frontier of Canada for contraband trade, the present measure has a direct tendency to encourage the competition of the United States manufacturers in the Canadian markets; while by the protection which will at the same time be afforded to the manufacturers of the province, it will favour the interests of a very small class at the expense of the body of the population." 
It was not suggested by the Committee of Privy Council for Trade that the sanction of the Home Government should be withheld. The statement of the Governor-General as to the need for revenue was recalled in the report; and in its concluding paragraph the opinion was expressed that, "in leaving the Act to its operation Her Majesty's Ministers should express their regret that the fiscal requirements of Canada should have compelled it to resort to a measure so objectionable in principle, and their apprehension of the injurious effect which it is calculated to produce on the industrial progress of the province."

Galt's memorandum of October 25 was submitted by the Colonial Office to the Committee of Privy Council for Trade. James Booth, who was then statistician to the committee, reported on it on January 17, 1860. "My Lords," wrote Booth, "do not perceive anything in Mr. Galt's explanation of the recent Canadian tariff to affect the conclusions at which they arrived from an examination of the tariff, which were communicated to the Colonial Office, October 20, 1859. They cannot, however, lose sight of the fact that under the present tariff the rates of duty levied upon quite two-thirds of the duty-paying imports into Canada have been raised since 1856 from twelve-'and-ahalf to twenty per cent, being an increase of sixty per cent; and that this increased burden has ever since that date been placed upon the 
CH.

principal manufactures exported from the United Kingdom to Canada. My Lords, therefore, cannot but regret the fiscal necessities which have compelled this most important colony to adopt a policy, the tendency of which, whatever its immediate effect may have been, is unquestionably to check the natural development of her foreign trade and impair her industrial progress."

"Mr. Galt," continued Booth's report, "disclaims on the part of the Government of Canada any intention of offering by means of a tariff of increased duties upon foreign manufactures an artificial stimulus to the industry of the province; and My Lords are glad to find that such an object formed no part of the intention of that Government in readjusting their customs system. They cannot, however, concur with Mr. Galt in thinking that it should be a subject of gratification to the Canadian Government if it is found that the duties absolutely required to enable them to meet the engagements of the province should incidentally benefit and encourage the production at home of many articles which they now import. On the contrary, My Lords are of opinion that should this incidental effect be produced by the operation of the present tariff, and branches of native industry be created which could not equally have prospered without protective duties, it may be found when the financial condition of the province might enable the 
Government to reduce their import duties, that a class of interests will have grown up which will impose a very serious obstacle in the way of a return to a sounder commercial policy, and that a system of taxation adopted for the legitimate object of revenue may be continued for the mischievous purpose of protection."

This second report from the Committee of Privy Council for Trade was also transmitted to Quebec. "It appears to the Minister of Finance," wrote Galt, in commenting in particular on the paragraph in which Booth, with such remarkable prescience, predicted that the protected manufacturers would be careful that duties were never again on a revenue basis, "that My Lords object to a result which in the first instance must necessarily be advantageous to the country, from a vague apprehension that in the uncertain future it may prevent a diminution of duties on manufactures. In any country it would seem desirable to vary the employment of capital and industry, and to diminish, if not altogether prevent, the disasters which attend a failure in the case of a people depending altogether on one means of subsistence."

It does not seem to have occurred to Galt that the day would ever come in Canada when protectionists would abandon the infant industry plea and substitute for it pleas such as were advanced with success before the Tariff 
Commission of 1905-6, that protection should be continued and duties increased in order to enable Canadian manufacturers to specialise; to build up an export trade; or that the whole of the Canadian market should be reserved by legislation for Canadian manufacturers. "The first establishment of even the lower grades of manufactures," Galt urged in his answer of March 13, 1860, to the report of the Committee of Privy Council for Trade of January 17, "is always attended with difficulty; and investments of this nature, when once in operation, and having secured the skilled labour required, will be able to maintain themselves even in the face of a gradual future reduction of duty. It may also be observed that if the coarser articles be manufactured in any country the larger ability will it possess to import those of a more expensive character. A large part of Canada is not capable of producing a surplus of cereals for export; and it ought, therefore, to be a subject for congratulation if, without imposing any duty for the purpose of protection, employment can be found for those labouring classes who now seek it in the United States." 1

As foreshadowed in Newcastle's letter of August 13, 1859, to the Governor-General, the royal assent was given to the new tariff

1 Cf. Correspondence of the Government of Canada with the Imperial Government on the subject of the Canadian tariffprinted as a Canadian Parliamentary Paper, 1860. 
in the form in which it was enacted. Galt's policy was triumphant; and in the session of 1860, when the Finance Minister submitted the correspondence to the Legislature, he announced that he was gratified to add that when the papers were read by members of the House, it would be found that on the point on which the British Government objected to the tariff they had been obliged to admit that "we were in the right, and that any assumed interference with our rights and privileges is not for one moment to be entertained." 1

It is probable that Galt expected that he would come into conflict with the Home Government over the tariff of 1859. This can be inferred from the speech in which he introduced his bill to the Legislature, on March 14, 1859, when he explained the fiscal policy to which he was about to commit the province. "The policy pursued with regard to taxation in this country," he then said, "has been objected to in England. But I am perfectly certain that this House will never permit any other body to interfere with its proper right to determine what shall be the amount and mode in which taxes shall be put upon the people. Canada has adopted the protective policy; and it is scarcely fair for parties in England to criticise our policy, when in point of fact the greater part of our

${ }^{1}$ Cf. Larned, Report on Reciprocity, Executive Documents (Washington), 1870-71, p. 30. 
debt was incurred when they had a protective policy in England." 1

Even Galt's admirers cannot claim that he was always sincere in his statements regarding the character of his tariff of 1859 . 'To Newcastle he denied that the Government of Canada had adopted a protective policy. $\mathrm{He}$ repeated this assertion when he addressed the Chamber of Commerce at Manchester in 1862, and in 1859 , when he sent to the Colonial Office a copy of the report of his speech in the House in introducing the tariff, he withheld the paragraph which has just been quoted. At all events, that paragraph does not appear in the correspondence as officially published, although it formed part of the Globe report of the debate in the House of Assembly of March 14, 1859. ${ }^{2}$

Between Galt's tariff of 1859 and 1876, when the Conservatives, then in opposition at Ottawa, adopted avowedly and completely the National Policy that Cayley and Galt had inaugurated, the protectionist movement in

1 Globe, March 14, 1859.

2 In connection with this last protest of the British Government against tariff legislation in Canada, it may be noted that as late as 1850 Crampton, the British Minister at Washington, acting on instructions from Downing Street, made an appeal to the United States Goverument to use its influence with Congress to prevent a pending increase in the duties on iron. Crampton urged that the existing duties weighed heavily on British productions; " and I cannot but observe, for my own part," he added, "that an augmentation of the duties on British products or manufactures, made at a moment when the British Government has by a series of measures been facilitating commerce between the two countries, would produce a very disagreeable effect on public opinion in England."-Appendix to Congressional Globe, May 15, 1850. 
the provinces of Ontario and Quebec made comparatively little headway. Buchanan, as a member of Parliament, and as a journalist and pamphleteer, was active until as late as 1863. ${ }^{1}$ In 1864 a duty as high as fifteen cents a gallon was imposed on illuminating oils in the interest of refineries in Ontario. ${ }^{2}$ In 1866 there were meetings in Toronto and Montreal in support of the home industries movement, seemingly a continuation of the propaganda of the Association for the Promotion of Canadian Industry. ${ }^{3}$ In 1868 John MacLean published his pamphlet on protection and free trade, from which is sometimes dated the beginning of protection in Canada, ${ }^{4}$ and in 1870 the first legislative step after Confederation in the direction in which Canada had been started by Cayley and Galt was taken, when the Macdonald Government imposed a duty of fifty cents a ton on coal, exclusively in the interest of the mining industry of Nova Scotia, and with the intention of forcing the Government of the United States to reduce the duties which since the end of the reciprocity treaty in $1866 \mathrm{had}$ been imposed on coal from the Maritime Provinces.

There are several obvious reasons why the

1 Cf. Buchanan, The Relations of the Industry of Canada with the Mother Country and the United States, p. 229.

2 Cf. 27-28 Vict. c. 2.

${ }^{3}$ John MacLean, Protection and Free Trade, Montreal, 1868, pl. 3 and 4.

4 Cf. Morgan, Canadian Men anil Women, p. 707. 
protectionist movement between 1860 and 1870 did little more than mark time. In these ten years other political questionschief among them Confederation of the British North American colonies - were engaging public attention. In this decade also Canada was extremely eager for a renewal of the reciprocity treaty of 1854-66; and it would have been impolitic to advance duties beyond the point at which they stood in the Galt tariff of 1859. One of the strongest arguments at Washington for the abrogation of the Elgin-Marcy Treaty was the increase of duties in the Canadian tariffs of 1856,1858 , and 1859-the increase of which the manufacturers of Sheffield had complained to the Colonial Office in 1859. Even protectionists like Buchanan attached enormous importance to a reciprocity treaty; and it would have been futile to hope for a renewal of the treaty abrogated in 1866, had there been any increase in the duties in the Canadian tariff.

The movement for Confederation had an even stronger influence in halting the protectionist movement in Ontario and Quebec. At an early stage in the negotiations that preceded Confederation the Maritime Provinces had made it plain that one of the obstacles to their coming into Confederation was the great difference between the tariff of the United Provinces and the tariffs of Nova Scotia, New Brunswick, and Prince Edward Island, which were all low-none of them 
with duties exceeding twelve-and-a-half per cent-all on a revenue basis, and entirely free from protectionist schedules. ${ }^{1}$ The negotiations for Confederation not only checked the National Policy movement, they were directly responsible for the tariff of $1866,{ }^{2}$ the last tariff enacted by the Legislature of the United Provinces-in which the general range of duties was put back to fifteen per cent-the level at which they had stood prior to the protectionist changes made by the Cayley tariff in $1858 .^{3}$

So ae protective duties were continued by the tariff of 1866-notably in the case of sugar, soap, and illuminating oils-but generally the tariff was for revenue only. The coal duty, enacted in 1870 , was repealed in 1871. It was not reimposed until 1879 ; and it was the needs of the Government, and not the exigencies of a protective policy, that impelled the Mackenzie administration in 1874 to advance duties from fifteen to seventeenand-a-half per cent. Sir R. Cartwright was Minister of Finance in 1874. The administration of 1874-78 was the only one in which he held that office; for when the Liberals, after eighteen years of opposition, were again returned to power in $1896, \mathrm{Mr}$. Fielding of Nova Scotia became Minister of Finance; and to Sir R. Cartwright, who until 1897 was

1 Cf. Simon J. McLean, The Tariff History of Canada, p. 10. 2 29-30 Vict. c. 7.

3 Cf. Cartwright, House of Commons Debates, April 15, 1890. 
the foremost advocate of free trade in the Dominion, belongs the distinction of having been the last Finance Minister of Canada to introduce a tariff for revenue only, and the last member of a Liberal administration to defend from the Treasury Bench of the House of Commons the principles of free trade. 


\section{CHAPTER IX}

THE NATIONAL POLICY AS A MEASURE OF RETALIATION-1870 TO 1874

THE protectionists loudly profess loyalty, which with them means high duties on American goods. International hatred, directed in Canada against her American neighbours, and political corruption are two inseparable companions of the system.-GoudwiN SMiтh.

They have known how to clothe self-seeking in the fine garments of love of country, and to make a vast system of social demoralisation and political corruption wear an altruistic appearance. Their phrases have deceived the people, and enriched the beneficiaries of the tariff.-New York Evening Post.

THE barbarous instinct of the protectionist mind.Sir Richard Cartwright.

The history of protection in Canada falls into two well-marked divisions. The National Policy of the United Provinces, associated with Cayley and Galt, and with the tariffs of 1858 and 1859, forms the first; and the National Policy of the Dominion of Canada-the policy associated with Sir J. A. Macdonald, Sir Leonard Tilley, and Mr. Foster, and since 1897 with Sir Wilfrid Laurier and Mr. Fielding, 
CH.

with duties as high as thirty-five and forty per cent, lavish bounties, and the influence in politics of the Red Parlour and the Canadian Manufacturers' Association-forms the second of these divisions.

The National Policy of Macdonald admits of a somewhat similar division. Macdonald's name is usually associated only with the protective tariffs and the bounty enactments that were on the statute books from 1879 to 1897 . This is the Conservative National Policy era that began after Macdonald's rehabilitation following his downfall in 1873 due to the Canadian Pacific Railway scandal. There was, however, an earlier era of Conservative National Policy; for as soon after Confederation as 1870, Macdonald and the Conservatives, who were in power from 1867 to 1874 , attempted to put into operation a National Policy. It was tried for a year and abandoned, because in 1871 Conservatives in the House of Commons, who usually followed Macdonald's lead, joined forces with the Liberals under Mackenzie, and compelled the Government to repeal duties on coal and cereals which had been imposed by the tariff of 1870 .

In the debates of 1870 , in which Macdonald made it clear that he had no sympathy with free trade as it was understood in England, ${ }^{1}$ both Macdonald and Sir Charles Tupper described the policy which the Government was pressing

1 Cf. Macdonald's reply to Holton, House of Commons Debates, April 26, 1870. 
on the House of Commons as a National Policy. But the legislation of 1870 was rather retaliatory than protectionist. It was, as Macdonald afterwards described it, an assertion of the independence of Canada against the exclusive legislation of the United States. ${ }^{1}$ Neither the National Policy League nor the Canadian Manufacturers' Association was in existence in 1870. Had the Manufacturers' Association then been organised and active in its propaganda, only indirectly could the tariff legislation of 1870 have afforded it any satisfaction. Duties in the manufacturing schedules were not increased. They stood at fifteen per cent as imposed by the tariff of 1866 , which was framed with a view to easing the way of the Maritime Provinces into Confederation. Duties were not increased in the tariff of 1870 ,- the first National Policy tariff after Confederation; but new duties were imposed on coal, salt, flour, meal, wheat, and hops. All these articles had hitherto been on the free list. They were made dutiable in accordance with the theory of the Macdonald Government that if Canada was ever to succeed in negotiating a second reciprocity treaty with the United States, the Government at Washington must be made to feel that it was in the power of the Government at Ottawa to harass American trade with Canada.

The only coal mines in the Dominion in 1870 were those in Nova Scotia. From 1854

1 Cf. House of Commons Debates, Mareh 8, 1878. 
to 1866 , while the Elgin-Marcy Treaty was in force, there had been a large and increasing trade in coal between Pictou and Sidney and Portland, Boston, Providence, New Haven, and other New England coast cities. In 1866, when the treaty was abrogated, Nova Scotia mining companies found themselves confronted with a duty of a dollar and a quarter a ton on coal at the New England ports. Trade fell off. There was much less work for the two or three thousand men employed at the mines, and less employment for Maritime Province shipping. ${ }^{1}$

'The import duty on coal and coke in the Canadian tariff of 1870 was fifty cents a ton. It was imposed with the object of compelling the United States Government to repeal its duty on coal ; and failing this, of forcing Nova Scotia coal into use, not only in Quebec and Montreal, but as far west as Toronto and Hamilton, eities which naturally draw their coal supplies from Pemnsylvania. It had been one of the aims of the National Policy of 1858-59 to divert trade from its natural channels; to compel merchants in Montreal and Toronto to cease importing viâ Boston and New York, and use exclusively the St. Lawrence route. The coal duty in the tariff of 1870 was the first effort of the Dominion Government similarly to alter the natural course of trade $;^{2}$ and to this end the duty of

1 Cf. Lawrence Oliphant, Episodes in a Life of Adventure, p. 64.

${ }^{2}$ Cf. Jlorgan, Dominion Annual Register, 1880-81, p. 59. 
fifty cents a ton was imposed alike on anthracite and bituminous coal, although in 1870 no anthracite was mined in Canada.

The tariff of 1870 , with this duty on coal, was enacted by the Conservative party-the party in Canada which for seventy years has displayed the most effusive loyalty to England -at times insistently claiming a monopoly of loyalty to Great Britain. ${ }^{1}$ It is significant of the slight value that attaches to these wavings of the old flag whenever trade interests or the exigencies of party politics at Ottawa are at stake, that it was in this National Policy tariff of 1870 that British trade and shipping received their first serious blow from a Dominion Government. At this time British steamers and sailing vessels coming to Quebec and Montreal for lumber and other Canadian produce often carried coal as ballast. This coal was retailed in Quebec and Montreal at from twelve to thirteen shillings a ton. It was largely used for domestic and manufacturing. purposes; and most of the river steamers at the St. Lawrence ports also used this British coal for bunkering. Little of it went farther inland than Montreal. It was a trade that was advantageous in every way ; for it resulted in comparatively cheap coal for Montreal and Quebec, and it tended to cheapen eastward trans-Atlantic freights. In the year previous to the enactment of the duty, 159,000 tons of British coal were landed at the St. Lawrence

\footnotetext{
${ }^{1}$ Cf. House of Commons Debates, March 18, 1879.
} 
ports, and 26,000 tons at St. John and other New Brunswick ports at which British vessels loaded deals and other lumber. ${ }^{1}$

A duty of five cents per bushel of fifty-six pounds was imposed in this tariff on salt. It was one of the retaliatory duties against the United States, and was aimed at the salt industry at Syracuse and Salena, in the State of New York. There was, however, a provision in this case that the duty was not to be imposed on salt from Great Britain-the first instance since Canada secured her fiscal independence in 1846 of a direct preference in a Canadian tariff for British imports, and the only instance of such a preference until the enactment of the Fielding tariff in 1897. But there was no such provision in regard to coal-no such safeguard for the long-established British trade with the St. Lawrence ports and St. John; and British coal paid the duty until it was repealed in $1871 .^{2}$

Macdonald's National Policy tariff of 1870 has another noteworthy feature. It was the first enactment of the Dominion Parliament intended to afford protection to agriculture. The principal object of the duty of twentyfive cents a barrel on flour and of the duties on cereals was to make the United States understand that Canada could retaliate if there was to be no reciprocity treaty. ${ }^{3}$ A second

1 Cf. House of Commons Debates, April 27, 1870.

2 Cf. 33 Vict. c. 9 and 34 Vict. c. 10.

3 "These duties, which leave a now quite insignificant free list of commodities, so far as American trade is concerned, were avowedly 
object was to furnish return cargo for the vessels that came to Quebec and Montreal with Nova Scotia coal, and to compel the Maritime Provinces to make some return to Ontario for the duty on coal in the interest of Sydney and Pictou. A third and most hopeless object was to persuade the farmers of Quebec and Ontario that it was possible to afford them protection by National Policy tariffs.

As a retaliatory measure the Act of 1870 was a failure. Due notice was taken at Washington that the Act was intended to be retaliatory; and there, so far as reciprocity was concerned, the matter ended. From the first the new duties were of service only to the flour millers of Ontario and the coal companies of Nova Scotia. Eleven years later, when the National Policy of 1879 was in full working, and when the duty on coal, which had been repealed in 1871, had been reimposed, the coal operators of Sydney and Pictou, protectionist-like, clamoured for higher duties. These were conceded. The duty was increased from fifty cents a ton to sixty cents. All pretence that the duty would compel the

levied in retaliation for the protective rigour of the United States tariff; and by the Act which imposes them the Governor in Council is authorised to suspend or modify them by proclamation, together with the duties on fish, meats, butter, eheese, lard, tallow, vegetables, and several other articles, 'whenever it appears to his satisfaction that similar articles from Canada may be imported into the United States free of duty or at a rate of duty not exceeding that payable on the same when imported into Canada.' "-Larned, State of Trade with British North American Provinces, Executive Documents, No. 94, Third Session, 41st Congress, p. 9. 
United States to concede a new reciprocity treaty had long been abandoned; and Tilley, who was then Minister of Finance, admitted that even in 1881 the duty had not achieved its second purpose-that of forcing Nova Scotia coal into cities as far west as Hamilton. There is still a duty on bituminous coal. It is now sixty cents a ton, as fixed by the Fielding tariff of 1897 , less the preference on coal imported from Great Britain. But after thirty years of this effort to divert trade from its normal channels-an effort that has been persisted in by Liberal as well as Conservative Governments-it has been impracticable to make a market for Nova Scotia coal west of Prescott, Ontario; and most of the Nova Scotia coal that now comes to Quebec and Montreal-in steamers that are compelled to go back to Sydney and Pictou in ballast; for there is no cargo-offering at the St. Lawrence ports for Nova Scotia-goes no farther west than the Island of Montreal.

To-day there is a community of interest between the protected manufacturers of Ontario and Quebec and the four or five great companies that control coal-mining in Nova Scotia and Manitoba and British Columbia. There is an understanding, or gentlemen's agreement, as such compacts are termed in the phraseology of trusts and combinations, that these two interests-manufacturing and coal-miningshall support each other when the tariff is being revised or when protection is assailed, 
and that both shall levy full statutory toll on the consumer. There was obviously an understanding between these interests in 1905-1906 that the coal duties should not be assailed. Only when the Tariff Commission was at London and at Sault Ste Marie was the duty on coal objected to by manufacturers. It was nowhere assailed by the Manufacturers' Association; and in some instances when members of the Tariff Commission sought the opinion of manufacturers as to the coal duty the answer was, "We have nothing to say on that question"; although many of the manufacturers supported their pleas for increased protection on the ground that they were compelled to pay duty on their coal.

There was no such community of interest between the manufacturers and the coal companies in 1870 ; and at that time the coal companies had no such support in the newspaper press as they have had since 1897 in the Government organs of Toronto, Montreal, Halifax, and St. John. Coal company promoters and directors in 1870 were not quite so close to the politicians at Ottawa as they are to-day. None of these men was then of the Senate; and in those days they had not yet realised the hold they could have on politicians in power by controlling the principal newspapers that support the Government. In 1870 the duty on coal was vigorously assailed by the manufacturers and the gas companies. Nembers of the House of Commons from New 
Brunswick bitterly complained that that province, which could derive no advantage from the tariff, was severely hit by the new duties on coal and flour, and that pledges as to the tariff which had been given at Confederation were violated: A protective tariff was a new experience to the people of New Brunswick. All the tariffs enacted by the Legislature at Fredericton, prior to Confederation, had been for revenue only; and the people of New Brunswick were most unwilling to see the taxing powers of the Government at Ottawa -a government with which at this time they were little acquainted, and of which they were not much enamoured-delegated to the coal operators of Nova Scotia and the millers of Ontario, to be used for their own enrichment.

Macdonald could not persuade New Brunswick of the importance of thinking Imperially. He was no more successful in his effort to arouse a Dominion sentiment in Ontario than he was in New Brunswick. Coal and flour bills in New Brunswick, and the winter's coal bills in Ontario after this "broadening of the basis of taxation," took on a political significance; and the upshot of a year's agitation was that in 1871 Maedonald's National Policy encountered its first defeat in Parliament, and the retaliatory duties of 1870 were repealed. ${ }^{1}$ They disappeared, as was remarked in a tariff debate in 1878 , without a squeak or a groan.

In 1870, when Macdonald was urging a

2 Cf. 34 Vict. c. 10. 
National Policy in the House of Commons, while he was contemptuous in his allusions to free trade and its advocates in England, he had no clear idea of the scope of the protectionist policy to which he would commit Canada. Mackenzie, the leader of the Opposition, pressed him as to what was the National Policy he was advocating. "We must," was Macdonald's only answer, "have a Canadian policy" ; and Macdonald's conception of a Canadian policy was embodied in the shortlived retaliatory tariff of 1870 . This policy was defeated while Macdonald was away in Washington in 1871 ; and from this defeat it is possible to date when he began to regard it as expedient from a party point of view to go beyond mere retaliation; for early in 1872, when looking ahead to the general election that came in July, he wrote to one of his political lieutenants that at the hustings in Western Canada, and in all the constituencies except Toronto, the battle would be between free trade and a National Policy. "The farmers," he added, "are indignant at the Opposition having taken the duty off American cereals last session; and they all say, and say truly, that if I had been here instead of at Washington, it could not have occurred. It is really astonishing the feeling that has grown up in the west in favour of the encouragement of home manufactures." 2

1 Cf. House of Commons Delates, April 26, 1870.

${ }^{2}$ Cf. Pope, Life of Sir John Macdonald, ii. p. 289. 
During the election in 1872 Macdonald announced at Hamilton that it was the policy of the Conservative Government to afford by the tariff incidental protection to Canadian industries. $\mathrm{He}$ said he knew that any such policy would meet with the hostility of the Liberals, who were heart and soul in favour of free trade; and for that reason he urged on the electors of Hamilton the desirability of defeating the Liberal candidates for that eity. But the question of free trade or protection was not to the front in this election; and in 1873, when Tilley introduced the budget, he announced that the Government did not intend to touch the tariff in any particular. ${ }^{1}$

Macdonald's majority at the general election in July 1872 was only six. In the ordinary course of events he would soon have been compelled to go again to the constituencies. But the session of 1873 was by no means an ordinary one. It developed the grossest political scandal in the modern history of British Parliaments. In his overeagerness to amass an immense eampaign fund, Macdonald had accepted, in association with two of his ministerial colleagues, two hundred thousand dollars from Sir Hugh Allan. Allan had also put, on his own account, a hundred and sixty thousand dollars "where it would do most good" in securing the election of supporters of Macdonald. In

1 Cf. House of Commons Debates, March 8, 1878. 
return for these enormous outlays in the interest of the Conservatives at the general election in July 1872, Allan was granted on February 8, 1873, a charter for the Canadian Pacific Railway. Allan's position was virtually that of a contractor for the railway.

This squalid transaction, sordid and squalid in spite of its magnitude, was first brought to the attention of the House of Commons in April. 'The full story, with the letters and telegrams which had passed between the principals, was told in the newspapers of July 1. At the investigation by Royal Commission in August, Allan stated that he cared nothing for either of the political parties struggling for mastery at Ottawa; but he thought that Macdonald and Cartier, the leader of the French Conservative group in the House of Commons, were men he could deal with. $\mathrm{He}$ accordingly courted them assiduously, and made a handsome contribution to the Conservative election fund. It was pleaded for Macdonald and his incriminated colleagues that the money received from Allan did not go to them personally; that it was a contribution to party funds; and that there was nothing wrong in the charter. That there was nothing wrong with the charter was true, but it was evident that, when its foremost members had taken Allan's money, the Government would be in his hands. 
Public indignation was aroused in Canada as it has never been before or since. The newspapers-Canadian, British, and American - were full of the scandal. Questions were asked in Parliament at Westminster; for the British Government had guaranteed the loan of eighteen million dollars to the Dominion Government, out of which the railway was to be built. "These charges, affecting at least some members of the Government of Canada," Gladstone answered in the House of Commons, " are very decidedly within the power of the Legislature of the Dominion. The Canadian ministers are responsible to their Parliament, and are not responsible in any way to us for their conduct."

The revelations of the Royal Commission were made during the recess. The Dominion Parliament did not meet until October 23, 1873. The scandal was discussed for seven days in the debate on the address. Macdonald resigned before Mackenzie's motion of censure was voted upon, and on November 7 Mackenzie became Premier, with Sir R. Cartwright as Minister of Finance. At the general election in January 1874, the cry of protection for Canadian industries was again raised at Hamilton, the traditional home of the National Policy movement in Ontario. The Canadian Pacific scandal, however, monopolised the attention of the electorate; and the first Liberal Government since Confederation 
was returned to power with a majority of sixty in the House of Commons. ${ }^{1}$

It was a supporter of Mackenzie's Government-Andrew T. Wood of Hamilton-who had raised the cry of protection in the election of 1874. Wood had advocated an increase in duties from fifteen to twenty per cent at the annual convention of the Dominion Board of Trade, which had preceded the elections of 1874 . He attended this convention at Ottawa in his capacity as President of the Board of Trade of Hamilton; and in his address to the electors he had declared that he was no Cobdenite, and had advocated a remodelling of the tariff so as to give such protection to Canadian industries as would enable them to compete successfully with the cheaper labour of foreign countries. ${ }^{2}$

Other members of the House of Commons elected as supporters of the Mackenzie Government during the heat of the popular uprising against the scandal of 1873 were what might be termed, in the phraseology of the BlaineCleveland campaign of 1884, "Mugwumps." It was chicfly Blaine's connection with the Little Rock Railway scandal that developed the Mugwump movement in the United States, and in 1884 elected Cleveland as President. It was the Canadian Pacific

1 Cf. Goldwin Smith, Canada and the Canadian Question, p. 225 ; Hansard (British), series iii. vol. cexvii. pp. 1430-31; Mackenzie's Speech at Kingston, Ont., June 27, 1887, on the Early Struggles of the Canadian Reformers, reprinted in Long, Canadian Politics, pp. 162, 163 ; Castell Hopkins, Chronology of Canadian History, pp. v. vi.

2 Cf. Prominent Men of Canada, pp. 365, 366. 
scandal that gave Mackenzie his majority in 1874. The Mugwump movement in Canada in 1874 was as well developed as that in the United States Presidential election of ten years later. As the Parliament of 1874-78 wore on, this temporary element in the Liberal party was at times a difficult one for Mackenzie to handle; and on no question was it more difficult to keep in line than on the tariff.

Wood's election address at Hamilton in 1874 has a twofold significance in the history of protection in Canada. $\mathrm{He}$ was the first politician, who was also a manufacturer, to advance the plea that Canadian industries must be protected from cheap foreign labour. This was a new plea in the National Policy propaganda; for it will be remembered that in 1859, when Galt was justifying his policy to the Colonial Office and the Committee of Privy Council for Trade, he urged that manufacturing was necessary in Canada to find employment for men who were not suited for the farm. The second reason for regarding Wood's address as a landmark is that in it may be discerned the germ of the movement that led to the National Policy Tariff of 1879 . Macdonald in 1872 had seen that an election might be won on the cry of protection to home industries; and as he gradually rehabilitated himself during the Parliament of 1874-78, the feasibility of carrying the next election on the protectionist cry became stronger. 


\section{CHAP'TER X}

THE FIGHT IN PARLIAMENT AND IN THE CONSTITUENCIES FOR THE NATIONAL POLICY. $1874-1878$

Shall we not say Canada is for the Canadians, and protect our markets for ourselves? Shall we not say if we have a short crop, our own people shall consume it, and pay a fair price for it.-MACDONALD. I CANNot tell what protection you require. But let each manufacturer tell us what he wants, and we will try to give him what he needs.-Macdonald.

THE upshot is that on the neck of the Canadian, as of the American Commonwealth, now rides an association of protected manufacturers making the community and all the great interests of the country tributary to their gains. Before a general election the Prime Minister calls these men together in the parlour of a Toronto hotel, receives their contributions to his election fund, and pledges the commercial policy of the country.-Goldwin SMith, 1891.

The financial exigencies of the Dominion, in 1874, compelled the Mackenzie Government to increase the scale of tariff duties from fifteen to seventeen-and-a-half per cent, and to impose new duties of from five to ten per cent on a number of partly manufactured articles that had hitherto been on the free 
list. 'These changes were for revenue only, and were in no sense a response to the demands for more protection for labour and industries which in 1873 and in 1874 had been made by the Dominion Board of 'Trade, and at Hamilton. A general revision of the tariff was necessary to make these changes. This revision of 1874 was the only general revision while the Mackenzie Government was in power; and it stands out in the fiscal history of the Dominion as the last revision by a free-trade Minister of Finance, supported by a Liberal and free-trade administration. There have been six or seven general revisions since 1874; but all these have been made in a protectionist spirit and by protectionist Ministers of Finance.

Between 1874 and 1876 Mackenzie was made increasingly conscious that there were among his supporters in the House of Commons a number of members whose sympathies were not with the administration in its free-trade policy; and in February 1876 it was only the intervention of the Liberal members from the Maritime Provinces that prevented the Mackenzie Government from enacting a tariff by which duties would have been increased from seventeen-and-a-half to twenty per cent. Among the Ontario supporters of the Government there was a group which was insistent that some concessions should be made to the protectionist movement in that province, and in 1876 
Sir R. Cartwright framed a tariff to that end. But the Liberal members from the Maritime Provinces, as soon as they had news of the proposed changes, met in conference, and presented a protest to the Government, in which they affirmed that if duties were increased in response to the Ontario cry for protection, at the next general election few Liberal members would be returned from New Brunswick, Nova Scotia, and Prince Edward Island. Mackenzie reconsidered his position. The proposed tariff was abandoned, and the Mackenzie Government decided to stand or fall by the free-trade policy which it had embodied in the tariff of 1874 .

The intention of the Government to increase duties had become known beyond the ranks of its supporters in the House of Commons. It had, in fact, been semiauthoritatively announced in the Globe, and also in the Patriot of Charlottetown, Prince Edward Island; ${ }^{1}$ and when the proposed change was abandoned, and a budget introduced which was no more protective than the budget of 1874, Macdonald, Sir Charles 'Tupper, and other members of the Opposition

1 "'Mr. Cartwright's budget speech to-morrow keeps all sections of politicians on the tip-toe of expectation. It is known that he favours an increase of the tariff to meet the deficit of over one million dollars, which must occur in spite of the reduction of expenditure approaching $\$ 600,000$. Those opposed to an increase of the tariff propose an issue of $\$ 1,000,000$ or more of Dominion notes, redeemable at a certain time. The majority of the Maritime members strongly oppose any change in the existing tariff. They, informed the Premier of their views through $\mathrm{Mr}$. Church to-day." -Ottawa Correspondence, Patriot, February 24, 1876. 
made much of the fact that the Government was not disposed to help Canadian industries.

"We had," said Sir R. Cartwright, speaking for the Government, in answer to these attacks on March 10, "no intention whatsoever of committing ourselves to the policy of protection; and I tell the honourable gentlemen opposite, once for all, that although the Government gave very serious consideration to this question, and took great pains to decide what was their duty in this crisis, they did not at any time entertain the idea of levying what is called a protective tariff. We admit that when a Government have to levy duties, they should be imposed to promote the good of the greatest possible number. We also admit that it is our duty to advocate a policy in the interest of Canada alone. But $I$ repeat once more, in the most positive and explicit manner, no man was justified under whatever circumstances in stating that any member of this Government had an intention to meddle with the tariff." "We know," the Minister of Finance added, "that we must have a customs tariff; and although I do not believe in incidental protection, still I am willing that the tariff should be so distributed as to give an advantage-not in endeavouring to settle manufactures here that do not belong to us - to the particular classes of industry which will naturally grow up in the country."

1 House of Commons Debates, March 10, 1876. 
It was during this crisis of 1876 , when Mackenzie and the Liberals had been called upon to make their decision as to concessions to the protectionists, that Sir W. Laurier, who had come into Parliament at the general election of 1874, and had immediately distinguished himself in the debate on the address, made his first speech on the fiscal policy of the Dominion. Later on ${ }^{1}$ he joined the Mackenzie administration as Minister of Inland Revenue. But in March 1876, when this, the first debate in the Dominion House of Commons on protection for Canadian industries, took place, Sir W. Laurier was only of the rank and file of Mackenzie's supporters. He was then without first-hand knowledge of the working of a protective system-of its economic effects or its effect on political morality; and his cautious balancing speech of 1876 is in marked contrast with the rousing speeches which he made against protection-his unsparing condemnation of it at Winnipeg and at Ottawa-after the National Policy of 1879 had been tried for twelve or thirteen years. His speech of 1876 is lawyer-like and opportunist in tone. In some respects it is the kind of speech that he might make to-day, after he has been for eleven years at the head of an administration as protectionist as any of the Conservative governments that were in power between 1879 and 1896 ; and is having showered on 1 October 8, 1877. 
him the praise of the Conservative National Policy newspaper press. ${ }^{1}$

At the outset Sir W. Laurier taunted the Conservatives with their recent conversion to protection. "I was not aware until very recently," he said, "that the party had any policy on this question. At least their leaders never avowed any. It is true, from what we have seen in the House, that the great mass of the party seems to be protectionist; but it is equally true that they have only within two or three days come to adopt that policy openly." "The question of free trade and protection in any country," he continued, "is not to be applied to political motives; but to be treated as a matter of pure economy, and its solution depends entirely on the condition of the country. It cannot be denied that free trade or protection is to be applied according to the necessities of a nation. Protection is a matter of necessity for a young nation in order that it may attain the full development of its own resources. If I were in Great Britain I would avow free trade; but I am a Canadian, born and resident here, and I think that we require protection. I consider, however, that the present tariff ${ }^{2}$ affords sufficient protection. We have had many changes in the tariff sinee the adoption of our fiscal policy twenty years ago; but the manufacturers never made any

1 Cf. Citizen, Ottawa, June 27, 1907.

2 The duties were at the rate of seventeen-and-a-half per cent. 
complaints until the crisis came eighteen months ago." 1

It is a tradition at Ottawa that the Conservative leaders were prepared to attack the Government had it increased duties to twenty per cent in 1876 ; that the leaders had their speeches ready for such an attack, and were compelled to recast them at the last moment when it was announced that the Mackenzie Government was to propose no general changes in the tariff. Sir W. Laurier's speech is not without evidence of preparation; for with slight changes in phraseology it might have been volunteered as a defence of the Government had Mackenzie's first intentions with regard to fiscal legislation not been frustrated by the opposition of the members from the Maritime Provinces. Whether or not there is any truth in this tradition of the attack that was to be made by Sir Charles Tupper, the decision of the Government to adhere to its free-trade policy gave the Conservatives an opportunity of which they promptly took full advantage.

The Conservative party in this session of 1876 took up ground far in advance of that on which it had stood when it adopted the merely retaliatory policy of 1870 ; and for the first time since Confederation it avowed itself the party of protection. In and out of Parliament it threw itself so generally and so vigorously into the new movement that from March 1876 protection became the foremost

${ }^{1}$ House of Commons Debates, March 10, 1876. 
question in Dominion politics - a prominence which it has occupied ever since. Outside Parliament the most significant movement in 1876 was a convention of manufacturers at Toronto, at which there was the first suggestion that it was practicable to do what the Laurier Government did in 1897 - to enact a tariff which, while protecting Canadian manufacturers, should establish some preference for imports from Great Britain. The Toronto proposal was that the tariff on all imports from the United Kingdom, which could be made in Canada, should be increased to twenty per cent; and that on all imports from the United States the Canadian duties should be the same as those imposed by the United States tariff. ${ }^{1}$

The Toronto Convention gave an impetus to the movement in Parliament; and in this session-1876-and the two succeeding sessions -1877 and 1878 -resolutions in favour of the National Policy were proposed from the Opposition benches. On the House going into committee of supply in March 1876 , Macdonald proposed a motion in which regret was expressed that the Governor-General had not been advised to recommend to Parliament a measure for the readjustment of the tariff, which would not only aid in alleviating the stagnation of business deplored in the speech from the throne; but also afford fitting encouragement to struggling manufactures and

${ }^{1}$ Cf. House of Commons Debates, March 10, 1876. 
industries, as well as to the agricultural produets of Canada.

Maedonald, in speaking to this resolution, deelared that the farmers were in favour of protection to industry, and in support of his argument called attention to the bonusing of industries, which by this time had begun in the towns and eities of Ontario. "The farmers," he said, "voluntarily taxed themselves to grant bonuses of large sums of money to encourage manufacturing industries in their midst. It is a conclusive proof that the people of the country are in favour of, and are willing to tax themselves to encourage manufaeturers, and if we can foster manufactures by putting a tax on foreign produce they will be equally, if not more, in favour of that mode of encouragement than by taxing themselves to grant bonuses." 1

The Government was able to defeat the resolution $;^{2}$ but, as Macdonald elaimed, when he proposed his more eomprehensive resolution in 1878, the Conservatives had the satisfaction of seeuring not only the full opposition vote, but also the votes of several members who usually supported the Government. ${ }^{3}$ In the next session of Parliament-1877-when the Minister of Finance reported a defieit of nearly two million dollars, and the Government increased the duties on tea, malt, and

1 House of Commons Debates, March 10, 1876.

2. 116 votes to 70 .

s Cf. House of Commons Debates, March 7, 1878. 
malt liquors, Macdonald again put forward a National Policy resolution. This time regret was expressed that the financial policy of the Government increased the burden of taxation without any compensating advantage to Canadian industry; and the House of Commons was asked to declare that it was its opinion that the deficiency in revenue should have been met by a diminution of expenditure, and by such a readjustment of the tariff as would benefit and foster the agricultural, mining, and manufacturing industries of the Dominion. At this time the coal mining companies of Nova Scotia were petitioning for the re-enactment of the duty of fifty cents a ton on coal, which had been repealed in 1871. Hence the inclusion of mining among the industries that were to be fostered by the National Policy.

Macdonald, in urging this resolution of 1877 on the House, attacked the Mackenzie Government for missing a great opportunity of adopting a fiscal policy that would be of advantage to Canadian industries. With a deficit to meet the Government should so have adjusted taxation that it might incidentally have been of service to some interest, some industry or manufacture. He then threw himself into the patriotic attitude of caring all for country and nothing for party, and warned Mackenzie and his followers on the Treasury Bench that by failing to avail them-

1 Cf. National Policy Resolutions, House of Commons Debates, March 7, 1878. 
selves of their opportunity of adopting the National Policy they were playing the game of the Opposition, and strengthening its position in the constituencies.

The Government, however, was steadfast to its determination of 1876 . "A very slight consideration of the laws of trade and commerce," said Mackenzie, in answer to Macdonald, "must satisfy the House and the country that if any trade is to be fostered it must be fostered at the expense of some other trade or party. We cannot make money out of air. The mere passing of an Act of Parliament will never establish any trade, and will never foster any industry, unless it be to change from one pocket to another the proceeds of the industry of the country. There is no policy more consistent with what we call the Dark Ages of the world than that of protection as a principle. There is no principle more consonant with the advance of human freedom than absolute freedom of commerce. Our policy at the present time is to avoid, as far as possible, placing a burden of taxation upon the people; and to endeavour to make everything as cheap as the state of the revenue will admit." 1

Seven full days were taken up with the debate on Macdonald's resolution. As in 1876, it was defeated-seventy for, and a hundred and nineteen against. ${ }^{2}$ But even when the 
resolution had been disposed of, Macdonald continued the fight. When Sir R. Cartwright proposed the budget resolution increasing the duty on tea, Macdonald moved that it be referred back to the committee of ways and means, with an instruction that the committee should have power to substitute for the duty on tea "some tax that, while bringing to the treasury an equivalent amount of revenue, will at the same time aid the various industries of the country."

Only the intervention of the chair prevented Macdonald from going once more at length into the general question that had been so fully debated on the resolution that was defeated on March 23. Thus confined to the narrower issue, Macdonald's plea was that the Government had indubitable evidence from all parts of the Dominion that commerce and trade were depressed, and that they might have framed the tariff so that while it would raise revenue, it would also in some degree give encouragement, support, and cheer to various struggling industries. This second resolution was negatived $;^{1}$ and its only importance now is that it affords proof of the ease with which an Opposition could obstruct a tariff bill; for dilatory motions, against which only closure by compartment could be applied, are possible on almost every item in a tariff.

1 By 119 votes to 67 ; House of Commons Debates, April 5, 1877. 
All the energies of the Conservative party in the session of 1877 were devoted to forcing the question of protection to the front, and in the Parliamentary recess the leaders of the party were busy in the constituencies with the new propaganda. One of the most callous speeches in support of protection ever made by a Canadian politician - the most coldblooded argument ever advanced in favour of it until the stove and the coffin-makers appeared before the Tariff Commission at Hamilton, in November 1905-was made at this time by Macdonald at Stanstead, in the Eastern Township of Quebec. These are the townships that were settled by Bear Ellice's colonisation company in the 'twenties and 'thirties of last century - settled by English families - and where ever since English-speaking farmers have been more numerous than in any other part of Quebec. It was in urging the advantages of the Natioual Policy on the farmers of the Eastern Townships that Macdonald made the speech that even his colleagues of the Conservative party never cared to recall. In this speech Macdonald afforded an example of what Sir R. Cartwright, in his Opposition days-1879 to 1896 -was wont to call the "barbarous instinct of the protectionist mind."

" "Shall we not say," Macdonald then urged, "Canada is for the Canadians, and protect our markets for ourselves. Shall we not say if we have a short crop, our own people shall con-

${ }^{1}$ Cf. House of Commons Debates, April 11, 1890. 
sume it, and pay a fair price for it. At the end of my long political career, the last effort I am going to make, the culminating struggle before I retire into private life, is to attempt to get a National Policy for Canada; to secure a National Policy; a policy by which we will be able to get a fair day's wage for a fair day's work-by which we will not be trampled upon and ridden over, as we have been in the past, by the capitalists of a foreign country. We will say to the United States, "We were free traders. We took our cue from the Mothercountry. We did not recognise the difference between the circumstances of an old country and a new one like ours. We will pay you the compliment of saying we were wrong and you were right; and we will do to you as you do to us.'

Short Parliamentary sessions were the rule at Ottawa for the first decade after Confederation. The session of 1878 lasted only from February 8 to May 10 . The tariff was the only subject that was seriously discussed, and into these debates the Conservatives threw themselves with even more zest than in either of the two previous sessions. Macdonald's rehabilitation was by this time complete. A month before Parliament met he had been entertained at dinner by the Conservative working men of Toronto, and presented with a gold watch and chain. A week later the Conservatives of Ontario had met in convention at Toronto, and endorsed Macdonald's course 
of action as leader of the Opposition on the tariff question. The session of 1878 was to be the last of the then existing Parliament, and both these Toronto demonstrations, and the speeches of the Conservative leaders in Parliament, were with a view to the general election in August.

There were two debates in the House of Commons-the first on Sir R. Cartwright's last budget, and the second on Macdonald's National Policy resolution. Both are memorable in the history of protection in Canada; for in the debate on the budget Sir C. Tupper elaborated the suggestion of the manufacturers' convention at Toronto of 1876 for a protective tariff with preference for British imports; while Macdonald's resolution of March 7, 1878, has ever since been regarded as the basis of the National Policy which has been in operation since 1879.

Sir Charles Tupper, in the temporary absence of Macdonald, was leading the Opposition when, on February 22, Sir Richard Cartwright submitted his budget to the House-a budget in which, for the third time during his four years as Minister of Finance, he had to report a deficit. Sir R. Cartwright was well aware that the Conservatives were to make an onslaught on the fiscal policy of the Mackenzie Government-to move what amounted to a vote of want of confidenceand he anticipated the attack in his budget speech. He recalled Macdonald's outburst in 
favour of protection at Stanstead, and the resolutions of the Conservative convention at Toronto, in which it was declared that the welfare of Canada required the adoption, permanently and not as a temporary expedient, of a National Policy which, by a judicious readjustment of the tariff, would benefit and foster the agricultural, the mining, and the manufacturing interests of the Dominion.

"My object at present," said Sir R. Cartwright, after he had read the Toronto resolutions to the House, "is neither to comment on that remarkable speech nor on those remarkable resolutions, but to draw your attention to the fact that they involve an absolute contradiction of the policy laid down by this Government. The position taken up by the honourable gentlemen of the Opposition is, as I understand it, this - that it is in the power of the Government to increase the collective wealth of the country by increasing the taxation, and that they can enrich the community collectively by taking money out of their pockets. It may be so. On the other hand, our position, equally clear, equally welldefined, for which we are at least equally willing to fight to the death, and which we are determined so far as we can to carry out, is this-that all taxation, however disguised, is a loss per se; that it is the duty, and the sacred duty of the Government, to take from the people only what is necessary to the proper discharge of the public service; and 
that taxation in any other mode is simply in one shape or another legalised robbery."

As soon as Sir R. Cartwright had thus reaffirmed the convictions as to protection which he had expressed in 1876, Sir C. Tupper, without proposing any resolution-for Macdonald was to submit that at a later stagebegan a long speech in which he maintained that a protective policy was at that juncture absolutely necessary for the Dominion. $\mathrm{He}$ was confident that in adopting such a policy Canada would meet with no objections from the British Government. "I say," he continued, "that this policy could be adopted-a revenue policy, or such a policy with relation to goods coming from Great Britain or from British possessions as the necessities and the fiscal policy of Canada indicated, and 'another policy for the rest of the world. That would apply only to the United States practically; because our imports from other parts of the world are almost uniformly articles upon which there are specific and not ad valorem duties; and we could adjust them in the interests of Canada as we pleased. I have no doubt that this would meet the only serious difficulty standing in the way of a truc Canadian policy, and one that those who wish to see Canadian enterprise and Canadian industries flourish feel that it is time she should grapple with earnestly and deal with as I have mentioned." ${ }^{2}$

1 House of Commons Debates, February 22, 1878.
2 Ibid. 
CH.

Sir Richard Cartwright's answer was brief. After having announced in the budget speech what the Government position was, he left further reply to Mr. Paterson and other members of the Liberal party, merely denying the statement that the Government had no fiscal policy - no platform on which it was going to the constituencies at the approaching general election. "I think," he said, "the policy of the Ministry has been announced at various times in a tolerably distinct fashion from this place by myself and other gentlemen who sit beside me. I think no man can justly complain as to the policy which we think best adapted to the circumstances of the country -as to the policy which we are prepared at all hazards to justify and maintain." ' This was Sir Richard's last word in the debates of 1878 - the last defence of free trade he made from the Treasury Bench of the House of Commons; for neither he nor Mackenzie intervened in the later debates of the session on Macdonald's famous resolution.

Mr. Paterson, who has been Minister of Customs in the Laurier Government since 1896, replied for the Liberals to the suggestion of Sir Charles Tupper of a protective tariff with preferences for Great Britain. $\mathrm{He}$ regarded it as impracticable, and as most unadvisable even if it were practicable. A tariff so framed, he contended, would mean a

\footnotetext{
1 House of Commons Debates, February 22, 1878.
} 
retaliatory tariff against the United States; and if retaliatory duties were adopted, which country, he asked, would suffer most, the United States or Canada? The loss would undoubtedly fall on Canada. Hence the retaliatory policy and the preferential duties would not stand examination. Mr. Paterson then recalled the fate of the Irving and Wood resolution of 1876 -in which a protective tariff with preferences for Great Britain was urged - and the ridicule that Macdonald then threw upon it; and refused to believe that Sir C. Tupper was serious in suggesting a protectionist tariff with preferences for Great Britain. It was, he insisted, merely an electioneering device, by means of which Sir C. Tupper was endeavouring to lead people to believe that he could maintain his claim, and the claim of the Conservative party, to pre-eminence in loyalty over the Liberal party, and at the same time advocate duties which he pretended were in the interest of Canada. ${ }^{1}$

There was much clever stage management on the part of the Conservatives and protectionists for the general election of 1878 . These tactics began in January with the presentation to Macdonald by the working men of Toronto. Times were bad and trade was depressed; and in anticipation of the debate on the budget in February, it was proposed by the Conservatives that there

1 House of Commons Debates, February 26, 1878. 
should be a demonstration of the unemployed on Parliament Hill.' $\quad$ Sir C. 'T'upper's advocacy of a preferential tariff for Great Britain seems to have been a stage device. In any event this zeal of the Conservatives for preferences for British imports was new born and not long lived. There was no suggestion of a preference for Great Britain when, in 1870, the British carrying trade to and from the St. Lawrence was dislocated by the duty of fifty cents a ton on coal. Excepting salt, no trace of any preference for British imports can be found in the National Policy tariffs from 1879 to 1896 , or in the debates in 1879 on the first avowedly protectionist tariff. All interest in the Conservative party in preferences for Great Britain came to an end after Macdonald had secured a majority in the general election in 1878; and after the Liberals in 1897 enacted the preferential tariff its most persistent opponents in the House of Commons were the Conservatives, who since 1897 have continuously demanded that there should be no preference in Canada for British imports until a preference is established at British ports for grain, food stuffs and lumber from the Dominion.

Macdonald's resolution, in which culminated the three years' fight for protection waged by the Conservatives in Parliament, was submitted on March 12, on the motion to go into committee on the budget resolutions. "This

I Cf. Notes from the Capital, Globe, February 12, 1878. 
House is of opinion," it reads, "that the welfare of Canada requires the adoption of a National Policy, which by a judicious readjustment of the tariff will benefit and foster the agricultural, the mining, the manufacturing, and other interests of the Dominion; that such a policy will retain in Canada thousands of our fellow-countrymen who are now obliged to expatriate themselves in search of the employment denied them at home; will restore prosperity to our struggling industries now so sadly depressed; will prevent Canada from being made a sacrifice market; will encourage and develop an active inter-provincial trade; and moving, as it ought to do, in the direction of a reciprocity of tariffs with our neighbours, so far as the varied interests of Canada may demand, will greatly tend to procure for this country eventually a reciprocity of trade." 1

The leader of the Opposition was in a confident and jaunty mood when he rose to make his last great attack on the fiscal policy of the Mackenzie Government. After he had read his resolution, a member on the Government benches asked, "Is that all ?" "It may," answered Macdonald, "be too much for you." "That," he continued, "is the resolution which I submit to this House; and I do not think any honourable gentleman will say we have not taken our stand upon a policy. It may be a policy that the honourable gentle-

1 Journals of House of Commons, March 12, 1878. 


\section{PROTECTION IN CANADA сн.}

man (Mackenzie) does not think a good one. If so, he will have the advantage. He will go to the country and, I have no doubt, point out the fallacy of it; and if we are wrong we must submit to the consequences of our error. But we believe that the resolution embodies a policy which will be accepted, and accepted warmly by the country; and that this country will declare, in the words of the resolution, 'that the welfare of Canada requires the adoption of a National Policy.'"

Macdonald's general argument was that if Canada had a protective system - if the factories of Canada were fenced around with protection-if there was enacted a tariff such as the necessities of Canada demanded, and manufacturers in Canada were given a hold on its four million people, they would be able to develop their resources, and would soon rank with manufacturers in the United States. He next advanced the argument that has been heard at every tariff revision since 1879 - the argument that there are men in Canada unfitted for the farm, or with abilities superior to farm work, and that it is the duty of the Dominion Govermment to give these men opportunities for remunerative employ-, ment suited to their abilities. "We must," he said, "by every reasonable means employ our people-not in one branch of industry, not merely as farmers or tillers of the soil; but we must bring out every kind of industry -we must develop the minds of the people 
and their energies. Every man is not fitted to be a farmer, to till the soil. One man has a constructive genius. Another is an artist. Another has an aptitude for a trade. Another is a skilled mechanic. All these men are to be found in our nation; and if Canada has only one branch of industry to offer them, if these men cannot find an opportunity in their own country to develop the skill and genius with which God has gifted them, they will go to a country where their abilities can be employed, as they have gone from Canada to the United States."

In explaining what he meant by a National Policy, Macdonald admitted that "a judicious readjustment of the tariff"a tariff intended to foster home industrieswould necessarily involve increased duties on certain articles. It would mean increased duties on those manufactures which could be produced in Canada. It would mean higher duties on woollen, cotton, and other goods; but lower duties on articles of general consumption which Canada could not produce. But he contended if a man were obliged to pay more on his cottons, and at the same time had to pay a cent less on his tea, "it would be found by calculation that he was a gainer by the operation."

Another argument advanced by Macdonald was that it was the duty of the Government to prevent Canada from being made a slaughter market for American manufacturers. He 
asserted that under conditions then existing, with duties of only seventeen-and-a-half per cent, Canada was both a slaughter and a sacrifice market for the United States. Canada was overwhelmed with the sweepings of American factories, sold at slaughter market prices; and it was also made a sacrifice market by American manufacturers who were desirous of making an end of Canadian industries, and thus preventing Canadian competition in the Canadian market. "We all remember," said Macdonald, in emphasising his contention that it was imperative that Canada should cease to be a sacrifice market, "what the salt manufacturers of the United States did when the salt manufacturers first opened work at Goderich. The salt manufacturers of Syracuse and Salena sent in their salt with instructions to undersell Canadian salt in the Canadian market, to crush this infant industry. The shoe trade was dealt with in the same way by the manufacturers of the United States. In a young country like this, manufacturers are obliged to depend a good deal upon credit for the capital they have not themselves; so that when such a rush as this is made from the United States the manufacturer in the particular branch attacked falls helplessly. He is unable to sell his wares to meet his banking arrangements. $\mathrm{He}$ becomes insolvent; the manufactory is closed; the people are discouraged; and they go off to the States." : 
Reverting to the slaughter market contention as distinct from the contention that Canada was used as a sacrifice market, Macdonald reminded the House that American manufacturers controlled their own market; but that at times there was over-production, and that when this was the case Canada was frequently used as a slaughter market. "At the end of the season," he said, "all the manufacturers have goods left which they cannot sell. They will not allow them to be sold in their markets under value. They will not sacrifice them there. But they all clear out their shops, and send the refuse over to Canada, so that they may have their warehouses ready for next year's trade. That is occurring in every town in Canada and every day."

Macdonald's next argument was that the policy he was advocating would develop interprovincial trade. In offering this argument to the House he altogether ignored the suggestion for a preferential tariff for Great Britain, and took joy in predicting that the Maritime Provinces, whose trade relations with England had always been close, would under a National Policy transfer their trade to Quebec and Ontario. "The resolution," he said, "speaks not only of a reasonable adjustment of the tariff, but of the encouragement and development of inter-provincial trade. That is one of the great objects we should seek to attain. Formerly we were a number of provinces which had very little 


\section{PROTECTION IN CANADA сн.}

trade with each other, and very little connection, except a common allegiance to a common sovereign, and it is of the greatest importance that we should be allied together. I believe that by a fair readjustment of the tariff we can increase the various industries which we can interchange with one another; and make this union a union of interest, a union in trade, and a union in feeling. We shall then grow up rapidly a good, steady, and mature trade between the provinces, rendering us independent of foreign lands, and not, as New Brunswick and Nova Scotia formerly did, look to the United States or England for trade, but look to Ontario and Quebec - sending their products west and receiving the products of Quebec and Ontario in exchange. Thus the great policy-the National Policy which we on this side are advocating-would be attained."

A smile had come over the faces of members on the Government benches when Macdonald read that part of his resolution which referred to reciprocity with the United States. He recalled this reception of the reciprocity clause, and assured the Government that if there was one subject more than another in the minds of the people of Canada at that time, it was the subject of reciprocity with the United States. "The country," he declared, "will have it. It will not have the present unjust policy. It will have fair play; and will not allow our markets to be made use of by the manufacturers of a neighbouring 
country, when they can find no better market elsewhere, and at the same time have no access to their markets. What is the consequence of the jug-handle policy? The slaughter is being made, and the goods are being disposed of at a ruinous price. You cannot have reciprocity in trade without a reciprocity in tariff. There is no wrong in a reciprocity of tariff if it is to our interest. I am confident that one great object in having something like a retaliatory policy will be that if you are to have reciprocity in trade you will only get it in that way. You have tried the policy of conciliation and humiliation long enough. We can get nothing by trying to induce them to alter their plans. They have laid down a rule, and it will be carried out. They will not have anything like reciprocity in trade with us unless we show them that it will be to their advantage. It is only by closing our doors, and by cutting them out of our markets, that they will open theirs to us. It is only, by closing the door that we get anything." Macdonald concluded by declaring his confidence that the people of Canada would accept his resolution as the enunciation of a fair and just policy, and by announcing that it was the determination of the Conservative party to fight the approaching general election on the issue which he had defined. ${ }^{1}$

The debate in the House of Commons

1 House of Commons Debates, March 7, 1878 ; Pope, Memoirs of Macdonald, ii. pp. 200, 201. 


\section{PROTECTION IN CANADA сн.}

extended over three days-March 7, 8, and 13 -and although the Opposition had persisted in treating it as a vote of want of confidence in the Government, neither Mackenzie nor Sir Richard Cartwright intervened in the debate. The Government had nothing to withdraw and nothing to add to the statement that Sir R. Cartwright had made. It was left to backbench members-Messrs. Dymond and Charlton of Ontario, Gillmor of New Brunswick, and Jones and Kirk of Nova Scotia-to defend the Government position; and on a division the resolution was defeated by 114 votes to 77, a majority of thirty-seven for the Government, as compared with the majority of sixty that supported Mackenzie in the opening days of the Parliament of 1874-78.

Parliament was prorogued on May 10. It was not dissolved until August 17. But the fight over protection went on all summer. In the constituencies Mackenzie, Sir R. Cartwright, Mills, and Sir W. Laurier and their colleagues stood firm on the ground they had taken up in the debate on the budget of 1878 . "We may be mistaken in the policy we advocate," said Sir Richard, at a demonstration at Strathroy, Ontario, " - we may be mistaken in thinking that it is not for your interest to put taxes on you except for the purpose of clear general utility, or to redeem your credit; but at least we will abide by the policy we have announced." 1

1 Cf. Globe, July 3, 1878. 
Sir W. Laurier by this time had approached much closer on the tariff question to Mackenzie and Sir R. Cartwright. At Strathroy he made a speech quite in line with his later utterances on protection at the National Liberal Convention in 1893 and at Winnipeg in 1894. Like several of the Liberals who took part in the debate on Macdonald's National Policy resolution, he was sceptical as to whether anything more would be heard of the National Policy if the general election resulted in a majority for the Conservatives. $\mathrm{He}$ ridiculed the National Policy as a scheme for making the Dominion rich and prosperous - making the land flow with milk and honey -and for making manufacturers richer by compelling them to pay more for their coal; and abandoning the ground he had occupied in 1876 and 1877, he went over completely to his free trade colleagues, and declared himself in favour of a tariff for revenue only. ${ }^{1}$

At Parkhill, Ontario, Macdonald reiterated his argument in the House of Commons of March 7, in favour of the National Policy, and amplified it by insisting that the National Policy would not favour any one class in particular; but would benefit the manufacturer, the miner, the farmer, and the artisan in common. "If this great National Policy is carried out," he added, "we shall wear clothing made from our own wool : boots made from our own leather; and all we shall

1 Cf. Globe, July 3, 1878. 
use will be manufactured by our own people." ${ }^{1}$ But Macdonald's most memorable utterance in this campaign of 1878 was at Hamiltonmemorable in view of the institution of the Red Parlour at Toronto, of which so much was to be heard in the House of Commons and in the constituencies in the period that lay between 1879 and 1897. At Hamilton, when Macdonald was successfully bidding for the support of the manufacturers-a support that was very easily secured-he was asked what protection he was prepared to give to manufacturers. "I cannot tell," was his accommodating answer, "what protection you require. But let each manufacturer tell us what he wants, and we will try to give him what he needs." 2

In Ontario, Conservative candidates for Parliament laid most stress on the success which manufacturing had attained in the United States, and on the argument that the National Policy would stop the exodus of Canadians to the United States. Figures were published by the National Policy League, which was organised at this juncture, showing that for the years $1876-77,44,500$ persons had left Canada for the Republic; and it was asserted that these Canadians could be retained in Canada by a readjustment of the tariff in the interests of the industries of the Dominion. ${ }^{3}$

Conservative newspapers, like the Mail of

1 Cf. Globe, July 5, 1878.

${ }^{2}$ Cf. Buckingham and Ross, Life of Mackenzie, p. 508.

${ }^{3}$ Cf. Glube, July 6, 1878. 
'Toronto, appealed to the electors "to stamp out starvationists" - this was the term applied to the Liberals - " and bring back a rich prosperity to Toronto and the Dominion at large." "The National Policy, as we have often said," wrote the Mail on the day following the election, "was long since adopted as the economical creed of the people. Whether a handful of manufacturers ought or ought not to grow wealthy under it was a matter of infinitesimal concern to them. All the people demanded was fair and equal play with their neighbours in the United States in the struggle for existence." I

"Down by the sea," in New Brunswick, Nova Scotia, and Prince Edward Island, where in 1878 high duties were no more popular than they were in 1870-71 when Macdonald was compelled to repeal the duties on coal and flour, the Conservative candidates, ignoring Macdonald's admissions when he proposed his resolution in the House of Commons, affirmed that only a readjustment of the tariff, and not an increase in duties, was the policy to which the Conservatives were committed. ${ }^{2}$

Liberal newspapers answered these statements from Conservative platforms by insisting that there could be no readjustment of the tariff on the lines Macdonald had urged without large increases in duty. "The Govern-

1 Mail, Toronto, September 19, 1878.

${ }^{2}$ Cf. Buckingham and Ross, Life of Mackenzie, p. 508. 


\section{PROTECTION IN CANADA сн.}

ment press," wired Boyd of St. John to Macdonald, "state that you propose to raise the tariff generally to twenty-five per cent. Can you contradict this?" Macdonald was a politician with little regard for truth or for the square deal in politics. Political morality was something for which he never even pretended any respect. He was ready at any time to make any contradiction that would serve his ends or help him over a difficulty. He found it convenient at some times and in some places at this election of 1878 to ignore what he had said in the House of Commons three months earlier as to the National Policy of necessity involving increases in duties, and he wired back to his St. John correspondent that the statement in the Liberal newspapers was an absurd falsehood. "Neither in London (Ontario) nor elsewhere have I gone beyond my motion in Parliament, and have never proposed an increase, but only a readjustment of the tariff." 1

It was by glaring and impudent misstatements like these that in Nova Scotia and New Brunswick - provinces too remote to realise the actual aim of the protectionist movement in Ontario - that the Conservatives carried seats for the National Policy candidates. Even as far back as 1878 electioneering methods in Nova Scotia were no better than those which were exposed in 1906, when Mr.

1 Telegram, Macdonald to Boyd, July 22, 1878, quoted in House of Commons Debates, March 18, 1879. 
Fielding was unseated for giving money to an agent, who used it for bribery. The agent decamped to avoid giving evidence, when the petition at last came up for trial, after nearly two years of delay due to service-dodging and other obstructive legal tactics, intended to wear out the petitioner-tactics that would for ever have ruined the political career of a Parliamentary candidate in England. Mr. Fielding had then no option but to admit that he had contravened the Dominion statute, which was aimed at just such practices as those to which he had been a party.

Mackenzie had not gone into the general election of 1878 with much hope of success. He knew that his majority of sixty in 1874 was due entirely to special circumstances that were popularly forgotten by 1878 ; for the democracies of the New World-of Canada as well as of the United States-have proverbially short memories. Mackenzie had realised before Parliament was dissolved that the Mugwump Conservatives in the constituencies who supported Liberal or Reform candidates in 1874-those who had broken with Macdonald over the Canadian Pacific Railway scandalwere returning to their old allegiance. He was aware that some of his supporters from industrial constituencies in Ontario and

${ }^{1}$ Cf. Cowie $v$. Fielding, Weekly Herald, Halifax, September 7 , 1906 ; Election Scoundrels, editorial article, Witness, Montreal, August 18, 1906; Election Funds, editorial article, News, Toronto, August 20, 1906; article on Queen's Shelbourne Petition, News, Toronto, Augnst 29, 1906. 


\section{PROTECTION IN CANADA сн. $\mathrm{x}$}

Quebec-even men who before 1874 had been steadfast in their adherence to Liberalismfrom self-interest were at heart with Macdonald in his advocacy of protection. He was aware also that the expenditures of the Liberal Government, due to engagements by the Macdonald Government of 1872-74, had been much larger, and had entailed higher taxation, than he and his colleagues of the Liberal party had anticipated in 1874 . In addition to these political conditions - all adverse to the Liberal party - trade in 1878 was still depressed; prices for farm produce all over the Dominion were low; and the financial outlook was discouraging. In retrospecting the general election of 1878 Mackenzie characterised it as a carnival of fraud and misrepresentation. ${ }^{1}$ However this may be, and there is certainly no reason for regarding the election of 1878 as less corrupt than general elections since then, ${ }^{2}$ Macdonald at the polls in September secured a majority of sixty-eight-137 Conservatives to 69 Liberals -and in 1879 the first National Policy tariff, with high protective duties for Canadian manufacturers, was enacted; and Macdonald was sworn a member of the Imperial Privy Council and banqueted at Quebec and Ottawa.

1 Cf. Buckingham and Ross, Life of Mackenzie, p. 507.

2 Cf. Goldwin Smith, Canada and the Canadian Question, pp. 224, 225 ; Election Funds, News, Toronto, August 20, 1906. 


\section{CHAPTER XI}

\section{THE NATIONAL POLICY IN OPERATION. 1879-1896}

THE ERA OF THE RED PARLOUR

What corruption can be more pestilential or more dangerous to the commonwealth than the surrender of the commercial policy of the country to private interests in return for their votes and the support of their money in elections? No President of the United States, being a candidate for election, could without wreck of his character and prospects, assemble the protected manufacturers in a room at an hotel, and receive their contributions to his election fund.Goldwin Smith.

KNowing as we do from dearly bought experience how grievously this Legislature and our Provincial Legislature have suffered in times gone by from improper influences, brought to bear on them by wealthy and powerful corporations, or even by wealthy and powerful individuals, we find the Minister of Finance deliberately making it to the interest of the wealthiest and most active classes of the community to obtain anyhow and by any means whatever, power over the Legislature of the country. - Sir Richard Cartwright.

Tilley-Sir Leonard Tilley of New Brunswick -was about the least inspiring speaker who ever submitted a budget statement to the House of 
Commons. He had not a particle of the dash and recklessness characteristic of Macdonald in debate; none of the fluency and command of vehement language for which Sir C. Tupper is remembered at Ottawa ; and none of the rasp and sting so characteristic of Mr. Foster, who was his successor as Minister of Finance in the Conservative Governments which survived until 1896. The exposition of the first National Policy tariff could hardly have fallen to a man less equal to his opportunities than Tilley. His speech of March 14, 1879, when he occupied the House of Commons for three hours in unfolding the policy that was to bring prosperity by Parliamentary enactment, is about as inspiring reading as a voters' list or the manifest of an Atlantic steamer. It calls for notice here only because it was the first statement of the fiscal policy of the Macdonald Government; and because here and there in the twenty odd pages of the House of Commons debates, over which the speech extends, there are significant side-lights on the framing of the first of the protective tariffs of 1879-96.

The Government, Tilley assured the House, had at the outset of the work of framing the new tariff " turned their attention to the best means of reducing the volume of imports from all parts of the world." With this end in view they had been in counsel with the manufacturers. At later tariff revisions the manufacturers have needed no inviting. They 
have been on hand with their patriotic and disinterested counsel just as soon as it was whispered abroad that the Government was once more "turning their attention to the best means of reducing the volume of imports"; and on these occasions, ever since Tilley called them into counsel in 1879, they have been willing to travel, at their own expense, from the east and from the west, and to stay for a week or more in Ottawa, to help the Government in the delicate and intricate business of drafting tariff schedules which shall achieve the end at which for nearly thirty years the National Policy has been aimed.

Macdonald told the manufacturers at Hamilton that he did not know what protection they required; "but," he added, "let each manufacturer tell us what he wants, and we will try to give him what he needs." At that time Macdonald was still leader of the Opposition. He was not then able, on behalf of the Government, to invite the manufacturers into counsel at Ottawa. The invitation came after Macdonald had secured his majority ; and Tilley, who was above all a man of detail, was careful to tell the House that the manufacturers had been in Ottawa at the invitation of the Government. "We have," he said, "invited gentlemen from all parts of the Dominion, and representing all interests in the Dominion, to assist us in the readjustment of the tariff, because we did not feel that we were prepared without advice and assistance from men of 
experience with reference to these matters to readjust and make a judicious tariff. We therefore invited those who were interested in the general interests of the country or interested in any special interests."

There was none that offered excuses; and the outcome of these counsels was a tariff in which the duties of seventeen-and-a-half per cent of 1876 were replaced by duties ranging from twenty to forty per cent. The Minister of Finance was full of regret that the era of prosperity to be inaugurated by the enactment of the National Policy was to be begun with an increase of taxation. But there was a reason for it. "To-day," he said, "all must admit that the trade of the country is greatly depressed. For agricultural products we have a limited market, low prices, and anything but a satisfactory market abroad." In levying increased taxes by a National Policy tariff there were compensations; for the tariff was to be so adjusted - schedules so arranged without being specifically differential - that most of the additional money required in the treasury would, Tilley was persuaded, be derived from imports from the United Stateson the wares of the Americans who had been wantonly using Canada as a slaughter and sacrifice market. Tilley did not suggest that the American exporter would pay the tax ; but he did insist that this new tariff would fall more heavily on the exporter in the United States than on the exporter in Great Britain. 
Except in the case of salt, there was to be no direct preference for British imports; no adoption of the tariff scheme that Sir Charles Tupper had advocated when the Conservatives were in opposition.

There were, however, to be indirect preferences for Great Britain. "In the imposition of the duties we are now about to ask the House to impose," said Tilley, in explaining how the schedules were to favour Great Britain, "it may be said that we will receive from the imports from foreign countries a larger portion of the two. million dollars we require than we shall receive from the Mothercountry. I believe such will be the effect; but I think that in making such a statement to this House, belonging as we do and forming part of that great country-a country that receives our natural products without any taxation, everything we have to send her-apart from our national feelings, I think this House will not object if in the propositions before me they touch more heavily upon imports from foreign countries than from our Father-land." Even with this zealous care for British interests the Minister of Finance was confident that his tariff "would give ample protection to all who are seeking it, and who have a right to expect it."

How the tariff would protect Canadian manufacturers from American competition and not press too hardly on imports from Great Britain, was explained when Tilley came to deal with the-cotton schedules. At this time 
CH.

there was a cotton-mill at St. John, New Brunswick. There was also some cottonmanufacturing at St. Catherine's, Ontario; but as late as 1882 there were only 180,000 cotton-spindles in New Brunswick and Ontario -the provinces to which up to that time the industry was confined." "The principle the Government had adopted with many articles," said Tilley in reference to the cotton-schedules, "is this, that where there are certain goods or descriptions of manufactures, the Government has selected for a higher rate of duty those grades that are manufactured or can be manufactured in the country, leaving those that are not made in Canada, or likely to be made here, such as printed cottons, at a lower rate."

No concealment was made of the fact that it was the policy of the Macdonald Government again to corall the consumers of Canada for the gain of the mining industry of Nova Scotia. The coal duty of 1870 was reimposed. Even anthracite was again included, although there is no Canadian anthracite available east of British Columbia. Tilley frankly told the House that the duty of fifty cents a ton on bituminous and anthracite coal and on coke was intended to give a market to the Nova Scotia mines; and he added that the Government were confident that Nova Scotia bituminous coal could be made to take the place of anthracite. Not less than twelve tons of

1 Cf. Tilley's Budget Speech, House of Commons Debates, February 24, 1882. 
anthracite are necessary for the winter heating of a house in Montreal or Toronto, such as in any English city would rent for thirty or forty pounds a year; so that by the coal-schedule of the tariff of 1879 tribute, averaging six dollars a year, was levied on every householder in the cities of Quebec and Ontario, whether he used Pennsylvania anthracite or Nova Scotia coal, solely in the interest of the mineowners of Nova Scotia.

Another industry that was the special and particular care of the Macdonald Government in the tariff of 1879 was the manufacture of cheap clocks at Hamilton. Tilley's statement in justification of a duty of thirty-five per cent on all clocks to protect a seventy-cent clock concern at Hamilton is typical of much that has characterised protective legislation at Ottawa in the last twenty-eight years. It is even more significant to-day, when there is in England a political party that professes to believe that Canadian tariffs can be arranged in the interest of British manufacturers, than it was in 1879 ; for the policy that was then adopted as regards small industries has been continued ever since, by Liberal as well as by Conservative Governments. The same policy was followed in many instances in the tariff revision of 1907 ; notably in the case of a jewelry factory at Toronto, a distiller of peppermint at Windsor, Ontario, and in the case of a little group of quarry-owners at St. George, New Brunswick. 
CH.

The plea of the clockmaker at Hamilton was that he could not compete with the clockmakers of Connecticut-with the factories in the Naugatuck Valley that supply half the world with cheap clocks. "I was under the impression," said Tilley, when he asked the House to bestow largesse on the clockman at Hamilton, "that clocks were an article on which it would not be wise to impose a duty, as with any protection we might give them we could not compete successfully with our American neighbours. But I found in that busy city of Hamilton, which is represented by nearly every article in the schedules before me, there is a clock-making industry successfully established, and producing a very nice article, in a bird's-eye maple frame, for seventy cents; and they have orders from England for six or seven thousand of these clocks."

The significance to-day of the episode of the seventy-cent clock, in its bird's-eye maple frame, is that it shows that even if it were possible-after England had abandoned free trade to set up preferences for the Coloniesso to frame a Canadian tariff as to give an advantage to a few British manufacturers, not one of the manufacturers could have any guarantee or feeling of security that the concession made to his industry in one tariff would not be withdrawn in the next. Time and again, when the tariff of 1907 was in committee, Mr. Fielding explained the increase in duty on some article by remarking that 
it was an article now made in Canada. It must also never be forgotten in England that Canadian manufacturers are adepts at clothing self-seeking in the fine garments of love of country and love of empire. They are adepts at making a vast system of social demoralisation and political corruption wear an altruistic aspect-adepts at all the little artifices of commercialised patriotism. They will cover half the letters that go through the post office with pasters which read, "When you can't get what you want at home, buy within the British Empire" ; and, as was the case when the Tariff Commission was at the cotton manufacturing town of Valleyfield, Quebec, ${ }^{1}$ they will run up the Union Jack on the flag-poles of their factories, and go before the Commission with a plea for an increased duty on cotton goods from Lancashire on the ground that Manchester exporters are as much given to end-of-theseason dumping as those at Fall River or Lowell.

There was one solitary modern blast-furnace in Canada in 1879. It was in Nova Scotiaat Londonderry - and like the coalmen of Cape Breton and Pictou and Cumberland counties, the men who were interested in it had a political pull, and the Londonderry furnace was duly cared for in the tariff. "In dealing with this question," said Tilley, when he came to the iron-schedules, "the Government have to take into consideration the important iron

1 On December 26, 1905. 
industry of the Dominion. It is quite true that a very large deposit of iron is found in the province of Nova Scotia. Adjacent to it are immense beds of coal; and no doubt for the province of Nova Scotia this interest is a very important one. But it is not confined to Nova Scotia. We find on examining the geological reports, and the reports of the officials who have been charged with inquiring into the extent of our iron deposits, that in every province of the Dominion there are large deposits of iron. From the west we have had specimens of iron submitted to us of the most valuable character, made by the application of heat from petroleum, which appears to remove some of the difficulties that have been experienced in producing good iron before, inasmuch as it removes the phosphorus and sulphur which rendered to a great extent that iron valueless. If this be so, we may reasonably expect that in the western part of our Dominion, in Nova Scotia, in the valley of the Ottawa, in the provinces of Quebec and New Brunswick, we may, by giving some encouragement to this manufacture or its production, have these interests springing up all over the Dominion, and producing the most beneficial results. It may safely be said that the iron industry is at the basis of every other industry. It is true that we have not developed it to a great extent yet. We have one establishment at present in operation in Nova Scotia. It can produce only one-fourth 
of our present consumption; but there is no reason why we should not secure the whole of the trade in time." 1

To this end a duty of two dollars a ton was imposed on pig-iron; two dollars a ton on scrap-iron; twelve-and-a-half per cent on slabs, blooms, billets, and puddled iron bars; and seventeen-and-a-half per cent on merchantiron-all in the interest of the furnace at Londonderry which two years later was in the bankruptcy court. At this juncture the Macdonald Government again went to its aid; and in 1883 there was begun on its behalf the system under which at the present time bounties to the amount of over two million dollars a year are bestowed from the Dominion Treasury on the iron and steel industry. ${ }^{2}$

House of Commons procedure and usages at Ottawa follow those of Westminster in every detail. Any man accustomed to the House at Westminster is at home as soon as he enters the stately chamber of the Commons of Canada. It is the usage that the exMinister of Finance shall open the debate on the budget. Sir R. Cartwright was accordingly the first member of the Opposition to criticise the tariff policy which Tilley had expounded. No man who has ever been in Canadian political life has brought into the

1 House of Commons Debates, March 14, 1879.

2 For the three months ending March 31, 1907, the bounties were $\$ 534,314$. 
CH.

public service a mental equipment equal to that of Sir Richard Cartwright. In intellect and grasp of political policies and questions, and in ability to give utterance to his convictions, Sir Richard, for more than a quarter of a century, has towered above all his fellows at Ottawa. He has lacked the moral fibre of Gladstone or Bright; but had he been of the House of Commons at Westminster, he might have ranked with either as a Parliamentary debater or as an orator in the constituencies. He never led the House of Commons; but from 1879 to 1896 he was in the centre of the fight, and he was pre-eminently the mainstay of Liberalism and of free trade in the Dominion of Canada. In these years his hold on the House of Commons and on the Liberal party in Canada was as close and as continuous as the hold which Gladstone and Bright had on Parliament and on the constituencies of England. There were three leaders during the seventeen years when the Liberals were in Opposition-during the long period when they were persistently waging war on the National Policy. Mackenzie, Blake, and Laurier in turn led the Liberal Opposition; but throughout this long period of discouragement the name most closely associated with Liberalism, and with unequivocal and uncompromising opposition to protection and the political corruption it engendered, was that of Sir Richard Cartwright. 
In all these years Sir R. Cartwright was the man of greatest capacity in Dominion politics. His knowledge of other countries - their history, their politics, their fiscal systems, their industrial economy and their social life -and in particular of England and the United States, far excelled that of any of his compatriots in Canadian politics. His outlook in these years, before in 1897 he turned his back on his past, was larger and less provincial, his influence on political thought in Canada was wider and more far-reaching than that of any of his contemporaries. Sir W. Laurier is an orator; but no one who did not hear Sir R. Cartwright in his opposition days can ever realise the high level reached at times by debate in the House of Commons.

Presence, voice, earnestness, strong convictions, and ideas popularly expounded,all combined to make Sir Richard Cartwright an orator of first rank. At Westminster, and in the more favourable atmosphere and environment of English politics, he would have ranked as a statesman. Had he taken an independent line after the Liberal success at the general election in 1896-had he kept in mind his past utterances, his past services to the cause of free trade and clean politics, and the reliance of tens of thousands of Liberals all over Canada on his political record up to 1896-had he even retired from political life rather than be an assenting party to the great betrayal of 1897, Sir Richard 
would to-day rank among the statesmen of the British Empire, and his speeches would be political classics read to advantage beyond the boundaries of the Dominion.

Sir R. Cartwright's criticism of the National Policy tariff of 1879 is one of the most effective speeches of his long House of Commons career. Even to-day, nearly thirty years after it was uttered, it ranks as a great indictment of the protective system. It was especially applicable to Canadian conditions when the Dominion was at the parting of the ways. But as a general indictment of the social wrong and injustice, and of the political dangers to democracy and representative institutions all inherent in a system for enabling industry to lean on the politician, and to pay in meal or malt for the privilege, it must long have a prominent place in the literature of the protectionist controversy.

Since 1879 phases of protection have developed in Canada, evils have arisen out of the system, which Sir R. Cartwright could not treat in his condemnation of the first National Policy tariff. Political corruption; the brazenness and moral squalor of the Red Parlour; the more widespread squalor that resulted therefrom in the constituencies $;^{1}$ and the callous indifference of a well-to-do, intelligent, active, and socially influential section of the com-

1 Cf. Goldwin Smith, Canada and the Canadian Question, pp. 224, 225; Laurier's and Cartwright's speeches at the National Liberal Cunvention in 1893, Official Report, pp. 38, 42, 43. 
munity to any and all evils or injustices in the political life of the Dominion, so long as they are able to use the politicians in power for their personal gain, did not begin to develop until the system adopted in 1879 had been tried. As soon as these developments were obvious, and these political and social dangers came into view, Sir R. Cartwright fearlessly exposed them, and brought into light the men who were responsible for them. This he frequently did in the House of Commons between 1879 and 1896; and he did it, moreover, as was characteristic of him in his opposition days, when the men whom he held directly responsible for the evil were confronting him on the Treasury Bench. ${ }^{1}$

In $1879 \mathrm{Sir}$ R. Cartwright could only predict the evils that would result from the adoption of a protective system in Canada; and to do this he drew on his wide knowledge of the working of the system in the United States. "My objection to this scheme," he said, enunciating first his general argument against protection, "goes deep. I object to it not merely on the ground of the increase of taxes that it involves, or of its complicated details, but on much higher ground than that. I deny entirely the justice of the course which the majority of the House appear, I fear, determined to follow. I admit their power; but I deny their right. I say that the principle which I have heard

1 Cf. House of Commons Debates, April 11, 1890, and March 12, 1892. 
enunciated by the Minister of Finance-the principle that it is the duty of the Government to enable certain sections of the community to tax the rest of the people for their private gain-is of all others the principle which a free people should least submit themselves to. I say that it is the very essence of all injustice. I say that the Government could not be fair in the application of such a principle, no matter how earnestly they might try. And I tell the honourable gentleman that when he says that by any adjustment of the tariff it is possible for him, or for any government that ever existed, to protect, by additional taxation, men who find the market for their productions in other countries, he commits himself to a palpable absurdity. This special legislation, such as we have now got to deal with, is inconceivably bad. It is the very thing which every free country has always fought against. I say that you are committing a gross retrogression. You are going back for centuries. It is practically a revolution."

"In times gone by," continued Sir R. Cartwright, coming to close range with the new tariff, "in the early part of the present century, the Government of the United States saw fit to introduce a tariff somewhat similar to this. That tariff is familiar to students of American history as the tariff of abominations. ${ }^{1}$ I do

1 The tariff of 1828, described in Stanwood, American Tariff Controversies of the Nineteenth Century, i. pp. 243-290. 
not know that this tariff rises to the dignity of the American tariff I have named; but the Canadian student may perhaps describe it as a tariff of corners. There is scarcely a single proposal in which men accustomed to deal with such questions will fail to see concessions to some particular clique, to some particular interest, to some prominent political partisan, or to some particular class, whom it is desirable for political reasons to conciliate. How, or in what manner, that tariff has been evolved from the mind of the presiding genius, it might be impertinent in me to speculate. You have admissions here, concessions there, and injustice everywhere. The honourable gentleman appears in framing the tariff, according to his own confession, to have adopted a plan somewhat similar to what Carlyle declares to be the impossible problem -namely, out of the united action of a community of dishonest men to evolve an honest principle. I should say that the principle predominant in the mind of the honourable gentleman has been, "Get influence-revenue if you can, but political influence anyhow."

Sir Richard Cartwright made one prediction that did not come true-a prediction to the falsification of which he was himself a party, when the Laurier Government revised the tariff in 1897. He declared that the people of Canada would never permit the manufacturers to claim a vested interest in a National Policy tariff when the Conservative Goverument should be over- 
thrown. The overthrow was longer in coming than he and his colleagues of the Opposition anticipated, in 1879. But it did come; and the vested interest of the manufacturers in protection was duly recognised and respected by the newly-elected Government, in spite of hundreds of speeches, in and out of Parliament, by leaders of the Liberal party between 1879 and 1896, as strongly condemning protection as the speech which Sir R. Cartwright made in the House of Commons after Tilley had enunciated the National Policy of the Macdonald Government. ${ }^{1}$

In 1879, however, Sir Richard Cartwright was convinced that the people of Canada, when they were weary of National Policy governments, would never recognise any such claim. "Nor can the manufacturers with any degree of justice," he asserted, "raise the plea of vested interests which has often been used to prevent alterations in the tariff as it stood. Where men have created a business under the operation of a tariff passed for the purpose of promoting the welfare of the whole people, I admit a great deal may be said against any violent alteration or inter-

1 At Chatham, Ontario, November 23, 1905, an outspoken Liberal of the old school demanded of the Tariff Commission why the Liberal Government had abandoned their ideas concerning a tariff for revenue only. In reply, Mr. Paterson excused the Liberals for not having overturned the protective policy of the Macdonald Government. "Violent changes which involve the closing of manufactories and the throwing out of hundreds of thousands of workpeople," said Mr. Paterson, "are changes that no men charged with the responsibility of government dare to face."-Boston Tran. script, November 23, 1905. 
ference with what has been the settled policy of the country. But when men deliberately sell themselves to this or that political party for the avowed purpose of taxing the rest of the community for their private benefit, there are no vested rights in such a case, though there may be vested wrongs enough for the people when they come to their senses to redress."

The traffic that Sir R. Cartwright describedcampaign contributions in return for statutory rights to make the consumer pay the manufacturer's price, or in later days the price dictated by a trust-went on as long as Conservative Governments were in power. Both Sir R. Cartwright and Sir W. Laurier spoke of the prevalence of the traffic, and denounced it, as late in the era of the National Policy of the Conservatives as the Liberal Convention of $1893 .^{1}$ But in 1897, after the Liberal party had been returned to power, the manufacturers and, in their train, the bankers and financiers of Montreal and Toronto who had loaned them money, were soon at Ottawa, with just such a plea as Sir Richard Cartwright in 1879 had declared would be repudiated; and ten years more of protection, differentiated from the protection of $1879-97$ by little more than the preference for British imports-a preference that brings but small and sporadic relief to the general body of consumers-has been the result of the people of Canada having,

${ }^{1}$ Cf. Official Report of National Liberal Convention, pp. 36, 43, 44,71 . 
$\mathrm{CH}$.

in 1896 , to use Sir Richard's expression, "come to their senses."

Other of Sir R. Cartwright's predictions have come true enough. " "Looked at in its financial aspect," he said of the tariff of 1879 , "it means this. For every dollar you put into the national treasury you are going to take four from the pockets of the people, possibly even more." "Socially," he continued, "I do not conceive it possible to imagine a policy which is likely to do more to corrupt the people of Canada than that brought down to-night. You are deliberately introducing a system which recognises the leading ideas of socialism ; which indeed practically justifies the leading tenet of socialism-that property is theft; for assuredly property acquired in this way, under a tariff such as this, is very little better than downright legalised robbery."

Sir R. Cartwright then described the men who would avail themselves of the political opportunities for legalised robbery. "There are," he said, "able and unscrupulous men who know that under such a system the short-cut to wealth is best obtained by securing political influence enough to get the tariff fixed to their own ends. You offer a premium to these men in every possible way to corrupt the Legislature; and if the example of the United States can be relied upon, you may rest assured your labours will not be in vain." "Knowing, as we do, from dearly bought experience," he said, in finally emphasising 
the imminent danger to representative institutions in Canada, and with the gross scandal of 1873 in mind, "how grievously this Legislature and our Provincial Legislature have suffered in times gone by from improper influences brought to bear upon them by wealthy and powerful corporations, or even by wealthy and powerful individuals, we find the Government deliberately making it the interest of the wealthiest and most active classes of the community to obtain, anyhow and by any means whatever, power over the legislature of the country."

Almost every argument that during the ensuing seventeen years was used against the National Policy by the Liberals was advanced during the debate on the Tilley tariff of 1879 . Its unfairness to the labouring classes; the fact that the amount of protection afforded manufacturers was much in excess of that set out in the tariff schedules; its encouragement of trusts and combines; the unfairness of the incidence of the duty on coal ; the injustice to the Maritime Provinces, which had little manufacturing; and the hostility to Great Britain that was characteristic of the tariff-all these arguments were put before the House of Commons by the Opposition before the schedules were approved and the tariff was sent to the Senate.

The most cogent argument was that the tariff would work injustice to the labouring population of the Dominion in consequence of the

1 House of Commons Debates, March 14, 1879. 
method of adjusting the schedules; and because, while protection was afforded to the manufacturers, there could be no protection to the wage-earners so long as it was the policy of the Government to continue an active immigration propaganda. It was urged that by imposing high duties on the cheaper grades of manufactures, especially of cottons and woollens, and lower duties on the more expensive descriptions imported from England, a gross injustice was done the working classes, who were necessarily the purchasers of the cheaper textiles.

The objection that there could be no protection of the wage-earners-no protection of the labour they had to sell-as long as the Government was spending hundreds of thousands of dollars every year in inducing immigration to Canada, was pressed by Mr. Charlton of Ontario. It is an objection that has remained good ever since, and that has never been met by either Conservative or Liberal governments. It applies with as much force to-day against the Fielding tariff of 1907 as it did against the National Policy tariff of 1879. It is true that the Dominion Government no longer gives assisted passages to immigrants, as was done for many years by the Conservative governments. But Canada is now spending between seven and eight hundred thousand dollars a year on its immigration propaganda ; and the newspapers which support the present protective tariff jubilantly note the ever-rising tide of immigration from the United Kingdom 
and from every country of Europe in which Canadian emigration agents are permitted to carry on their work.

The Canadian policy of protection in this important respect has been widely different from that of the United States. I am no admirer of protection, whether it be embodied in the National Policy tariffs of Canada, or in the M'Kinley or Dingley Acts. But it must be acknowledged that there has been an effort towards fairness and consistency in the protectionist policy of the United States which has been flagrantly lacking in Canada. The Government at Washington never spent a cent in encouraging immigration. Until 1875 all comers were welcome to the United States, and no questions were asked by Federal officers at the ports. But since 1882 the Government at Washington, in order to be consistent in its protective policy, has gradually made the laws governing the admission of immigrants more stringent. These laws are strictly enforced; more uniformly enforced than any other laws on the Federal statute book. A landing fee of four dollars is now exacted from every immigrant; an immigrant must be possessed of not less than thirty dollars; and, moreover, since 1885 admission has been denied to men and women who have made contracts abroad, written or implied, to labour in the United States. ${ }^{1}$

1 Cf. Porritt, American Immigration Laws, Co-operative Annual (Manchester), 1894, pp. 171-197. 
Except for the enactments to restrict immigration from China, and to exclude physical and moral undesirables, Canada cannot, with her long maintained immigration -policy, have any such laws for the restriction of immigration as those of the United States. ${ }^{1}$ The Dominion Government have never attempted to make their protectionist policy consistent. They have been content if the National Policy served the ends of the manufacturers. They have never looked beyond, nor sought direct approval outside the ranks of these politicians of business. The trade unions since 1896 have held the Laurier Government to a pledge not to direct immigration propaganda towards skilled labour from the United Kingdom. The Government have lived up to this pledge, ${ }^{2}$ in spite of much pressure from the Manufacturers' Association, which for years has insisted that it is the business of the Government not only

1 The kind this city is receiving-without solicitation-is made up largely of large families, with a London education that is deficient, and which shows its quality in careless and indifferent lives. Some of them-men, women, and children-have been seen sitting about the highways, and at the railway stations, having no funds, no plans, and no ambitions. Their destination was Kingston, but why they could not say. The result is a filling up of shacks with an unfortunate class, who are already dependent on others for a livelihood, and whose whole support will become necessary as the winter season approaches.-Whig, Kingston, Ontario, June $29,1907$.

2 "It is a mild restriction, for it leaves the workmen exposed to the open and free competition of all the foreign labour that comes voluntarily to the Dominion, and this is encouraged by a generally active immigration policy. If the employers would accept this compensatory restriction, and show a willingness to allow their workmen to participate in the favours conferred by the fiscal policy, they would remove one of the most persistent sources of attack on their privileges."-Editorial article, Globe, July 4, 1907. 
to enclose the consumers of the Dominion in a stockade, so that they shall have no option but to buy their goods, but also to recruit labour from oversea for Canadian factories. ${ }^{1}$

There is a law that prevents Canadian employers from making contracts with men in the United States to work in Canada. It is, however, only spasmodically enforced; and any drastic enforcement of it, such as the enforcement of the Alien Contract Labour Laws of the United States, would cripple the shipbuilding plants on the Great Lakes and half the iron and steel plants of the Dominion, for most of the skilled men in these departments of the iron and steel industry are recruited from the United States. There is, however, no law to prevent Canadian employers from making contracts with men in the United Kingdom; and since the end of 1906 the Manufacturers' Association has maintained a labour bureau in London to recruit men for work in Canadian factories. ${ }^{2}$ Hence, whenever there is a strike it is always possible, as it was when the longshoremen at Montreal went out in May 1907, for the

1 "Resolved that the Dominion Government be respectfully urged to encourage through its present immigration officers and by the appointment of special representatives for this purpose, the immigration not only of farn-labourers, but also of skilled mechanics, where opportunities are known to exist, and thus assist in building up our national industries."-Report of regular monthly meeting of executive council of Canadian Manufacturers' Association, held at Toronto, May 16, 1907-Industrial Canada, June 1907,895 .

2 Cf. Reports of Annual Convention, Canadian Manufacturers' Association, Winnipeg, September 23, 24, 1906, and Toronto, September $24-26$; 1907. 


\section{PROTECTION IN CANADA сн.}

employers to threaten that they will import men from the Old Country. ${ }^{1}$

Labour has been in this position ever since the National Policy was inaugurated in 1879. This was admitted by so stalwart a supporter of the Liberal Government as the Globe, as recently as July 4, 1907. "The wage-earner," said the Globe, in discussing the appeal of the Manufacturers' Association to the Government, that the Government immigration agents in England should be instructed to recruit skilled labour for the factories, "is among those who lose by the protective system. Its first effect is to increase the cost of all his domestic and personal supplies. He buys goods and sells labour; and even the articles made by his own hands must be bought at a price enhanced by the tariff." 2 Wages are regulated by the number of men and women at the door of the factory, not, as the employees of the Dominion Steel Company at Sydney, Cape Breton, realised after an unsuccessful strike against a reduction of wages in 1903 , by the bounties or the protective duty on the output.

1 In an interview with Mr. Robert Reford, the Globe representative was treated to some terse comments on the situation. Mrr. Reford was in a fighting humour, and was not disposed to yield a point. "We are paying them good wages," he said. "These men are earning 25 and 30 cents an hour; and $\$ 2.50$ to $\$ 3$ a day is good money for unskilled labour. [Longshore work seldom lasts for more than seven months out of the twelve at Montreal.] We cannot afford to pay more and will not do it. If things are not settled in two days we will cable to our British representatives and get them to send out shiploads of men. There are plenty over there who would be glad to come. No, we will not yield. We defeated them before, and we will again."-Globe, May 15, 1907.

${ }^{2}$ Cf. Globe, editorial page, July 4 and September 30, 1907. 
The pretence that the tariff protects labour is as transparent as the claim that it is of advantage to the grain-grower or the stockraiser who must find a market in Liverpool, London, or Glasgow. The tariff ever since 1879 has worked all the injustice to the wage-earning classes predicted by Mr. John Charlton; for the wage-earner not only must pay enhanced prices for most of the articles he needs, but he must pay his quota to the immense sum which the Government is spending each year in inducing men to come into Canada to compete with him for work.

Mr. Charlton's speech was one of the most practical contributions to the debate on the tariff of 1879. It is the speech of a man familiar with the details of business rather than that of a politician. It was practical from beginning to end, and nowhere more practical than in the quotation of figures to show that the actual cost of protection to the consumer cannot be measured only by the tariff schedules.

In estimating what the duties of the tariff of 1879 would mean to Canadian consumers, Mr. Charlton took no account of transport charges, and the natural protection which these afford Canadian manufacturers against oversea competition. He confined himself to the profits on imported goods charged by jobbers, wholesalers, and retailers, and showed what the tariff meant to consumers when duties had to be paid by them on these two sets of profits. 
"If a duty of 20 per cent," he said, " is imposed on an article, the wholesale merchant places a profit of, say, 10 per cent on the original cost and on the duty as well. The retail merchant imposes his profit, which is, say, 25 per cent on the original cost and on the duty and profit of the wholesaler. An article that pays 20 per cent duty thus costs the consumer, as a consequence of the duty, $27 \frac{1}{2}$ per cent on the original cost; if the duty is 25 per cent, it costs the consumer $34 \frac{3}{8}$ per cent advance on the original cost; if the duty be 30 per cent, it costs the consumer $41 \frac{1}{4}$ per cent in advance of the original costs; if the duty is 35 per cent, it costs the consumer $48 \frac{1}{8}$ per cent of its original cost; while if the duty is 40 per cent, it costs the consumer 55 per cent in advance of its original cost." 1

Mr. Charlton's explanation of what tariff duties mean to the consumer was a statement of a general principle-a principle that must apply in all countries in which there are protective tariffs. It is as applicable to-day as it was in 1879 ; but while much stress was laid upon the principle by the Liberals in opposition, it was as completely ignored by Liberal governments when they revised the tariff in 1897 and 1907 as it was by Tilley and the manufacturers whom he called into council to help in the framing of the tariff of 1879.

Even before National Policy tariffs were

1 House of Commons Debates, March 18, 1879. 
enacted, Canada had had some experience of a combine. Oil-refining in Ontario, which was protected by tariffs of an earlier date than 1879 , was controlled by a ring at least as early as $1878 .{ }^{1}$ It was the first Canadian industry producing an article of general use that was controlled by what to-day would be called a trust. Mr. Charlton was more confident than any other opponent of the tariff of 1879 that protection must bring other trusts into existence; and no prophecy concerning National Policy tariffs has been more true. $\mathrm{He}$ cautioned the House that the monopolies the tariff would bring into existence would not be easily broken up. He predicted that it would take more than one verdict of the people-more than one Dominion electionto loosen the grip of death-like tenacity which monopolies would fasten on the people of Canada.

Combines and trusts soon developed; and since Mr. Charlton's warning three enactments have been passed by the Dominion Parliament ostensibly to check the rapacity of trusts. $^{2}$ There have also been six general elections, ${ }^{3}$ with the overthrow in 1896 of the original National Policy party; but to-day the trust more generally and more securely controls trade in the Dominion than ever before. The trust has freer play and a better field for

1 House of Commons Debates, February 26, 1878.

2 In 1889, 1897, and 1907.

$31882,1887,1891,1896,1900$, and 1904. 


\section{PROTECTION IN CANADA сн.}

operation in Canada than in the United States, where it first came into existence; and there can be no dislodgment of it, nor any effective and general check on its rapacity, so long as the protective tariff is on the statute book, and there continues the community of interest between the politicians of business and the politicians at Ottawa that can be dated back to Macdonald's notorious offer to the manufacturers at Hamilton in 1878.

Cotton-manufacturing was the first large industry in which after the tariff of 1879 a combination was formed to keep up prices. In 1884, when the tariff was again under revision and the cotton schedules were made much more comprehensive than in the tariff of 1879, Mr. Paterson objected to any increased protection for an industry which was paying dividends at the rate of thirty per cent. ${ }^{1}$ Two years later, in August 1886, the cotton manufacturers met in Montreal, effected a complete union, and arrived at an agreement to advance prices. ${ }^{2}$ But cotton-manufacturing was not for long the only industry that was thus controlled. All kinds of industries, large and small, were soon organised in much the same way and to much the same end; and by 1888 these combinations were so numerous, so aggressive, and so open in their buccaneering, that there were complaints in Parliament of the extent to which consumers were "held up" or

1 Cf. Dominion Annual Register, 1884, p. 44.

2 Dominion Annual Register, 1886, p. 314. 
victimised by them. "In Montreal," said a member of the Liberal Opposition who drew attention to the new development and to its connection with the tariff, "we have a cotton combine, a flour combine, a sugar combine, a rubber combine, a stovemakers' combine, and an undertakers' combine. Some of these combines may make claims for services which they have rendered to the Government within the last two years, and the Government may be hampered in dealing with their claims by an absolute statement that there are to be no changes in the tariff." 1

The new development aroused much uneasiness all over the Dominion. To allay it there was an investigation by Royal Commission in the winter of 1888-89. A combine was unearthed among the coal-dealers of Ottawa and Toronto, one of the features of which was the sale by auction of the privilege of tendering without bona fide competition for the supply of coal to the Governments of the Dominion and the Province of Ontario, and to other public or semi-public authorities. A gentlemen's agreement was also ascertained to exist between the tariff-protected sugar-refiners and the Wholesale Grocers' Guild, the purpose of which was to put out of business wholesalers who were not of the guild. Combines were also found to exist in the binder-twine industry; in the salt industry in Ontario, which had been protected since 1870; and also among the

1 House of Commons Debates, February 28, 1888. 
owners of factories at Hamilton and Three Rivers at which coffins were made.

In extenuation of the protective system it was pleaded for the Government that very few of these rapacious organisations were due to the National Policy. But at this time the Liberal Opposition was strong and alert, and well supported by the Liberal press. 'To offset the new agitation against the tariff an Act was passed by the Macdonald Government for the suppression of combinations in restraint of trade. There could have been no sincerity in this action of the Government. 'The Act ${ }^{1}$ is so innocuous that it might have been drafted by a lawyer for the trusts. It was so worded that its uselessness was stamped on its face. It was a clear case of humbugging the people; as glaring an instance of such tactics on the part of politicians as is to be found anywhere in the statute books. Obviously the politicians responsible for the Act of 1889-this Act to punish organisations which unduly prevented or lessened competition in trade-was never intended to be anything more than a make-believe; for there could be no conceivable use in manufacturers dickering with the politicians of the Red Parlour for high protective duties, and running to Ottawa to see that Red Parlour bargains were made good, if there were a law to prevent the manufacturers combining among themselves to obtain the fullest advantage from the statutory 
privileges which they had bought from the politicians.

No combinations were broken up by the Act of 1889 ; and in 1897, when the newlyelected Liberal Government was disposed to adhere in some trifling respects to the tariff policy it had so long and so persistently advocated in opposition, a new clause was introduced into the tariff. It reads :-

Whenever the Governor in Council has reason to believe that with regard to any article of commerce there exists any trust, combination, association or agreement of any kind among manufacturers of such article or dealers therein to unduly enhance the price of such articles, or in any other way to unduly promote the advantage of the manufacturers or dealers at the expense of the consumers, the Governor in Council may commission or empower any judge of the Supreme Court or Exchequer Court of Canada, or of any superior court in any province of Canada, to inquire in a summary way into and report to the Governor in Council whether such trust, combination, association or agreement exists.

If the judge reports that such trust or combination, association, or agreement exists, and if it appears to the Governor in Council that such disadvantage to the consumers is facilitated by the duties of customs imposed on a like article when imported, then the Governor in Council shall place such article on the free list, or so reduce the duty on it as to give to the public the benefit of reasonable competition in such article. ${ }^{1}$

The Conservatives were in opposition when the tariff of 1897 was before the House of Commons, and they strongly opposed the new clause. Sir C. Tupper declared that it would

1 60-61 Vict. c. 16 , s. 18. 
make the innocent suffer with the guilty; that it gave the Government power to tyrannise over manufacturers; and that it was legislation of the most vicious character. It was suggested that there should be compensation from the Dominion Treasury for any one not in a combine who might suffer by any article he made being put on the free list. Another objection from the Opposition was that action by the Governor in Council in such a matter as this was to be deprecated, and that Parliament only should have the power of putting an article on the free list or reducing the duty when a combine had been ascertained to exist. ${ }^{1}$

The opposition and alarm on the part of the Conservatives was needless. The Laurier Government in 1897 had no intention of seriously assailing the trusts. They added the clause to the tariff, but they made no provision for its enforcement by any officer of the Dominion Government. Its enforcement, with the attendant legal expenses, was left to the common informer. The result has been that although the clause has now been on the statute book for ten years, only in one solitary instance has a duty in the tariff been reduced by order in council under its provisions.

Paper-making in Canada has been protected since 1859. The duty on news printing-paper in the tariff of 1894 was twenty-five per cent. In the first Liberal tariff-that of 1897-this

1 House of Commons Debates, April 22, 1897. 
duty was continued; and in 1901 the Press Association of Canada, an organisation of newspaper publishers, realised that behind this duty a trust was entrenched which was charging them for news printing-paper prices from forty-five to fifty cents a hundred pounds more than newspaper publishers were paying in the United States for the same quality of paper, in spite of the fact that many of the paper-mills of the United States import their supplies of pulpwood from Canada. Affidavits setting out these facts were submitted to the Government. An order in council was issued directing Mr. Justice Taschereau to sit as a Royal Commission and hold an inquiry; and after the Press Association had spent eighteen hundred dollars in substantiating its charge, the duty on paper was reduced from twentyfive to fifteen per cent. ${ }^{1}$ Thus the only trust ever brought to terms under legislation enacted by the Dominion Parliament was the one that had had the audacity to flaunt its contempt for the anti-trust legislation of 1897 in the face of the newspaper publishers of Canada.

Only an organisation such as the Press Association dare venture to invoke the law. Ordinary consumers-the men and women of Canada who are unorganised, and who can never make their protests of avail when the tariff is being revised-cannot hope for any

1 Cf. Canadian Newspaper Publishers and the Papermakers Trust, Sell's Dictionary of the World's Press, 1902, 120, 121. 
relief from the anti-trust clause. The manufacturers pay no heed to it. Scores of them admitted to the Tariff Commission of 1905-6 that they were of these combinations, but asserted that they did not unduly raise prices, and the Tariff Commissioners took them at their word. Moreover, the Minister of Public Works in the Laurier Cabinet when the tariff was revised in 1906-7-Mr. Hyman of Ontario -was at the time a prominent member of the tanners' trust, a trust that not only determines the prices at which leather shall be sold, but also the prices that shall be paid to Canadian lumbermen for tan bark.

The attitude of manufacturers generally towards the clause-their conviction that it was not intended to interfere with their schemes-is exemplified by the fact that in November 1906 nearly forty trusts were exposed at Toronto by the Crown Prosecutor of Ontario, acting under a provincial law, of which only two or three could have existed a month without the protective duties in the tariff of 1897 . Their attitude may also be judged from an announcement on November 30,1906-the day after Mr. Fielding had submitted the new tariff to the House of Commons-that a holding company-an American device for trust organisation and stock manipulation-capitalised at seven and a half million dollars, had been formed in Montreal to control the manufacture and sale of rubber goods in the Dominion, on which the duties in the general 
tariff are from twenty-five to thirty-five per cent. $^{1}$

Three companies with headquarters in Montreal control the cotton mills in New Brunswick, Quebec, and most of those in Ontario, on the output of which there are duties in the general tariff ranging from twentyfive to thirty-two-and-a-half per cent. This control is considered so much a matter of course that in the Canadian Trade Index-the official annual publication of the Canadian Manufacturers' Association-it is announced that "the cotton industry is in the hands of very strong mills"; while for Canadians who are paying these duties on their cottons, there is the compensating information that these cotton companies, which would have it believed that they could not thrive without high protective duties, exported half a million dollars' worth of cottons in 1900, and that "the export trade promises to develop even more rapidly with the advancing facilities for communication with the Orient, as Canada is so favourably situated for the supply of goods to the East." 2

At Toronto in 1905 the Canadian Press Association strongly pressed the Tariff Com-

1 Cf. Witness, Montreal, November 30, 1906, also editorial article on Rubber Merger, Globe, June 26, 1907, in which it was stated that "The Canadian Consolidated Rubber Company, which has virtually a monopoly of the rubber manufactures of the Dominion, has become annexed to, or amalgamated with the United States Rubber Company, a concern holding a monopoly on the other side of the line."

2 Canadian Trade Index, 1900, p. 16. 
mission to amend the anti-trust clause so as to make its enforcement the duty of an executive officer of the Dominion Government. Stress was laid on the fact that it had cost the Association eighteen hundred dollars to proceed against the paper trust in 1901 ; and also on the fact that at Washington there is a state department charged with the administration of the Federal anti-trust laws. But all the concession that was made in response to this appeal was an amendment to the clause making proof in any court of record of the existence of a trust, which unduly promotes the advantage of manufacturers or dealers at the expense of consumers, ground for the removal or reduction of duties by order in council. ${ }^{1}$ The concession was small; but in cases like those which were in the courts in Toronto in 1905 it would give some relief; for with proof of conviction in the assize court it at once becomes possible for the Dominion Government to act without further inquiry. ${ }^{2}$

The trust is an inevitable concomitant of a protective tariff. When once competition from abroad has been restricted by enactment, combination inside the tariff wall is a logical consequence; and the smaller the population the easier it is to bring about combination. Mr. Charlton took no risk as a prophet in 1879

1 Cf. Customs Tariff, 1907 , s. 12.

2 Of the anti-trust prosecutions begun at Toronto in November 1905 , only one has been carried to a final and successful issue. On June 28, 1907, all the other cases-more than thirty of themwere still pending in the courts. Cf. Globe, June 28, 1907. 
when he warned the House of Commons that it would take more than one verdict of the people to break down the combinations in trade that were inherent in the National Policy.

For seventeen years Conservative Governments were responsible for the fiscal policy of the Dominion. The tariff was revised in 1884 , and again in $1894 ;^{1}$ and in the intervals between these revisions, changes, chiefly of a protective tendency, were made when budget legislation was before Parliament. ${ }^{2}$ Occasionally there were changes in a contrary direction, as in 1885 , when coke used by manufacturers was put on the free list, and in 1887, when the duty on anthracite coal was repealed. But throughout the whole of this period manufacturers who could exercise any political influence were usually granted the protection they desired; and in later years, when the tariff was under discussion, the Opposition directed its attacks against the institution now known in Canadian political history as the Red Parlour. In the newspapers and in political literature of a more permanent and responsible character, ${ }^{3}$ there was no beating

1 At one of these revisions the Government summoned a tariff expert from Washington to their aid.-Honse of Commons Debates, April 11, 1890.

2 "Of course," wrote Mr. Goldwin Smith in 1891, "there is continual running to Ottawa for larger draughts of the fatal stimulant, when the first dranght has failed. - Canada and the Canadian Question, p. 209.

3 Cf. Goldwin Smith, Canada and the Canadian Question, pp. 204, 224. 
354 PROTECTION IN CANADA сн.

about the bush in discussing the relations of the protected manufacturers with the Conservative governments. It was again and again affirmed that the manufacturers subsidised the Conservative party; that they paid in this way for having consumers coralled by the tariff, and compelled to buy their wares and pay the prices that they were enabled to exact.

There was a duty in all these National Policy tariffs of one cent a pound on rice in the interest of two mills at which imported paddy rice was cleaned. Sir R. Cartwright once figured out that by this duty $\$ 170,000$ a year was, as he described it, "fraudulently abstracted from the pockets of the people"; and he asserted that of this sum ten or fifteen thousand dollars was turned over at Red Parlour conferences to those who "devised the robbery for the development of the election fund." Sir Mackenzie Bowell, who was at this time Minister of Customs, interjected, "You don't mean that!" "I mean every word of it," answered Sir Richard Cartwright, "and I know how you do it." Sir R. Cartwright further asserted that it was the custom of members of the Cabinet to call manufacturers together and assess them for Conservative campaign funds. Sir M. Bowell's only answer to this amplification of the first charge of corruption was that the statement was unworthy of a gentleman. "I say," was Sir R. Cartwright's retort, "that the 
whole business of protection is robberylegalised robbery; that you subsidise the manufacturers, and that in return the manufacturers subsidise you." 1

On another occasion Sir R. Cartwright made the same charge as specifically as it was made by Mr. Goldwin Smith in 1891, when he published "Canada and the Canadian Question." "The thing," said Sir Richard Cartwright, "is done openly and shamelessly by both parties to the transaction. Prior to the general elections of 1882, 1887, and 1891, Sir John Macdonald and his colleagues called the protected manufacturers together, and demanded and obtained from them such sums as they deemed necessary for debauching the electorate, pledging themselves in return not to alter the tariff to the detriment of the said contributors, which compact was faithfully carried out and impudently avowed." Sir C. Tupper, in the House of Commons, called Sir R. Cartwright's attention to this serious charge. "Every word of it is true," answered Sir R. Cartwright; " and you know it." Sir C. Tupper's defence was brief and significant. "I say," he retorted, "the honourable gentleman cannot prove it. There is no evidence in existence so far as the people in Canada know." ${ }^{2}$

Nor did the Opposition rest content with making these charges. In 1883, when some

1 Cf. House of Commons Debates, April 11, 1890.

2 Honse of Commons Debates, March 22, 1892. 
changes in the tariff were proposed, Mr. Blake moved for letters, memorials, or representations asking for the proposed increases. The motion was voted down, after Sir M. Bowell, for the Government, had insisted that the communications were of a private character, and that it would destroy any chance of obtaining information from manufacturers if the letters that were received with respect to the changes proposed were made public. ${ }^{1}$.

A privately conducted investigation preceded the tariff revision of 1894 . It was undertaken by Sir John Thompson, who was then Prime Minister, and Mr. Foster, Minister of Finance. Sir R. Cartwright and Mr. Mills moved for copies of the shorthand notes of the evidence. Sir R. Cartwright asserted that the House had the right to see this evidence, because the manufacturers had gone to the ministers declaring that they could not make an honest living by their own exertions and industry, and had demanded that the rest of the people of Canada should be taxed for their benefit. The answer of the Government was that the shorthand writer who was with the ministers was private secretary to one of them; that there had been no tariff commission; that what notes had been taken for the information of the ministers had been stolen; and that they were not available even for the Government. ${ }^{2}$

1 Dominion Annual Register, 1883, p. 33.

2 House of Commons Debates, May 28, 1894. 
Objections such as these were always made by the Conservative governments to any investigation of their relations with the protected interests. It is most improbable that ministers ever delegated a man to act as recording secretary at the Red Parlour, or that a ledger account was kept with the manufacturers. It may be affirmed, however, that much of the political history of Canada will need rewriting should it ever be discovered that there was no ground for the persistent and specific allegations in and out of Parliament between 1879 and 1896 as to the place which the Red Parlour occupied in the politics of the protective tariff.

Canada had had ten years of the Conservative National Policy before protests in England against tariffs adverse to British trade came to an end. There was no remonstrance from the Colonial Office after those to which Galt's tariff of 1859 gave rise. But in 1862 Galt had to listen to much plain speaking about colonial responsibilities and colonial trade from two or three members of the Manchester Chamber of Commerce. ${ }^{1}$ In 1864, Cardwell, who was then Secretary of State for the Colonies, was urged in the House of Commons to appeal to the Canadian Government to remove the duties on British exports ; ${ }^{2}$ and in 1865 , in the debate on the Canadian Fortification Bill, Bright, in emphasising the fact that

1 At Town Hall, Manchester, September 25, 1862.

2 Hansard, series iii. vol. clxxiv. pp. 1770, 1771. 
Canada levied higher duties on British manufactures than the United States had done before the War of the Rebellion, and much higher duties than were levied by France, expressed his opinion that if by a friendly separation from England Canada became an independent nation, "its tariff would not be more adverse to our manufacturers than it is now." 1

The fiscal policy of Canada from 1865 to 187.9 attracted little or no public attention in England, chiefly because, except for the duty on coal in the tariff of 1870 , and the increase in duties in 1874 to seventeen-and-a-half per cent, due to the financial needs of the Dominion, there were few changes that adversely affected British trade. In 1879, however, there was much comment in the House of Commons on the new fiscal departure at Ottawa. It was stated by Sir Michael Hicks-Beach, the Colonial Secretary, that under the revised instructions given to the Marquis of Lorne when he became GovernorGeneral in 1878 , it was no longer the rule that measures enacted by the Dominion Parliament imposing differential duties should be reserved for sanction by the Government in London. The change, Sir M. HicksBeach assured the House, was made without any reference to a protectionist policy; while as regards the tariff of which complaints

${ }^{1}$ Bright's Speeches on Questions of Public Policy, edited by Thorold Rogers, i. p. 153. 
were made, the Colonial Secretary stated that there was nothing in it which had not been previously sanctioned, at least in principle, by the Canadian Legislature. Subject to treaty obligations, added Sir Michael, the British Government held that the fiscal policy of Canada rested with the Dominion Parliament. ${ }^{1}$

The last protests in Parliament were in 1887. The increased duties on iron were then discussed with considerable feeling both in the House of Commons and the House of Lords. But again the position of the Government was that assumed in 1879 ; and the debates in the two Houses are now of significance only for Granville's comment that it would be a sad bathos in the year of the Jubilee Colonial Conference, if the Government was not able by friendly and moderate counsels to modify the sudden blow which had been struck at the best interests of. Great Britain and Canada $;^{2}$ and for the suggestion made in the House of Commons, by Gourley of Sunderland, that the British Government before committing itself to a proposal which was then pending for a subsidy of $£ 45,000$ a year to a line of mail steamers from Vancouver to China and Japan, should stipulate with the Canadian Government for a modification of the new duties on iron and steel. ${ }^{3}$

Once, and only once after 1879, was there

1 Cf. Hansard, series iii. vol. ccxliv. pp. 1310-1313.

2 Ibid. series iii. vol. ccexviii.

3 Ibid. 
a direct appeal to the Canadian Government for easier treatment for British exports. Macdonald was in London in 1880, and while there a deputation from the Manchester Chamber of Commerce waited upon him. His answer was that the National Policy was intended to foster the infant industries of Canada, and that there was at Ottawa no intention to change it. Free trade, he added, might answer for a country like England with industries established. It would not answer for a young country like Canada. ${ }^{1}$ Bright's speech at Birmingham in 1885 was the last protest in the constituencies in England of which there is any record. The occasion of it was the activity of the now defunct Imperial Federation League. Macdonald had recently been prominent at a meeting of the League in Loudon. Bright recalled the fact that Macdonald was Premier because he was the most active protectionist politician in Canada. "Yet," he remarked, "he appears at the Imperial Federation League meeting, and gives his countenance to the proposition that Canada and the United Kingdom shall be made one. I could not conceive of any man having the face to appear at a meeting for that purpose holding such a position." ${ }^{2}$ But Bright did not know, or did not care to comment on the fact, that the Conservative politicians in Canada, who always lay most fulsome emphasis on Empire

${ }^{1}$ Dominion Annual Register, 1880-81, p. 251.

2 Times, Jannary 30, 1885. 
and its glories, and throw most energy into flag-waving when Reuter's correspondent is on hand, are the men who are most extreme in their advocacy of protection, and least disposed to tariff concessions to Great Britain. 


\section{CHAPTER XII}

\section{THE LIBERALS ADOPT AND EXTEND THE NATIONAL POLICY. 1896-1904.}

The system of protection which is maintained by the Government, that is to say of levying tribute upon the people, not for the legitimate expenses of the Goverument, but for a private and privileged class, should be condemned without qualification. Let it be well understood that from this moment we have a distinct issue with the party in power. Their ideal is protection, ours is free trade. Their immediate object is protection, ours is a tariff for revenue only. Upon this issue we engage the battle from this moment forward; and I ask you once more never to desist until we have achieved victory, until we have freed this country from the incubus which has been weighing it down for fifteen long years.-Sir WILFRID LAURIER.

Is point of fact our political freedom and our social welfare are to-day in infinitely greater peril from Penusylvania's iron masters and the owners of silver mines in Nevada than from all the ignorant foreigners that have flocked to us from Europe.-JoHx Fiske.

The policy of the Laurier Government with regard to protection has been characterised as a betrayal of Canadian Liberalism. Betrayal is a strong word. But an examination of the 
fiscal and bounty legislation at Ottawa since 1897 abundantly justifies its use, if all the vehement opposition of the Liberals to the National Policy had any sincerity. Sir Leonard Tilley, when he introduced the National Policy tariff of the Macdonald Government in 1879, asserted that the aim of the policy was to reduce imports. The aim of the legislation which since 1897 has been carried through the House of Commons by Mr. Fielding, the present Minister of Finance, has been exactly the same. The only departure from the main lines of the National Policy since 1896 is the preferential tariff for Great Britain of 1897. Great care was then taken to prevent the preferential tariff from making inroads on the protection which Conservative tariffs had afforded to Canadian manufacturers; and in 1904, and again in 1907, the preference was reduced on many lines of imports at the urging of manufacturers who feared British competition.

The Conservative Governments which were in power from 1879 to 1896 would make no preference in the tariff for imports from Great Britain. Their policy was uniform duties for all imports regardless of the country of origin. But had they had the foresight to make such a departure as that for which the Laurier Government has been so much commended in England, and had they at the same time taken the precautions which the Laurier Government took in 1897, 1904, and 1907, 
that not a solitary Canadian industry should be left exposed on the outside of the tariff breastworks, the Conservatives would have alienated none of their friends of the Red Parlour, nor endangered a single contribution to the party campaign funds.

It is not for me at this late date-ten years after the first enactment of the preference-to suggest to British manufacturers and exporters that they should look a gift horse in the mouth. In view, however, of the present agitation in England for a system of British and Colonial preferences, it should be on record (1) that the preferential tariff as it now stands, after the changes made in 1904 and 1907 , endangers no protected interest in Canada-that all existing industries are now amply protected against British competition ; (2) that under the existing fiscal system, with its constantly recurring surpluses due to the tariff, it has entailed no real or embarrassing loss of revenue; and (3) that the British preference affords no general or widespread relief to consumers against the exactions of the tariff-protected Canadian manufacturers.

Many industrial interests - notably the manufacturers of cotton goods, of shoes, and of plated tableware, and of the cheaper descriptions of cutlery, jewellery, and clockshave to-day from two-and-a-half to five per cent more protection against American competition than they had under the National Policy tariff which was on the statute book in 1896 
when the Liberals came into power. This increased protection is to safeguard them against the preference; but it should always be kept in mind that it is nowadays protection against American competition that Canadian manufacturers most desire. The largest volume of imports into Canada streams in from the United States. If the protected interests in Canada would graciously permit the Government to impose only revenue duties on imports from Great Britain the trend of trade could not be greatly changed.

Proximity, climate, industrial and social conditions, all tend to identify the needs of Canada with those of the United States. What British manufacturers have to offer has for half a century past increasingly failed to meet Canadian needs. Many of these needs are better met by Americans, because American manufacturers have long been meeting the same needs in their own country. Except as regards clothing fabrics and household furnishings of textiles, and also part of the output of British iron and steel plants, such as rails, steel plates, and cast-iron pipes, the needs of England and of the United States and Canada are not identical. The western world has its peculiar and well-defined needs due to climatic, economic, industrial and social differences between the New and the Old World.

It is largely because of this identity in the Canadian demand, as well as the proximity of 
Canada to the United States, that Canadian imports from the United States have increased at a much greater ratio than imports from Great Britain, in spite of ten years of the preferential tariff-in spite of the growth of manufacturing in Canada-and in spite of the fact that since 1880 a hundred and thirty American manufacturing concerns have been established in Canada. ${ }^{1}$ These American firms, mostly in the iron and steel and wood-working industries, have crossed the border on account of the high duties in the Dominion tariff, the "made in Canada" amendments to the Railway Subsidies Act of 1900 and to the Dominion patent law of 1903 , and the order in council of the Ontario Government of 1897 -in retaliation for the Dingley Act-which provides that all lumber cut on Crown lands in Ontario shall be manufactured in Canada.

Except to some degree as regards the British preference, the changes in the tariff schedules in 1897 and 1907 have brought no such relief from the burden of the protective system as was again and again promised by the Liberals during the years when they were in opposition. In many instances the burden of the tariff in 1907 is much heavier than it was in 1904. When I come to examine the bounty policy of the Laurier Government, the amendments to the Railway Subsidy Act and the patent laws, the legislation against dumping, the new regulations intended

1 Free Press, Winnipeg, July 1, 1907. 
to reduce the circulation of American trade advertising, the tariff war with Germany, and the readiness with which the tariff question was reopened at the bidding of the Canadian Manufacturers' Association, and the many new concessions that were made to the protected interests in the revision of 1906-7, it will become apparent, I am convinced, that the Liberal Government has not only adopted the National Policy of the Conservatives, but has greatly strengthened and extended it, and has fastened it more securely on the people of Canada.

It was the aim of the originators of the National Policy, as then openly proclaimed by Macdonald and Tilley, to reduce imports. Without any doubt this has been the aim of the Liberal governments since 1897. It is an aim that they have pushed with even more vigour; for, unlike the Conservative governments, the Liberal champions of the National Policy have had to meet no opposition in the House of Commons. The Conservatives have from time to time protested against the British preference. Occasionally they have complained that protective duties were not advanced to the Dingley level; but on the main policy of legislation for the exclusion of imports the Liberal Government has had nothing but aid and support from the Conservative Opposition.

The protected interests have always had the ready ear of the Liberal Government. It 
has been prompt to give legislative form to new devices for reducing imports, heedless of the uncompromising opposition of the Liberals to protection from 1879 to 1896 , and of their pledges, which were embodied in the Liberal programme of 1893 , of a return to a tariff for revenue, and an end to the system under which industry leans on the politician.

Before examining the first National Policy tariff of the Liberals it is expedient to take note of two speeches by Sir Richard Cartwright, made from the Opposition benches in 1890, and of the Ottawa Convention, at which the Liberal leaders and Liberals of the rank and file from every province except British Columbia proclaimed their policy as to tariffs and bounties.

Sir Richard was in a reminiscent mood when he made the first of these speeches of 1890 ; for he went back to the general election of 1878, at which the Mackenzie Government was defeated. He characterised the National Policy as a subservient imitation of the American fiscal policy-as in contradiction to the British policy for which he and his colleagues on the Liberal benches underwent defeat. "We fought and fell," he said, "for the policy of the British Empire, the policy of a revenue tariff, the policy of just taxation, which would take no more out of the poor than out of the rich." " Again, in the second speech he went back to the Liberal

${ }^{1}$ House of Commons Debates, April 11, 1890. 
defeat in 1878, and to the community of interests that was then established between Macdonald and the Conservatives and the protection-seeking manufacturers. "Finding we were not going to tax the people," he then said, "the leader of the present Government made an appeal to a set of gentlemen who put themselves up for sale, and who, the moment I refused to buy them, ${ }^{1}$ went and sold themselves to honourable gentlemen opposite. Yes, that is what they did. There never was an elector who sold himself for five dollars, who sold himself more completely than the protected manufacturers of Canada sold themselves to honourable gentlemen opposite. We did not buy them; and they sold themselves and their votes to gentlemen opposite." 2

There was no wavering on the part of the Liberals in the House of Commons so long as the Conservative Government was in power. Their opposition became more uncompromising as the community of interest between the manufacturers and the Government became closer and as the existence of the Red Parlour became more widely known. Liberals in the constituencies supported the Opposition in Parliament; so did such Liberal newspapers as the Globe of Toronto, the Witness of Montreal, and Chronicle of Halifax; and at the Ottawa Liberal Convention in June 1893-

1 In 1876, when the Mackenzie Government decided not to increase duties from serenteen-and-a-half per cent to twenty per cent.

${ }^{2}$ House of Commons 1)bates, April 16, 1890. 
the largest, most representative, and most enthusiastic political convention ever held in Canada-the Liberals reaffirmed their hostility to the National Policy, and proclaimed the attitude of the Liberal party towards protection and government largesse to industry.

Mr. Fielding was Chairman of the Committee on Resolutions; and from the Committee he reported the following resolutions condemning the National Policy and enunciating the fiscal policy of the Liberal party, which were enthusiastically adopted by the Convention :-

The tariff - We, the Liberal party of Canada in Convention assembled, declare-

That the customs tariff of the Dominion should be based not as it is now, upon the protective principle, but on the requirements of the public service;

That the existing tariff, founded upon an unsound principle, and used, as it has been by the Government, as a corrupting agency wherewith to keep themselves in office, has developed monopolies, trusts, and combinations ;

It has decreased the value of farm and other landed property ;

It has oppressed the masses to the enrichment of the few ;

It has checked immigration ;

It has caused great loss of population;

It has impeded commerce ;

It has discriminated against Great Britain.

In these and many other ways it has occasioned great public and private injury, all of which evils must continue to grow in intensity as long as the present tariff system remains in force.

That the highest interests of Canada demand a 
removal of this obstacle to our country's progress, by the adoption of a sound fiscal policy, which, while not doing injustice to any class, will promote domestic and foreign trade, and hasten the return of prosperity to our people.

That to that end the tariff should be reduced to the needs of honest, economical, and efficient government.

That it should be so adjusted as to make free, or to bear as lightly as possible upon, the necessaries of life, and should be so arranged as to promote freer trade with the whole world, more particularly with Great Britain and the United States.

We believe that the results of the protective system have grievously disappointed thousands of persons who honestly supported it, and that the country in the light of experience is now prepared to declare for a sound fiscal policy.

The issue between the two political parties on this question is now clearly defined.

The Government themselves admit the failure of their fiscal policy, and now profess their willingness to make some changes; but they say that such changes must be based only on the principle of protection. We denounce the principle of protection as radically unsound and unjust to the masses of the people, and we declare our conviction that any tariff changes based on that principle must fail to afford any substantial relief from the burdens under which the country labours. This issue we unhesitatingly accept, and upon it we await with the fullest confidence the verdict of the electors of Canada. ${ }^{1}$

The official verbatim report of the Convention extends to a hundred and fifty pages. At least half of these are occupied by discussions of the fiscal policy-all in the spirit of the foregoing resolutions, and similar in tone to

1 Official Report of Liberal Convention, 1893, pp. 71, 72. 
CII.

the onslaughts on the National Policy which had been made by Sir Wilfrid Laurier, Sir Richard Cartwright, and other leaders of the Liberals in the House of Commons between 1879 and 1893. The speeches of Sir Wilfrid Laurier, Sir Richard Cartwright, and Mr. Paterson are now of most significance in the history of protection in Canada; because in association with Mr. Fielding, who was charged with the drafting of the resolutions, these leaders are responsible for the fiscal policy which has been in operation at Ottawa between 1896 and 1907.

\section{Said Sir Wilfrid Laurier-}

Our first duty is to arouse the people to a sense of their immediate danger, and the immediate danger is the tariff which now oppresses Canada. There is, as you well know, a universal consensus of opinion among all classes, nay, among all parties in this country, that the tariff which now prevails in Canada is a burdensome tariff; that it is an oppressive tariff; and that what was known at one time as the National Policy has been found to be a fraud and a failure. I say there is this universal opinion amongst us that the tariff has to be reformed. You remember what took place previous to the defeat of Mr. Mackenzie. At that time we had for Premier, as you well know, a man of unbending rectitude. There never was a purer or a greater man in my estimation in Canada than Alexander Mackenzie. He would not stoop to pander to what he supposed to be popular prejudice. He thought that this country could not be made prosperous by high taxation. The people believed otherwise. I have no fault to find with anybody, and no criticism to offer. The time for recrimination is gone. But I appeal to 
your judgment in the face of the experiment of the last fifteen years under the system which was introduced by the Conservative party, which was dubbed the National Policy, to say if that system was not vicious in principle, iniquitous in its terms, and dangerous in its consequences. I say that it is vicious in principle. I want to know-and I put the question so as to be heard through the length and breadth of this country-by virtue of what principle will you tax a man to enrich his neighbour? By virtue of what principle will you tax the farmer in order to give work to the working man? On what principle will you tax the working man in order to give better prices to the farmer? ...

It is true that the National Policy is nothing but a servile copy of the American system of protection. The Conservative party - the loyal party - left the example of the Mother-country and went over to the other side for a policy, and they brought it back singing "God Save the Queen." They advocated that policy in 1878. In 1879, after they were returned to power, they introduced an American nostrum, and gave it to the loyal people of Canada. When they were told by people like myself, who claim to be as loyal as they are, but whose loyalty is in the heart, not on the lips, "You are endangering British connection," they said, "So much the worse for British connection." . . .

I submit to your judgment that the servile copy of the American system which has been brought amongst us by the leaders of the Conservatives is, like its prototype, a fraud and a robbery; and I call upon you, one and all, to pronounce at once and give your emphatic support to the proposition that we shall never rest until we have wiped away from our system that fraud and robbery under which Canadians suffer. But there is something more. We pronounce to-day in favour of tariff reform. ... I submit to you that the ideal fiscal system is the British system of free trade. Sir, my 


\section{PROTECTION IN CANADA сн.}

loyalty, as I stated, does not ooze from the pores of my body; but I do want to go for an example to the Mother-country and not to the United States, much as I respect and love the people on the other side of the line. I say the policy should be a policy of free trade, such as they have in England; but I am sorry to say that the circumstances of the country cannot admit at present of that policy in its entirety. But I propose to you that from this day henceforward, it should be the goal to which we aspire. I propose to you from this day, although we cannot adopt the policy itself, to adopt the principle which regulates it; that is to say, that though it should be your misfortune for many years to come to have to raise a revenue by customs duties, these duties should be levied only so far as is necessary to carry on the business of the Government. I submit to you that not a cent should be extracted from the pockets of the people except every cent goes into the treasury of the people, and not into the pockets of anybody else. I submit to you that no duty should be levied for protection's sake, but levied altogether and only for the purpose of filling the treasury to the limits required. I submit to you that every cerit that is levied should be levied first and foremost on the luxuries of the people. I submit to you, therefore, that the system of protection which is maintained by the Government, that is to say, of levying tribute upon the people not for the legitimate expenses of the Government, but for a private and privileged class, should be condemned without qualification. Let it be well understood that from this moment we have a distinct issue with the party in power. Their ideal is protection; our ideal is free trade. Their immediate object is protection; ours a tariff for revenue only. Upon this issue we engage battle from this moment forward; and I ask you once more never to desist until we have freed this country from the incubus which has been weighing it down for fifteen 
long years. Nothing is more difficult-that is one of the evils of protection-than to wipe away protection, because under it interests have been established which every man who has at heart the interest of all classes must take into consideration. It is always easy to increase the tariff, because by doing so you increase the private fortunes of certain individuals; but whenever you decrease the tariff it has to be done with careful consideration, and I am sure that when the Liberals are in power they will not be indifferent to this primary truth.

One of the evils of the National Policy and the system of protection has been here, as everywhere else, to lower the moral level of public life. It is a subject, however, into which I do not desire to enter at length. I speak of it more in sorrow than in anger; but I tell you this, if you want to purify the political atmosphere, not a cent is to be levied except what is necessary to carry on the legitimate expenses of the Government economically administered.

Sir Richard Cartwright, like Sir Wilfrid Laurier, spoke at the opening meeting of the two-days' Convention before the Convention was permanently organised, and the resolutions from Mr. Fielding's committee had been submitted to it. Said the present Minister of Trade and Commerce :-

It is not a mere figure of speech to say that the people of Canada at present are standing at the parting of two ways. For a period of fourteen years or more, as our public records only too clearly testify, a large portion of the people of Canada have been consenting parties, if not willing instruments, to what has proved to be nothing less than a carnival of corruption. For fourteen years a very large portion of the people of Canada have been chasing a will-o'-the-wisp, which, as 
is the custom of that wandering spirit, has ended by leading them into a very foul quagmire. I do not know when it will be the fortune of Canada to have a historian who will truthfully depict the events of the last fourteen or fifteen years; but I am afraid that in stating the facts he will be obliged to state that the people of Canada during that period have been duped and plundered as few other peoples ever have been. $\mathrm{He}$ will be obliged to state that so far as a great part of the people is concerned, they desired to be duped and plundered.

It has been my painful duty for a good many years to face the facts, and very unpleasant facts I have found them to be very often. I have always desired, as far as I could, to respect all my opponents whom I have found any reason to believe to be actuated by honourable purposes. And I do not mean to say that in the ranks of our opponents there are not a very considerable number of worthy, but utterly mistaken men. But, on the other hand, I have to say to you, in order that there may be no illusions on our part as to the character of the foe with whom we have to deal, we are practically face to face with a vast and wellorganised conspiracy-with a conspiracy which controls a very large portion of the press of this country-which controls a very large part of the active wealth of this country - which has the entire resources of the Government of Canada at its disposal-a conspiracy whose motto is robbery, and whose arms are fraud and bribery. ... .

Turning to the other side, the material injury of which we have to complain is hardly less in magnitude than the moral degradation to which I have alluded. If you add together the sum which has been put into the Treasury, and the larger sum which has been extracted from the pockets of the people for the benefit of a few privileged and favoured individuals, you will find that the total for the last fourteen years is 
hardly less than a thousand millions of dollars. When Germany levied her enormous war indemnity upon France twenty years ago, the total sum which the victors dared to exact from the vanquished country hardly amounted to the sum which has been levied from you, and taken out of your pockets, for the purpose of entrenching your oppressors in power and enabling them to defeat the wishes of the people. Looking at the relative population and the relative resources of the two countries, it is safe to say that the sum exacted from us in that time is equal to eight times the enormous war indemnity exacted from France. ...

It is perhaps a matter of regret that in the discussions which from time to time have taken place on this subject, we rather ignore the political working of the protective system, and perhaps dwell a little too much on the material injury it has done to our country. I think it must be obvious to every one who will give the slightest attentive consideration to the working of the protective system in this country or elsewhere, that the moment you introduce that system you create a class whose interests are essentially different from those of the people at large, and who become the ready contributors to corruption funds, sharing with their masters the plunder which they have been enabled to take from the people. More than that, I have always held that in Canada protection was not only a crime, but a blunder. I have always felt that there was absolutely no excuse for introducing such a system in a country like this. There is no factor in the condition of Canada that would ever justify us in expecting that we could thrive by taxing our people, or that by isolating them from the rest of the world we would be able to increase their prosperity, improve their resources, or increase their numbers.

It is our duty now to face the situation as best we may; and I believe with Mr. Laurier, that the first 
duty of the reform party, the duty that lies next to hand, the duty which is most clearly within their power to perform, is at once and completely to reform the tariff of this country, to reduce it to a revenue basis, to see that no money from this time forth shall, so far as we can prevent it, be taken out of the pockets of the people for any other purpose than for the legitimate needs of the whole community. As regards protection, I may say at once that I think no man who has taken the trouble to examine the working of the protective system will fail to endorse the statement I make that liberty and protection are a contradiction in terms. You can have no true liberty under a protective system; you can have no true liberty under a system the function of which is to create a privileged class, and to concentrate an undue proportion of the wealth of the community in the hands of a few individuals. I contend that protection, besides being the cause of the worst political corruption, is the deadly foe of all true freedom; and therefore the deadly foe of every Liberal who desires to see his country a free country. ... .

I believe that you will all agree with my esteemed friend Mr. Laurier in declaring that an overwhelming case has been made out for a general and decisive reform strictly on the lines of a revenue tariff; a reform which will provide that for the future not one cent shall be exacted from the people of Canada except for the needs and uses of the people who contribute to these taxes. ...

The resolution on the tariff and the fiscal policy of the Liberals was submitted at the second day's sitting of the Convention. It was proposed by Sir Wilfrid Laurier, and seconded by Mr. William Paterson, who since 1896 has been Minister of Customs.

"It is," said Sir Wilfrid, "a thorough arraignment 
of the policy the Government has followed. It sets forth all the evils that have flowed from the system of protection, and it draws the line clear and distinct between truth on the one side and error on the other; between the policy of liberty and freedom and the policy of slavery, because I leave it to the judgment of every free man, to the farmers, and, above all, I leave it to the working men in the cities, if protection is anything else than slavery. The Government has no right to take from the earnings of any one anything except what is due to carry on the business of Government. The moment the Government takes one cent from your pocket, and that cent does not go into the treasury of the country, that is robbery to your prejudice. Therefore, I think that the resolution should meet with your approval; and I am glad to say that from this day we have a clear arraignment of the Government, which we shall not cease to urge until the great battle is fought, and we have achieved victory."

"To-day," said Mr. Paterson, "you have laid down in clear and emphatic language, what? Not a new principle. You have laid down and emphasised again the principle held by the Liberal party in this matter of trade and commerce, that in the levying of the taxes of the country regard should only be had to the necessities of the revenue, and that the Government should not seek by tariff legislation to favour any particular class in the community. I say this is no new principle. A revenue tariff was in force when our late leader, Alexander Mackenzie, who has gone to his long rest, held the reins of power; and he and his Govermment fell because he would not yield to the cry for a protective tariff. From that day to this the Liberal party have not ceased to proclaim that they believed that it was not right or just that protection, as a principle, should be recognised by the Government of the country; and that they believed that the duty of the Government was to raise the necessary revenue 
to discharge the duties devolving upon the Government, and to leave the people free to work out their own destiny, giving no undue advantage to any one portion of the community over another."

The last of these condemnations of the National Policy that need be quoted is that by Sir Wilfrid Laurier, at Winnipeg, in September 1894. It is a reiteration of the convictions he had expressed at Ottawa in proposing the resolution which had come from Mr. Fielding's committee. Recalling the attitude of the Liberal party towards protection, Sir Wilfrid said :-

We stand for freedom. I denounce the policy of protection as bondage-yea, bondage; and I refer to bondage in the same manner in which American slavery was bondage. Not in the same degree, perhaps, but in the same manner. In the same manner the people of Canada, the inhabitants of the city of Winnipeg especially, are toiling for a master who takes away not every cent of profit, but a very large percentage, a very large portion of your earnings for which you sweat and toil. ${ }^{1}$

It is the practice with political parties in Canada, as with the Republican and Democratic parties in the United States, to issue campaign books on the eve of the general election. The Liberal Campaign Book for the general election of 1896 was sent broadcast over the Dominion in $1895 .^{2}$ It was a book of a hundred and twenty-five pages.

1 Free Press, Winnipeg, September 3, 1894.

2 Federal Elections, 1895 ; The Issues of the Campaign, Marwick Bros. and Rutter, Toronto, 1895. 
In it were embodied the resolutions adopted at the Ottawa Convention, some of the speeches, and scores of pages of argument and statistical demonstration against the National Policy. By this time the Dominion was weary of the Conservative Government. Ministers, in 1896, were quarrelling among themselves. For a year before the election the Liberals had conducted an active propaganda; and the result was that in July 1896 , Sir Wilfrid Laurier formed his first administration. Of it were Liberal leaders from all the then existing provinces, nearly every one of whom had spoken at the Ottawa Convention.

The tariff was revised in April 1897. Before the revision Mr. Fielding, Minister of Finance; Sir Richard Cartwright, Minister of Trade and Commerce; and Mr. Paterson, Minister of Customs, as a commission, visited Toronto and Montreal and a few other large centres of trade and industry to give manufacturers and importers opportunities of expressing their view on tariff economy. The sittings of the commission were open to the press; and this throwing open of the inquiry to the public constituted an innovation in tariff procedure. Hitherto ministers and manufacturers had been in conference in the Red Parlour and at Ottawa. In the later years of the Conscrvative régime ministers had gone as far afield as the Maritime Pro-

${ }^{1}$ It went into operation on April 23, 1897.-60-61 Vict. c. 16. 
vinces to learn how the tariff was building up industries, and what changes were deemed advisable by manufacturers. But the interviews were in private; and ministers had always refused to lay before the House of Commons the memorials or representations that had been submitted to them by the manufacturers.

At the tariff inquiry of 1896 shorthand writers were in attendance, and the transcript of their verbatim notes of the public proceedings was treated from the first as a Government document. Unlike the tariff inquiry of 1905-6, the inquiry of 1896 was altogether neglected by farmers and general consumers. It was a new departure, and not popularly understood; and the petitioners or witnesses were either manufacturers or importers. They were mostly manufacturers ; and they succeeded in convincing the newlyelected Liberal Government that any disturbing changes in the schedules, and any abandonment of the bounties which the Conservatives had established in 1883-any such changes as had been so uncompromisingly threatened at the Liberal Convention of 1893 -were inexpedient, unwise, and impolitic, and would dislocate Canadian industries, and be hazardous to the eapital embarked in them.

It is now well known that at this juncture the coal and iron interests of Nova Scotia obtained the sympathetic ear of the Government; that the cotton combines which have 
their headquarters in Montreal did likewise; also that the bankers, financiers, and company promoters of Montreal, Toronto, and Halifax supported the plea of the protected manufacturers and the beneficiaries of the bounty system that it was inexpedient that there should be any fiscal legislation on the lines of the Ottawa resolutions. All these influences were brought to bear on the Government in the winter of 1896-97; and the result was that the Government recognised and conceded that there were vested interests in the protective tariff and in the bounty enactments which National Policy governments had put on the statute book.

As soon as the Liberals came into power a situation presented itself of exactly the kind anticipated by Sir Richard Cartwright in 1879 . It will be recalled that the present Minister of Trade and Commerce then announced that should the Liberals come into power, the new Government would not recognise any claim to vested interests that the manufacturers might seek to establish. But in 1897 the claim of the manufacturers was fully recognised by an administration of which Sir Richard Cartwright, next to the Premier, was the most prominent and most popularly trusted member. The fact is that between 1879 and 1897 a new privileged order had been established by Dominion statutes. Canada had had her privileged orders before 1879. Two of them had been imposed 
on it by the Old World; the third had been evolved out of the peculiar social conditions of the pioneer days of the English-speaking colonies. France, as far back as $1623,{ }^{1}$ had set up the seigniorial system in Quebec. The Family Compact had developed out of United Empire Loyalist migration, and had asserted itself in Ontario, Nova Scotia, and New Brunswick from the early days of organised British settlement in these colonies. Special privileges for the episcopal clergy in Ontario dated from 1791. But all these privileged orders were swept away by the democratic reforms which preceded Confederation.

It would seem, howerer, from the experience of Canada and the United States, that the New World, like the Old, is fated to have its privileged orders. In the United States manufacturers became firmly established as a privileged order during the political turmoil that attended the end of the old slave-owning aristocracy south of Mason and Dixon's line; and in Canada the echoes of the agitations that had resulted in the breaking up of the Family Compact and the abolition of the archaic seigniorial system in Quebec, and the clergy reserves in Ontario, had not died away before a new privileged order-the Order of Protected Manufacturers - was set up in Canada, and had delegated to it by Parliament the power of taxation to be used for private and individual gain. Aristocracies of this new

1 Cf Munro, The Seigniorial System in Canada, p. 21. 
type have none of the graces of the old feudal aristocracies of Europe. They have all, and more than all, the social and economic disadvantages and evils. Noblesse oblige has never been recognised as the rule of conduct by this new aristocracy in Canada, buttressed as it is by tariff and bounty enactments in place of feudalism and the power that comes from territorial possessions; and delegated powers based on statutory enactments in the hands of this new aristocracy are used to the full for individual and unsocial ends.

It is one of the ironies of Canadian history that responsibility for the full recognition of this new privileged order and for nearly a score of enactments continuing, extending, and guaranteeing its existence, should lie with the Liberal party - with the party which came into existence in the early decades of the nineteenth century to sweep away the privileged orders which Old World conditions and politics had imposed on Canada. But the result of all the forces and influences at work on the Laurier Government in the winter of 1896-97 was, as Mr. Paterson explained to the disaffected and outspoken Liberal farmers at Chatham, in November 1905, that it came to the comfortable conclusion that no administration was justified in taking the risk of sweeping changes in the tariff--of facing the danger of dislocating trade and industry, and perhaps of throwing thousands of men and women out of employment. 
The Government accordingly turned its back on the resolution of the Ottawa Convention that the "National Policy tariff was founded upon an unsound principle, and had developed monopolies, trusts, and combinations," and "that it should be reduced to the needs of honest, economical, and efficient government." Sir Wilfrid Laurier ignored his declaration that if the people of Canada desired to purify the political atmosphere " not a cent must be levied except what is necessary to carry on the legitimate expenses of the Government." Sir Richard Cartwright ignored his reiterated statements in the House of Commons that protection was legalised robbery; and also his emphatic declaration at the Liberal Convention that "there could be no true liberty under a system the function of which is to create a privileged class and to concentrate an undue proportion of the wealth of the community in the hands of a few individuals."

The few individuals whose position and extraordinary privileges were thus described by Sir Richard Cartwright in 1893, succeeded between July 1896 and April 1897 in persuading the Laurier Government that their interests were paramount to those of the whole people of the Dominion. 'The Government abandoned the principle of a tariff for revenue only; and on April 23, 1897-the day after Mr. Fielding submitted the new tariff to the House of Commons-when the 
members of Canada's privileged order examined the tariff schedules, except for those who were engaged in the woollen industry and the refining of illuminating oils, there was not a corporal's guard of them who could make affidavits that they had lost anything material of their tariff protection by the change of government.

The preference for Great Britain was the only departure of any significance from the National Policy. Some of the schedules were simplified in the new tariff. Mixed dutiesthat is, ad valorem and specific duties combined-were in most cases replaced by ad valorem duties. Here and there, with the low prices of ten years ago, these changes may have brought some relief to consumers, particularly in the woollen schedules; for the duties of twenty-five per cent ad valorem and five cents a pound on woollen fabrics, and of thirty per cent and five cents a pound on ready-made clothing, were replaced by an ad valorem duty of thirty-five per cent. Some of the duties on iron were decreased; but the loss to the manufacturers was compensated for by the increase in the bounties. The duty on stoves was reduced from twenty-seven and a half to twenty-five per cent; on carpets, mats, and rugs, from thirty to twenty-five per cent; on builders' hardware, from thirty-two and a half to thirty per cent; on pianos, from thirty-five to thirty per cent; and on illuminating oils, largely used all over rural Canada, 
the duty was reduced from six to five cents a gallon.

These decreases, however, were offset by increases in the cotton-schedules to safeguard the Canadian factories from the preference, and to afford them even higher protection against New England competition than they had had under Conservative tariffs. ${ }^{1}$ The general range of duties in the Liberal National Policy tariff of 1897, and their avowedly protectionist character, may be judged from the fact that embodied in it were eighty - three duties of twenty-five per cent, and seventy of thirty per cent; while fifty were of thirty-five per cent, which, except for two or three items, was the highest range of duties in the tariff of 1894 . Besides the reductions in the iron-schedules, which were of advantage to many manufacturers, there were also reductions on other raw materials, and the upward movement in prices that began in 1898 has since then more than compensated for the small reductions in many of the ad valorem duties.

To-day, ten years after the enactment of the first Liberal tariff, it is doubtful if there is a single manufacturer in Canada whose profit and loss accounts for the period from the revision of 1897 to the second revision in 1906 would show that he had lost a cent in consequence of the general tariff enacted in

1 The duty on grey unbleached cotton fabrics was $22 \frac{1}{2}$ per cent in the tariff of 1894 ; on cotton fabrics printed, dyed, or coloured, 30 per cent. These duties were increased by the tariff of 1897 to 25 and 35 per cent. 
1897. What loss of protection there was to Canadian manufacturing interests was due to the preferential tariff for Great Britain. The inroad this made was small until the full preference came into force in 1900 ; and the preference was so adequately hedged by increases in the general tariff from which the deductions in favour of British imports were made-one-eighth in 1897-98, ${ }^{1}$ one-quarter in 1898-1900, and one-third in July $1900^{2}$ and afterwards-that only the woollen manufacturers and the manufacturers of twine and cordage ever complained between 1897 and 1905 that their protection had been decreased by the preference for Great Britain.

It is true that when the Tariff Commission was on its tour in 1905-6 many manufacturers appealed for more protection against British imports than was afforded by the tariffs in force since 1897. Some of these complaints were due to the fear that the preference was to be increased. Others, as was elicited by the Commissioners themselves, when they were at Toronto, in the case of a plea for more protection against Great Britain on the less expensive kinds of jewelry, were based, not on any past experience of the preference, but on the apprehension that British manufacturers were about to take more advantage of it than they had hitherto done.

Tariff preferences for Great Britain had been discussed in and out of Parliament long

1 60-61 Vict. c 16.

263.64 Vict. c. 15. 
$\mathrm{CH}$.

before 1897. In a preceding chapter has been told the fate of suggestions of British preferences made in the discussions of the National Policy in the House of Commons between 1876 and the defeat of Mackenzie in 1878. In $1888 \mathrm{Mr}$. Marshall, a supporter of the Macdonald Government, moved a resolution affirming that it would be to the advantage of Canada to have closer commercial relations with the Mother-country. Mr. Marshall's motion was regarded as too indefinite; and Mr. D'Alton M'Carthy, another Conservative, gave notice of, but eventually did not move, a resolution going much beyond that of $\mathrm{Mr}$. Marshall. Mr. M'Carthy's resolution, had it been proposed, would have asked the House of Commons to affirm "That it would be in the local interests of the country that such changes should be sought for in the trade relations between the United Kingdom and Canada as would give Canada advantages in the markets of the Mother-country not allowed to foreign states, Canada being willing for such privilege to discriminate in her markets in favour of Great Britain and Ireland, due regard being had to the policy adopted in 1879 for the purpose of fostering the various interests and industries of the Dominion and to the financial necessities of the Dominion." 1

Sir Wilfrid Laurier (then Mr. Laurier, and not yet leader of the Liberal Opposition)

1 Globe, October 1, 1889. 
adverted to this movement in the House of Commons in an address to the Young Men's Liberal Club of Toronto in September 1889. "I may say at once," he said, after having recalled the terms of both the Marshall and the M'Carthy resolutions, "that I would be in favour of a more close commercial alliance of Canada with Great Britain. I would favour it with all my soul. But if there is any man who believes that such an alliance between Canada and Great Britain can be formed upon any other basis than that of free trade, which prevails in England, that man is a Rip van Winkle, who has been sleeping not only for the last seven years, but for the last forty-four years. The British people will not to-day go back on the policy of free trade which they have adopted; and Canada is not in a position at this moment, with the large revenue she has to collect, to adopt any other than a revenue tariff at best." "Mr. Marshall's resolution," added Sir Wilfrid Laurier, in commenting on its adoption in 1888 by the House of Commons, "indicated that the policy adopted should be that England should receive our cereals free of duty, but tax the cereals of every other country; and if they would do that we would be so magnanimous as to lower by a few inches the tariff which we have put in the face of British industries." 1 The McKinley tariff was enacted in 1890 . It was the most extreme protectionist tariff 
ever on the statute book at Washington until the Dingley Act took the place of the Wilson tariff in 1897. It was nearly as detrimental and as dislocating to several lines of Canadian industry-especially to farming and lumbering - as the Dingley tariff ; and it certainly inflicted the worst blow that Canada had suffered since the abrogation of the reciprocity treaty in 1866 . It was not then possible or expedient for Canada to retaliate; but as a measure of indirect retaliation it was proposed in the House of Commons, in April 1892, by a supporter of the Conservative Government, "that if, and when, the Parliament of Great Britain and Ireland admits Canadian products to the markets of the United Kingdom upon more favourable terms than it accords to the products of foreign countries, the Parliament of Canada will be prepared to accord corresponding advantages by a substantial reduction in the duties it imposes on British manufactured goods." As an amendment, Mr. Davies of Prince Edward Island (now Sir Louis Davies), who was Minister of Marine and Fisheries in the first Laurier administration, moved that inasmuch as Great Britain admitted the products of Canada into her ports free of duty, the House of Commons was of opinion that the then existing scale of duties "exacted on goods mainly imported from Great Britain should be reduced." 1

Mr. Fielding, in explaining to the House 1 House of Commons Debates, April 25, 1892. 
of Commons the preference to be established for Great Britain by the tariff legislation of 1897, recalled these earlier discussions. "Leading public men," he said, "have advocated preferential trade, but always annexing to their suggestions a demand with which it was well known England could not comply. All the advocates of preferential trade have assumed that, as a first step, England must put a duty on corn. We know that England does not view that project with favour. It may be that at a very early day they may see it in their interest to offer some preferential rate to the grain of Canada. If they can be induced to do that by fair argument, I have no doubt it will be a good thing for Canada. But why should we wait for England to take action. England has dealt generously with us in the past. She has given us liberty to tax her wares, even when she admits our goods free; and we have taxed them to an enormous degree." 1

Mr. Foster, who was the Minister of Finance responsible for the tariff of 1894 , and Sir Charles Tupper, who in 1897 was leader of the Conservative Opposition, both attacked the new departure. Mr. Foster laid most stress on the complicatious which would arise under favoured-nation treaties made by Great Britain. "It may be," he said, "that the Dominion of Canada, if it could make preferential terms with Great Britain and with

1 House of Commons Debates, April 22, 1897. 


\section{PROTECTION IN CANADA cн.}

Great Britain alone, would be willing to do it to an extent which might press hard upon the industries of Canada itself. But whilst, from the warm blood of loyalty that courses in her veins, she would make that sacrifice for Britain, it is another thing when we are asked to place our industries at the competition and mercy of a number of nations."

Mr. Chamberlain's suggestion of 1896 for a British Zollverein, made at the third Congress of the Chambers of Commerce of the Empire, ${ }^{2}$ was recalled by Sir Charles Tupper, who urged that it offered an opening for obtaining preferential trade with England. He bitterly complained that by the preference set up by Mr. Fielding's tariff this opportunity had been thrown away. "We find," he said, " that question of preferential treatment, with all its glowing prospects and opportunities for drawing Canada and the Mother-country more closely together, and at the same time greatly increasing the expansion and development of our country, thrust away, and this miserable system of differential treatment undertaken in the teeth of treaties and obligations by which the Mother-country is bound." 8

1 House of Commons Debates, April 23, 1897.

$2 \mathrm{Mr}$. Chamberlain suggested free trade within the Empire, leaving the contracting parties free to make their own arrangements with foreign nations, with the proviso that Great Britain should consent to put moderate duties on certain articles-corn, meat, wool, and sugar-which might be wholly produced in the colonies, the colonies to agree to a free interchange of commodities with the rest of the Empire, and to cease to place protective duties on any product of British labour.

${ }^{3}$ H̆ouse of Commons Debates, April 22, 1897. 
On the eve of the new tariff there was more nervousness among Canadian woollen manufacturers than among men interested in any other large industry. The woollen men were apprehensive that either by the readjustment of the schedules, or by a preference for Great Britain, there would be an inroad on the protection of the National Policy tariffs. While members were assembling and the galleries of the Chamber were filling in anticipation of Mr. Fielding's speech, I was permitted to read a telegram from. a woollen manufacturer sent to the Press Gallery, in which he announced for publication that if there were changes in the tariff adverse to the industry he would promptly close his mills. Had there been no preference for Great Britain Canadian woollen manufacturers would have lost practically nothing by the abandonment of the system of mixed duties and the substitution of ad valorem duties at the rate of thirty-five per cent. But the competition comes from Yorkshire, Wiltshire, and Scotland. The woollen industry, unlike the cotton industry, has never had to meet American competition; and undoubtedly the British preference, as long as it was fully in force, did make an inroad on the protection of the Canadian woollen mills.

The full preference, which reduced the duty by one-third was, however, in force on British woollens only from July $1900^{1}$ to June 8, $1904 .^{2}$

$163 \& 64$ Vict. c. 15.

24 Ed. VII. c. 2. 
The Canadian Manufacturers' Association came to the support of this threatened industry almost as soon as the reduced rate of 1900 on British woollens came into effect. The Association complained that British imports had increased from $\$ 6,295,000$ in 1897 to $\$ 8,960,000$ in 1901 ; that the aggregate value of the production of Canadian woollen mills had fallen from $\$ 9,750,000$ in 1896 to $\$ 7,000,000$ in 1900 - "which meant," it was insisted by the Association, " that nearly onethird of our manufactures in this line have been replaced by imported articles." ${ }^{1}$ At the annual convention of the Association in Montreal in October 1901, much attention was given to the preference on woollens; and from the woollen manufacturers' committee of the Association there was a resolution in which it was urged that the Canadian industry should, after allowance has been made for the British preference, have a tariff protection of not less than thirty per cent upon all classes of finished woollen, worsted, and knitted goods and carpets; and of not less than twenty per cent on all classes of yarns. ${ }^{2}$

There had been only one session of the Parliament of 1900-1904 when this demand was made by the Manufacturers' Association; and the demand was not acceded to by the Government until the eve of the general election of 1904. By this time the agitation 
of the Manufacturers' Association, begun in 1900 , for the revision of the tariff, was causing the Government some uneasiness; and by amendments to the Tariff Act which went into operation on June 8, 1904, the demand of the woollen manufacturers was granted by the Government. ${ }^{1}$ The bill by which this first curtailment of the British preference was made was before the House of Commons in April; and at committee stage there was a significant speech from a Liberal member - Mr. Hance Logan, a woollen manufacturer of Amherst, Nova Scotia. The significance of this speech touches the movement in England for preferences for colonial products.

"What we want in this country," said Mr. Logan, "is to impress upon the people that our true policy is Canada for Canadians, and to carry out that policy we must endeavour to use goods made in Canada. I have not the slightest doubt that nine-tenths of the members who have spoken here to-day are wearing English or Scotch tweeds on their backs, while crying out 'Canada for Canadians.' 'Made

1 Notwithstanding anything contained in Schedule D to said Act, 60 \& 61 Vict. c. 16 , the minimum duty on the following articles, when imported under the British preferential tariff, shall be as follows: fabrics, manufactures (not including blankets, bed comforters, counterpanes, or flannels), wearing apparel, and ready-made clothing, composed wholly or in part of wool, worsted, the hair of the alpaca, goat, or other like animal, n.e.s., cloths, doeskins, cassimeres, tweeds, coatings, over-coatings, and felt cloths, n.e.s., thirty per cent ad valorem. -4 Ed. VII. c. 11 . The blanket manufacturers were nct prominent in the movement in 1901 for the restoration of the piotection against British imports ; and the preference on the manufactures excepted in the foregoing clause was left as enacted in 1900 until the revision of 1906-7. 
in Canada' should be the watchword of the people of Canada. If the competition from Great Britain at present is too keen-and I fear it is-I am willing to leave the woollen industry of Canada and its future welfare in the hands of the present Government. But I desire to call your attention to one fact that seems to me very strange. Honourable gentlemen on the other side of the House are great Chamberlainites. They are always shouting in favour of Mr. Chamberlain. Yet the very first principle enunciated by Mr. Chamberlain is that this country should lower its tariff on goods which are peculiarly British. They know that if to-morrow Mr. Chamberlain were returned to power and he should ask the people of Canada to lower the duty on woollens which are manufactured in England, they would cry their hearts out before they would allow such a lowering to take place. If Mr. Chamberlain's policy means the destruction of Canadian industries for the benefit of British industries, I am opposed to that policy." 1

Between 1897 and the second revision of the tariff in 1906-7 there was quite a number of changes in the tariff, the more important of them being all in the direction of increased protection. There was also legislation on National Policy lines concerning the equipment of subsidised railways and the conditions under which patents for inventions are granted. The amendment to the railway code in 1900

1 House of Commons Debates, April 19, 1904. 
was the first concession to the "made in Canada" movement by the Laurier Government after it had revised the tariff in 1897 , and in the same year, and again in 1899, had continued and greatly extended the bounty system for the iron and steel industry.

Under the bounty legislation of 1897 and 1899 plants for the manufacture of steel rails were installed at Sydney, Cape Breton, and at Sault Ste Marie, Ontario. It was 1904 before these two mills were at work. Both companies were American promotions ; and early in $1900 \mathrm{Mr}$. Francis Clergue, the promoter of what is now the Algoma Steel Company at Sault Ste Marie, urged on the Government an amendment of the railway code that would call for the use of equipment made in Canada on railways to which Dominion subsidies were paid. ${ }^{1}$ The Government adopted Mr. Clergue's suggestion; and on July 12, 1900, the late Mr. A. G. Blair of New Brunswick, who was then Minister of Railways and Canals, introduced a bill to this end. ${ }^{2}$ Mr. Blair told the House that there was every prospect that the rail industry, " with a little proper and judicious encouragement," might be established in Canada. Hence the new clause in the subsidies bill making it a condition of the granting of a subsidy "that the company shall lay its road with new steel rails made in Canada, if the same are procurable

1 Cf. Montreal Star, April 27, 1901.

263.64 Vict. c. 58. 
in Canada upon terms as favourable as other rails can be obtained." Sir Charles Tupper strongly opposed the new provision, on the ground that it was contrary to freedom that promoters of railways should be told that they must place their orders for rails with some particular rail-making company, before they were granted a subsidy by the Government.

Mr. W. C. Edwards, one of the few surviving Liberal free trade members from Ontario, also protested on free trade grounds against this new concession to the "made in Canada" movement, and this speech from the Government benches elicited a defence of the new enactment from Sir Wilfrid Laurier. "I do not know," said the Premier, in answer to Mr. Edwards' free trade speech, "that I am guilty of any departure from the principles of the Cobden Club in this matter. It is no violation of the principle of free trade if we say to the man to whom we offer the bounty, 'you can have the bonus if you want it for the construction of your railway, but we make it a condition that if you can buy your rails in Canada at the same price as abroad, you should buy from a Canadian producer.'" 1

The two iron and steel plants at Sydney and at Sault Ste Marie have, from the time that the American promoters organised the companies for their installation, been prime favourites with the Government. The iron and steel bounty Act of 1899 was passed

1 House of Commons Debates, July 12, 1900. 
to help their promotion; and up to June 30 , 1906 , of the $\$ 8,814,835$ which since 1883 had been paid from the Dominion Treasury in iron and steel bounties, $\$ 3,466,519$ had gone to the Sydney Company, and \$988,443 to the Algoma Company, although it was not until 1901 that the Sydney Company came on the bounty list, and the first payment to the Algoma Company was not made until 1902.

It was June 1904 before an ingot could be rolled in either of these rail mills; but the Government was so anxious to get the company at Sault Ste Marie on its feet that on the eve of the general election in October 1900, it entered into a contract with Mr. Clergue to take annually for five years 25,000 tons of rails for the Intercolonial Railway. The contract of October 1900 was not made public until April 1901. In the first session of the new Parliament, when its terms became public-\$32.50 a ton for the deliveries of 1901, and deliveries in the four subsequent years to be based on prices for rails in England -it was regarded as a grave scandal; for the price for the 1901 deliveries was seven or eight dollars a ton in excess of prices prevailing in England and the United States at the time the contract was divulged.

The discussion on the contract extended over four sittings of the House of Commons; and not since the Laurier Government adopted the National Policy in 1897 had any step

1 House of Commons Debates, February 14, 1907. 
$\mathrm{CH}$.

taken to reduce the volume of imports occasioned it more trouble in and out of Parliament than its defence of the Clergue contract of October 1900. It was unfortunate for the Government that the contract had been made on the eve of the general election, and that its terms had been kept secret for six months. The debates on it in the House of Commons cover more than three hundred pages of Hansard. Sir Wilfrid Laurier, Mr. Fielding, and Mr. Clifford Sifton of Manitoba, who was then Minister of the Interior, went to the aid of Mr. Blair, the Minister of Railways. Neither Mr. Blair nor any of his ministerial colleagues took the ground that the contract was on a business basis-a contract such as the Canadian Pacific or the Grand Trunk Railway Company would have made. They all defended it on National Policy groundsthat it was expedient that adequate encouragement should be given by the Government to the erection and equipment of a steel-making plant in Canada. ${ }^{1}$ The House of Commons approved the contract and the spirit in which the Government had made it. The contract, however, was not fulfilled according to the terms of October 1900, because it was July 1904 before the rail-mill at Sault Ste Maric was ready for service. Both the rail-millsthat of the Dominion Iron and Steel Company and that of the Algoma Company-were at

' Cf. Canada's New Place in the Iron and Steel World, Connmercial Intelligence, June 1, 1901. 
work in July 1904; and in October 1903, in anticipation of these mills going into service, an Act was passed giving the Government power by order in council to impose a duty of seven dollars a ton on rails. "Such order," reads the Act, "shall not be passed until the Governor in Council is satisfied that steel rails of the best quality, suitable for use on Canadian railways, are being manufactured in Canada, from steel made in Canada, in sufficient quantity to meet the ordinary requirements of the market."

The rail plants have now been at work for two years. At no time prior to June 1907, when the open-hearth and Bessemer converter capacity at the plants was increased, did the output of the two mills for twelve months exceed 340,000 tons of rails $-180,000$ at Sydney and 160,000 at Sault Ste Marie. In the fiscal year ending June 30, 1905-the year that these rail-mills began work-Canada imported 185,660 tons of rails from the United States, and 24,140 tons from England, ${ }^{2}$ although in 1905 railway building was much less active than it was in 1906-7.

Within a month after the mills began work, the Government was satisfied that steel rails were being made " in sufficient quantity to meet the ordinary requirements of the market" ; and on August 27, 1904, steel rails were taken from the free list, and since then a duty of

2 Trade and Navigation Returns, 1905, p. 525. 


\section{PROTECTION IN CANADA сн.}

seven dollars a ton has been paid on rails imported from the United States. The duty on rails from Great Britain from August 27, 1904 , to November 30, 1906, under the preference, was $\$ 4.66$ a ton. Under the preferential tariff of 1906 the duty is $\$ 4.50$ a ton. On the pig-metal that goes into the steel ingots from which Canadian rails are made there is a bounty of $\$ 1.10$ a ton. This rate is to be maintained until the end of 1908 . In 1909 the rate will be seventy cents a ton; and until the end of 1910, when the legislation authorising these bounties may expire, it will be forty cents a ton. ${ }^{1}$

The iron and steel industry, as it exists in Canada to-day, is largely a creation of the Liberal National Policy of 1897-1907. It is true that the policy of granting bounties was begun in 1883 by a Conservative Government, and also that this policy was attacked with as much vigour by the Liberals as the protective tariffs of the Conservatives. But until 1897 the industry had made little progress. Only three furnaces came on the bounty list in 1883-4-a furnace of 125 tons capacity at

1 The plants at Sydney and Sault Ste Marie are on the lower scale of bounties because both use imported ores. Sydney draws its smpplies from Newfoundland; Sault Ste Marie from American mines in the Lake Superior country. Iron companies using Canadian ore receive on their output until the end of 1908 bounties at the rate of $\$ 2.10 \mathrm{a}$ ton; in 1909 the rate on pig-iron from Canadian ore will be $\$ 1.70$ a ton; and in 1910,90 cents a ton. On July 1, 1907, the daily capacity of all the blast furnaces in Canada on the active list was 2335 tons; but of this capacity only 310 tons was employed on Canadian ore. Cf. Canada's Iron Industry, Transcript, Boston, July 29, 1907. 
Londonderry, Nova Scotia, and two charcoal furnaces, with an aggregate capacity of 15 tons, at Drummondsville, Quebec. By 1896, when the Conservative Government went out of office, only three new producing plants had come on the list; and the total capacity of the five iron-making plants then in existenceLondonderry, Drummondsville, New Glasgow, Hamilton, and Radnor-was only 445 tons, 305 tons more than the aggregate daily capacity of the three furnaces that were in service when the bounty Act was passed in 1883, to help out the Londonderry Company, which was then in the hands of a receiver. In no year between 1883 and 1897 did the bounty payments exceed $\$ 125,000$; while in 1905-6 the payments were $\$ 2,400,773$; and on July 1,1907 , the daily capacity of furnaces on the active list was 2335 tons, with one furnace of 125 tons idle, and stacks under construction which will add 1100 tons to the furnace capacity of the Dominion.

From the first the Laurier Government has been quick to devise methods for aiding the iron and steel industry, and to act on suggestions like those of Mr. Clergue in 1900 for a large Government contract for the Sault Ste Marie plant, and for an amendment to the Railway Subsidies Act. The greatest impetus was given to the industry in 1897, when, in order to meet conditions at Sydney, the Government decided to pay bounties on iron from imported ores. Had this amendment 


\section{PROTECTION IN CANADA сн.}

to the bounty code not been made, it is doubtful whether the plants at Sydney and Sault Ste Marie would have come into existence; for there is no ore in the neighbourhood of either plant suitable for the economical production of Bessemer or open-hearth steel such as is now most in demand in Canada, and only the plant at Sydney is on a coalfield. For the fiscal year ending June 30, 1906, the output of the eight producing plants in Canada was 581,858 tons of pig-iron86,523 from native ore, and 495,335 from Newfoundland and American ore. The bounty payments on this output aggregated $\$ 687,632$, which practically covered the wages bill at the furnaces. ${ }^{1}$

It was to protect industries so built upindustries which had received aid from the Dominion, provincial and municipal governments - and in particular the wire-rod business of mills at Montreal and Sydney, that the dumping clause was embodied in the tariff in 1904. Wire rods are on the free list, as a bounty is paid on their production. In 1903 and 1904 the export company of the United States Steel Corporation was threatening the mills at Montreal and Sydney by the usual

1 The statistics as to bounties are from the Auditor-General's Annual Reports. For a detailed history of the bounties and of the development of the iron and steel industry in Canada since 1883, see article by present writer in Political Science Quarterly, June 1907. Particulars are there given of the largesse bestowed on the Sydney and Sault Ste Marie Companies by the Legislatures of Nova Scotia and of Ontario, and of the tax exemptions and other favours bestowed on these plants by the municipalities at Sydney and Sault Ste Marie. 
trust methods; and it was primarily to foil this attack that the dumping clause was enacted. Mr. Fielding, in submitting the new clause, explained that most of the dumping was by trusts and combines. "These trusts and combines," he told the House of Commons, "are not worrying about the good of the people of Canada. They send the goods here with the hope and expectation that they will crush out the native Canadian industries. And with the Canadian industry crushed out what would happen? The end of cheapness would come, and the beginning of dearness would be at hand. Ninety per cent of the complaints made to us by our manufacturers are not that the tariff is too low, but that this dumping and slaughtering exists." "The dumping condition," added Mr. Fielding, "is not a permanent condition. It is a temporary condition; and therefore it needs only a temporary remedy that can be applied whenever the necessity for it arises."

The clause intended to meet the conditions described by the Minister of Finance provided that wherever it appeared to the Customs Department that the import price, or the actual selling price to the importer, on any dutiable article of a class or kind made in Canada, was less than the fair market value, such article should, in addition to the ad valorem duty, be subject to a special duty equal to the difference between such fair

1 House of Commons Debates, June 7, 1904. 


\section{PROTECTION IN CANADA ск.}

market value and such selling price. The special duty was, however, not to exceed in general one-half of the ad valorem duty $\mathrm{On}$ some iron and steel imports, such as pig-iron, ingots, and blooms, structural steel and steel plates, this restriction was not imposed, but the dumping duty was not to exceed fifteen per cent ad valorem, "nor more than the difference between the selling price and the fair market value of the article." The clause as it stood between 1904 and 1906 applied only to articles on which duties were charged, except that as regards the free list it was applicable to wire rods not over three-eighths of an inch in diameter, on which the special duty was not to exceed fifteen per cent ad valorem. The expression "export price" was held to mean and include the exporter's price for the goods, exclusive of all charges thereon after their shipment from the place whence exported directly to Canada.

Mr. Fielding made it plain to the House of Commons that Canadian manufacturers had little to complain of as regards dumping by British exporters. "In low tariff countries, or in free trade countries, in Great Britain, for example," he said, "these disturbing conditions seldom exist. England conducts her business generally upon rational lines. She sells at a profit; and what is known as the system of dumping or slaughtering is hardly known in connection with British trade." ${ }^{1}$

1 House of Commons Debates, June 7, 1904. 
Several British Chambers of Commerce complained, almost as soon as the clause went into operation, of the onerous and complicated requirements as to details in invoices under the new regulations of the Customs Department at Ottawa. These complaints were investigated by the Liverpool Chamber of Commerce, and it was ascertained that they were well grounded. Representations were made to Lord Strathcona, Dominion High Commissioner in London, and in Jauuary 1905 he informed the Liverpool Chamber of Commerce that a minute had been passed by the Minister of Customs removing the grievances of which British exporters had complained. ${ }^{1}$

Many Canadian manufacturers, and especially those engaged in the secondary stages of the iron and steel industry, at once strongly objected to the new clause, and reiterated their objections to the Tariff Commission of 1905-6. But most Canadian manufacturers who appeared before the Commission were emphatic in commending it; and in the tariff of 1906 the clause was extended to all schedules, except where the duties are equal to fifty per cent ad valorem, to goods of a class subject to excise duty, to sugar refined in the United Kingdom, and to certain binder twines and fibres from which binder twine is made.

1 Cf. Fifty-fifth Annual Report of the Incorporated Chamber of Commerce of Liverpool ; and Witness, Montreal, November 19, 1804. 
Much credit was claimed for the Liberal Government at the general election in 1904 for "this important and striking departure in fiscal legislation." "Here again," reads a paragraph in "The Story of a Government that Does Things' - the Liberal Campaign Book for 1904, "the Government had to face changed conditions, requiring bold and drastic treatment. This [the dumping clause] is scientific tariff-making; this is businesslike treatment of a practical business proposition." 1

The amendment to the patent law was made in 1903. It has been as instrumental as the high duties on manufactured articles imported from the United States in compelling American manufacturers to establish branch factories in Canada - even more directly in many instances than the tariff. There are now one hundred and thirty of these factories. $^{2}$ Most of them are in Ontario and Quebec; and in Ontario it is a long-standing custom with municipalities to provide free sites, to give money bonuses, to grant loans and tax exemptions, and sometimes to give free water and electric light to these industrial newcomers. The bestowal of municipal largesse on industrial concerns in the Province of Ontario antedates the National Policy of 1879. It was one of the

1 Handbook of Canadian Politics, Illustrative of the Progressive Administration of the Laurier Government: The Story of a Government that Does Things. Issued October 1904.

2 Free Press, Winnipeg, July 1, 1907. 
arguments advanced by Macdonald in the House of Commons in 1876 to support his assertion that the people of Canada were prepared to make sacrifices for the National Policy. ${ }^{1} \quad$ Ninety-five Ontario municipalities had by 1900 granted aid in one form or another to factories-Canadian or Americanthat had been established in their areas." In the last seven years there have been scores of these municipal grants ; and in these growing times in Canada a week seldom passes in which paragraphs similar to those quoted below do not appear in the Toronto daily newspapers.

Chatham, Junc 5.-By 1271 to 91, 1025 being necessary for two-thirds majority, the Wolverine by-law was carried here to-day, largely owing to the strong support of the Board of Trade and the press. The proposition calls for a loan for twenty years of $\$ 20,000$ to Cornelins Bros., Grand Rapids, Mich., repayable $\$ 1000$ yearly. The city is secured by a mortgage and personal bonds of Cornelius Bros. The company will mauufacture brass goods and expects to employ 25 hands at the start, increasing in a jear to 100._Globe, June 6, 1907.

Sarnia, July 8.-Sarnia voted to-day upon two bonus by-laws, one to grant $\$ 12,000$ to the Standard Chain Company of Pittsburg, and the other to loan $\$ 12,000$ to the Jenks Dresser Bridge Company, both American concerns. On account of the large number of absentee rail. waymen and mariners, it was anticipated that there would be great difficulty in securing the requisite two-thirds of all the names on the list, and extraordinary efforts were made to carry the by-laws. Every automobile and vehicle available was secured, and some business houses closed up to allow the men to take part in the work. The result to-night shows that both

1 House of Commons Debates, March 10,1876.

2 Cf. Reports of Ontario Legislature, Globe, March 15, 1900. 
by-laws were carried by a sweeping vote. In place of the 1149 votes necessary, there was polled over 1666 for the Chain Company by. law, and 1635 for the Bridge Company by-law. The former company guarantees to employ not less than sixty men, and the latter fifty men.Globe, July 9, 1907.

Municipalities vie with one another in developing this local phase of the National Policy, and outbid one another in offering largesse to industrial promoters. ${ }^{1}$ Many Ontario municipalities have what is known as the industrial committee, whose duty it is, to quote the instructions to the industrial committee of the City Council of Hamilton, " to see that other municipalities do not offer better advantages to manufacturers than Hamilton does." 2 There have long been clauses in the municipal code of Ontario recognising the power of the municipalities to bestow largesse on industry. ${ }^{3}$

The Ontario custom was first adopted in Nova Scotia in 1879, in connection with cotton-mills at Halifax and Windsor ; ${ }^{4}$ and in 1883 the same custom was extended to New Brunswick, where, as in Nova Scotia, it was adopted in the interest of a cottonmanufacturing company. ${ }^{5}$ To-day, in Nova

${ }^{1}$ Cf. St. Catherine's despatch to Mail and Empire, Toronto, March 20, 1907 ; New Industries in Guelph, Globe, April 28, 1907 ; and speeches in Provincial Legislature against municipal largesse, Mr. Andrew Patullo, Globe, March 3, 1899, and March 16, 1900.

2 Hamilton Correspondence, Globe, April 29, 1907.

3 Statutes of Ontario, $2 \mathrm{Ed}$. VII. sections $591 \mathrm{~A}$ and $366 \mathrm{~A}$; also Revised Statutes of Ontario, 1897, section 411.

4 Statutes of Nova Scotia, 42 Vict. c. 27 ; 48 Vict. c. 50 ; and 62 Vict. c. 24.

- Statutes of New Brunswick, 46 Vict. c. 17. 
Scotia there is a general law under which all machinery in manufacturing plants and stock in the process of manufacture are exempted from taxation for any purpose, except schools, sewers, and municipal water-supplies. ${ }^{1}$

No enactment in the National Policy code has kept the industrial committees of Canadian town councils more constantly on the alert than the amendments to the Dominion patent laws in 1903; for one of the clauses in the amended Act makes a patent null and void at the end of two years " unless the patentee shall commence and continuously carry on in Canada the construction or manufacture of the invention patented, in such a manner that any person desiring to use it may obtain it at a reasonable price at some manufactory in Canada." Another clause decrees that "if after twelve months from the granting or authorised extension of a patent, the patentee imports into Canada the invention for which the patent is granted, such patent shall be void as to the interest of the person so importing." 2

Canadian retaliation against the German maximum tariff, which went into force against the Dominion in $1898,{ }^{3}$ began on October 24 , 1903. There then went into operation a surtax of one-third on imports from Germany. There is no mention of Germany in the Act

1 Nova Scotia Statutes, 63 Vict. c. 47.

23 Ed. VII. c. 46.

${ }^{3}$ Cf. House of Commons Debotes, January 9, 1907. 


\section{PROTECTION IN CANADA cr.}

imposing the surtax. Countries assailed by tariff legislation are never specifically named in either Canadian or United States retaliatory measures; for the courtesy of tariff wars seems to require that the punitive clauses mention no names, but be so drafted as to hit only the country aimed at. ${ }^{1}$ "Articles which are the growth, produce, or manufacture of any foreign country which treats imports from Canada less favourably than those from other countries," reads the clause in the Dominion enactment of $1903,{ }^{2}$ "may be subject to a surtax over and above the duties specified in the said Schedule $\mathrm{A}^{3}{ }^{3}$ such surtax in every case to be one-third of duties specified in the said schedule."

As German manufactured goods, or partly manufactured goods - notably textiles - are in some lines of industry the raw material of British manufacturers, and as under the preference these British-German goods before the tariff war began were admitted at the reduced rates when a "substantial portion" of their value consisted of British labour, it was necessary to include in the retaliatory Act of 1903 a clause governing this BritishGerman trade. "Such surtax," it reads, "shall apply to any articles, the chief value of which was produced in such foreign country, although it may have been improved

1 Cf. Dingley Act, 1897, item 195, sawn boards, and item 393, wood-pulp, and 3 Ed. VII. c. 15, clause 5, Dominion Statutes.

23 Ed. VII. c. 15.

${ }^{3}$ Schedule of goods subject to duties in tariff of 1897 . 
or advanced in value by the labour of another country, notwithstanding the provisions of the British preferential tariff, and the regulations thereunder."

Ministers have made several statements of the reasons for imposing the surtax. The most complete was that made by Mr. Fielding, when the tariff of 1906 was at committee stage in the House of Commons. In answer to a member who asked why the Dominion Government had applied the surtax when the German Government had applied only the maximum tariff to imports from Canada, the Minister of Finance gave a detailed account of the interchanges between the two Governments, which preceded Canada's retaliatory measure. "Canada," said Mr. Fielding, "had been on the minimum tariff, and Germany took exception to our action in giving a preference to Great Britain. We thought that was a very unfair act on the part of Germany. We did not deny to Germany favoured-nation treatment. We were willing to give to her every consideration that we gave to any foreign country. But she took offence because we would not treat her as we did the United Kingdom. We thought that unfair. We thought it was the result of misunderstanding on the part of Germany; that Germany thought we were treating her less favourably than we were treating other foreign nations. We endeavoured to explain first by correspondence through the usual 


\section{PROTECTION IN CANADA сн.}

official channels. We found that we could not reach the German Government rapidly through the ordinary official channels, so we prepared a memorandum of our case, and sent it to Mr. Bopp, German Consul-General in Montreal, asking him to lay it before his Government. We pointed out to him that the people were complaining of this unfairness, and that we were too patient in our treatment of Germany. We said, "We have given to Germany everything that we give to any foreign country; what we are giving to the French people, although they gave us valuable concessions in return and you did not. We think you should leave us where we have been for years.' The German Government did not do so. They still impose upon us the burden of their maximum tariff, and under these circumstances we adopted the surtax." 1

The general election of 1904 came exactly a year after the surtax went into operation, and the compiler of the Liberal Campaign Book bestowed even more laudation on the surtax than on the dumping clause. Germany, he asserted, had attempted to intimidate Canada by applying to her produce the maximum tariff; "because, forsooth, we have given a preference in trade to our Mother-land." "Such a position," he continued, "was, of course, absurd for a country like Germany to take; but notwithstanding the protests of our Government they maintained it. Every

${ }^{1}$ House of Commons Debates, December 14, 1907. 
possible effort was made by our Government to get the Germans to take a more reasonable view, but without avail; so retaliation was resorted to, a stiff surtax of one-third the ordinary customs duty being imposed. Here again the Government scored a triumph not only for Canada, but for the whole British Empire. ... The trade of Germany with us has fallen off fifty per cent since the surtax was imposed. The German attitude was an attempt to thwart the movement for preferential trade relations within the Empire, which, if submitted to, would perhaps have been the death-blow to the movement.

Not all Canadian manufacturers endorsed this eulogy of the surtax. This "excellent Canadian Roland for the German Oliver" which, within a year, according to the Campaign Book, reduced imports from Germany by fifty per cent, did not meet with universal approval. At the sessions of the Tariff Commission in 1905-6 makers of women's hats complained that the felt in fashion at that time was not to be obtained except in Germany; and told of their inconvenience and loss in searching for substitutes. Importers of knitted woollen goods and of women's cloaks assured the Commission that they had also experienced dislocation of trade and loss from the surtax.

Conditions in many lines of business calling

${ }^{3}$ Handbook on Canadian Politics: The Story of a Government that Does Things, p. 39. 
for German goods were such that in 1905-6 $\$ 550,000$ was collected as surtax, ${ }^{1}$ a burden which, of course, fell wholly on the consumer, and which was much heavier than is indicated by the figures, for the jobbers' and retailers' profits on this sum of $\$ 550,000$ must be added, to ascertain the monetary cost of this little tariff war. ${ }^{2}$ Canada certainly was not the aggressor; but that Canada merely retaliated was a poor satisfaction to the business men whose trade was dislocated, and to the consumer on whom the burden of the surtax ultimately fell.

It is always the same in tariff wars. It was the manufacturers who jeopardised the reciprocity treaty of $1854-66$, but it was the farmers, the lumbermen and fishermen who suffered when the treaty came to an end. It is the farmers and fishermen of the Dominion whose markets have been curtailed since 1898 , when Germany imposed her maximum tariff on imports from Canada. It is the farmers and fishermen who carry the chief burden of the surtax; and it is the manufacturers who most enthusiastically endorse its imposition, who dread the day when the tariff war shall come to an end.

1 Cf. House of Commons Debates, December 14, 1906.

${ }^{2}$ Mr. John Bain, who was Deputy Minister of Customs at Ottawa until 1907, informed the Tariff Commission at Quebec on December 28,1905 , that in the preceding fourteen months-October 1904 to November 1905 - cloaks of the value of $\$ \$ 5,000$ that had come from England had been surtaxed because they were of German woollens. More than half of the total importations of cloaks in 1904-5, Mr. Bain added, were from Germany, and paid the surtax. 
The protected manufacturers invariably endorse any scheme or plan that will forward the aim of the National Policy as expounded by Tilley when he was Minister of Finance in 1879. Both the surtax for Germany and the proposal originating at St. John, New Brunswick, in 1898, that the British preference shall be denied to all imports that do not reach Canada by Canadian ports, have had the endorsement of the manufacturers; and in the early summer of 1907, when the Premier and the Minister of Finance were in Europe, and there were rumours of a reapproachment at Berlin, ${ }^{1}$ the executive council of the Canadian Manufacturers' Association showed extreme nervousness lest an arrangement might be made with Germany that would end the tariff war, and that might also give to her exports the slight advantage of the intermediate tariff of $1906 .{ }^{2}$

While these important departures were in making between the tariff revision of 1897 and that of 1906, in vigorous pursuance of the policy-now of nearly thirty years' standingof legislation to reduce imports, the interests

${ }^{1}$ Cf. Concessions by Germany, Globe, May 21, 1907.

2 The Chairman, Mr. W. K. George, presented the report of the Tariff Committee. It referred to the despatches current in the press to the effect that negotiations were under way between Canada and Germany for mutual tariff concessions, and stated that, after carelul investigation, the Committee was satisfied that these reports were withont foundation. Should it be ascertained later on that the Government was serionsly contemplating such arrangements, the Committee wonld take up the matter vigorously.Report of monthly meeting of the Executive Council of Canadian Manufacturers' Association at Toronto, May 16, 1907 ; Industrial Canada-the offecial organ of the Association-June 1907. 
of general consumers, on whom the burden of the tariff falls, were not entirely overlooked by the Government. "Molasses," to quote once more from the Liberal Campaign Book, "an article largely used, particularly by the working classes, which was dutiable at oneand-three-quarter cents per gallon, was placed on the free list when imported from the British West Indies." 1

Moreover, by the Amending Act of 1904, by which this concession was bestowed on the molasses-consuming population, the duty on coal-oil was reduced from five to two-and-ahalf cents a gallon-the Ontario oil refiners being duly compensated by a bounty of oneand-a-half cents a gallon from the overflowing Dominion treasury. ${ }^{2}$ The duty on paraffinwax candles, which had stood at thirty per cent since 1897 , was reduced to twenty-five per cent; a similar reduction was made on paraffin-wax, used by housewives in the jammaking season; and whale-oil soap and artificial teeth were put on the free list. In this way, and to this extent, in the period between the enactment of the tariff of 1897 , and November 1906, there was some fulfilment of the Liberal pledge of 1893 that "the tariff should be so adjusted as to make free, or to bear as lightly as possible, on the necessaries of life." "s

1 Handbook on Canadian Politics, p. 41.

2 The surplus in 1904 was $\$ 15,056,984.12$.

s Ottawa Liberal Programme, 1893. 


\section{CHAPTER XIII}

\section{THE TARIFF REVISION OF 1906}

THE customs tariff of the Dominion should be based, not, as it is now, upon the protective principle, but upon the requirements of the public services. The existing tariff, founded upon an unsound principle, and used, as it has been by the Government, as a corrupting agency wherewith to keep themselves in office, has developed monopolies, trusts, and combinations.-Ottawa Liberal Programme, 1903.

THE recent revision of the tariff will, it is believed, meet with the general approval of the trade, removing, as it does, many inequalities heretofore existing.Speech from the Throne, 1907.

I HOLD we have just as good a right to use the tariff to defend the country against the invasion of foreign goods as we have to call out the militia to defend it against the invasion of an armed force.-Mr. Davrd Henderson, M.P. for Riding of Halton, Ontario.

In March 1876, when Macdonald, then the leader of the Conservative Opposition, proposed his first National Policy resolution, he told the House of Commons that the object of this policy was to render the Dominion independent of foreign countries and reduce imports from England and the United States. ${ }^{1}$

${ }^{1}$ Cf. House of Commons Debates, March 7, 1876. 
The policy thus enunciated was persistently and vigorously forwarded by the Laurier Government between 1897 and 1904, culminating in the enactment of the amendments to the tariff in 1904 by which there was the first curtailment of the British preference, and by which also dumping was penalised. Thus it was easy for the Canadian Manufacturers' Association to key its policy to that of the Government, and to put vigour into the campaign begun in 1900 for another general revision of the tariff in a protectionist spirit.

Trade was well on the up-grade in 1902, but it was asserted by the Association that conditious in Canada had changed between 1897 and 1902 ; and a resolution was adopted at the Halifax Convention, in which it was declared that these changed conditions demanded "the immediate and thorough revision of the tariff, upon lines which will more effectually transfer to the workshops of our Dominion the manufacture of many of the goods which we now import from other countries." The resolution also affirmed that while such a tariff should primarily be framed for Canadian interests, "it should nevertheless give a substantial preference to the Mother-country, and also to any other part of the British Empire with which reciprocal preferential trade can be arranged, recognising always that under any conditions the minimum tariff must 
afford adequate protection to all Canadian producers."

Two years before the Halifax Convention, the "made in Canada" movement had been started; and as early as November 1900 it had been suggested that the Canadian Manufacturer's' Association could do effective work by "undertaking some systematic movement to cultivate patriotism among the people of Canada in the matter of giving home goods the preference." 2 One of the earliest demonstrations in support of the new movement was at the Toronto Industrial Fair, in the autumn of 1901, when several manufacturers attached cards to their exhibits, on which were the words "Made in Canada." "This," said the organ of the Manufacturers' Association, in commenting on the exhibits, "is a step in the right direction-one that we have desired to see taken for many years." 3

At the Halifax Convention the Manufacturers' Association raised a special fund to push this new educational movement. It was from this fund that the cost was defrayed of printing and distributing millions of adhesive stamps, ${ }^{4}$ which were placed on letters and packages going through the post office, on manufactured goods and merchandise, and, so long as the fad lasted, on anything that

1 Cf. President's Address at Convention of Canadian Manufacturers' Association, Quebec, News, Toronto, September 19, 1905.

${ }^{2}$ Cf. Letter by Mr. D. W. Buchanan, quoted in Industrial Canada, November 1900.

3 Industrial Canada, October 1901.

* Cf. Canadian Manufacturer, January 4, 1907. 
offered. Two of these pasters were in service: one to work up the "made in Canada" sentiment; and the other, that the Association might not seem lacking in the Empire spiritin the interest, in a limited and qualified degree, of the British preference.
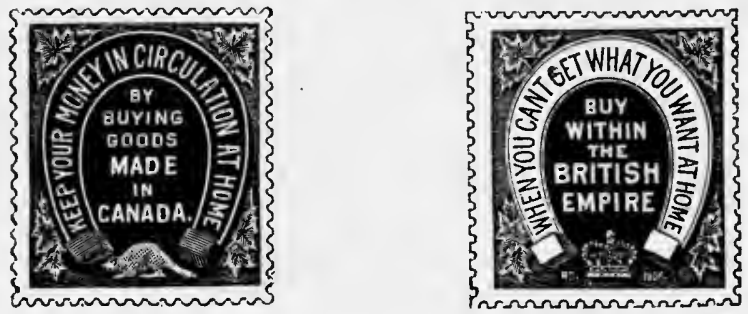

The agitation for the revision of the tariff was pushed as part of the "made in Canada" propaganda. Both were exclusively movements of the Manufacturers' Association. The movement for a protectionist revision of the tariff, as was evident when the Tariff Commission went on its tour from the Atlantic to the Pacific in 1905-6, had no popular support outside the ranks of the manufacturers. It certainly would never have had any success, would never have been formidable to the Government, had it not been for the pertinacity with which between 1902 and 1904 it was worked, not by the whole Association, but by a group of extreme protectionists who were of the tariff committee, ${ }^{1}$ who by their

1 Cf. The Tariff, Canadian Manufacturer, January 4, 1907 ; Witness, Montreal, January 16, 1907. 
persistence succeeded in securing the political support of ultra-protectionists on both sides of the House of Commons. ${ }^{1}$

The Dingley tariff, brutal as was the havoc it made in the lumbering and farming industries in Canada, inflicted no hardship on Canadian manufacturers, except those engaged in saw-milling and in the manufacture of paper from wood-pulp. No other Canadian manufacturer lost any business as a result of the United States tariff of 1897 ; but from 1901 until the Dominion tariff was revised in 1906, Canadian manufacturers were clamouring for higher duties in retaliation for the Dingley Act. Almost any excuse can be made to serve as a plea for more protection; and the extreme protectionists, indifferent as to where the burden of a tariff after the American model would fall, made the most in the agitation for tariff revision of the high duties that since 1897 have been levied under the Dingley Act.

Many of these extremists urged the enactment of a Canadian tariff, with duties all through the schedules on the Dingley scale, in the hope that by such a tariff there would be an increase of the duties under the British preference. Notwithstanding the commendation of trade with Great Britain in the "made in Cauada" propaganda, there were active and prominent members of the Manufacturers'

1 Cf. Speech by Mr. Archibald Campbell, M.P., Montreal, February 27, 1902; and speech by Mr. J. I. Tarte, then Minister of Public Works, at C.M.A. banquet at Halifax, Angust 15, 1902. 


\section{PROTECTION IN CANADA сн.}

Association who made no concealment of their dislike of the preference. "I am sure," said Mr. J. F. Ellis, who was President of the Association, at Toronto, in 1901, "that it is the opinion of Canadian manufacturers that the duty of the Government is to legislate first for Canada, and for Great Britain afterwards. In other words, that the preference should give the British manufacturer a substantial advantage over his foreign competitor, but not over the Canadian; and that when any Canadian industry has suffered, attention should be given promptly and fairly." 1

"There can be no doubt," asserted Industrial Canada in May 1902, "that the present condition of international trade warrants a change in the Canadian tariff; and while the efforts made by the Association for a general revision have not yet been successful, we believe that the united action of the manufacturers, backed by the increasing tide of public opinion, will before long convince the Government of the necessity for reform." "The British preference," urged Industrial Canada in March 1904, "up to now has not been of material advantage to Canada. It has not helped the manufacturers, farmers, lumbermen, or any class of our people. Some branches of industry it has injured seriously." " "Canadian manufacturers," de-

1 Industrial Canada, November 1901.

2 This article appeared before the Government had readjusted the preference on British woollens by the amendment to the tariff of 1904 . 
clared this official organ of the Manufacturers' Association, in the issue for May 1904, "do not favour the sacrifice of Canadian industries for the sake of a preference in the British market."

Earlier than this statement of May 1904, at the end of 1903, when the Manufacturers' Association defined with some detail its case for the revision of the tariff, it was insisted that such a revision was imperative in order that capital and labour in Canada might be properly protected from specialised and heavily protected industries of foreign countries, which used Canada as a dumping-ground; that Canada's resources might be developed and industries built up; and that the surplus requirements of the Canadian market - the demands that Canadian manufacturers could not fill-might be supplied from British rather than foreign sources. In this manifesto of 1903 the Association declared that it did not advocate the adoption of the United States tariff, because while some industries in Canada required as much protection, some required less ; but it was insisted that the tariff should be framed from a national standpoint, and above all that it should be so devised as to enable Canadian products to meet the competition of foreign labour on fair and equitable terms. ${ }^{1}$

The Government capitulated to the Manufacturers' Association in the Parliamentary session of 1904. Industry in Canada was

${ }^{1}$ Cf. Industrial Canada, January 1904. 
then even more prosperous than in 1902 , when the Association made its first demand for a revision of the tariff. Manufacturers were as fully employed as they are in 1907. In the United States in 1904 manufacturers and protectionist politicians were content to "stand pat," and to hold their own against the movement in Congress for a reduction of the duties in the Dingley Act. But by 1904 the Conservative Opposition had taken up the movement of the Manufacturer's' Association for higher duties, and in October there was to be a general election. Under these conditions the Government deemed it expedient to commit itself to revision, and the announcement of its surrender was made in terms which gave the fullest satisfaction to the Manufacturers' Association-for these terms foreshadowed (1) a maximum tariff for countries such as the United States and Germany, which impose high protectionist duties against Canada; (2) a minimum tariff for countries such as Holland and Belgium, which have tariffs for revenue only; and (3) a preferential tariff for Great Britain and the numerous British colonies which since 1897 had received favourable treatment in Canadian tariff legislation.

Said Mr. Fielding on June 7, 1904, when he announced that the tariff of 1897 was to be revised:

We have to-day practically a maximum and a minimum tariff, if I may so describe it; and then we 
have the British preference below that again. It would be well that in the revision that may take place we should adopt that principle as it now exists and deal with it more in detail. I think it would be well for us to have a maximum general tariff and a minimum general tariff, and the British preference below that as we have it to-day. The maximum tariff would be only applied to those countries which pursue, if I may so call it, a hostile policy. I do not mean to say that they have any hostility to us, but that simply in the carrying out of their own affairs they adopt a trade policy which discourages trade with us. In that case they cannot complain if we have a maximum tariff, and though we should guard against having an extreme tariff, we should be justified in saying that this tariff should be materially higher than the tariff which we are prepared to extend to other countries which are willing to trade with us on fair and reasonable terms.

The minimum general tariff, which would correspond to the general tariff to-day, would apply to such countries as do not legislate commercially in a spirit of hostility to us-perhaps that is not happily expressed, - let me say to countries that adopt more moderate tariff views: low tariff countries.

Of course, where there are favoured nation treaties in existence they have to be considered; but the principal natious which to-day adopt a high tariff policy have not any favoured nation arrangement; and therefore I think our hands will be free in that respect. So we would have a maximum tariff, as we have the German surtax to-day, to apply to such countries as do not manifest a disposition to trade with us.

We should have a minimum general tariff to apply to countries that are disposed to trade with us, and then below that we would have the British preferential tariff to apply to the Mother-country and to such colonies of the Empire as it may be expedient to extend the benefit of that tariff to. I think that on this line, 
$\mathrm{CH}$.

guarding carefully against extortionate duties, but also making a distinction between the countries which wish to trade with us and the countries that do not wish to trade with us, we can devise a tariff which will be in all its details fairly satisfactory to the country.

At the general election in October the concession to the Manufacturers' Association by the Minister of Finance dished the Conservatives, who then, as now, had no policy except higher duties in the tariff. The protected manufacturers, with Mr. Fielding's speech of June 7 in mind, saw visions of a Dingley tariff for Canada; and these exhilarating expectations of retaliation against the United States, which would add enormously to the duties in the manufacturing schedules, and at the same time increase the duties on British imports, were kept alive by the speech which Mr. Fielding made in the session of 1905, when he announced that there was to be a ministerial commission to revise the tariff. The Minister of Finance then read to the House his speech of June 7, 1904-the speech here quoted-and asserted that the House and the country had accepted it as expressing the spirit in which the tariff of 1897 was to be revised. The Manufacturers' Association had unquestionably so accepted it, and manufacturers were soon preparing their campaign before the 'lariff Commission in the expectation of a tariff on the Dingley model. ${ }^{1}$

1 Cf. House of Commons Debates, June 10, 1905. 
The Tariff Commission, of which Messrs. Fielding, Paterson, and Brodeur were the members, began its work with a preliminary sitting at Winnipeg on September 7, 1905; and the last of its sixty-seven public sessions was at Ottawa, on February 9, 1906. Until as late as the session at Toronto on November 14, 1905, the commissioners held to the plan of revision that Mr. Fielding had laid before the House of Commons. "There will be," Mr. Fielding explained, at Toronto, "a maximum general, a minimum general, and the British preference, with latitude to fix the preference at rates from ten to fifty or seventy-five per cent, as conditions demand." But there was a farmers' day at Toronto after this third exposition by the Minister of Finance of his policy. There were other farmers' days, when the Commission visited London, Chatham, Hamilton, and Brantford; and still more farmers' days, when in December the Commission was in Manitolia and the new western provinces; and the opposition of the farmers to an increase in the duties on imports from the United States was so outspoken and so persistent that not another word was heard from the Tariff Commission, or any other member of the Laurier administration, of a maximum tariff to be applied to imports from the United States. ${ }^{1}$

The scheme which Mr. Fielding had so

${ }^{1}$ Cf. Speech of Mr. R. L. Borden, House of Commons Debates, December 4, 1906. 
carefully elaborated in June 1904-the scheme which had raised such exhilarating expectations among the protected manufacturers and the ultra-protectionist politicians at Ottawa -was quietly abandoned by the Government sometime between the session of the Tariff Commission at Toronto, on November 14 , 1905 , and the introduction of the new tariff on November 29, 1906. It was killed by the steadfast and well-organised opposition of the Dominion Grange, the Ontario Farmers' Association, and the Manitoba Grain-Grower's' Association to any higher duties either against Great Britain or the United States. It was a hastily-conceived and ill-considered scheme. It died, lamented only by the Manufacturers' Association; to whose surprise and disgust there was substituted for it the innocuous intermediate tariff, with ten per cent off the duties in the general list for countries whose tariff system can comply with its conditions.

Innocuous as the intermediate tariff ispossessing as it does scarcely more than academic interest-the Manufacturers' Association for six months after it was enacted was in dread lest it might be applied to the United States and Germany ; and this nervousness was not allayed until Sir Wilfrid Laurier made the announcement in England that it was never intended to apply the intermediate tariff to the United States, and news was sent out from Ottawa denying the statements in the press of Berlin of April 30, 1907, that 
the intermediate tariff was to be made applicable to that country. ${ }^{1}$

It was my good fortune to travel for seven weeks with the Tariff Commission in the provinces of Ontario, Quebec, New Brunswick, and Nova Scotia. Describing its procedure and work on February 19, 1906, when the public hearings were at an end, and the supplementary private interviews between ministers and tariff beneficiaries at Ottawa, which went on until the new tariff was at committee stage in December 1906, had not yet commenced, I wrote :-

The Commission went to the people. It began work on the Pacific Coast in the early days of September 1905 , and worked its way across the continent from Vancouver and Victoria to St. John, Charlottetown, Sydney, and Halifax, where its hearings came to an end on the 30th of January. The Commission had to zigzag across the continent; often to double back in its journeys. The ministers spent most of their nights on a railway car, equipped to serve both as a home and an office; and in fulfilment of their policy of giving everybody interested an opportunity of a hearing, they travelled fourteen thousand miles, and held sessions in between fifty and sixty towns.

All the sessions were open to the public; and due notice that they were open, and that everybody was entitled to a hearing, was given in advance-sometimes by poster, sometimes by advertisement in the local press-in every town and city that the Com-

1 Cf. Ottawa Correspondence, Globe, May 1, 1907 ; Industrial Canada, June 1907. "There seems," wrote the Ottawa correspondent of the Globe, "no indication of any application within the near future of the intermediate tariff to German imports into Canada." 


\section{PROTECTION IN CANADA сн.}

mission visited. Reporters and newspaper correspondents were in attendance at every session. Any man who cared to send in his name to the Secretary of the Commission, that it might be entered on the schedule of petitioners, was given a hearing. An American appearing before the Commission had onlylike a Canadian-to produce his type-written statement or petition; read it to the Commissioners, and then submit, just like the Canadian witnesses, to a pretty searching examination and cross-examination from the Commissioners' side of the table.

Early in the long tour there were witnesses who would have liked to talk with the Commissioners in private, and other witnesses who desired to submit data in confidence. But, when a witness was disposed to lower his voice, and talk only for the ear of the Commissioners, he was promptly told by Mr. Fielding, the President of the Commission, to speak up, so that the newspaper correspondents might hear; and except as regards such matters as actual workshop costs, which were only occasionally offered, the Commissioners refused to accept any confidential data. These open-door methods added enormously to the work of the Commission; as manufacturers who were assailed at one town turned up at another with statements in rebuttal.

High-protectionist manufacturers urging more protection against the United States and Great Britain; farmer deputations anxious to bring the Liberal party of Canada back to its policy of Opposition days of a "tariff for revenue only"; academic free traders; advocates of single tax ; and supporters and opponents of Mr. Chamberlain's propaganda for inter-imperial trade, based on a return to the protective system in Britainall availed themselves of the sessions of the Commission; and in some cities the pressule of work was so great that the sessions were prolonged until midnight. ${ }^{1}$

1 Canada's Tariff Mood towards the United States, North American Review, April 1906, pp. 566, 567. 
Four aspects of the public proceedings of the Tariff Commission of 1905-6 are of permanent significance in the history of protection in Canada. (1) The demands made by hundreds of manufacturers at the height of a long-extended period of unexampled industrial prosperity for higher duties than those in the tariff as it stood after the amendments made in 1904, and the grounds on which those demands were made; (2) the attitude of the farmers and manufacturers towards the preference for Great Britain ; (3) the attitude of the farmers towards the protectionist system and towards the protected and bounty-aided manufacturers; and (4) the attitude of the people of Canada towards Mr. Chamberlain's scheme of 1903 for British preferences for Canadian and other colonial products.

During the course of thirty-three years of newspaper work-half of it as special correspondent-it has been my lot to see much of the best and most inspiring sides of life, and some other phases that are saddening. But nothing in my contact with the reverse side of the shield has been more depressing than one constantly recurring phase of human frailty that presented itself before the Tariff Commission. Canadian manufacturers have now been protected against competition for nearly thirty years, many of them since as far back as 1858-59. Scores of them during this period have been permitted to name the amount of protection they wanted. Canada, 


\section{PROTECTION IN CANADA сн.}

as I have said, was rompingly prosperous in 1905-6. There were evidences of prosperity wherever the Commission went, and admissions of it from the manufacturers whenever the Commission asked for them. There was also at that time a tariff which gave a protection ranging from twenty to thirty-five per cent; and from the Dominion Treasury in 1905-6 bounties to the iron and steel industry, and to two or three less important industries, were being dispensed at the rate of nearly two and a half million dollars a year. ${ }^{1}$ Factories everywhere were in arrears with their orders; and in the period that had elapsed since the tariff revision of 1897 prices had advanced so much that whereas in 1897 the expenditures of a family of five, living in Ottawa, on an income of $\$ 1200$ a year, for rent, fuel, food, clothing, light, and servant, could be met for $\$ 77.50$ a month, by $1907 \$ 100.50$ was required to meet these outgoings. Prices had increased by thirty per cent. ${ }^{2}$

For most manufacturers this increase in prices meant that their actual protection in the ad valorem schedules of the tariff was much greater than the figures indicated. Yet with all these conditions in their favour, with every even fairly well-managed industrial plant earning money for its owners at a rate without precedent in Canadian economic his-

1 The exact sum was $\$ 2,400,771$, Auditor-General's Report, 1905-6, p. 781 .

2 Cf. Memorial of the Civil Service Association, Ottawa, June 26,1907, p. 17. 
tory, manufacturers, reeking with prosperity, appeared before the Tariff Commission, and unblushingly demanded an increase of seven and a half on this item and ten per cent on that. These demands were made as of right, regardless of the fact that there are men and women behind dollars; that dollars must be earned; that earning means toil ; and that the average income of a wage-earner in industrial Canada in 1905 was only $\$ 419$ a year. ${ }^{1}$

In the National Policy period of 1879-1896 it was a complaint with the Liberals that the protected manufacturers always pulled a poor mouth when a revision of the tariff was in sight. "These infant industries," said Mr. A. H. Gillmor, a Member of Parliament from New Brunswick, at the National Liberal Convention in 1893, "are like the fatted calf, always sucking; and they never will get weaned. These infants are never ready to have their protective tariff taken off. You suggest a reduction of tariff to them, and they look so lean and miserable that you would pity them from the bottom of your heart. But when they feel that the tariff is safe for them, they swell to enormous proportions, and display their carriages and footmen, and their eyes stick out with fatness."

The poor mouth was seldom pulled at the sessions of the Commission; and while I was

1 Cf. Bulletin of Census Bureau on Wage-Earners of Canada, issued July 19, 1907 ; Globe, Toronto, July 20, 1907.

2 Official Report, Liberal Convention, 1893, p. 53. 
with it the infant industry plea was not urged more than two or three times. It was impossible for men interested in iron and steel undertakings like that of the Dominion Company, which is capitalised at thirty-five million dollars; or that of the Nova Scotia Company, capitalised at nearly ten million dollars; or in cotton manufacturing concerns like the Dominion Textile Company, capitalised at eight million dollars; or the Montreal Conpany, at four million dollars; or in woollenmanufacturing concerns like the Penman Company, capitalised at four million dollars-it was impossible for managing directors of tariff-buttressed and bounty-fed concerns like these to appear before the Commission and file the infant industry plea.

One of the most significant developments of the tariff revision of 1905-7, in fact, was the almost complete disappearance of the infant industries plea, which had been of the protection propaganda since the days of Isaac Buchanan and the Association for the Promotion of Industry in Canada of 1858. But the prosperous captains of industry in 1905-6, the managing directors of concerns of enormous capital such as I have described, and men in lesser industrial associations, or in individual enterprises, were not at a loss for pleas.

A director in one of these great concernsan agricultural implement-manufacturing company-asked for more protection to enable his firm to extend its export trade, and told 
the Commission that it was unreasonable of the farmers to object to high duties on American farm implements, for his factories offered opportunities to farmers' sons of becoming skilled artisans. The representatives of the largest stove-making plant at Hamilton sought an increase in the duty on stoves, to close the Canadian market absolutely against cheap stoves that were going from Minneapolis and St. Paul to settlers in the new west; and a similar plea was put in by a company, also at Hamilton, which in association with another enterprise at Three Rivers, Quebec, controls the manufacture of coffins in the Dominion. A director of one of the largest cotton-mill companies, in whose interest the tariff was increased in 1897, asked for more protection both against England and the United States.

The plea for more protection against England was based on a statement that Manchester merchants at the end of the season dump printcloths in Canada. In support of his case the managing director of one of these cotton companies drew a gloomy picture of conditions at Valleyfield in 1903-4. Only part of the equipment there was at work; what he described as the "mill help" was scattered, retail stores were closed, and hundreds of tenements were empty. All these conditions were attributed to the inadequacy of a protection of thirtyfive per cent against New England, and to the ease with which Lancashire cotton manufacturers could scale a tariff wall only twenty- 


\section{PROTECTION IN CANADA сн}

three-and-a-third per cent high. Information, such as any well-informed cotton man must have possessed, as to the existence of similar depressed conditions at the same time in Lancashire and Massachusetts-mills on halftime and soup kitchens in some of the Lancashire towns; and two and three-quarter million spindles and seventy thousand looms at Fall River idle for four months in the autumn of 1904 -all due to raw cotton at sixteen and seventeen cents a pound, was carefully withheld from the Commission.

One plea that was substituted for the infant industries cry was that it was essential that Canadian manufacturers should have increased protection to enable them to specialise according to American methods. Another was that should the tide of prosperity turn more protection would be necessary to guard against cheap imports. But the plea most frequently pressed was that as Canadian industries had come into existence under the protection of the tariff, it was incumbent on the Government so to increase this protection that the whole trade of Canada should be reserved exclusively for Canadian manufacturers. "We are Canadians," said a stove manufacturer who advanced this plea at Hamilton, "and we ought to have all the Canadian business."

Members of the Canadian Manufacturers' Association presented their pleas when the Tariff Commission was in their neighbourhoods, and at the final sessions of the Com- 
mission at Ottawa the Association presented its general case for higher duties. "We desire to make in Canada," read this memorial, "everything which can reasonably be manufactured here; and to buy our surplus requirements, so far as it is reasonable to do so, from British sources. To this end we desire a higher tariff than we now have against all foreign countries. While we do not favour any discrimination against the United States as compared with other foreign countries, yet the proximity of the great republic, with its gigantic combinations of capital, its keen business men, and its constant surplus production, subject the manufacturers of Canada to competition, which, unless properly safeguarded, means certain ruin." I

At every session of the Tariff Commission at which the farmers made an appearance the preference for Great Britain was enthusiastically commended; and the farmers and importers of textiles in Montreal and Toronto were urgent in their pleas for the repeal of the amendment of 1904 to the Tariff Act which curtailed the preference, and the restoration of the uniform reduction of one-third of the duties on all British imports. The furmers commended the preference because it afforded some relief from the tariff, and because it served as a tie to the Mother-country. They realised that as a result of the good feeling towards Canada created by the preference,

1 Memorial of Canadian Manufacturers' Association, p. 10. 


\section{PROTECTION IN CANADA сн.}

Great Britain gave a sentimental preference to Canadian products, and that they had a ready market in England for all their produce.

On the other hand, it is difficult to recall a single session of the Commission in industrial Canada at which the preference was not attacked by the manufacturers in the spirit of Mr. Ellis's speech at Toronto in 1901, when President of the Canadian Manufacturers' Association. In honour of the Commission's visit to Valleyfield, the superintendent of the cotton company which has its mills in the industrial Venice of Canada-mills for which power is generated by the magnificent canal from the St. Lawrence-ran up the Union Jack over the spinning mill, and straightway went before the Commission with a plea for increased duties in the cotton-schedules to reduce imports from Lancashire. Some time before this patriotic demonstration at Valleyfield, on December 26, 1905, the same plea in the interest of the same mills had been adranced before the Commission at Montreal ; and during the week that the Commission was in Toronto, Mr. Ellis, an ex-president of the Manufacturers' Association, who is a manufacturer of jewelry, urged an increase in the duties on jewelry from England.

Mr. Brodeur, then Minister of Inland Revenue, the statistician of the Commission, and adept at always turning up import figures at the psychological moment, called Mr. Ellis's attention to the fact that in the preceding 
year only $\$ 56,000$ worth of jewelry had been imported from Great Britain. But Mr. Ellis had a revelation to make to the Commission. He had discovered that British manufacturers of inexpensive jewelry, stimulated by the preference, were adopting American designs to meet popular taste in Canada. Formerly British jewellers had ignored the Canadian market, but Mr. Ellis had ascertained that designers from British factories had recently been in Canada to study Canadian taste. Travellers from these British houses had even been seeking orders; and it was to ward off this threatened competition that $\mathrm{Mr}$. Ellis asked-not without success-for an increase in the duty on these British imports.

The case thus presented for a curtailment of the preference was supported by the Gold and Silversmiths' Association of Canada, which also supported similar pleas made by manufacturers of plated and sterling silverware. Mr. W. K. George, who was President of the Canadian Manufacturers' Association when, in 1905, it made its visit to England, urged higher duties on silverware to protect Canadian manufacturers from the low wages paid in Sheffield and other centres of the trade in England. The maximum wage in the industry in England, he informed the Commission, was thirty shillings a week, as compared with fifteen dollars, the average wage in the silverware factories in Toronto. At London manufacturers of wood screws asked for higher 


\section{PROTECTION IN CANADA сн.}

duties against England to prevent dumping from Birmingham; and a local manufacturer of pickles asked for a change in the preference to protect him from the competition of bottled olives from what, in this part of Ontario, is always spoken of as "Old London."

When the Commission reached Windsor, a city that is divided from the State of Michigan by the Detroit river, a manufacturer of blankets loaded down the table in the courthouse with samples of his product. He proved to the satisfaction of the Commission that they were all wool, and he insisted that he must have at least thirty per cent to protect him from shoddy and adulterated blankets from Lancashire and Yorkshire, or he would be compelled to close his mills. At Three Rivers, on the north shore of the St. Lawrence, still another charge of dumping was made against British manufacturers. 'This time it was the makers of cast-iron water-pipes at Glasgow who were named as the offenders. Manufacturers of felt and straw hats at St. Hyacinthe, Quebec, demanded higher duties against the Stockport, Denton, and Luton factories.

There is no duty on tea; but at St. John, New Brunswick, the wholesale tea merchants asked for a duty on tea in packages, to transfer the business of blending and packing from London to Canada's winter port. At St. Croix, a New Brunswick tide-water city that is separated from Calais, in the State of Maine, by the St. Croix river, owners of granite 
quarries urged a curtailment of the British preference on tombstones to protect them from the pauper labour of Aberdeen. These quarry-owners are chiefly Scotchmen who have come out to St. George from Aberdeen. Several of them sat at a table with me, and I passed to my neighbour a cablegram that I was putting on the wire for Glasgow, summarising the petition for an increased duty on granite from Aberdeen. "They'll think we're darned mean," was his comment as he returned it to me; from which it may be inferred that tariff beneficiaries themselves are conscious at times that there is no good moral defence for leaning on the politicians for their private gain.

No circumlocution was used by many of the tariff beneficiaries who assailed the British preference before the Tariff Commission. "They spoke of London and Liverpool as "foreign," and of Englishmen who came to Canada in search of orders as "foreigners." This use of the word "foreign," as applied to English and Scotch imports, was particularly noticeable in the petition presented at Three Rivers for higher duties on cast-iron pipe from Glasgow. "For every ton of pipe made at Three Rivers in 1904," read one of the paragraphs, "there was expended in Canada a sum of 27 or 28 dollars. This is made up of wages paid to workmen, and of payments to other Canadian manufacturers for pig-iron and other materials required in the production of cast- 
iron pipe. On the other hand, if cast-iron pipe is imported into Canada, it simply means that the only return received by Canada is the duty of five-and-one-third dollars, and one dollar a ton as commission to Canadian agents. About twenty-five dollars is thus sent out of the Dominion to the benefit of the foreign manufacturers."

At the final session of the Commission at Ottawa the Manufacturers' Association defined its attitude towards the preference. It assured the Commission that the desire of the Association was that everything that could reasonably be manufactured in Canada should be made in Canada, and that Canadians should buy their surplus requirements, "so far as is reasonable, from British sources." "We desire," continued this memorial of February 8, 1906, "reasonable competition with the industries of Great Britain and other portions of the Empire; that is, we desire a tariff against these countries which will equalise for the Canadian manufacturer the disadvantages under which he works in the higher cost of labour, capital, and machinery, a tariff which will enable him at least to compete on equal terms in his home market with the manufacturers of Great Britain. We favour the offer of a substantial preference to the other portions of the Empire, but we are strongly opposed to any policy which will prevent or limit the development of our own resources." I

${ }^{3}$ Memorial of the Canadian Manufacturers' Association, p. 11. 
Few of the pleas for a curtailment of the British preference were wholly disregarded by the Government; and in the discussion in committee on the tariff the attitude of the Conservative Opposition towards the preference was clearly defined. Mr. David Henderson, an Ontario Conservative, in the discussion on the wool-schedule, pointed to the large importations of woollens, mostly from England and Scotland, and insisted that the woollenmills of Canada should be better protected from this competition. "I hold," he declared, " that we have just as good a right to use the tariff to defend the country against the invasion of foreign goods as we have to call out the militia to defend it against the invasion of an armed force; and I repeat that if there is an industry in Canada that is entitled to the protection of the tariff, it is the woollen industry."

Mr. Henderson is a back-bench member of the Opposition. Much more significant of the Conservative attitude was the speech made in the same discussion by Mr. Foster, who as Minister of Finance was responsible for the National Policy tariff of 1894, and who since the Conservatives have been in opposition has acted as lieutenant to Mr. R. L. Borden, the Conservative leader. Said Mr. Foster, in this discussion of January 31, 1907 :-

We believe in our country and in its possibilities. We would have just as large a labouring class in the

1 House of Commons Debates, January 31, 1907. 


\section{PROTECTION IN CANADA сн.}

manufacturing industries, including those of textiles, as other great countries with equal population. We would like to have these processes of manufacture carried on among us. Take, for instance, cotton goods, which we discussed this afternoon. One gentleman rises here and says that for the finer goods we have to go to France or Britain. Do we propose to remain always in that condition - that for all the finer classes of manufacture we must pay toll and tribute to other countries? Or shall we, looking to the future and to our proper development, seek to establish these diversified arts and manufactures in our own country? But how will you attain that if you are going to stop at the half-way house, or even before you reach the halfway house, instead of pressing forward to the policy that will bring about the desired state of affairs? It seems to me that the people and the Government should decide what they intend shall be the result which this country shall seek to attain. Shall we go in the direction of diversifying the manufactures of our country and produce the raw material that should naturally be grown here for staples for those manufactures? And, if so, shall we be courageous enough to do what is absolutely necessary in order to bring about that development? Or shall we labour on halting half-way toward the accomplishment of what we should all like to see, but what may, in the meantime, cost us something. To my mind it seems a plain, business proposition : Do we want to protect and consequently have development and wage-paying, and wage-earning and wage-distribution here? Then, if we do, let us provide the means adequate to bring about that state of affairs. If not, let us not make the attempt in a way that will inevitably mean failure. If we are to pay a ligh price, let us make sure that we attain an adequate result. ${ }^{1}$

${ }^{1}$ House of Commons Debates, January 31, 1907. 
The farmers made no appearances before the Tariff Commission of 1896-7. Only manufacturers and importers interested themselves in the sessions of that Commission. The farmers then felt that their interests and the interests of consumers generally were safe in the hands of the Liberals; for they recalled the Ottawa programme, and they were confident that Sir Wilfrid Laurier and Sir Richard Cartwright would implement their oft-repeated pledges of a tariff for revenue only. At the revision of 1905-6 the farmers availed themselves to the full of the opportunities of the public sessions of the Tariff Commission. They were the only consumers who did so. They were the only consumers who were organised; and when the Commission was in Quebec, Ontario, Manitoba, and Prince Edward Island, there was scarcely a town on the Commissioners' schedule at which members of the Dominion Grange, the Ontario Farmers' Association, and the Manitoba Grain-Growers' Association did not appear to protest against any increases in the tariff, and with equal vigour against the continuation and extension of the system of bounties to the iron and steel companies and to other industrial undertakings.

Occasionally, as was the case in Hamilton and in Valleyfield, a farmer with a milk round, or engaged in market gardening, appeared in support of the protective tariff. Such farmers, however, were exceptions ; for 


\section{PROTECTION IN CANADA сн.}

nine out of ten of the farmers who appeared before the Commission were emphatic in their condemnation of protection; and many of them were outspoken in their regret over the betrayal of 1897 . The Liberal cabinet ministers who were of the Commission then learned how deeply Sir Richard Cartwright's speeches in and out of Parliament between 1874 and 1896 had sunk into the minds of the farming population, and how keen was the disappointment of the farmers of Ontario that the election of a Liberal Government in $\mathbf{1 8 9 6}$ had resulted only in a continuation and extension of the National Policy. Again and again, when the Commission was in Quebec and Ontario, its members were assured that the farmers still believed in the policy which the Liberals had advocated when in Opposition $;^{1}$ that the farmers still advocated a tariff for revenue only and a reciprocity treaty with the United States.

The plan of campaign adopted by the Farmers' Association was well organised, and to some extent it was effective; for it was the farmers' opposition that killed the maximum and minimum tariff scheme as enunciated by the Minister of Finance in 1904. Their attitude towards protection also brought about some decreases in the duties on farm implements, - the only noteworthy decreases that

1 Cf. Brantford letter, News, Toronto: "Farmers recall Liberal Promises; Opposition Pledges as to Tariff Reform are Remembered."-November 28, 1905. 
were made at the revision of 1906-7. This opposition was effective because it was well organised. In the Sun of Toronto, farmers of Ontario have a newspaper whose educational influence is far extending. It is the only newspaper in Ontario of wide circulation that to-day supports the case of the farmers against the protected manufacturers, and the progressive protectionism of the Liberal Government; for all the Liberal newspapers of Toronto, Hamilton, and Ottawa, that between 1879 and 1897 were with the farmers in their opposition to protection and bounties, went over to the National Policy when the Liberal Government adopted it in 1897.

Much of the effectiveness of the farmers' opposition at the tariff revision in 1905-6 was also due to the fact that they are permanently organised in the Dominion Grange, the Farmers' Association of Ontario, and the Manitoba Grain-Growers' Association. It was the plan of campaign that individual farmers should appear before the Commission whenever it was in their neighbourhood, and that a joint memorial of these three farmers' organisations should be submitted later. This plan was systematically followed. Wherever the Commission went in Manitoba, Ontario, Quebec, and Prince Edward Island, the farmers recalled the old attitude of the Liberals towards protection, and made it emphatically clear that, no matter what change might have come over the leaders of the 
CH.

Liberal party, the farmers still stood where they did between 1879 and 1896. The joint memorial was submitted on December 18 , 1906, three weeks after the introduction of the new tariff. ${ }^{1}$ It read :-

The farmers of Canada have become genuinely alarmed by the aggressive campaign carried on by the Manufacturers' Association during the past few years, with a view of having the tariff made more protective than it is now. When protection was first asked for, we were assured that what was then requested would be required but a short time in order to allow our manufacturing industries to secure a fair footing. The request made was granted by the electors; and the rate of taxation levied on dutiable goods averaging twenty-one and a half per cent in 1878, was increased to an average of twenty-six per cent by 1880 . To-day we have an average tariff on dutiable goods about one and a half per cent higher than it was when the protective tariff became effective. And yet with the infants of that period grown to the mammoth concerns of the twentieth century, we find the cry is still for more. The more there is given and the less the requirement for giving, the greater are the demands made. If a halt is not at once called we shall find conditions in this country similar to those prevailing in parts of Europe, with a small class of wealthy barons at the top and serfs at the bottom-manufacturers being the barons and farmers the serfs.

The protection accorded by the tariff enables manufacturers of certain classes of agricultural implements to charge Canadian consumers twenty-five per cent more than the value of the articles manufactured. The same protective tariff permits an overcharge of thirty per cent to nearly fifty per cent on woollen goods, and fifty per cent on the cheaper lines of farm carriages.

1 Ottawa Correspondence, Globe, December 19, 1906. 
The average rate of taxation on dutiable goods in 1904 was twenty-seven and a half per cent, and to that extent, speaking broadly, Canadian manufacturers were enabled to overcharge Canadian consumers on purchases made by those consumers. Farmers do not, and cannot, secure any compensation in return for all this by any tariff that can be devised. We have to-day a surplus of one hundred and twenty million dollars of farm produce for export; that surplus is constantly increasing; and so long as these conditions continue, the foreign price must control the home price of farm products. While a protective tariff can and does limit our purchasing power, it cannot and does not enhance the price of articles we have to sell.

We therefore ask, in the coming revision of the tariff, that the protective principle be wholly eliminated; that the principle of tariff for revenue only-and that revenue based on an honest and economical expenditure of the public funds-be adopted; and as proof of our sincerity we will, if this position is adopted by the Government, gladly assent to the entire abolition of the whole list of duties on agricultural imports. ${ }^{1}$

As soon as it was realised that by the revision of 1906 the iron and steel bounties were to be extended until 1912, the Dominion Grange presented petitions to Parliament condemning the bounty system, and urging that the "iron tubs, as well as other tubs," should be permitted to stand on their own bottoms. ${ }^{2}$ But in its opposition to the bounty systeman opposition persisted in until the Bounties Act was at its final stage in the House of

1 The memorial was signed by J. G. Lethbridge, Master, Dominion Grange ; James II'Ewing, President, Ontario Farmers' Association; D. W. M'Cuaig, President, and R. Mackenzie, Sec.-Treasurer, Manitoba Grain-Growers' Association.

2 Globe, February 21, 1907. 


\section{Commons-the Dominion Grange achieved no success. $^{1}$}

1 The Sun estimated that this extension of the bounty system to 1912 would cost the Dominion $\$ 18,000,000-\$ 3$ for each man, woman, and child in the Dominion. "Let us see," it remarked in an editorial article, on March 13,1907, "what a few representative Ontario constituencies will be required to pay as their share of this total of eighteen million dollars. Peel, with a population of less than 22,000 , will be called on for $\$ 66,000$; South Pertl, with 20,000 people, for $\$ 60,000$; South Ontario, with 22,000 , for $\$ 66,000$; Muskota, with 21,000 , for $\$ 63,000$; Durham, with 27,000 , for $\$ 81,000$; West Kent, with 32,000 , for $\$ 96,000$; East Simcoe, with 30,000 , for $\$ 90,000$; South Wellington, with 30,000 , for $\$ 90,000$; and Welland, with a population of 32,000 , for $\$ 96,000$. Here are nine Ontario ridings which will be called upon to pay from sixty to ninety-six thousand dollars each in four years in bonuses to iron industries. It is rather more than a coincidence that the chief beneficiary of this bounty system is located in the province of which Mr. Fielding is political leaderthe province which elected a solid ministerial delegation in the last Dominion election. The Dominion Iron and Stecl Company at Sydney, N.S., has received $\$ 3,000,000$ in the last four years [the actual sum was $\$ 3,466,519-$ House of Commons Debates, February $14,1907]$, and will, according to the estimates of its own officers, obtain at least $\$ 7,000,000$ in the next four, if the new scale of bounties is approved. That will mean a total in gifts to this one corporation, located in Nova Scotia, of ten million dollars-over twenty dollars a head for the entire population of that province. It is no wonder, when he is in a position to distribute such magnificent largesse, that Mr. Fielding can bring with him to the House of Commons a solid following from his own province; and that he is, because of his strength at home, accepted as the political heir of Sir Wilfrid Laurier. But what do the people of Ontario, who pay forty per cent of the customs taxation out of which the iron bounties are taken, think of the price they are asked to pay for the position Mr. Fielding now lolds, and is so anxious to retaill ?" 


\section{CHAPTER XIV}

\section{POLITICS AND THE TARIFF}

TuE tariff has too long been used for the basest party motives. Too long has it been the dreaded rod of correction held up warningly to whip doubtful waverers into line, or to bribe and win over actual opponents. . . Henceforth the tariff must be framed with a view to absolutely securing and reserving Canada for Canadians.-JOHN RANSFORD of Canadian Manufacturers' Association-Toronto News, September 27, 1907.

IT is a source of satisfaction to manufacturers to know that the party in power, which was originally a low tariff or free trade party, has, under the responsibility of office, seen how impossible such a policy is if Canada is to continue her progress as an industrial nation. At the same time we feel that the Government has either not realised how essential it is in the case of many industries-which are even now in these most prosperous times feeling keenly the effects of foreign competition-that they should receive more adequate protection, or if they have realised it they bave not had the courage to put such a policy into effect.-Report of Tariff Committee to Canadian Manufacturers' Association, September 24, 1907.

In view of the fact that the farmers, who constitute so large a proportion of the voting population of the Dominion, are so strongly 


\section{PROTECTION IN CANADA сн.}

and so generally opposed to the National Policy, it may be asked how it is that Liberal governments have been twice returned to power ${ }^{1}$ since the betrayal of 1897 . Two important factors in Canadian politics help to answer this question. The most important of these is, that since 1896 there has been no opposition in the House of Commons from which the farmers could expect any assistance in continuing their old campaign against high duties and bounties for manufacturers. From 1879 to 1896 the Liberals were a most effective Opposition, and through these years there existed a force at Ottawa to which the opponents of protection in the constituencies could rally. Since 1897 the privileged order of manufacturers has held captive both political parties, and the farmers have had no representation in Parliament on this question. Except at elections, and on such occasions as the tour of the Tariff Commission, they are inarticulate, and even at elections they have no real opportunity of voting according to their interests and convictions. To vote for Conservative candidates would avail them nothing, for the Conservatives are even more protectionist than the Liberals; while as regards Liberal candidates, no independence can be expected from them, because unless they pledge themselves to support the Government and act with the Liberal caucus, they can expect no Government help in their election.

1 General elections of 1900 and 1904. 
A political party once entrenched in power at Ottawa has many means of keeping itself in power such as have long ceased to be available for a Government at Westminster. Tariff and bounty beneficiaries, railway promoters, and subsidy hunting corporations, men with railways to sell to the Government, Government contractors, and wealthy men who have been, or who are, seeking to be appointed to the Senate, all contribute to replenish the war chest when a general election is pending. ${ }^{1}$ Civil servants in many constituencies become zealous election agents in support of the men who have secured their appointment. Since 1905 there has been a resolution on the Standing Orders of the House of Commons ${ }^{2}$ mildly forbidding such partisan activity by employees of the Dominion Government; but it has never had any terrors for civil servants whose election activities were in the interest of Government candidates. ${ }^{3}$ These civil servants, almost invariably, it should be stated, men on the outdoor staffs of the state departments, can always depend on the Government coming to their aid if their zeal

${ }^{1}$ Cf. Election Funds, News, Toronto, August 20, 1906; "A Cure for Corruption," Star, Montreal, January 9, 1907. "It is to be hoped," said the Star, in commenting on a meeting to be held at Victoria University, Toronto, on January 10, 1907, to consider remedies for the prevalence of corruption in Canadian politics, "that they will give us no such academic cure-all as compulsory voting, but will strive to get at the sources of corruption, which lie not very far from the people who are willing to subscribe to campaign funds with the hope of getting legislative favours."

2 July 17, 1905.

3 Cf. Government Officials and Elections, House of Commons Debates, April 15, 1907. 
should outrun discretion and their excess of partisanship be challenged in Parliament.

Aid from these men counts for much in scattered constituencies; and in the smaller towns and cities there is a species of Government bribery that has long since disappeared from English electioneering, except perhaps in dockyard constituencies. This Government favour is distributed through the great spending departments - those charged with providing post office and customs-house buildings; stations on the Intercolonial Railway; the dredging of rivers and harbours, and the building of bridges, docks, and breakwaters. Such public works involve large expenditures in a constituency. They often enhance the value of property in their neighbourhood, and they pander to local prideall of which tells enormously in favour of a member who supports the Government when he seeks re-election. Government members also have the distribution of civil service patronage in the constituencies, and much influence in the awarding of local contracts. The longer a Government is in power the greater the number of its interested friends.

In addition to these advantages the Government at Ottawa exercises much control over the press which supports it. "Strong evidences have unhappily been produced," wrote Mr. Goldwin Smith, in 1891, while the Conservatives were still in power, "to show that by Government advertising and printing 
contracts this system of corruption has been extended to the press. What influences are behind the press has become for all commonwealths alike one of the most serious questions of the day."

There has been no change for the better in this respect since 1891. The only difference is that since 1896 practically all the money that the Government spends on advertising, and on such printing as is done by houses associated with a newspaper, has gone to Liberal instead of Conservative newspapers. Tens of thousands of dollars may be spent in advertising and printing in one city, but, as the Auditor-General's reports show, not one per cent of the money goes to Opposition newspapers. Advertising is not distributed on a business basis. It goes to the newspapers which support the Government. This patronage is regarded as their due by the newspapers in return for the support which they give to the Government.

One change there has been since Mr. Goldwin Smith wrote in 1891 which is distinctly for the worse. Newspapers in Toronto, Hamilton, St. John, and Halifax, which were with the Liberals when they were in Opposition, are now controlled by promoters or captains of industry who are directly interested in the iron and steel bounties or the high duty on coal maintained in the interest of two or three large coal companies in Nova Scotia and

I Goldwin Smith, Canada and the Canadian Question, p. 227. 


\section{PROTECTION IN CANADA сн.}

British Columbia. The result is that these Liberal newspapers are essentially organs of the Government. Any tariff policy that the Government adopts is secure of their commendation; and as the Conservative newspapers also advocate high tariffs, the farmers have no support in the daily press in any active campaign they undertake against protection.

The cement of party ties is, moreover, infinitely more enduring in Canada than in recent years it has been in England, or than it has been in the United States since the Mugwump movement of 1884, to which Mr. Cleveland owed his election as President. Party conditions in Canada are such that an independent movement has small chance of success ; and only an upheaval, such as that of 1896, can dislodge a Government at Ottawa that has had ten years in which to entrench itself.

Few words are necessary to deal with the last aspect of the proceedings of the Tariff Commission of 1905-6-the attitude of the people of Canada towards Mr. Chamberlain's scheme of 1903 for a British preference for Canadian and other colonial produce. No better plan than the Tariff Commission could have been devised for ascertaining public opinion in the Dominion on this scheme. I was in attendance at thirty-one of the public sessions of the Commission, yet during the whole of this time I heard only three Canadians 
commend Mr. Chamberlain's policy. ${ }^{1}$ It was opposed by the federation of trade unions at Toronto; and the usual attitude of the farmers towards Mr. Chamberlain's scheme was that they were content with existing trade relations with Great Britain, and that they had no desire that the food of the people of the Old Country should be taxed for the advantage of the farmers and stock-raisers of Canada. At Three Rivers, Quebec, ${ }^{2}$ the representatives of a wood-pulp paper-making company, capitalised at four million dollarsa representative of the only industry in Canada that has had its protection in the tariff curtailed under the anti-trust clause of the tariff of 1897 -appeared before the Commission to urge an export duty on pulp-wood going into the United States, in order to reduce the competition that Canadian paper-mills meet from American manufacturers in England, South Africa, and Australia. After the petitioner had presented his case, I asked him, "How would Mr. Chamberlain's scheme affect your industry?" "Make us all rich," was his laconic but significant reply.

There have now been four general revisions of the tariff since the National Policy was adopted in 1879 -two by Conservative ${ }^{3}$ and two by Liberal administrations. ${ }^{4}$ They have

1 Montreal, November 9; Hamilton, November 24; St. Hyacinthe, December 30, 1905.

2 December 27, 1905.

31884 and 1894.

- 1897 and 1906. 


\section{PROTECTION IN CANADA сн.}

all been in harmony with the MacdonaldTilley policy of reducing imports-all in the interest of the privileged order of Canadian manufacturers. But at none of these four revisions was the triumph of the privileged order more complete or more signal than at the revision of 1906 . The privileged order secured an outstanding triumph in 1897, when the Liberal Government adopted the National Policy and continued the bounty system. In 1897, however, the tariff was not revised at the instance of the manufacturers. It was revised because the Liberals were committed by their pledges in Opposition to immediate action on the tariff, although to action in a diametrically opposite direction to that which they deemed it expedient to take. In 1905-6 the tariff was revised solely at the demand of the Canadian Manufacturers' Association ; and, as was admitted in the speech from the throne at the end of the session of 1907 , no other interest than that of the manufacturers was considered by the Government when the revision was in progress. All that was then claimed for the work of the Tariff Commission, and of Parliament on the tariff-work that had occupied ministers and Parliament from September 1905 to April 1907-was that it was believed that the revision would " meet with the general approval of the trade, removing as it does many inequalities heretofore existing." 1

House of Commons Debates, April 27, 1907. 
The Government was as candid in this admission as the Minister of Finance was outspokenly protectionist in advocating higher duties in the tariff and the continuation of the bounty system. ${ }^{1}$ No claim was made in the speech from the throne that any care had been given to the interest of the general consumers. Had such a claim been made, it could not have been substantiated; for almost the only reductions were those in the duties on agricultural implements, made in the interest of the farmers as producers, and a reduction from six and two-thirds to five per cent on books and printed music under the British preference. Scores of changes were made in the tariff-in the general list and in the British preference list,--but they were all aimed at reducing imports; and all of them were in compliance with requests from the privileged order when the Tariff Commission was on its round.

These concessions to manufacturers, which ranged from one and a third to seven and a half per cent, constituted a signal triumph for the privileged order, owing to the circumstances in which they were granted. They were conceded by a Government, every prominent member of which had for years denounced protection in all its phases in the most uncompromising language. Moreover,

${ }^{1}$ House of Commons Debates, November 29, 1906, and subsequent days, when the House was in committee on tariff and bounty legislation. 


\section{PROTECTION IN CANADA сн.}

most of the concessions were made to interests which had been compelled to abandon the out-worn infant industries plea; interests concerning which there was obvious and overwhelming proof that they were rompingly prosperous under the duties as they stood after the amendments of 1904; interests which it was notorious had constituted themselves into trusts and combinations, and had put an end to competition within the tariff wall; and, finally, many of these concessions, so easily and so accommodatingly granted by the Government, involved curtailments of the preference, and a complete departure from the system established in 1897 of uniform reductions in favour of imports from Great Britain.

These concessions, coupled with a change made later in the postal regulations, intended to exclude as far as possible American advertising from Canada-a change in line with the policy of reducing imports, much pressed by manufacturers when the Tariff Commission was at Toronto, Windsor, and Quebec - constitute the most remarkable triumph achieved by the privileged order since the tariff of 1879 was enacted.

For England, at this juncture, the most significant of these concessions to the privileged order of Canadian manufacturers was the curtailment of the preference. I have indicated the nature of the pleas on which some of these changes were made by the Government. Taken as a whole, these many cur- 
tailments of 1906-on jewelry, on silverware, on low-grade blankets, on printed cottons, on cast-iron pipe, on tombstones, and on many other items in the tariff - have one general significance for political parties and political leaders in England. They show that it is hopeless for British manufacturers to expect any further tariff concessions from Canada. They also afford proof that since 1904 the tendency in tariff legislation has been consistently in the contrary direction. My experience with the 'Tariff Commission, and with tariff-making at Ottawa and at Washington, has convinced me that it can never be practicable to interlace a protectionist system in England with a protectionist system in Canada or in any other British colony in which manufacturers are protected. Should any such scheme be tried, I am convinced that it would be found as impracticable as it would be to deprive Canada and the United States of Niagara Falls, and set them up on the Thames at Richmond.

Were such a scheme of tariffs attempted it would break down in Canada at the outset for exactly the same reason that since 1904 there have been so many curtailments of the preference established in 1897. If it were proposed that there should be such and such reductions in duties on manufactured goods from England in return for preferences on Canadian products, the question asked at Ottawa would not be, how such changes 
would benefit the whole people of the Dominion or increase trade with Great Britain. Confronted with such a proposition, the people of Canada, as a whole, would be as little considered as they admittedly were when the tariff was revised in 1906. The question for ministers at Ottawa would be, how such a reduction would affect the hold of this minister over this province; how it would affect the next election in that constituency; what campaign subscriptions would be endangered; or what daily newspaper, controlled by a millionaire captain of industry, might be thrown into opposition.

Tariff politics, in a word, are obviously and essentially the most unsocial and most provincial of petty politics. They set every man's hand against his neighbour; class against class; farmers and importers against manufacturers; coal producers against coal consumers; province against province; and colonial manufacturers against manufacturers in the Mother-land. They are, moreover, utterly antagonistic to any neighbourly policy among nations, or to any large conception of Empire. 


\section{INDEX}

Abbott, Premier, 177

A berdeen, Lord, 445 and Delane, 45

Adams, U.S. Minister, 157

Ad valorem duties, adopted in tariff, 136 ; prejudicial to U.S., 164 ; Galt's statement concerning, 252 ; extension of, in 1859 , 253

Advertising, American trade, 367; distribution of, by Government, 458

Algoma Steel Company, 399

Allan, Sir Hugh, and protection, 205 ; and C.P.R. scandal, 276

American factories in Canada, 410 Annexation to United States, Buchanan predicts, 65 ; movement for, 67,69 ; no desire for, 69 ; Elgin on, 84 ; fear of, by South, 115

Anti-trust laws, 347,350

Association for Promotion of Canadian Industry, 65, 144, 160,438 ; organisation of, 218 ; proposes tariff schedules, 226 ; its success in 1858,229 ; meeting of, in 1866, 261

Baldwin, Mr., 77

Bates, Mr. J. C., article on reciprocity by, 162

Belle Isle, ore deposits on, 26

Betrayal of Canadian Liberalism, 362

Blaine, J. G., Secretary of State, 177

Blair, Mr. A. G., 399, 400, 401
Blake, Mr. Edward, Leader of Liberal party, 21, 77, 175, 356

Blast furnace, only one in Canada, in 1879,323

Bonding system, 167

Bonuses to industries, 289, 410

Booth, James, 255

Bopp, Mr., German: ConsulGeneral, 416

Bounties to industries, 2 ; cost of, to Canadians, 11 ; continued by Liberals, 33

Bounties to iron and steel industry, 16; since 1896, 26 ; Laurier Government and, 27 ; granted in 1883,33 ; first payment of, 170 : enacted in 1883, 324; Liberal Govern. ments and, 366, 399; amounts of, 401 ; rates of, 404 ; review of, 404 ; on imported ores, 405 ; Sun estimates cost of, 454

Bounty legislation, by Liberals, 24

Bowell, Sir Mackenzie, 177, 219, 354

Brantford, 431

Bribery, by party in power, 457 , 458

Bright, John, 358, 360

British Columbia and Ottawa Convention, n. 37

British failure to meet Canadian needs, 365

British manufacturers, and removal to Canada, 201, 235 ; 
and advantages in Canadian tariff, 322

British Possessions Act, 188

British protests against Canada's fiscal policy, 191, 243 ; last of, 360

British shipping, hurt by tariff of 1870,269

Brodeur, Mr. L. P., Minister of Inland Revenue, 431; and figures of imports, 442

Brown, George, $81,165,170$

Buchanan, Isaac, 201, 261, 438 ; father of National Policy, 39 ; and Association for Promotion of Canadian Industry, 43, 218; predicts loss of colonies, 44 ; complains against British Government, 64; and ElginMarcy Treaty, 130; proposes American Zollverein, 131, 173; and home market, 212 ; and "Britain the Country versus Britain the Empire," 227 ; and new campaign for protection, 235

Bulwer, Sir Henry, and reciprocity, 100, 107

Campaign contributions from protected interests, 333,355

Canada, a cheap country, 6 ; and the Corn Laws, 49 ; and fiscal freedom, 57, 61, 62 ; a high tariff country, 68 ; as a plantation, 200

"Canada for Canadians," 294, 397 ; whole trade to be reserved, 440

Canadian Manufacturers' Association, 28, 200, 219, 422 ; organisation of, 220 ; and National Policy, 266 ; and skilled labour, 338 ; and immigration, 339 ; and tariff revision, 367 ; and British preference on woollens, 397 ; and "Made in Canada" movement, 423 ; and tariff revision agitation, 424

Canadian Pacific Railway scandal,
266, 276 ; Royal Commission on, 278

"Canadian Trade Index," 351

Canals, Canadian, and reciprocity, $95,99,120,128$; discriminating tolls on, 142

Cape Breton, and iron industry, 14

Cardwell, Colonial Secretary, 357

Carnarvon, Earl of, Colonial Secretary, 165

Cartwright, Sir Richard, his article in North American Review, 3 ; attacks protection, $12,19,32,74,242$; and pro. tection to farmers, 18 ; the Cobden of Canada, 19; and the premiership, 20 ; and Liberal leadership, 22; Minister of Trade and Commerce, 23 ; loses prominence, 24 ; ceases to oppose protection, 25 ; and cost of protection, 30 ; and reciprocity, 145 ; and Joint High Commission, 182 ; and sugar industry, 240; Minister of Finance, 263 ; drafts tariff in 1876,283 ; answers attacks, 284 ; his Budget in 1878,295 ; defends free trade, 296 ; adheres to free trade, 308 ; criti. cises Tilley's tariff policy, 325; characterisation of, 326 ; his speech of 1879,328 ; his exposure of political and social dangers, 329 ; his predictions in 1879,329 ; and duty on rice, 354 ; speech of, in 1890 , 368 ; his speech at Ottawa Convention, 375 ; and change of Liberal policy, 382,386

Cathcart, Earl of, 46, 48 ; announces British changes of 1846, 58

Cayley, Inspector-General, 58, 188; waited on by protectionists, 226; and tariff of 1858,234

Cayley Tariff of $1858,43,134$, 206,228

Chamberlain, Mr., 394, 398 ; his 
scheme for colonial preference, 360 ; impracticability of scheme of, 465

Chandler, Zack, 155

Charlottetown, P.E.I., 433

Charlton, Mr. John, "Trade Relations with the States," 122 , 166 ; and immigration, 336 ; and cost of protection, 341

Chatham, 315, 411 ; Tariff Commission at, 9,431

Cheap foreign labour cry, 280

Chronicle of Halifax, 369

Cigar-store Iudians, 185

Civil service, and political partisanship, 457

Civil Var, and trade with Canada, 124 ; and irritation against England, 129

Clergue, MIr. Francis, 399 ; and contract for rails, 401,405

Clergy Reserves, 35

Cleveland, Grover, and U.S. tariffs, 35

Clocks, duty on, in 1879,321 , 322

Coal, and tariff duty, 16, 204, $261,263,266,267$; imported from U.S., 268 ; British trade in, 270 ; duty increased in 1881,271 ; duty on, in 1897 , 272 ; plea for re-enactment of duty on, 290 ; duty reimposed in 1879,320 ; combine in industry, 345 ; duty on anthracite repealed, 353

Coal interests in 1897, 382

Coffins, demand for higher duty on, 439

Collamer of Vermont, 116, 153

Collingwood, Ont., 168

Colonial Office, and controversy with Galt, 242, 259 ; and protection in 1859,256 ; no protests from, 357

Combines, in oil-refining, in 1878, 343 ; in cotton, 344 ; aggressiveness of, in 1888, 344; Act for suppression of, in 1889,346; Act of 1897,347 ; uselessness of Acts, 348
Commercialised patriotism, 323

Commissioners, Canadian, in 1891, 177

Confederation, 187 ; protection at, 202 ; and protection, 262

Conservative Governments, in power until 1896, 353

Conservatives, in 1896, 20 ; fully adopt protection, 287 ; attitude of, to British preference, 300 ; support policy of Liberals, 367 ; dished by Liberals, 430

Consumers, at mercy of manufacturers, 9 ; not regarded by Government, 11, 463 ; coralled for producers, 320 ; regard for, by Liberals, 420

Contract Labour Laws, 339

Corn Laws, repeal of, oppositiou to, in Canada, 55; and trade advautages for Canada, 97, 107, 208

"Corruption, A Cure for," 42

Corruption, political, 333 ; resulting from protection, 334

Cotton manufacture, beginnings of, 168,169 ; in 1879,320 ; combine in, 344 ; and Liberal Government, 382

Cotton schedules, in tariff of 1879,320 ; in tariff of 1897 , 388

Cottons, demand for higher duty on, 439

Crown lands, lumber cut on, 366

Dana, Charles A., 70

Davies, Sir L., and reciprocity, 180 ; and British preference, 392

Delane, and Aberdeen, 45

Denton, 444

Derby, Earl of, Colonial Secretary, 122

Detroit Convention, 1865, $n .162$

Differential duties, in 1846,53 ; reimposition proposed, 98,105

Dingley tariff, $1,30,392,425$, 428,430

Dix, Senator, 89, 90, 92, 97, 138, 147 
Dominion Grange, 17, 432, 451, 453

Dominion Iron and Steel Company, 32, 402, 438 ; and bounties on imported ores, 406

Dominion Textile Company, 438

Dorion, Mr., M.P., 231

Douglas of Illinois, 100

Drummondsville, Quebec, 405

Dufferin, Lord, Governor-General, 165

Dumping, first complaint of, 168, 232 ; first debate on, 230 ; not from Britain, 408

Dumping Act, 28, 366 ; terms of, 407 ; protests from Liverpool Chamber of Commerce, 409 ; protests from Canadian manufacturers, 409

Eastern Townships, 293

Edwards, Mr. W. C., 400

Election petition against Mr. Fielding, 313

Elgin, Earl of, Governor-General, 83 ; and reciprocity, 84, 91; and fisheries question, 104 ; and British protests, 194

Elgin-Marcy Treaty, 45, 79 ; signing of, 118; terms of, 119; denunciation of, 129 ; lack of permanence of, 130 ; assailed in U.S., 133 ; reports on, 134 ; effort for abrogation of, 145, 150 ; arguments against, 152 ; abrogated, 157

Ellice, Bear, 293

Ellis, Mr. J. F., 426, 442 : and British preference on jewelry, 443

\section{Fall River, 440}

Family Compact, 35, 384

Farmers, and tariff protection, 16, 17 ; and reciprocity, 161, 174; protection for, in 1870,270 ; in favour of protection, 289 ; and National Policy, 309 ; and Tariff Commission of 1896, 383,431 ; and tariff wars, 418 , 441 ; their opposition to manu- facturers, 441; and Tariff Commission of $1905-6,449$; and free trade, 450 ; campaign against tariff increases, 450 ; organisation of, 451 ; joint memorial of, 452 ; petition against bounties, 453 ; their support of Liberal Governments, 456

Favoured-nation treaties, 393

Fielding, Mr. H. S., 18, 363; and tariff of 1906,6 ; defends tariff, 10 ; becomes Minister of Finance, 23, 263 ; his conversion in $1897,25,206$; and protected interests in 1906, 36; and Ottawa Convention, 178 ; converts Nova Scotia, 204; and coal duty, 272; election petition against, 312 ; at $0 t-$ tawa Convention, 370,372 , 375 ; introduces tariff, 1897 , 386 ; and British preference, 392 ; and Dumping Act, 407 ; and German surtax, 415 ; promises tariff revision, 428 ; chairman of Tariff Commission, 431

Fillmore, President, 96

Finance, Minister of, Mr. H. S. Fielding, 23 ; Galt, first, 237

Fiscal freedom for Canada, 189 ; and Colonial Office, 242 ; vindicated by Galt, 250; conceded by Hicks-Beach, 358

Fiscal policy, debated at Ottawa Convention, 371

Fish, Secretary of State, 166, 170 Fisher, Mr. Sydney A., 18

Fisheries question, 103, 105, 109, $111,118,125$; settled in 1854 , 119

Foreign, applied to British in Canada, 445

Foster, Mr. George E., 19, 175 ; attacks British preference, 393; speech on tariff revision in 1907,448

Free land and immigration, 15

Free list, and National Policy, 205 ; growth of, 217 
Free sites, for factories, 11,410

Free trade, and sacrifice of colonial interests, $63,81,97$, 107 ; league for, 66 ; movement for, 72; no absolute, in Canada, 76 ; under treaty of 1854,120 ; defence of, by Mackenzie, 291

French Canada, and Liberal leadership, 71

Fugitive slave law, 95

Galt, Sir Alexander T., InspectorGeneral, 131 ; responsible for abrogation of treaty of 1854 , 144, 188; first Minister of Finance, 237 ; and protection in 1859,238 ; and sugar industry, 240; his reply to Newcastle, 248; his triumph, 259 ; his prevarication, 260 ; and Manchester Chamber of Commerce, 357

Galt tariff of $1859,134,167$

Gamble, Clark, 198, 206

Gee, Joshua, 208

General Election of 1878, 299, 308,314

George, Mr. W. K., 443

German tariff war, 413

Gesner, "Industrial Resources of Nova Scotia," 203

Gillmor, Mr., 39, 437

Gladstone, Colonial Secretary, 48 ; and Colonial trade, 49,59; and C.P.R. scandal, 278

Glasgow and Canadian tariff, 192, 193; iron pipe from, 444, 445

Globe, 123, 206, 215, 232, 369 ; and free trade movement, 74 ; and reciprocity, 81 ; advocates free trade, 222 ; and tariff of 1858,233 ; announces tariff changes in 1876,283 ; and protection of labour, 340

Gold and Silversmiths'Association of Canada, 443

Grain area in Canada, 213

Granite, duty on, in 1906, 321 ; increase of duty on demanded, 445
Grant, President, 171

Grey Earl, Colonial Secretary, 192

Hale, Senator, 89, 130

Hamilton, and protection, 131, 198,219 ; industries in, 169 ; and election of 1874,278 ; Macdonald speaks at, 310 ; and clock industry, 321 ; and iron and steel industry, 405 ; and bonuses to industries, 412 ; Tariff Commission at, 431

Hamilton Spectator, 232

Harrison, President, 177

Hatch, Israel T., 134

Head, Sir E. W., GovernorGeneral, 242

Henderson, Mr. David, 447

Hendricks, Senator, 156

Herries, Mr., and reciprocity, 85

Hicks-Beach, Sir M., Colonial Secretary, 358

Hincks, Francis, 74; goes over to protection, 78,205 ; and reciprocity, 96 ; threatens retaliation, 98, 107 ; and fisheries question, 110

Hincks-Morin Administration, 74

Home market for Canadians, 212

Howe, Senator, 154

Hyman, Mr., and tanners' trust, 350

Immigration into Canada, 14, 213 ; and protection, 336 ; government cost of, 336 ; restrictions on, 338

Immigration into the U.S., laws regulating, 337

Imperial Federation League, 360

Imports, reducing the volume of, $316,363,367,368,461$

"Industrial Canada," 426

Industries in Canada, beginnings of, 168,191 ; encouragement of, 211; favoured in Tariff Acts, 236

Industry leans on the politician, 3,40

Infant industries, 41,437 ; disappearance of plea of, 438 
Inspector-General becomes Minister of Finance, $n .58$

Intermediate tariff, 432

Iron, duties on, British protests against, 359 ; and Liberal Governments since 1897,382

Iron and steel industry, and protection and bounties, 16, 169 ; beginnings of, 190 ; the tariff favourite, 237 ; protection for, in 1879,323 ; a ereation of the Liberal Government, 404 ; review of, 405 ; and Dumping Act, 406

Jarvis, W. B., 220

Jewelry, duty on, in 1906, 321 ; increase of duty urged, 442

Joint High Commission, 122, 174 ; members of, 182

Jubilee, Colonial Conference, 359

Labour, not protected in Canada, 341

Labour Bureau of Canadian Manufacturers' Association, 339

Larned, his report on Elgin-Marcy Treaty, 123 ; report on trade relations with Canada, 161, $n$. 270

Laurier Government, and protected manufacturers, 10 ; and protection to farmers, 17 ; adopts protection, $27,28,386$; pushes National Policy, 422; farmers' support of, 456

Laurier, Sir Wilfrid, in 1896, 21 ; abandons his old position, 25 ; and protected interests, 36 ; attacks protection, 75 ; on Joint High Commission, 182 ; responsible for protection, 188; first speech on fiscal policy, 285; Minister of Inland Revenue, 285 ; adopts free trade, 309 ; his speeches at Ottawa Convention, 372,378 ; proposes tariff resolutions at Ottawa, 378 ; his speech at Wiunipeg in 1894, 380 ; forms his Administra- tion, 381 ; and change of Liberal Policy, 386; and British preference, 391; and intermediate tariff, 432

Legalised robbery, 355

Liberal Campaign Book of 1896, 380 ; of 1904,410

Liberal Government, policy of, 367 ; and vested interests in 1897, 383; and privileged orders, 385 ; explanation of change of policy of, 385 ; and contracts for rails, 401 ; and German surtax, 416

Liberal party in 1896, 20 ; attitude towards protection of, 75 ; abandons protection, 188; in Opposition, 369 ; supported by farmers, 456

Liberal Platform of 1893,76

Liberalism, disappearance of, 34 ; survival of, 172

Liberals and caucus control, 38

Liberals in Opposition, attack National Policy, 10 ; vigilance of, 40, 456; and reciprocity, 178

Lincoln, President, 149

Logan, Mr. Hance, 397

London, Ont., Tariff Commission at, 9,43 ; and beginnings of protection, 43

Londonderry, N.S., 323, 325 ; and iron industry, 405

Lumber trade, and corn laws, 49 ; and reciprocity, 128

Luton, 444

M'Carthy, Mr. D'Alton, 390

McClelland, 89, 139

MeKinley Tariff, 391

Macdonald, Sir John A., 17, 20, $177,182,186$; commits himself to protection, 171 ; and National Policy, 266, 421 ; his defeat in 1871,275 ; and C.P.R. scandal, 276 ; and farmers, 289 ; and National Policy resolutions, 290, 301 ; urges protection in Eastern Townships, 293 ; his rehabili- 
tation, 294 ; praises National Policy, 309 ; his lack of sincerity in Maritime Provinces, 311 ; his victory in 1878,314 ; and protected manufacturers, 355 ; and Manchester Chamber of Commerce, 360 ; and bonuses to industry, 411

Macdonald Govermment, fiscal policy of, 316

Mackenzie, Alexander, 20, 77 ; and draft treaty of 1874,165 ; and National Policy, 275 ; adheres to free trade, 291; his defeat in 1878,314

Mackenzie Govermment of 187478,279 ; raises tariff duties in 1874, 281 ; and protectionist followers, 282 ; increases duties in 1877,289 ; defence of, in 1878,308 ; defeat of, 308

MacLean, John, 261

"Made in Canada," 27, 366, 397, 423 ; pasters of, 424

Mail of Toronto, 310

Manchester Chamber of Com. merce, addressed by Galt, 239, 260 ; protests from, 357

Manifesto, annexation, 67

Manifesto of Canadian Manufacturers' Association in 1903, 427

Manifesto, Montreal, for free trade, 76

Manitoba Grain-Growers' Association, $18,432,451$

Manitoba, Tariff Commission in, 431

Manufacturers, and specialisation, 9, 258; draw up tariff schedules, 10 ; levy toll on people, 15 ; and change of Government in 1896, 26 ; wait on Minister of Finance, 224 ; and suggestions for tariff schedules, 225 ; and duty on coal, 273 ; hold convention at Toronto, 288 ; invited to fix tariff rates, 310 , 317 ; and tariff revisions, 316 ; their relations with Governments, 354 ; a privileged order, 384,456 ; and tariff of 1897 ,
387 ; and Dumping Act, 409 ; and German surtax, 418 ; promised tariff revision, 430 ; and Tariff Commission of 1905-6, 434 ; egregious demands of, 435 ; their reasons for more protection, 438 ; attacked by farners, 441 ; demand protection against low wages of England, 443 ; tariff revisions, in interests of, 461 , 462

Manufactures, distribution of, 4, $12,14,202$; absence of competition in, 7 ; inferiority to American, 9 ; in 1858 and in 1901, 39 ; and Elgin-Marcy Treaty, 131 ; and draft treaty of 1874,171

Mannfacturing, an alternative to farming, 280, 302

Maritime Provinces, and reciprocity, 180 ; and free trade, 202 ; tariff duties in, 204, 262 ; and Confederation, 262; and National Policy, 311

Marmora iron works, 190

Marshall, Mr., M.P., 390

Mathewson, Mr., and tariff duties on soap, 230

Maximum and minimum tariff, 428 ; abandonment of, 432

Memorial from Sheffield, 244

Merritt, 82, 91, 107

Mills, David, 241

Minister of Finance, the first, $n$. 58,237

Montreal, carrying trade of, 47 ; and annexation, 69 ; dominance of interests of, 143 ; longshoremen's strike at, 340 ; and cotton combine, 344, 351; and rubber combine, 350; and Liberal Govermment in 1897 , 383

Mugwumps, 279, 460

Mnnicipalities, largesse to industries by, 11, 410

National Policy, and change of Government in 1896, 26 ; 


\section{PROTECTION IN CANADA}

Buchaman and, 39,45 ; commencement of movement for, 67,68 ; first enactment of, 140 ; incompatible with reciprocity, 144 ; beginnings of, 190 ; and example of U.S., 210 ; two epochs of, 265 ; resolutions in favour of, 288, 290,301 ; as diversifying employment, 302 ; Macdonald's definition of, 303 ; and interprovincial trade, 305 ; Laurier ridicules, 309 ; enactment of, tariff of 1879,314 ; evils arising out of, 328, 334; and campaign contributions, 333 ; of Liberals, 333, 364; attacked by Cartwright, 368,375 ; hostility of Liberals to, 370; attacked by Laurier, 372 ; and economic independence of Canada, 421

National Policy League, 219

National Policy Tariff of 1879,8 , 174 ; and protection to farmers, 16 ; cost of, 31

Navigation Laws, British, repealed, 62 ; and New Brunswick, 83

New Brunswick, 12; and reciprocity, 82, 87, 117 ; trade depression in 1848, $n .83$; and cotton manufacturing, 168 ; and duties on coal and flour, 274 ; Macdonald attempts to deceive, 312

Newcastle, Duke of, Colonial Secretary, 243; and Sheffield memorial, 246

New Englaud, and Canadian duties, 140

New Glasgow, 405

Newspapers, control of, 38, 184 ; and the farmers, 451 ; Government control of, 458; Goldwin Smith ou control of, 459 ; as Government organs, 400

North American Review, article by Cartwright iu, 3 ; article on Tariff Commission, 433

Nova Scotia, 2, 4, 12; and coal industry, 26; and Dominiou Iron and Steel Company, 32; and reciprocity, 86 ; and cotton manufacturing, 168 ; and coal duty, 26I ; and Confederation, 262 ; and coal trade, 268; Macdonald attempts to deceive, 312 ; electioneering methods in, 312; and coal duty of 1879 , 320 ; and iron industry in 1879 , 324 ; and tariff revision of 1897 , 382 ; and bonuses to industries, 412 ; Steel Company, 438

Oil, duty on, 261

Oliver, Mr., M.P., 241

Ontario, 2 ; and reciprocity, 86 , 161,174 ; and cotton inanufacturing, 168; and duty on coal, 274 ; and bonuses to industries, 289, 410; and lumber regulations, 366

Ontario Farmers' Association, 18, $432,451,453$

Opposition, Conservative, uselessness of, 36,185

Oregon boundary, 45

Ottawa National Liberal Convention, 25, 368; resolutions adopted at, 370, 378; debate at, 371 ; Laurier's speech at, 372 ; Cartwright's speech at, 375 ; Gillmor's speech at, 437

Ottawa Programme, 178; reciprocity resolutions in, 179

Packing-cases, duty on, 216 Papermakers' trust, 348

Party ties, strength of, 460

Patent Laws Ameudment, 1903, 3 , 366 ; effect of, 410 ; terms of, 413

Faterson, Mr. William, 18 ; answers Tupper in 1878, 298 ; his speech at Ottawa Conveution, 379 ; excuses change of policy, 385 ; member of Tariff Commission, 431

"Patriot," Charlottetown, 283

Patronage, Government, 185

Pauncefote, Lord, 177 
Pearce, Senator, 91

Peel, Sir Robert, and free trade in England, 43; his proposals, in Canada, 47,51 ; complaints against, 63

Penman Company, 438

Peppermint, duty on essence of, in 1906, 321

Pierce, President Franklin, and fisheries question, 109 ; favours reciprocity, 114

Pig iron, duty on, in 1879,325

Pilot of Montreal, 213

Politics at Ottawa, character of, 457

Politics of business, dominant, 38

Population of Canada, 1901 and $1906, n .13$

Preference for Colonial imports, 52 ; and farmers and lumbermen, 56 ; pleas for, in 1846 , 60 ; come to an end, 62 ; Canada not waiting for, 393 ; Chamberlain's scheme for, 460 ; impracticability of scheme for, 465

Preference for Great Britain, indirect, 319 ; as a relief to consumers, 333 ; and protection to manufacturers, 363 ; Conservatives oppose, 367 ; review of movement for, 389 : and faroured-nation treaties, 393 ; fully in force, 395 ; first curtailment of, 397 ; manu. facturers' dislike of, 425 ; attacks on, before Tariff Commission, 439 ; commended by farmers, 443 ; curtailed in 1906-7, 464

Preferential tariff for Great Britain, 1 ; first enactment of, 25 ; its inroad on protection, 26 ; on salt, in 1870, 270; first suggested in 1876, 288 ; urged by Tupper, 295 ; not seriously considered in 1878,300 ; and safe-guarding of Canadian interests, 364 ; in 1897,387 ; terms of, 389 ; amendment to, 397 ; and German surtax, 415
Press Association, and paper trust, 349 ; and amendment of anti-trust law, 351

Prince Edward Island, and reciprocity, 86 ; and Confederation, 262

Privileged orders in Canada, 383

Procedure in House of Commons, 325

Prosperity in Canada, 29, 428

Protected interests, and politics of business, 34

Protection, geographical burden of, 12,14 ; and degeneration of Government, 184 ; first movement for, 198, 205 ; origin of modern movement for, 223 ; to find careers, 224 ; adopted in Canada, 259; debates on, in 1877, 290, 295

Protection to home industries, 1 , 2,4 ; increased in 1906,29 ; and politics of Canada, 30 ; cost of, 31, 39 ; Macdonald and, 275 ; increase of, by Liberals, 364

Protection in United States, less burdensome than in Canada, 11 ; weakness of, in 1853,117 ; revival of, 139 ; and immigration, 337

Protectionist pin-pricks, 130, 135 Protectionists, triumph of, in 1858, 233 ; never satisfied, 234

Protective system, and political corruption, $32,42,333,334$; and wage-earners, 336 ; cost of, to consumers, 342 ; and trusts, 352

Protests, British, against Canadian tariffs, 193, 237

Quebec, and annexation, 70 ; and reciprocity, 86,174

Radnor, Que., 405

Rails, Liberal Government contract for, 401 ; output of, in Canada, 403 ; duty imposed on, 403

Railways Subsidies Acts, 3 ; and 


\section{PROTECTION IN CANADA}

"Made in Canada" amendment, 27, 366, 399, 405

Reciprocity with United States, $45,61,66,88$; beginning of movement for, 79 ; forces making for, 81 ; foremost question in Canada, 82 ; and U.S. Congress, 90 ; negotiations for, 94 ; stages in movement for, 102 ; its importance to Canada, 108; favoured by U.S. Presidents, 113 ; progress in Congress in 1853, 115 ; establishment of, 120 ; advantages of, 121, 129 ; trade statistics under, 122 ; a pleasant tradition, 125 ; and the woollen trade, 126 ; discussed in Congress in 1862, 145 ; movement for renewal of, 159 ; U.S. demand inclusion of manufactures, 164 ; offered in tariff of 1870 , 165 ; perfunctory efforts for, 174,176 ; championed by Cartwright, 175 ; negotiations for, in 1891,177 ; resolutions for, in 1893, 178; and Maritime Provinces, 180 ; Liberals not sincere towards, 181,182 ; hopelessness of, 184 ; Canada eager for, 262 ; and tariff of 1870, 267 ; Macdonald urges, 306

Reciprocity, Treaty of, 1874, 165, 167,170 ; rejected by Senate, 172 ; terms of, 173

Red Parlour, 40, 224, 266, 310, $328,346,353,354,357,364$, 369,381

Redpath sugar refinery, and sugar duties, 241

Retaliation against U.S., urged in 1852, 214; again suggested, 307,425

Rice, duty on, 354

Ridout, 212

Robinson, Inspector-General, 188, 190

Rose, Attorney-General, defends soap duties, 230

Rubber combine, 351
Russell, Lord John, 154, 157, 194

Sacrifice market, 305, 318

St. Alban's raid, 149

St. Catherine's, Ont., 320

St. George, N.B., 444

St. Hyacinthe, Que., 444

St. John, N.B., 320, 419, 433, 444

St. John River, 117

St. Lawrence canals, 47 ; public debt for, 55 ; and reciprocity, $95,108,120$

St. Lawrence ports and free trade in 1846,46

Salt, duty on, in 1870,270 ; United States, manufacturers of, 304

Sarnia, Ont., 411

Sault Ste Marie, 28, 399, 400

Seigniorial system, 384

Senate, insigniticance of, 24 ; appointment to, 457

Sentimental preference, value of, 442

Seymour, Sir George, 110, 112

Sheffield and Galt's tariff, 243 ; protest from, in 1859,244 ; answered by Galt, 248

Sherman, Senator, 153

Shipping, Canadian, in 1846, 53

Shubrick, Commodore, 110, 112

Sifton, Mr. Clifford, Minister of the Interior, 402

Slaughter markets, 200, 231, 303, 318

Smith, Mr. Goldwin, on irritation in U.S., 129 ; on corruption, 315; "Canada and the Canadian Question," 355; on Government control of press, 458,459

Smuggling encouraged by tarif duties, 254

Spaulding of Buffalo, 145

Specialisation, plea for tariff assistance for, 440

"Stand patters," 428

Stanstead, Que., 293, 296

Stanwood, Mr. E., 117, 125, 139 
Starlight, seizure of the, 111

Steel rails, duty on, 28

Stockport, 444

"Story of a Government that Does Things," 410, 416

Stoves, demand for increase of duty on, 439

Strathcona, Lord, 409

Strike-breaking in Canada, 339

Sugar favoured in 1859, 237, 240

Sullivan, R. B., 198

Sumuer, Senator, 152

Sun of Toronto, 451 ; its estimate of cost of bounties, 454

Surtax on German imports, 27, 413 ; complaints of, 417 ; col. lections under, 418

Syduey, Cape Breton, 399, 400, 433

Tariff of abominations, 330

Tariff of 1847 , British protests against, 193

Tariff of 1849, duties in, 197

Tariff of 1853, 214

Tariff of 1856, 218

Tariff of 1858, duties in, 229

Tariff of 1859 , and need of revenue, 237 ; duties in, 238 ; report of Committee of Trade on, 253 ; Royal Assent to, 258

Tariff of 1866 , duties for revenue in, 263

Tariff of 1870 and duties on coal and cereals, 266 ; duties in, 267 ; and protection for farmers, 270

Tariff of 1874,282

Tariff of 1879, Tilley's speech on, 316 ; rates of duties in, 318 ; debate on, 335

Tariff of 1897,387 ; amendment to, 398

Tariff of 1906, and increase of prices, 5

Tariff Commission of 1894, secrecy of, 356

Tariff Commission of 1896,381

Tariff Commission of 1905-6, evidence before, 6 ; and trusts in Ontario, 8; and Canndian prosperity, 29 ; and reciprocity, 125; and auti-trust law, 352 ; and pleas for protection against Britain, 389 ; and German surtax, 417 ; composition of, 431 ; procedure and work of, 433 ; features of work of, 435 ; pleas before, 438 ; its attitude towards the preference, 446 ; and farmers' representations, 451

Tariff duties, who pays the, 5 ; rates of, in 1847,189 ; rates of, in Maritime Provinces, 204 ; rates on American imports in 1866,158 ; Newcastle, on who pays the, 247 ; difficulty of reducing, 256 ; and loyalty, 269 ; and export trade, 351

Tariff politics, selfishness of, 466 Tariff resolutions at Ottawa Convention, 370

Tariff revision of $1897,25,381$

Tariff revision of 1906-7, effect of, 28 ; agitation for, 396,422 ; no popular support for, 424 ; manufacturers' reasons for, 427 ; promised by Government, 427 ; Government foreshadows terms of, 428 ; and triumph of manufacturers, 462

Tariff revisions since 1879,461

Tariff wars, sufferers in, .160, 418 ; courtesy of, 414

Taschereau, Mr. Justice, 349

Tax exemptions, 11, 410

Taxation as a means of increasing wealth, 296

Taylor, James W., report on Elgin-Marcy Treaty, 137

Taylor, President, 95

Third Party, difficulty of forming, 185

Thompson, Sir John, 356

Thornton, Minister at Washing. ton, 165,170

Thorold, Ont., 168

Three Rivers, Que., 444, 445, 461 Tilley, Sir Leonard, 19, 272, 419 ; and tariff of 1873,276 ; and tariff of $1879,316,363$ 


\section{PROTECTION IN CANADA}

Times, London, announces coming of free trade, 45

Toombs of Georgia, 116

Toronto, trusts in, 7 ; and protection, 220 ; manufacturers' convention at, 288; Tariff Commission at, 431

Treaty of 1815,80

Trusts in Canada, 4 ; helped by tariff, 6,343 ; nnearthed in Toronto, 7 ; first development of, 8 ; and tariff schedules, 8 ; dependent on tariff, 30,344 ; laws to check, 343,347 ; a concomitant of protection, 352

Trusts in United States, 3

Tuck, Amos, 108

Tupper, Sir Charles, 25, 176, 186 ; and reciprocity, 182 ; his arguments for protection, 202, 297 ; and tariff of 1859,239 ; attacks Mackenzie Government, 287 ; advocates British pre. ference, 295 ; attacks anti-trust clause, 347 ; and campaign contributions, 355 ; attacks British preference, 393 ; opposes "Made in Canada" amendment, 400

Tussaud's, Madame, 186

United Empire Loyalists, 384

United Provinces, and reciprocity, 85,87

United States, Canadian relations with, 71 ; tariff friction with, 80 ; and reciprocity, 87,89 , 91,183 ; imports from, 97 ; opposition to Elgin-Marcy Treaty in, 141; grievances against Canada, 143; and irritation against England, 148; duties on imports from, 158, 318, 365 ; increase of imports from, 366

United States manufactures, superiority of, 253 ; protection against, 365
United States tariff, 2; and campaign contributions, 40 ; in 1846,81 ; and protection of labour, 337

Valleyfield, Que., 323, 442

Valuation of imports, 214

Van Buren, President, 148

Vancouver, 433

Vested interests under tariff, denied by Cartwright, 331

Victoria, B.C., 433

Wage-earners suffer from protection, 335

Wages, relation of, to prices, 340

Webster, and reciprocity, 100, 108,113 ; and fisheries ques. tion, 106

Whates, The New Nation, 9

Wheat, acreage of, $n .213$

Wholesale Grocers' Guild, 345

Willison, J. S., characterisation of Senate, 24

Wilson, Senator, 155

Windsor, Ont., 444

Winnipeg, and immigration, 15

Wire-rod mills and Liberal Government, 406

Witness, Montreal, 369 ; and tariff of 1906, 37

Wood, Andrew T., 279

Wood-pulp, and Dingley Tariff, 425 ; makers of, and Mr. Chamberlain, 461

Woollen industry, and British preference, 26,395 ; and reciprocity treaty, 126 ; beginnings of, 168 ; concessions to, in 1904,396

Wool manufacturers of U.S. Association of, 126

Young, John, 72, 213

Zollverein, an American, 131 ; British, proposed by $\mathrm{Mr}$. Chamberlain, 394 


\title{
THE UNREFORMED HOUSE OF COMMONS
}

PARLIAMENTARY REPRESENTATION

BEFORE 1832

\author{
BY \\ EDWARD PORRITT
}

ASSISTED BY

ANNIE G. PORRITT

Vol. I. England and Wales, pp. xxiv +622 and a Map. Vol. II. Scotland and Ireland, pp. xiv +584 and 2 Maps. Demy 8vo. Price 25s. net.

\section{CAMBRIDGE UNIVERSITY PRESS}

\section{Extract from Preface.}

These volumes are concerned with Parliamentary representation in England and Wales, in Scotland, and in Ireland before 1832. My aim has been to trace the changes that representatiou in all four countries underwent from the time that the House of Commons in England began to have a continuous existence until the Reform Act of 1832 . . . . In a word, I have attempted such a history of Parliamentary representation as would enable a student of constitutional development to realise what the representative system actually was when, in 1831, Grey, Russell, Althorp, and Brougham undertook the great work of Parliamentary Reform.

DAILY NEWS.-"Mr. Porritt's handsome volumes, representing many years of steady labour, will take their place among the classics of English Constitutional history. .. . It is impossible to praise too highly the thoroughness and completeness with which Mr. Porritt has accomplished his task. It would, indeed, be difficult to think of a topic connected with representation in reference to whicl these volumes do not provide all the requisite information."

Right Hon. Avoustine BirRell in CHRISTIAN WORLD.-- "So far from having produced a dry book, Mr. Porritt has produced one which, when carefully studied and noted, will make many political questions which, when stated in the arid language of party strife, are indescribably dull, unutterably mean and miserably commonplace, become lively and positively entertaining. Mr. Porritt although he writes gravely, as befits a scholar and the University Press, has succeeded in clothing the dry bones of Parliamentary history and making them live."

Professor C. Grant Robertson in ENGLISH HISTORICAL REVIEW."Mr. Porritt has placed at the disposal of all historical students, in two compact, lucidly written and admirably arranged volumes, results which, so far as I know, are not to be found in any other single treatise worked out with such detail, or so clearly put. 
In Three Volumes. 8vo. 21s. net each.

Vol. I. A to E. Vol. II. F to M. Vol. III. N to Z.

\section{DICTIONARY}

$\mathrm{OF}$

\section{POLITICAL ECONOMY}

EDITED BY

R. H. INGLIS PALGRAVE, F.R.S.

ECONOMIC JOURNAL.- "Its value is manifest; ample and trustworthy information, abundance of verified documents, bibliography of inappreciable value, it must be the vade mecum of him who wishes more knowledge."

STATIST.- "An excellent cyclopædia of all matters pertaining to political economy."

STANDARD.—"A financial work of more than ordinary importance. . . . The information has been well brought up to date. .. E Equally valuable to the student of finance or political economy and to the business community."

OBSERVER.—."Mr. Palgrave's extremely valuable work."

SCOTSMAN.- "Mr. Palgrave is to be congratulated on having brought together a vast amount of valuable material and arranged it in a fashion in which it will be readily accessible."

MACMILLAN AND CO., LTD., LONDON. 


\section{COMMERCIAL CLASS BOOKS.}

Edited by JAMES GOW, Litt.D.

Globe 8vo.

THE HISTORY OF COMMERCE IN EUROPE.

By H. De B. Gibrins, M.A. 3s. 6 d.

COMMERCIAL GEOGRAPHY.

By E. C. K. Gonner, M.A. 3s.

INTRODUCTION TO COMMERCIAL GERMAN.

By F. C. Sмrтh, B.A. 3s. 6d.

INTRODUCTION TO COMMERCIAL SPANISH.

By L. Delbos, M.A. 3s. 6d.

COMMERCIAL ARITHMETIC.

By S. JACKson, M.A. 3s. 6d.

A MANUAL OF BOOK-KEEPING. For the Use of Students. By J. Thornton. 7s. 6d.

COMMERCIAI LAW.

By J. E. C. Munro, LL.M. 3s. 6d.

MARINE INSURANCE.

By William Gow, M.A. 5s.

MACMILLAN AND CO., LTD., LONDON. 


\section{MACMILLAN AND CO.'S PUBLICATIONS.}

ON MUNICIPAL AND NATIONAL TRADING. By the Right Hon. Lord Avebury. 8vo. 2s. 6d.

FREE TRADE. By the Right Hon. Lord Avebury. Svo. 2s. 6 d.

PRINCIPLES OF ECONOMICS. By Professor Alfred Marshall, M.A. 8vo. Vol. I. 12s. 6 d. net.

PUBlic finanCE. By Professor C. F. Bastable. 8vo. 12s. 6d. net.

THE THEORY OF INTERNATIONAL TRADE, WITH SOME OF ITS APPLICATIONS TO ECONOMIC POLICY. By Professor C. F. Bastable. Crown 8vo. 3s. 6d. net.

PROTECTIVE AND PREFERENTIAL IMPORT DUTIES. By A. C. Pigou, M.A., F.S.S. Crown 8vo. 2s. 6d. net.

PRINCIPLES AND METHODS OF INDUSTRIAL PEACE. By A. C. PIGou, M.A., F.S.S. Crown 8 vo. 3s. 6d. net.

SPEECHES ON FREE TRADE. By RICHARD Cobden. 8vo. Sewed, 6d.

ON FREE TRADE. By C. B. ClaAkE. 8vo. Sewed, 6d. 


\section{MACMILLAN AND CO.'S PUBLICATIONS.}

THE DISTRIBUTION OF INCOME. By WILLIAM Sirart, M.A. Extra Crown 8vo. 5s. net.

THE RETURN TO PROTECTION. By WILLIAM Smart, M.A. Crown 8vo. 3s. 6d. net.

INTERNATIONAL COMMERCIAL POLICIES. With Special Reference to the United States. By Professor George Mygatt Fisk, Ph.D. Crown 8vo.

THE EVOLUTION OF MODERN MONEY. By William W. Carlile. Extra Crown 8vo. 7s. 6d. net.

THE NATURE AND NECESSITY OF INTEREST. By G. CASsei, D.Phil. 8vo. 6s. net.

A B C OF THE FOREIGN EXCHANGES. A Practical Guide. By George Clare. Crown 8 ro. 3s. net.

THE TRADE POLICY OF GREAT BRITAIN AND HER COLONIES SINCE 1860. By Carl Johannes Fuchs. Translated by Constanch H. M. Archibald. With Preface by J. Parker Smith. Extra Crown 8vo. 7s. 6d. net.

FREE TRADE A FAILURE FROM THE FIRST. By Thomas Penn Gaskell. With Diagrams. 8 vo. 2s. net.

MACMILLAN AND CO., LTD., LONDON. 
Works by Professor HUGO R. MEYER. GOVERNMENT REGULATION OF RAILWAY RATES

Extra Crown 8vo. 6s. 6d. net.

\section{MUNICIPAL OWNERSHIP IN GREAT BRITAIN}

Crown 8vo. 6s. 6d. net.

THE BRITISH STATE TELEGRAPHS

Extra Crown 8vo. 6s. 6d. net.

PUBLIC OWNERSHIP AND THE TELEPHONE IN GREAT BRITAIN

Extra Crown 8vo. 6s. 6d. net.

By B. H. MEYER, Ph.D.

RAILWAY LEGISLATION IN THE

UNITED STATES

Crown 8vo. 5s. net.

By HENRY S. HAINES.

RESTRICTIVE RAILWAY LEGISLATION

Crown 8 vo. 5s. net.

RAILWAY CORPORATIONS AS PUBLIC SERVANTS

Crown 8vo. 6s. 6d. net.

MACMILLAN AND CO., LTD., LONDON. 

HF

$$
\begin{aligned}
& 1763 \\
& P 6
\end{aligned}
$$




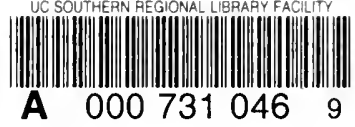


\%

4

\begin{tabular}{|l|lll}
\hline & & & \\
\hline
\end{tabular}

年

-

(19)

6.8.

$40 \%$ \%

4 4.

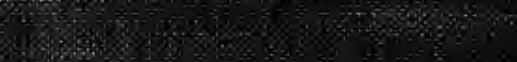

1.

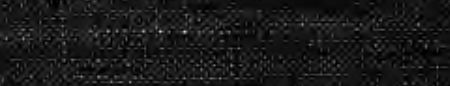

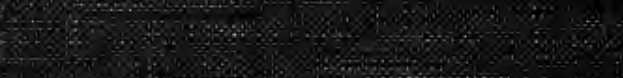

(4.

78)

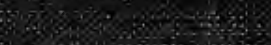

50 ,

\%

(2)

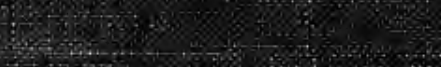

1.

20.3\%

(1)

D.

(5.2.

(T)

W

H.

(3)

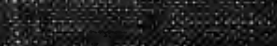

7. 30 \%

A.

20.6. 